\begin{abstract}
UNIVERSIDADE DE SÃO PAULO
INSTITUTO DE FÍSICA, INSTITUTO DE QUÍMICA, INSTITUTO DE BIOCIÊNCIAS E FACULDADE DE EDUCAÇÃO.

PROGRAMA DE PÓS-GRADUAÇÃO INTERUNIDADES EM ENSINO DE CIÊNCIAS (MODALIDADE FÍSICA)

EMOÇÕES E OS RITUAIS DE INTERAÇÃO COLOCADOS EM PRÁTICA POR PROFESSORES DE FÍSICA EM FORMAÇÃO DURANTE ABORDAGEM CONCEITUAL.
\end{abstract}

EDISON AMARO DA SILVA 
EDISON AMARO DA SILVA

\section{EMOÇÕES E OS RITUAIS DE INTERAÇÃO COLOCADOS EM PRÁTICA POR PROFESSORES DE FÍSICA EM FORMAÇÃO DURANTE ABORDAGEM CONCEITUAL.}

Versão corrigida

Dissertação apresentada ao Instituto de Física, ao Instituto de Química, ao Instituto de Biociências e à Faculdade de Educação da Universidade de São Paulo para obtenção do título de Mestre em Ensino de Ciências.

Orientador: Prof. Dr. Maurício Pietrocola 
Autorizo a reprodução e divulgação total ou parcial deste trabalho, por qualquer meio convencional ou eletrônico, para fins de estudo e pesquisa, desde que citada a fonte.

\section{FICHA CATALOGRÁFICA}

\section{Preparada pelo Serviço de Biblioteca e Informação} do Instituto de Física da Universidade de São Paulo

\section{Amaro, Edison}

Emoções e os rituais de interação colocados em prática por professores de física em formação durante abordagem conceitual. São Paulo, 2018.

Dissertação (Mestrado) - Universidade de São Paulo. Faculdade de Educação, Instituto de Física, Instituto de Química e Instituto de Biociências.

Orientador: Prof. Dr. Maurício Pietrocola.

Área de Concentração: Ensino de Física.

Unitermos: 1. Física - Estudo e ensino; 2. Emoções; 3. Formação de professores; 4. Rituais de interação; 5. Clima emocional. 


\section{AGRADECIMENTOS}

Aos meus pais, que sempre me apoiaram na constante busca pelo conhecimento e pela formação escolar e acadêmica.

Aos meus filhos, Beatriz e Adir, pela compreensão dos momentos que deixei de acompanhá-los para me dedicar à pesquisa e pelo apoio que me deram quando eu, acamado ou com mobilidade reduzida, estive afastado da pesquisa e precisei que eles cuidassem de mim.

Ao Maurício, pela orientação e as discussões tanto na disciplina "Ensino, Aprendizagem e Cultura Didática: Complexidade Escolar e Análise Multi-Lógica" quanto nas reuniões do grupo de pesquisa NUPIC - Núcleo de Pesquisas em Inovações Curriculares, da FEUSP.

Aos estagiários, pelo espírito de desprendimento, pela colaboração na pesquisa e pelas conversas de corredor.

À escola participante, à diretora e aos professores, pelo apoio dispendido na realização da pesquisa.

Aos colegas do mestrado e do doutorado, do NUPIC: Kellys, Tiago, Aline, Samuel, Carlos, Ernani, Juliana, Herbert, Gabriel, Lyon, e outros que participaram de algumas reuniões; pelas trocas e discussões que pudemos realizar com os estudos de referenciais teóricos tão novos no início para nós.

Aos voluntários leigos: Regina, Edevaldo, Jadir, Adriano, Lidiane, Diogo, Lucas, Beatriz, Mário, Denize, Bianca, Maurício, Luciana, Natália, Claudia, Edson, Marilize e Willyan.

À Universidade de São Paulo, pela sua estrutura e seus professores, e aos seus profissionais das bibliotecas, da secretaria do IFUSP e da FEUSP, que foram sempre prestativos no apoio acadêmico.

Ao SESI-SP pelo apoio na minha formação acadêmica. 
AMARO, Edison. Emoções e os rituais de interação colocados em prática por professore de física em formação durante abordagem conceitual. São Paulo: Instituto de Física, Universidade de São Paulo, 2018. p.136. Dissertação de Mestrado em Ensino de Ciências - Área de concentração: Ensino de Física.

\section{RESUMO}

Investigamos abordagens de conceitos de física em aulas da educação básica, por professores de física em formação, do ponto de vista microssociológico dos encontros face a face e o papel das emoções nesses encontros. Analisamos como essas interações face a face ocorrem em aulas de física durante abordagens de conceitos e os rituais de interação colocados em jogo pelos professores em formação. Desta forma, por meio de um estudo de casos, identificamos alguns rituais de interação que ocorrem durante o processo de ensino e aprendizagem em aulas de física, identificados pelo clima emocional da classe. Utilizando uma abordagem fenomenológica e uma metodologia reflexiva na qual, a partir das observações in loco, focamos nossa atenção nas abordagens conceituais em aulas de física e utilizamos o clima emocional como heurístico na busca de eventos salientes. Nossa investigação mostra que abordagens conceituais não são apenas processos de trocas intelectuais, mas interações face a face características dos encontros sociais e repletas de emoções que constituem a linguagem dessas interações e podem alterar o clima emocional da classe. Constatamos que o professor, consciente ou inconscientemente, coloca em ação rituais de interação de salvamento da fachada como o aprumo e o processo de evitação, podendo até mesmo subverter conceitos científicos para salvar a fachada, o que evidencia a importância de uma atitude reflexiva na prática docente, para que o professor realize escolhas mais conscientes como utilizar mais processos corretivos. Propomos também a inovação na utilização de medidas do clima emocional por leigos como heurístico para encontrar eventos salientes, fundamentados na perspectiva das emoções básicas, na possibilidade de compartilhamento interacional das emoções e na sua relação com o clima emocional da classe.

Palavras-chave: Formação de Professores - Rituais de Interação - Emoções - Clima Emocional. 
AMARO, Edison. Emotions and interaction rituals put into practice by the preservice physics teacher during the conceptual approach. São Paulo: Institute of Physics, University of São Paulo, 2018. p.136. Master's Dissertation in Science Teaching - Concentration area: Teaching of Physics.

\begin{abstract}
We investigate approaches of physics concepts in basic education classes, by preservice physics teachers, from the micro-sociological point of view of face-to-face encounters and the role of emotions in these encounters. We analyze how these faceto-face interactions occur in physics classes during concept approaches and the interaction rituals put in place by the teachers in formation. In this way, through a case study, we identify some rituals of interaction that occur during the teaching and learning process in physics classes, identified by the emotional climate of the class. Using a phenomenological approach and a reflexive methodology in which, based on in situ observations, we focus our attention on conceptual approaches in physics classrooms and use the emotional climate as heuristic in the search for salient events. Our research shows that conceptual approaches are not only processes of intellectual exchanges, but face-to-face interactions characteristic of social encounters and full of emotions that constitute the language of these interactions and can alter the emotional climate of the class. We found that the teacher, consciously or unconsciously, put into action the interaction of salvage interaction of the facade as the mastery and avoidance process, and may even subvert scientific concepts to save the facade, which highlights the importance of a reflexive attitude in practice the teacher to make more conscious choices such as using more corrective processes. We also propose innovation in the use of measures of the emotional climate by lay people as heuristic to find salient events based on the perspective of basic emotions, the possibility of interactional sharing of emotions and their relation to the emotional climate of the class.
\end{abstract}

Keywords: Preservice Teachers - Interactual Ritual - Emotions - Emotional Climate. 


\section{Sumário}

1. INTRODUÇÃO

2. UMA REVISÃO SOBRE A TEMÁTICA DAS EMOÇÕES NO ENSINO DE CIÊNCIAS 15

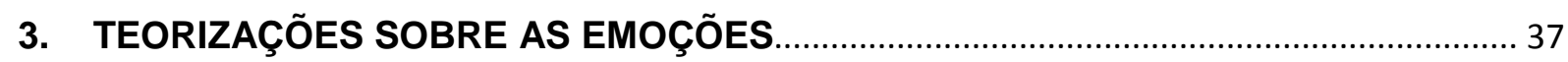

4. TEORIAS MICROSSOCIOLÓGICAS: AS INTERAÇÕES FACE A FACE ...................... 54

4.1. Rituais de Interação e Cadeias de Rituais: os encontros face a face......................... 59

4.2. O conceito de fachada e seus tipos básicos de salvamento ...................................... 61

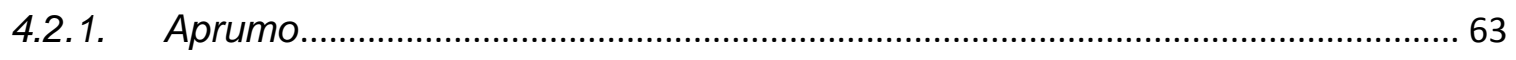

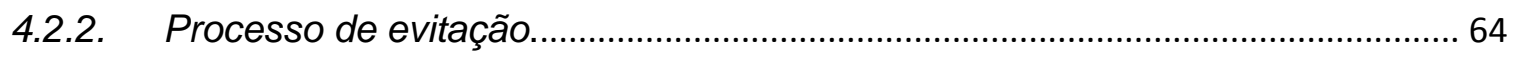

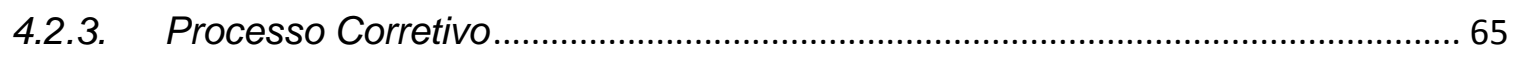

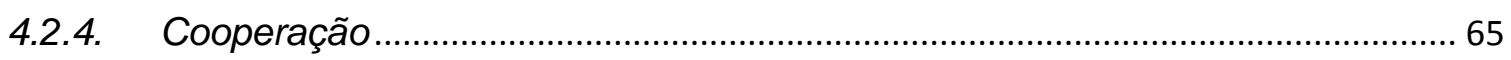

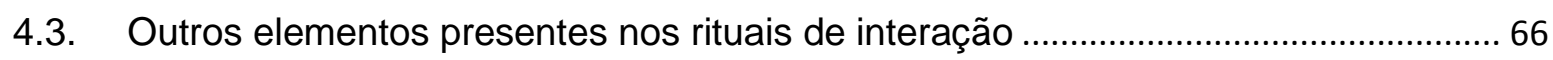

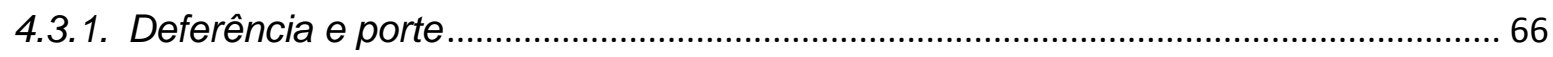

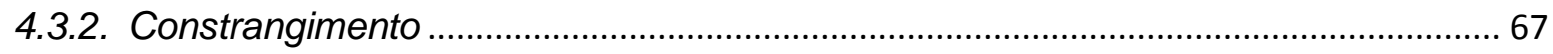

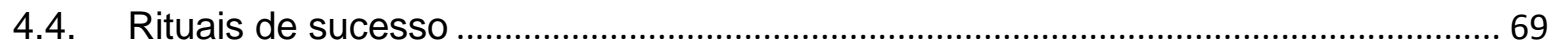

5. METODOLOGIA E CARACTERIZAÇÃO DA PESQUISA ............................................. 72

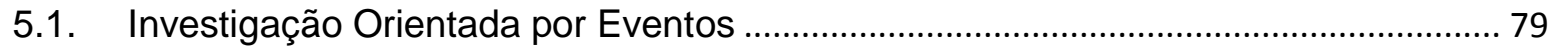

5.2. Método de verificação do clima emocional da aula ..................................................... 83

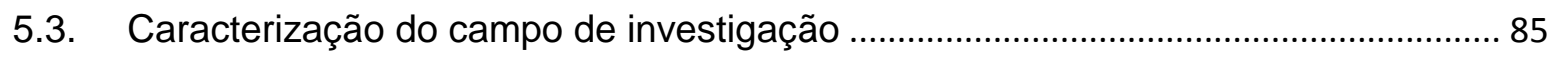

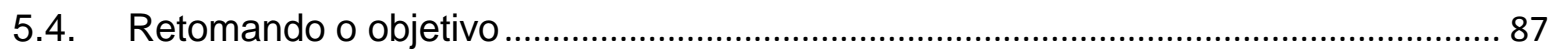

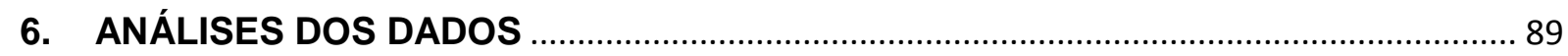

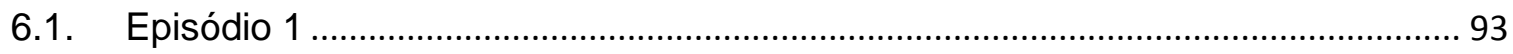

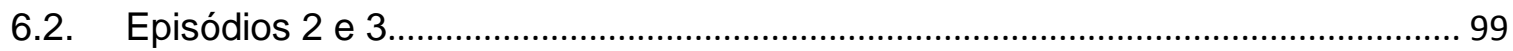

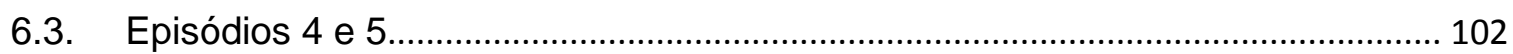

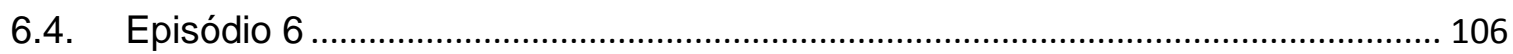

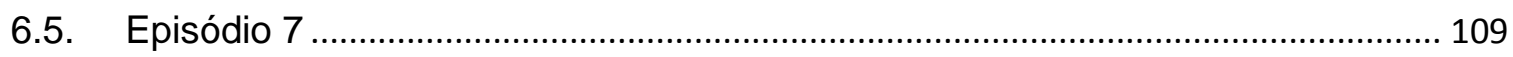

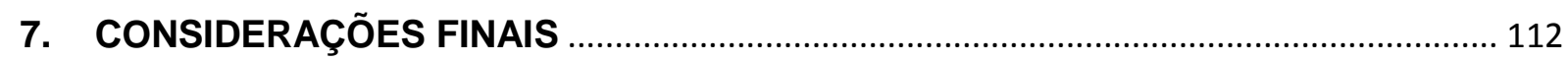

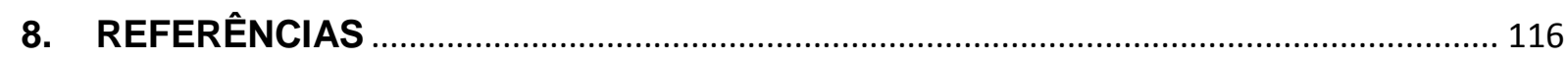

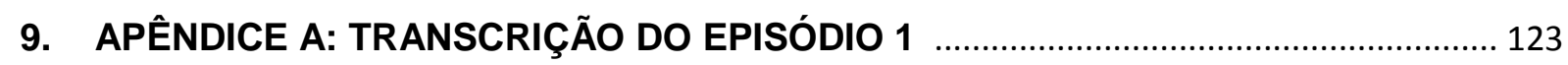

10. APÊNDICE B: TRANSCRIÇÃO DO EPISÓDIO 2 …............................................... 131

11. APÊNDICE C: TRANSCRIÇÃO DO EPISÓDIO 3.................................................. 133

12. APÊNDICE D: TRANSCRIÇÃO DO EPISÓDIO 4 .................................................... 137

13. APÊNDICE E: TRANSCRIÇÃO DO EPISÓDIO 5 ................................................. 141 


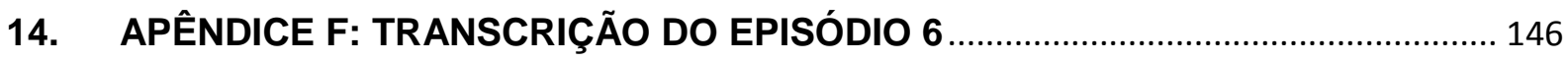

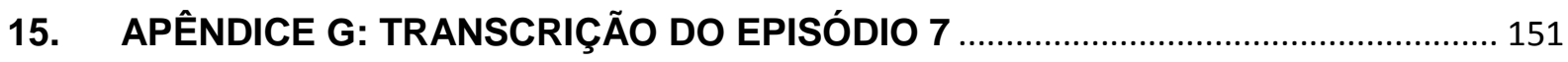

16. APÊNDICE H: INDICAÇÃO DO CLIMA EMOCIONAL DA CLASSE PELOS ALUNOS E POR PESSOAS EXTERNAS À AULA …..................................................... 157 
"Zuera enfatizar que essas emaçês funcionam cama jogadas e se encaixam tãa precisamente na lógica da joga ritual que seria difécil compreendê-las sem ele. De fata, as sentimentos espontaneamente expressos se encaixam no padrãa farmal da intercâmbia ritual de farma mais elegante da que as cancebidas conscientemente."

(Exing Golfman; 1982, p. 23, traduçäa nassa) 


\section{INTRODUÇÃO}

Durante os últimos 5 anos, participei de processos de acompanhamento e de formação continuada de professores na rede SESI-SP de Educação, na então área de Ciências da Natureza e Matemática.

Essa experiência difere da prática docente em vários aspectos, sobretudo por nos colocarmos a olhar para como são postos em prática todos os preceitos educacionais didáticos, pedagógicos, metodológicos ou de abordagens cognitivas e psicológicas. Talvez difira, principalmente, porque não somos nós que estamos nos vendo e por essa razão os atos dos outros são mais perceptíveis.

Algumas vezes tive a oportunidade de me deparar com situações que me direcionaram à seguinte reflexão: Como profissionais com boa formação acadêmica e dotados de experiência agem dessa maneira?!

Por exemplo, em certa situação, uma professora do Ensino Fundamental I, ensinando Matemática, levou um pacote de pirulitos e informou aos alunos que quem acertasse todos os exercícios receberia um pirulito ao final da aula. Poucos alunos acertaram todos os exercícios, vários erraram apenas um, porém a professora disse que todos receberiam um pirulito. Ao final da aula, a professora, conforme havia prometido, posicionou-se próximo à porta para entregá-los e complementou com as seguintes afirmações: Você ganhou e mereceu!, Você ganhou e não mereceu!, as frases eram proferidas pela professora de acordo com o desempenho do aluno; apesar de todos os conhecimentos que possui sobre pedagogia, didática e até mesmo psicologia no trato educacional, observa-se que a professora não refletiu acerca de sua ação.

Em outra situação, enquanto discutia junto à equipe de Ciências da Natureza e Matemática sobre problemas de baixo desempenho dos estudantes brasileiros em Matemática, o pouco interesse pelas disciplinadas de Ciências da Natureza e Matemática, como poderíamos fazer para aumentar esse desempenho na rede e a preparação dos professores desde as séries inicias do Ensino Fundamental, apontei que, em determinada aula de Matemática, os alunos demonstraram pouco interesse, baixo envolvimento e um nítido senso de difícil sobre o assunto ensinado, apesar de não ser um conteúdo acima do nível deles. 
Comentei que percebi muitas feições da professora que indicavam que ela transmitia aos alunos que o conteúdo ensinado por ela era ruim ou difícil, mas necessário (apesar de não ter dito isso com palavras para os alunos); isso eu percebera pelas expressões, tons de voz e posturas da professora, ou por mera intuição, não tanto por suas palavras. Meus colegas, formadores de professores de Matemática, contestaram e argumentaram que a professora havia feito tudo corretamente como já trabalhado em formações sobre a didática da Matemática. Apenas uma colega formadora ficou pensativa sobre o que eu havia dito e também teve dúvidas sobre essa possibilidade.

As trocas sociais que realizamos a todo momento fazem parte de nosso crescimento enquanto pessoas e também como profissionais, embora nem sempre sejam devidamente aproveitadas por nós nesse sentido.

Assim, estudar melhor essas trocas sociais no contexto da sala de aula em si mesmas, tornou-se um dos meus interesses. A partir dos encontros junto ao NUPICFEUSP pude conhecer alguns sociólogos e pesquisadores que trabalham na perspectiva microssociológica que podem subsidiar a investigação sobre a interação professor-aluno.

As pessoas com quem convivo no cotidiano já me ouviram proferir a seguinte expressão ao observar certas atitudes inesperadas de alguém: "O ser humano é bicho, não é gente!”. Durante as leituras dos sociólogos da tradição microssociológica me deparei com a frase de Erving Goffman que permite complementar o que costumo utilizar:

A natureza humana universal não é uma coisa muito humana. Ao adquiri-la, a pessoa se torna uma espécie de construto, criada não por propensões psíquicas internas, mas a partir de regras morais que são impressas nela externamente. (GOFFMAN, 1982; p.45, tradução nossa)

E esse bicho humano é essencialmente social e na sua forma de interagir com os outros tem as emoções como característica básica dessa interação, por isso precisamos estudá-las não apenas do ponto de vista psicológico, mas também das interações sociais.

Certamente, a abordagem microssociológica não exclui o aspecto psicológico, ao contrário, pode nos ajudar a compreender melhor o processo de interação social para subsidiar os aspectos psicológicos internos do indivíduo, algo importante para a formação do professor. 
Durante os quase quinze anos que estive em sala de aula, sempre tive uma postura muito centrada na aprendizagem da Física como algo que deveria ser o cerne do professor, como se aspectos emocionais não estivessem envolvidos no processo de aprender os conceitos da física. Quando trabalhei por dois anos com alunos de Educação de Jovens e Adultos, estive mais solto com relação a expressar emoções da convivência e com relação ao conceito físico que estava trabalhando. Alguns alunos confessaram perceber minha paixão pela física, por aquele conhecimento, como quando estava ensinando um conceito físico como atrito, ondas eletromagnéticas, ou funcionamento do micro-ondas, por exemplo.

Olhando hoje para minhas experiências em sala, esse período se destaca justamente porque não fui um professor tão frio, como alguns alunos (não aqueles) já mencionaram. Lembro-me de situações em que os alunos demostraram muito apreço, talvez como reflexo de minha postura que expressava mais emoções. Em certa situação, um aluno daquele período veio me agradecer pois agora ele entendia porque não podia colocar metais no micro-ondas, e antes não compreendia porque se colocava em um forno normal e não podia fazer o mesmo com o micro-ondas. Em outra situação, um senhor veio me dizer que sua esposa tinha pedido para me agradecer, pois, depois da aula que teve comigo, ele não mais utilizou talheres na frigideira de teflon. Essa mudança na rotina ocorreu depois que aprendeu sobre coeficientes de atrito e o problema de criar arranhões no teflon.

Talvez eu não compreendesse que mesmo quando era considerado frio, estava expressando alguma emoção, por minhas posturas, expressões e entonação das palavras.

E se, por um lado, o processo educacional é um ato social em si, nós costumamos esquecer dos aspectos emocionais envolvidos, do quanto nossas ações, escolhas, caminhos estão repletos de atos não racionais. Mas, que relações guardam as emoções com a razão? Há algo de emocional na razão? A razão pode dar conta de construir os caminhos da aprendizagem educacional? São questões muito gerais que por vezes me faço.

Esse ato social do processo educacional para a aprendizagem de conhecimentos, sobretudo no campo da Física, nem sempre costuma envolver (social ou emocionalmente) os estudantes em sua busca. 
E, apesar dos gostos, vontades, desejos existirem enquanto vontades próprias nos indivíduos, eles também se moldam ou são criados a partir da interação social. Então, por vezes me deparei com questões sobre o ensino da Física: por quê muitos alunos não gostam de Física? Como fazê-los gostar mais? É possível que eles se interessem mais por Física?

Se olharmos para outros países, sobretudo os orientais, a aprendizagem da Física e da Matemática entre os estudantes parece algo mais fruído, considerada mais natural naquelas culturas escolares, basta vermos os desempenhos dos países orientais nos exames internacionais em ciências da natureza e em matemática.

Durante nosso acompanhamento das atuações dos futuros professores nas salas de aulas, por vezes percebíamos que algo parecia ter acontecido com relação ao clima da classe, ao tom das falas dos alunos, ou a algo que aparentemente saiu do que os futuros professores esperavam em relação ao que estava sendo abordado e que os faziam aparentemente tentarem retomar o 'domínio da classe'.

Não tínhamos muito claro o que de fato estava acontecendo, mas, aparentemente as emoções do professor e da classe estavam passando por alterações mesmo quando o professor estava apenas abordando conceitos científicos; e passamos então a nos perguntar sobre o que poderia estar acontecendo nesses momentos.

Desses questionamentos, nos deparamos com uma problemática das emoções no processo de ensino e aprendizagem da Física e a partir dessas indagações sobre o processo de ensinar, e desejamos conhecer melhor sobre:

- As relações entre emoções vivenciadas no processo de ensinar um conceito de Física e a necessidade do professor em formação de ter o domínio da classe;

- Analisar as interações dos professores em formação nos momentos de abordagens de conceitos da Física nas aulas, com base em aspectos emocionais.

Buscamos então por uma revisão bibliográfica, que apresentamos no próximo tópico, para identificarmos se a questão das emoções no processo de ensino das Ciências da Natureza e da Matemática tem sido objeto de preocupação nas pesquisas mais atuais na área e com que enfoques. 
Dessa revisão, os artigos de Ritchie et al (2013), de Tobin et al (2013) e de Rinchen; Ritchie; Bellocchi (2016) nos chamaram atenção por abordarem as emoções do ponto de vista da microssociologia dos encontros face a face e ajudaram a delinear nosso problema de pesquisa, além de suscitar alguns enfoques metodológicos que utilizamos com uma inovação.

Sendo a emoção, como mostraremos mais à frente, uma linguagem e um constructo das interações sociais, buscamos estudar esses encontros sociais nos momentos de abordagens de conceitos de física por estagiários, futuros professores de física.

Nossa revisão bibliográfica nos levou à olhar para as emoções pelo viés microssociológico com o objetivo de analisar os Rituais de Interação (COLLINS, 2004; GOFFMAN, 1982) durante os momentos em que os futuros professores estavam abordando conhecimentos de física, para identificarmos o que estava em jogo na interação que poderia ter relação com a necessidade de ter o domínio da classe.

Por meio das emoções compartilhadas no processo educacional, quando os futuros professores estavam abordando conhecimentos da física, buscamos conhecer quais rituais de interação eles colocam em jogo enquanto estão ensinando.

Por isso, focamos nossa investigação no processo que ocorre quando um professor está colocando em prática uma abordagem de ensino ou simplesmente explicando um conceito físico. Isso poderá trazer informações para compreender porque professores muitas vezes não colocam em prática o que aprenderam e servir de base para a formação dos professores, tanto inicial quanto continuada.

Assim, nossa pesquisa visa ajudar a lançar luz sobre o papel das emoções no processo de ensino e aprendizagem da Física. Esperamos que esse trabalho possa ajudar professores e outros pesquisadores a compreenderem melhor o papel das emoções e a importância delas no ensino. Desejamos também que sirva de incentivo para outras pesquisas que objetivem estudar com mais profundidade o surgimento e as funções das emoções no ensino da Física.

Uma vez que o objetivo da formação didática de professores é que realizem inovações em suas práticas em comparação com a sua formação ambiente, tradicional, ao invés de simplesmente ensinarem como lhes ensinaram, é fundamental que os futuros professores e os formadores desses professores tenham uma 
compreensão do que acontece durante as abordagens conceituais em sala de aula, do ponto de vista dos encontros face a face. 


\section{UMA REVISÃO SOBRE A TEMÁTICA DAS EMOÇÕES NO ENSINO DE CIÊNCIAS}

As pesquisas sobre o Ensino de Ciências tiveram, na segunda metade do século passado, vários enfoques teóricos que exerceram papel importante na formação dos professores, visaram a melhoria de sua prática em sala de aula e até hoje influenciam as abordagens educacionais.

Algumas linhas de pesquisa no ensino de Ciências se tornaram predominantes, sobretudo as de cunho psicológico; umas mais fundamentadas nos aspectos cognitivos da aprendizagem como as influenciadas pelos estudos sobre os estágios do desenvolvimento cognitivo (PIAGET, 2007) ou pela busca de uma aprendizagem significativa (AUSUBEL, 1970) e no desenvolvimento de ferramentas como os mapas conceituais (NOVAK, 1991) e os diagramas V (GOWIN, 2005); outras mais baseadas no processo de interação social e na importância de criar contextos que aproximem os conhecimentos científicos do professor aos dos alunos (VYGOTSKY, 1984).

Outro enfoque que permeou as investigações no Ensino de Ciências, por vezes associado aos estudos piagetianos de construção do conhecimento, foi o da História da Ciência e de sua importância no ensino, também como forma de desenvolver o espírito científico (BACHELARD, 2002).

Uma grande e variada quantidade de pesquisas foram realizadas sobre esses enfoques e as formações inicial e continuada dos professores são constantemente alimentadas por essas pesquisas, que constituem um grande conjunto de contribuições para a formação dos professores, a compreensão sobre os processos cognitivos envolvidos no ensino e na aprendizagem de conceitos científicos, a importância da história da ciência para o ensino da Física, o papel do professor de Física como mediador do processo social de fazer compreender os conceitos científicos por meio da transposição didática, entre outras.

As metodologias de ensino para formação dos professores têm se fundamentado em grande parte nessas pesquisas acadêmicas e alimentado a expectativa dos formadores de que os professores utilizem tais conhecimentos nas práticas realizadas com seus alunos da educação básica.

Muitas dessas abordagens já fazem parte das propostas curriculares oficiais e do dia-a-dia das escolas (BRASIL, 1998; BRASIL, 2017). Mas, a despeito de já estarem difundidas como práticas desejáveis, tanto durante a formação inicial dos 
professores quanto na formação continuada, as pesquisas que investigam a sala de aula há muito têm mostrado uma grande diferença entre o idealizado pelos organizadores dos currículos ou pelos formadores e o realizado pelos professores. (CARVALHO; GIL PÉREZ, 1992).

O distanciamento entre o idealizado e o praticado pode ter tido relação com o fato dos legisladores brasileiros seguirem essas tendências: a cada mudança de governo, novas orientações foram implementadas visando a centralização; e, por não se voltarem para a realidade da educação brasileira (KRASILCHIK, 2000), a prática dos professores foi pouco modificada ou as pesquisas na área não chegaram a influenciar a prática docente. (VILLANI, 1982; PEDUZZI et al., 1992; CARVALHO e VANNUCHI, 1996; OSTERMANN e MOREIRA, 2001)

Rezende e Ostermann (2005), ao analisarem as pesquisas em ensino de Física de três décadas e relacioná-las com as necessidades apontados pelos professores, constataram a distância entre os resultados das pesquisas e a melhoria do ensino na educação básica. Dentre os mais variados problemas e necessidades, os pesquisadores chamam atenção para o viés cognitivista das pesquisas, que deixam de pesquisar sobre as atitudes desfavoráveis dos alunos para o processo educacional, deixando de enfatizar os aspectos afetivos relacionados à aprendizagem:

Os problemas relacionados ao comportamento do aluno, que traz desafios para o
professor como educador, não têm sido preocupação dos pesquisadores em ensino de
Física. Provavelmente, aspectos afetivos e sociais envolvidos nesse problema têm sido
negligenciados em decorrência da ênfase no aspecto cognitivo do
ensinoaprendizagem. (REZENDE; OSTERMANN, 2005, p.335)

Como conclusão de seu trabalho, os pesquisadores apontam como caminho para superar o desencontro entre a pesquisa e a prática ser necessário, além de intensificar as parcerias entre pesquisadores e professores da educação básica, delinear uma nova agenda para as pesquisas que conceba a pesquisa em ensino de Física como uma ciência humana aplicada, como já sugerido por Delizoicov (2004).

Assim, existe uma lacuna entre o idealizado e estudado pelas pesquisas acadêmicas e a sua prática nas salas de aulas. E os motivos para isso são ainda pouco conhecidos, mas parecem ter relação com vários aspectos. Dentre eles, destacamos o fato de, durante a vida escolar e acadêmica, os futuros professores já possuírem uma formação incidental ou formação ambiente sobre o que vem a ser professor que foi adquirida sem reflexão e como algo natural, óbvio, de sentido comum. (CARVALHO; GIL PÉREZ, 1992) 
Além disso, há também outro fator importante: a pouca atenção que tem sido dada aos aspectos afetivos e motivacionais na sala de aula. Por isso, a necessidade do professor em serviço ou em formação:

[...] conhecer a importância que na aprendizagem das Ciências - isto é, na construção dos conhecimentos científicos - tem o clima da aula, as expectativas do professor, seu compromisso pessoal com o progresso do aluno, etc. (CARVALHO; GIL PÉREZ; 1992. p.249)

Apesar de já ter sido apontada a importância de considerar o clima da aula ${ }^{1}$, este não tem sido levado em consideração nas pesquisas em ensino de Física, apesar de já fazer parte de estudos em psicologia educacional. (MARHUENDA et al., 2004; MARTINS, 2014).

Acreditamos que, em parte, essa ausência se deva à falta de uma base teórica para o entendimento do que poderia ser considerado clima da aula e, como aparentemente ele se relaciona com as emoções, a falta de um campo conceitual que estudasse as emoções durante as interações em sala de aula, ou que tomasse a emoção e o clima da aula como intrínsecos aos encontros sociais que são as aulas; além, da tendência das pesquisas em ensino de Física historicamente focarem mais nos aspectos cognitivos. ${ }^{2}$

Monteiro e Gaspar (2007) realizaram um dos raros trabalhos brasileiros na área de ensino de física que buscou enfocar os aspectos emocionais. À luz da teoria de Vygotsky, buscaram estudar as interações sociais bem como as emoções desencadeadas nesse processo, estabelecidas por uma professora e seus alunos ao trabalhar conceitos físicos de equilíbrio de um ponto material e de um ponto extenso.

Essa pesquisa constatou que as emoções positivas, capazes de envolver os alunos e sustentar interações sociais profícuas para a aprendizagem, são definidas

\footnotetext{
1 Clima da aula (ou clima da sala de aula) é um conceito difícil de ser encontrado na literatura brasileira. Entretanto, existem alguns trabalhos em psicologia e educação, principalmente em países de língua espanhola e em Portugal, que buscam estudar o clima da sala de aula, como Martins (2014) que estudou a sala de aula com essa abordagem, buscando identificar o clima positivo ou clima negativo da aula na fala dos alunos; Ricardo et al (2012) que buscaram identificar relações entre o clima da aula e a motivação dos alunos para a aprendizagem da matemática e López et al (2012) que investigaram o clima da aula e sua relação com a convivência entre os alunos e a ocorrência de bullying no ambiente escolar.

${ }^{2}$ Clima Emocional e Clima Emocional da Aula são conceitos mais delimitados do que clima da aula. Abordaremos melhor esse conceito ao longo do trabalho, explicando sua acepção.
} 
em dois momentos importantes em sala de aula, para os quais o professor deve estar atento e consciente: a definição da situação e a mediação semiótica.

Apesar das poucas pesquisas brasileiras sobre o papel das emoções no ensino das ciências, e em especial no ensino da física; nos últimos anos, no entanto, a quantidade de pesquisas que procuram investigar a motivação dos alunos, o clima emocional da aula ${ }^{3}$ e as emoções em geral tanto dos professores quanto dos alunos, tem aumentado consideravelmente em periódicos internacionais.

Uma busca no banco de dados ERIC (Education Resources Information Center) utilizando os verbetes 'teacher, 'emotions e 'science', e com filtros '2008' e 'Journal Articles', apresenta 119 trabalhos de artigos acadêmicos, dos últimos dez anos (desde 2008). Se fizermos a mesma pesquisa, substituindo 'teacher' por 'student', encontramos praticamente o dobro de trabalhos, 225. No primeiro caso, dos 119 trabalhos, 65 foram publicados nos últimos cinco anos; no segundo caso, 111 para os últimos 5 anos, como mostra o histograma abaixo. Dessa forma, é perceptível como as pesquisas sobre o ensino das ciências têm se voltado para considerar e compreender os aspectos emocionais na sala de aula.

Figura 1 - Gráficos comparativos de artigos sobre pesquisas envolvendo emoções no ensino de ciências por períodos (últimos 10 anos, últimos 5 anos e último ano), para professor e para aluno.

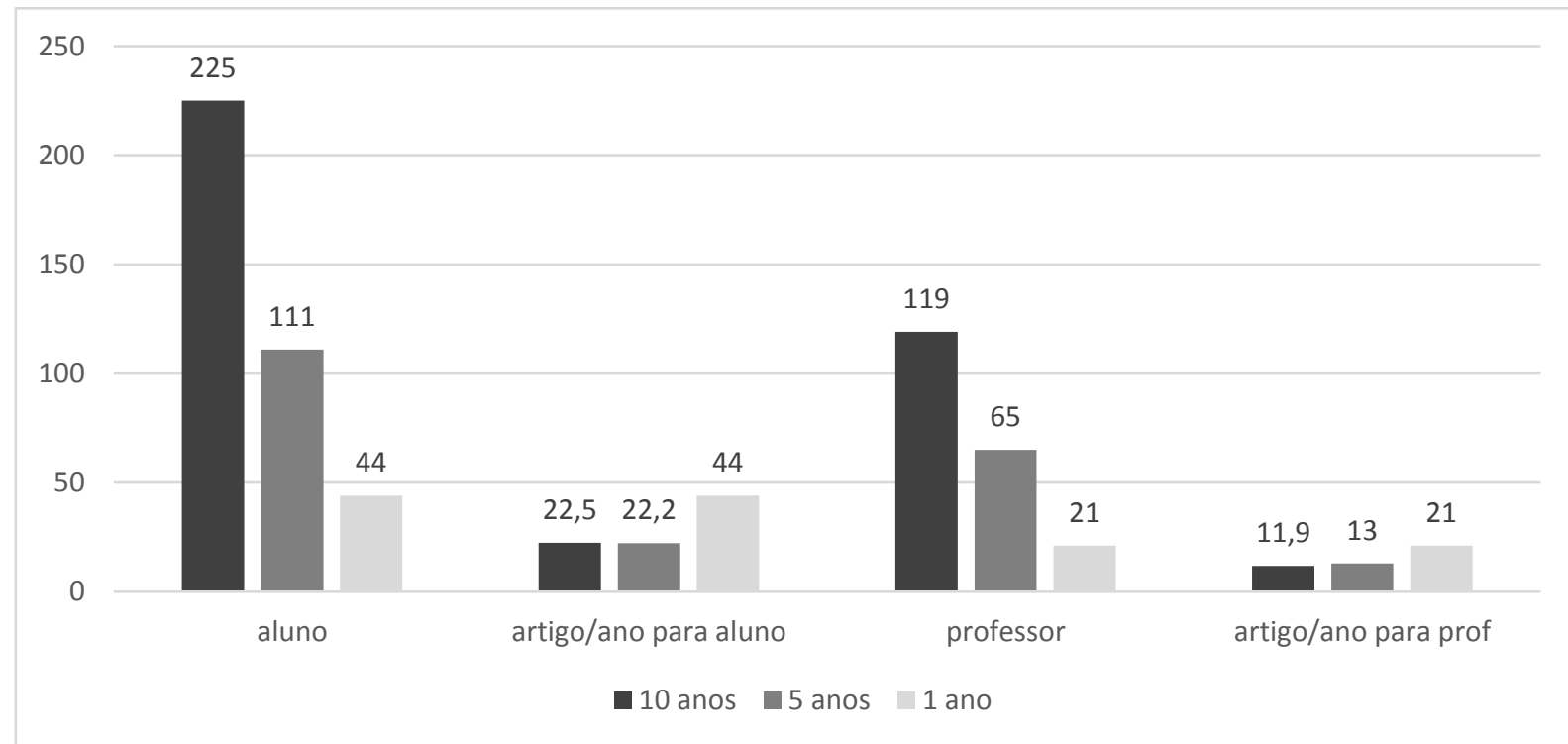

Fonte: ERIC - Education Resources Information Center. Institute of Educations Science. Dez., 2016.

\footnotetext{
${ }^{3}$ Evans et al. (2009) apud Bellochi; Ritchie; Tobin; Sandhu; Sandhu (2013), criticando a pouca atenção dada nas pesquisas acadêmicas para o clima emocional da classe, buscam uma caracterização para esse conceito, que considera a importância da interação entre o professor e os alunos e se fundamentam na teoria microssociológica de Randall Collins, que considera as emoções como a cola que une a sociedade e a aborda de um ponto de vista sociológico.
} 
A partir desse levantamento, fizemos um filtro pelos autores em que haviam mais expressividade pelo número total de trabalhos (com pelo menos 2 artigos sobre essa temática), e cuja leitura nos levou ao agrupamento mostrado na Tabela 1.

Tabela 1 - Agrupamento da revisão bibliográfica por autores em ensino de ciências com pelo menos duas publicações com a temática das emoções, nos últimos dez anos.

\begin{tabular}{|c|c|c|c|c|}
\hline Grupo 1 & Grupo 2 & Grupo 3 & Grupo 4 & Outros \\
\hline Ritchie, Stephen (7) & Randler, Chistoph (6) & Brigido, Maria (3) & Bartley, Anthony (2) & Akerson, Valarie L (2) \\
\hline Tobin, Kenneth (6) & Hummel, Eberhard (3) & Mellado, Vicente (3) & Melville, Wayne (2) & Fleer, Marilyn (2) \\
\hline Bellocchi, Alberto (5) & Wüst-Ackermann, Peter (3) & Bermejo, M. Luisa (2) & Outros autores - [6] & Milne, Catherine $(2) *$ \\
\hline Sandhu, Maryam (4) & Bogner, Franz X. (2) & Borrachero, Ana Belen (2) & & \multirow{2}{*}{$\begin{array}{l}\text { "o primeiro trabalho foi na } \\
\text { linha do } \mathrm{G1}\end{array}$} \\
\hline King, Donna (3) & Demirhan, Eda (2) & Costillo, Emilio (2) & & \\
\hline Roth, Wolff-Michael (3) & Glaser-Zikuda, Michaela (2) & Outros autores - [3] & & \\
\hline Sandhu, Satwant (2) & Outros autores - [14] & & & \\
\hline \multicolumn{5}{|l|}{ Outros autores - [11] } \\
\hline $\begin{array}{l}\text { - Emoções dos alunos e/ou dos } \\
\text { professores enquanto } \\
\text { participantes de interação social; } \\
\text { - Energia Emocional; } \\
\text { - Clima Emocional; } \\
\text { - Rituais de Interação; } \\
\text { - Diálogos Cogenerativos; } \\
\text { - Mindfullness; } \\
\text { - Metacognição }\end{array}$ & $\begin{array}{l}\text { - Emoç̃̃es dos alunos (medo, nojo, } \\
\text { ansiedade, etc) durante dissecação; } \\
\text { - Emoções suscitadas com relação às } \\
\text { questões ecológicas ou } \\
\text { socioambientais, como mudança } \\
\text { climática, riscos ambientais, } \\
\text { escassez de água, etc; } \\
\text { - Comparação entre emoções dos } \\
\text { alunos durante realização de uma } \\
\text { atividade prática de laboratório ou } \\
\text { em sala de aula; } \\
\text { - Emoções sentidas pelos alunos } \\
\text { durante passeio a zoológico, } \\
\text { aquário, etc. }\end{array}$ & \begin{tabular}{|l|} 
- Emoç̃̃es dos professores com relação ao \\
que irão enfrentar (sobretudo os \\
professores de educação infantil com \\
relação ao ensino de ciências) \\
- Comparação entre diferenças emocionais \\
no ensino de "ciências naturais" (Biologia \\
e Geologia) e as "ciências duras" (Física e \\
Química) \\
- As crenças de futuros professores sobre \\
sua "auto-eficácia" (capacidade de \\
enfrentar os desafios que virão) \\
- Diferenças dos gêneros com relação às \\
emoções.
\end{tabular} & $\begin{array}{l}\text { - Identidade evolutiva dos } \\
\text { professores e consciência de suas } \\
\text { emoções; } \\
\text { - Consciência dos aspectos } \\
\text { emocionais no ensino; } \\
\text { - Análise das emoções dos } \\
\text { professores em situações didáticas } \\
\text { como ensino investigativo e outros; } \\
\text { - Importância de o professor refletir } \\
\text { sobre suas frustrações e suas } \\
\text { emoções, metacognição; } \\
\text { - Influencias de fatores afetivos } \\
\text { (crenças, atitudes e emoções) no } \\
\text { ensino e na aprendizagem. }\end{array}$ & $\begin{array}{l}\text { - Emoç̃̃es declaradas dos } \\
\text { futuros professores com } \\
\text { relação a prática de } \\
\text { determina metodologia de } \\
\text { ensino; } \\
\text { - Importância que o } \\
\text { professor atribui às emoç̃̃es } \\
\text { no ensino; } \\
\text { - Importância que } \\
\text { estudantes da área da saúde } \\
\text { dão para as emoções } \\
\text { daqueles que serão seus } \\
\text { pacientes; } \\
\text { - Emoções ao realizar } \\
\text { estudos em plataformas } \\
\text { online; } \\
\text { - Percepção dos alunos sobre } \\
\text { apoio emocional pelo } \\
\text { professor. }\end{array}$ \\
\hline
\end{tabular}

Base: ERIC - dezembro 2016.

Dentre os trabalhos dessa amostra, Randler et al. (2016) investigam emoções (medo, nojo, ansiedade, etc.) dos alunos, futuros professores de Biologia, em situações de aulas que abordavam a dissecação de peixes, e compararam dois grupos: um que, antes da dissecação em sala de aula, assistiu a um vídeo sobre dissecação e outro que assistiu a um vídeo sobre a vida dos peixes. Os autores constataram que o grupo que assistiu ao vídeo de dissecação teve aumento tanto de emoções positivas e do senso de autoeficácia ${ }^{4}$ (sentimento de estar preparo para os

\footnotetext{
4 O conceito de autoeficácia há muito tem sido estudado no campo das pesquisas em educação e psicologia da educação (BZUNECK, 2000) e diz respeito àquilo que "determinará se uma pessoa irá apresentar comportamentos com os quais enfrente situações difíceis, envide esforços correspondentes e, a despeito de quaisquer obstáculos ou condições adversas, persista em seus propósitos, ou seja, suas convicções de que tem capacidade de executar os comportamentos exigidos para atingir os resultados pretendidos, e sem desistir no percurso." (BZUNECK, 2000; p.2) O conceito de autoeficácia foi bastante estudado por Bandura (1977) para traçar o self dos indivíduos no contexto das suas mudanças de comportamento.
} 
desafios), quanto de emoções negativas (ansiedade). Já o outro grupo não teve nenhuma alteração entre o pré-teste e o pós-teste.

Franke e Bogner (2013) investigaram as emoções situacionais (interesse, bemestar e ansiedade) vivenciadas por 291 alunos do ensino médio durante aula de experimentos de tecnologia genética. Divididos em dois grupos, um deles foi confrontado com as concepções alternativas de seus pares sobre questões centrais e processos de tecnologia genética e o outro não teve esse esclarecimento prévio. Os alunos do primeiro grupo sentiram melhor bem-estar, trabalharam com interesse nas aulas experimentais e obtiveram pontuações significativamente maiores nos testes cognitivos. Portanto, os autores concluíram que é aconselhável elucidar as concepções alternativas dos alunos e usar essa estratégia em uma ampla variedade de conteúdos didáticos. Ao optar por essa estratégia, os professores podem ajudar a criar um ambiente de sala de aula onde os alunos se sentem seguros e confiantes.

Em um estudo com alunos suecos de todos os níveis escolares, Ojala (2012) investigou como eles lidam com as emoções suscitadas ao tratar temas como a seriedade e a complexidade de problemas globais relativos às mudanças climáticas. A autora identificou várias estratégias de enfrentamento utilizadas pelos estudantes, por exemplo: enfatizando a gravidade da mudança climática, criando distanciamento, estresse físico, reavaliação positiva, confiança em diferentes atores sociais, enfrentamento focado em problemas e esperança existencial. Constatou também que as crianças menores usaram menos enfrentamento focado em problemas e maior distanciamento para lidar com a preocupação do que os grupos mais velhos. Com relação às esperanças, as crianças pequenas usaram uma reavaliação menos positiva. Elas depositaram a confiança nos investigadores e consideraram que o desenvolvimento tecnológico estava em um nível mais elevado do que aquele considerado pelos grupos mais velhos.

Bonderup Dohn (2011) investigou como o interesse situacional dos alunos do ensino médio foi desencadeado durante uma excursão a um aquário. A pesquisa foi conduzida como um estudo de caso para fornecer uma investigação indutiva e exploratória de como o interesse situacional emergiu durante a viagem de campo. Os resultados mostraram que a visita ao aquário provocou um grande interesse situacional entre os alunos e levou a emoções positivas em relação ao tema. Cinco variáveis situacionais desencadearam o interesse dos alunos: envolvimento social, 'pôr a mão na massa', surpresa, novidade e aquisição de conhecimento. Como as 
variáveis estão em grande parte sob o controle do professor e/ou dos funcionários do aquário, o autor sugere que elas sejam consideradas e avaliadas antes da visita.

Esses trabalhos demonstram um enfoque nas emoções dos estudantes (medo, nojo, ansiedade, surpresa, etc.) em relação a determinado tema ou prática educacional. Dessa forma, percebemos uma forte valorização dos aspectos emocionais que os alunos sentem ou vivenciam. Esses trabalhos incorporam a questão das emoções dos alunos nas pesquisas na área de ciências.

Estudos relacionados às emoções dos professores têm surgido também, embora em menor número que os relacionados às emoções dos estudantes. Brigido et al. (2013) investigaram as conviç̧ões dos futuros professores do ensino primário sobre suas capacidades de ensinar, considerando, em particular, a relação com as emoções que esperam experimentar como futuros professores de ciências, diferenciando quando ensinarão os conteúdos das ciências da natureza (Biologia e Geologia) e os das 'ciências duras' (Física e Química). Os resultados mostraram que eles têm principalmente emoções positivas para as ciências da natureza e negativas para as 'ciências mais duras'. As crenças dos professores sobre a autoeficácia estão significativamente relacionadas às suas emoções sobre o seu trabalho futuro com o ensino das 'ciências duras'. E o aumento da autoeficácia foi mais significativamente correlacionado com o aumento das emoções positivas e diminuição das emoções negativas para Física e Química.

Borrachero et al. (2013) investigaram as emoções dos futuros professores de Física e seu senso de autoeficácia (crença nas suas capacidades). Constataram que em geral os professores se sentem preparados para ensinar os conteúdos de Física. No entanto, os autores também identificaram que os professores que tinham crenças positivas sobre sua autoeficácia também experimentaram emoções positivas quando lecionaram física no ensino médio e os que tinham crenças negativas com relação à sua autoeficácia experimentaram emoções negativas durante suas práticas em salas de aula. Dessa forma, Borrachero et al. (2013) consideram que é essencial implementar um programa de apoio e acompanhamento das práticas pedagógicas dos professores, que promovam a conscientização, o aumento da capacidade de autorregulação e mudanças de atitudes, de crenças e das emoções negativas sobre a ciência - especificamente a Física - e sua aprendizagem. 
Em outro trabalho, Borrachero et al. (2014) investigaram as emoções de futuros professores de Geologia, Biologia, Física e Química ao ensinarem suas matérias, diferenciando-os por gênero. Constataram que os futuros professores do sexo masculino relataram mais emoções positivas do que os do sexo feminino. E o relato de emoções negativas por elas é maior para Geologia, Física e Química. Muitos desses futuros professores, especialmente as mulheres, declaram-se emocionalmente vulneráveis, uma vez que se descrevem como tendo emoções negativas mais fortes. Os autores apontam a importância de proporcionar aos futuros professores do ensino secundário um programa de apoio e acompanhamento durante a sua prática de ensino a fim de fomentar a consciência das suas emoções em relação à ciência e para com a sua aprendizagem, objetivando o aumento de suas capacidades de autorregulação e controle para mudar as emoções negativas, bem como consolidar hábitos saudáveis.

Outros trabalhos buscaram compreender as emoções do professor do ponto de vista do equilíbrio emocional e sua relação com os discursos. Melville e Bartley (2013), utilizando uma metodologia narrativa através dos discursos e das situações de trabalho de três professores e de suas respostas emocionais, investigaram o trabalho desses educadores buscando identificar o que Ihes permitiu desafiar o discurso contemporâneo da educação científica. Os pesquisadores descreveram como a evolução das identidades dos professores foram constituídas através de suas respostas aos discursos, situações de seu trabalho e das suas respostas emocionais a essas experiências. Ao realizarem uma análise foucaultiana ${ }^{5}$, os autores identificaram três importantes conclusões: a necessidade ou o desenvolvimento de um ambiente adequado é que faz o professor imergir no discurso, permitindo e apoiando ativamente práticas de sala de aula às quais desafiam o discurso contemporâneo e uma componente chave de tal discurso é a consciência dos aspectos emocionais do ensino; o currículo mandatado tem poder para legitimar, para os professores, discursos que desafiam o discurso contemporâneo; os professores, isoladamente, podem não ter a força necessária para estabelecerem ambientes

\footnotetext{
5 Os autores analisaram os discursos dos professores e utilizam a palavra 'discurso' em sentido foucaultiano: estrutura dos discursos, construção e constituição, percepção da realidade (Fairclough, 1992 - citação dos autores). No sentido foucaultiano (Michel Foucault, filósofo e sociólogo francês) os discursos também estão intimamente ligados com as questões de poder, de inclusão e de exclusão.
} 
discursivos que capitalizem plenamente sua capacidade de influência dentro da estrutura do ensino da ciência.

Dreon e McDonald (2012) demonstraram a influência que os fatores afetivos têm sobre a capacidade de dois professores iniciantes para implementarem a pedagogia do ensino por investigação. Ao verificarem o comprometimento emocional dos professores com o trabalho, utilizando essa abordagem didática em suas práticas, os autores constataram que, por meio das trocas entre os colegas, por meio de diálogos, blogs, etc. os professores se mostravam emocionalmente envolvidos. A ansiedade emergiu como a emoção que mais impactou nos participantes. Ela surgiu de seus sentimentos com relação a autoeficácia (confiança em seu êxito ao ensinar), da imprevisibilidade das atividades de investigação (fruto de crenças de controle) e de como eles percebem como seus alunos os veem (identidade de professor).

Essas pesquisas focadas nos professores, as quais visaram conhecer com mais profundidade o estado emocional do professor, enquanto característica da sua estrutura psicológica e do seu senso de autoeficácia, não são tão abundantes quanto as que investigam aspectos emocionais dos alunos, mas também vêm crescendo nos últimos anos, como mostramos no gráfico da página 17.

Dentre as pesquisas que abordam as emoções, um grupo de pesquisas têm se destacado nos últimos anos e chamaram nossa atenção. São pesquisas que consideram as emoções dos professores ou dos alunos enquanto participantes de um encontro social, não apenas com sua psique.

Esses trabalhos consideram a emoção como uma resposta social momentânea, fruto dos encontros sociais em microescala e não apenas como um estado psicológico interior.

King et al. (2015) exploram as emoções positivas de alunos de Ciências do 8o ano durante abordagem de uma unidade sobre energia por meio de vídeos de aulas e de entrevistas, diário das emoções (escritos no final das atividades), realizadas com o propósito de observar as emoções individuais dos alunos. Em uma perspectiva fundada na sociologia, constataram que, durante atividades de demonstração, os alunos experimentaram emoções de espanto e surpresa; durante atividade de laboratório, os alunos experimentavam emoções positivas intensas de felicidade/alegria; além disso, observaram que a atenção dos alunos era focada 
quando a emoção era positiva, mostrando um aspecto importante da relação entre emoções e os encontros face a face em sala de aula.

Ritchie et al. (2013), fazendo estudo de casos, investigaram até que ponto professores de Física iniciantes na Austrália perceberam que suas expectativas e suas experiências em sala de aula, durante implementação de ensino por investigação, produziram estados emocionais que interferiram em suas práticas de ensino.

Contrariando a retórica do medo de trabalhar com ensino por investigação, expressa por seus colegas mais velhos, três dos quatro professores ficaram surpresos com os resultados positivos de suas regências de classe por meio do ensino por investigação pela primeira vez.

Dois desses professores experimentaram emoções positivas de alta intensidade em resposta ao sucesso de seus alunos, superando os momentos que tiveram que lidar com a retórica do medo dos professores mais velhos.

Quando as ações e os resultados dos alunos não atendiam às expectativas dos professores, estes experimentaram a frustração, a raiva e o desapontamento, como previsto na teoria sociológica das emoções humanas de J. H. Turner. (Turner, 2007).

Os pesquisadores apontam que os resultados deste estudo fornecem insights sobre práticas eficazes de regência de classe que podem ser usadas durante as formações dos novos professores e também para formação continuada.

Rinchen; Ritchie; Bellocchi (2016) exploraram a percepção dos professores de Ciências em formação (especialização em Física e Matemática) sobre o CE (clima emocional) da sala de aula e as relações com a política macrossocial butanesa chamada Gross National Happiness; algo como 'Felicidade Interna Bruta', em analogia ao índice econômico PIB (Produto Interno Bruto) mundialmente utilizado pelas nações.

Os pesquisadores gravaram vídeos e áudios de episódios de ensino, realizaram entrevistas semiestruturadas e entrevistas de retomada estimulada, além das anotações nos seus diários de pesquisa. Os alunos realizaram registros de suas 
percepções sobre o CE (clima emocional) da aula em intervalos de 3 minutos utilizando a tecnologia de resposta do público por meio de clikers. ${ }^{6}$

A pesquisa identificou que o CE positivo foi percebido em atividades envolvendo apresentações dos alunos com uso de vídeos, momentos em que os professores estavam compartilhando situações de co-teaching (prática docente de ensino compartilhado) e nas situações em que ocorriam discussões interativas.

Por outro lado, nos momentos em que ocorriam palestras formais ou quando os apresentadores estavam despreparados, o CE diminuía.

Os pesquisadores constataram que as instituições educacionais do país têm o poder de fomentar ideais nacionais, tais como emoções coletivas positivas, se determinados tipos de ambientes de aprendizagem são criados através da aplicação de formas específicas de sequências interacionais que geram climas emocionais positivos.

Os autores identificaram também certas formas de abordagem que se distanciam desse modo de aprendizagem, posto que estas estão mais voltadas para produzir uma cultura de sala de aula que incorpore as forças normativas da cultura social dominante que, por exemplo, tem a submissão dos alunos aos professores como uma forma de respeito ao status social mais elevado que estes detêm.

Assim, quando os alunos quebraram este código cultural, por não darem mais respostas decoradas e por liderarem as sequências de aprendizagem em sala de aula, eles produziram estruturas que promoveram CE (clima emocional) positivo.

Embora os professores que participaram da pesquisa demonstraram ter consciência da importância das emoções no processo de ensino, os pesquisadores chamam atenção para o fato do ensino da Física e da Matemática no país não parece se preocupar muito com esse aspecto.

Os pesquisadores lembram que a qualidade da educação científica é fundamental para a construção do capital humano (especialmente no caso do Butão, onde a ciência e a tecnologia ainda estão em estágio rudimentar). E chamam atenção para o desafio que o país precisa enfrentar com relação à forma como a ciência é

\footnotetext{
${ }^{6}$ Clikers, ou personal response systems (sistemas pessoais de resposta), também conhecidos como response pulses, são aparelhos semelhantes a um controle remoto de TV, em geral com um teclado com alguns botões como "A", "B", "C", "D", "E" e de controle (avançar, retornar, enter, etc.), que permitem obter respostas rápidas de um público a questões de múltipla escolha. Além disso, por meio de software de controle do sistema, é possível visualizar dados estatísticos dos resultados obtidos. (Fonte: https://www.basico.unicamp.br/index.php/servicos/clickers. Acesso em: 30 jul. 2018)
} 
ensinada atualmente nas escolas e faculdades: em vez de seguir o currículo e os livros didáticos existentes, deveria buscar uma abordagem que valorizasse os pontos de vista dos alunos e que priorizasse a implementação de interações bem-sucedidas entre professores e alunos.

Em outra investigação, como parte de um trabalho maior sobre a transição de professores em formação para o exercício da profissão, Ritchie et al. (2011) realizaram um estudo de caso etnográfico que explorou como uma nova professora de ciências produziu e reproduziu rituais de interação com climas emocionais positivos com seus alunos em seu primeiro ano de ensino. Nesse estudo, por meio de análise das expressões faciais da professora, suas entonações e posturas de voz, demonstram como as interações dialógicas caracterizaram experiências positivas e satisfatórias para a professora, e como elas foram reproduzidas com sucesso em diferentes contextos de aulas.

Os pesquisadores focaram em dois eventos, com diferença de cinco meses entre os dois. A escolha foi feita porque ilustra como a professora passou por diferentes posições culturais para sua preparação para trabalhar as aulas de Ciências.

O primeiro evento refere-se a uma aula sobre a água, na qual os alunos estavam apresentando seus trabalhos em grupos, com a classe sentados em cadeiras formando um círculo na sala. Esse evento foi escolhido porque a professora apresentou vários pontos que esperava nas suas aulas de Ciências, e também porque foi um evento que havia sido citado como um exemplo de encontro potencialmente negativo emocionalmente - que estava em desacordo com suas expectativas de interações apropriadas para a sala de aula.

Em uma outra aula, sobre formação de montanhas, a qual os pesquisadores consideraram outro evento, foi caracterizada por energia emocional positiva, ao contrário da maioria dos outros momentos em que as interações não produziram energia emocional positiva. Sendo esse evento considerado como evento de sucesso (Collins, 2004).

Os pesquisadores usam o termo evento para referirem-se a um acontecimento, como a experiência da professora com um aluno ridicularizando as crenças de outro, que transformam estruturas significativamente (Sewell Jr, 2005, p.100) que pode começar com uma ruptura de algum tipo e, em seguida transformar em uma série em cascata de novas rupturas que resultarão em transformações estruturais - isto é, 
mudanças nos esquemas culturais, mudanças de recursos e o surgimento de novos modos de poder. (idem, ibdem, p.227)

Os autores chamam atenção para o fato de que enquanto Sewell Jr (2005) descreveu os poderosos desdobramentos emocionais associados à eventos históricos importantes, eventos de sala de aula que transformam estruturas subsequentes também provavelmente envolverão mudanças imprevisíveis nas emoções.

Após identificarem os eventos salientes, os pesquisadores assistiram e repetiram o vídeo em velocidade natural e, em seguida, quadro a quadro, transcreveram as interações e, quando relevante, anotaram e mediram as sobreposições e pausas de falas, observaram também as expressões faciais, os gestos e outros movimentos corporais dos participantes juntamente com as falas associadas.

Os autores observaram que a professora e seus alunos usaram a inclusão de comentários humorísticos para criar uma estrutura para interações dialógicas e para a efervescência do grupo. Durante essas interações bem-sucedidas os alunos usaram recursos como o humor compartilhados para satisfazer a professora e consequentemente se envolverem no conteúdo abordado na aula, reproduzindo cadeias de rituais de interação bem-sucedidos anteriormente (Collins, 2004). O humor compartilhado e a efervescência do grupo (risos) costumavam acompanhar essas interações bem-sucedidas. Além disso, algumas evidências mostraram que a professora nessas interações bem-sucedidas expressava vocalizações associadas a emoções positivas.

Os estudos sobre as emoções expressas pelos professores ou pelos alunos têm cada vez mais se valido da análise das expressões faciais durante os contatos sociais, uma vez que ao reportarem suas emoções as pessoas estão apenas relatando e, por vezes, a leitura posterior pode estar carregada pelo que já foi vivido nesse intervalo e assim representar não apenas as emoções que sentiram naquele momento mas o que acreditam ter sentido; além do que, as expressões faciais revelam muito das nossas emoções e, pelo menos as básicas, não parecem variar muito de uma cultura para outra. (EKMAN, Paul; In: TURNER, 2007, p.54) 
Estudos como os de Turner (2007) ${ }^{7}$ têm servido de base para a compreensão das emoções numa perspectiva social. Em um vasto estudo sobre as emoções e a organização social, Turner explorou como as formas genéricas de organização social e como a cultura inerente a todos os padrões de organização social causam o despertar não apenas das valências emocionais ao longo de um contínuo de positivo a negativo, mas também das emoções específicas. Desenvolveu uma explicação de como a valência e as emoções específicas despertam não apenas a dinâmica dos encontros presenciais, mas também as estruturas sociais de grande escala e suas culturas associadas:

[...] as emoções são uma das mais importantes forças sociais em nível micro, porque são elas que mantêm todos os níveis da realidade social juntos ou, no final, rompem encontros ou quebram mesoestruturas e macroestruturas. (TURNER, 2007; p.208, tradução nossa)

Tobin et al (2013), investigaram as expressões das emoções de uma professora em seu primeiro ano de docência ao mesmo tempo em que a ensinaram sobre as mudanças no corpo relacionadas a essas emoções.

Tobin et al (2013), fundamentados na ideia de Durkheim, de que "artefatos sociais são inscritos com EE (energia emocional) que reflete o clima emocional (CE) de eventos particulares" (Durkheim; 1995/1912, apud Tobin et al; 2013), utilizaram medidas do CE atribuídos pelos cinco pesquisadores para servir de heurístico para o encontro de eventos salientes. Cada pesquisador classificou independentemente 0 CE para 26 segmentos de três minutos, usando uma escala de cinco pontos: 5 , altamente positiva; 4 , positivo; 3 , neutro; 2 , negativo; e 1, altamente negativo, de uma aula de Ciências sobre flutuabilidade e Princípio de Arquimedes.

A seleção de eventos exigiu que os pesquisadores estendessem alguns segmentos, encurtassem outros e excluíssem eventos não salientes dentro dos segmentos. Em seguida, os pesquisadores fizeram microanálises centrados nos acontecimentos, verificando a conversação, a prosódia e outras análises não verbais. Os pesquisadores analisaram cada um dos três eventos escolhidos e tentaram aprender com os padrões e contradições dentro e entre os eventos, conscientes de que os eventos selecionados incorporaram diferenças no CE e que estavam associadas a mudanças na inclinação do gráfico CE em função do tempo.

${ }^{7}$ Nos próximos tópicos abordaremos mais detalhes da teoria de J. H. Turner e mostraremos que ela fundamenta a possibilidade de medida do CE da classe por leigos, que utilizamos em nossa pesquisa. 
Os pesquisadores, então, analisaram os eventos à luz de aspectos de teorias da interação social como as de Turner (2007), Collins (2004), Bakhtin (1988, apud Tobin et al; 2013), entre outras, e constataram que, a despeito da professora reportar à sua formação que estabelecia a importância do professor criar e manter o controle sobre os alunos, os eventos em que, apesar de muito barulho na classe, os alunos mostraram maior efervescência coletiva (Bakhtin, 1988; apud Tobin et al; 2013) e a professora se ligou a essa efervescência coletiva, a lição fluiu e os alunos transitavam com fluência dos risos, palmas, etc. para as discussões sobre os conteúdos de ciências; ao contrário de quando a professora promoveu situações de controle disciplinar, onde os alunos continuavam o que estavam fazendo e não davam atenção à abordagem dos conteúdos. Dessa forma, os autores mostraram que o aumento do CE foi associado às atividades nas quais a professora e os alunos colaboraram, demonstrando sintonia emocional e foco mútuo. (Tobin et al, 2013)

Em um estudo que avança um pouco além dos encontros presenciais face a face, Bellocchi; Mills; Ritchie (2016) realizaram uma análise microssociológica de encontros virtuais. Considerando as emoções expressas nas reações de professores de ciências em formação ao assistirem vídeos de suas aulas presenciais, focaram no surgimento, na manutenção e no rompimento dos laços sociais experimentados online pelos professores enquanto compartilhavam suas experiências emocionais de aprendizagem online através de blogs, ou diários de e-motion. Os professores em formação sentiram-se incluídos no grupo enquanto assistiam aos vídeos das atividades de sala de aula. Os diários de e-motion forneceram um recurso para as interações focadas em experiências emocionais compartilhadas, levando à formação de laços sociais e ao alívio de sentimentos de medo e ansiedade em se tornarem professores de ciências. Os pesquisadores identificaram, no trabalho online dos futuros professores com seus alunos, que ao contrário de estudos anteriores que apontavam que o ensino online pode ser isolador, os alunos podem criar laços sociais que facilitam a sintonia emocional, dependendo dos recursos que forem utilizados. Identificaram que ao assistirem a vídeos de demonstrações científicas os alunos apresentam emoções mesmo assistindo aos vídeos sozinhos. Assim, o recurso dos vídeos de demonstração científicas podem fomentar vínculos e interações de uma maneira similar como ocorrem durante as interações face a face. 
Poucos estudos se voltaram para detalhes das expressões dos professores durante o trabalho com os alunos. Tobin et al. (2016) exploraram essas emoções expressas por uma professora em seu primeiro ano de magistério para ajudá-la a reconhecer melhor suas emoções.

Tobin et al. (2016) investigaram as expressões das emoções da professora e suas mudanças fisiológicas com base na teoria polivagal $(\mathrm{PVT})^{8}$, ao mesmo tempo em que ela estava recebendo orientações para o trabalho em sala.

Os pesquisadores adotaram a metodologia de investigação orientada por eventos (Sewell Jr, 2005) por meio de análise da frequência cardíaca, da oxigenação do sangue e das expressões de emoções da professora, a partir da qual centraramse em cinco eventos para realizar análises multinível e multivariadas. A escolha de utilizar a frequência cardíaca e a oxigenação do sangue (por meio de oxímetros ${ }^{9}$ ) como heurísticos para busca de eventos salientes (Sewell, 2005) foi feita com base na teoria polivagal, a qual estabelece que alterações emocionais causam influências no nervo vago que realiza o controle parassimpático de determinados órgãos como coração, intestino, diafragma; por isso, alterações no batimento cardíaco e na oxigenação do sangue podem (embora não sejam as únicas causas) estar relacionados com resposta fisiológica causada por estímulo emocional, podendo causar alterações na fala, na oxigenação do sangue e nos batimentos cardíacos.

$\mathrm{Na}$ busca por eventos salientes (alterações bruscas no desenrolar do fluxo de acontecimentos que pode ser percebido, por exemplo, no batimento cardíaco, no padrão ou timbre de voz, na oxigenação do sangue - este último por meio de

\footnotetext{
${ }^{8}$ A Teoria Polivagal (PVT) trata da funcionalidade do décimo nervo craniano (nervo vago) que realiza o controle parassimpático do coração, pulmões e do trato digestivo. A teoria foi introduzida em 1994 pelo Dr. Stephen Porges, da Universidade de Illinois, em Chicago. De acordo com essa teoria, o sistema nervoso automático está interligado e é sensível a influências. Ainda de acordo com essa teoria, grande parte do comportamento social e das emoções têm relações fisiológicas importantes com esse nervo, uma vez que existe uma união neuroanatômica entre as ramificações do nervo vago e os de outros nervos cranianos, especialmente os responsáveis pela interação social através da expressão facial e da vocalização.
}

${ }^{9}$ Oxímetros são aparelhos médico hospitalares não invasivos utilizados para monitoramento de sinais vitais como batimento cardíaco e oxigenação do sangue. Os mais atuais são utilizados na ponta do dedo indicador. Seu funcionamento se baseia em medir a saturação da hemoglobina do sangue arterial $\left(\mathrm{SpO}_{2}\right)$ por meio de medida da luz vermelha e infravermelha (geralmente $660 \mathrm{~nm}$ e $940 \mathrm{~nm}$ ) que atravessa ou é refletida pelos tecidos, utilizando para isso, de um lado LEDs como fontes de luz e do outro, fotodetector que capta a luz remanescente. Por meio de cálculos fundamentados na Lei de BeerLambert, que estabelece a relação entre a concentração de um soluto em uma solução com a intensidade da luz transmitida através da solução, indica a concentração de oxigênio no sangue. (FERNANDES; OJEDA; LUCATELLI, 2001). Dessa forma, os oxímetros são indicativos das alterações fisiológicas que podem ser afetadas pelos estados emocionais, sendo por isso utilizados por Tobin et al. (2016) como heurísticos para identificar os estados emocionais da professora pesquisada. 
oxímetros) os pesquisadores se voltaram para esses eventos e, com uma metodologia hermenêutica-fenomenológica, buscaram compreender o que estava acontecendo nesses eventos.

Nesses eventos foram consideradas a narrativa, a análise prosódica e, por meio de uma metodologia hermenêutica-fenomenológica, buscaram aprender mais sobre as expressões de emoções quando a professora teve aumento da frequência cardíaca (antes e durante a aula), baixa oxigenação no sangue (antes e durante a aula) e alta oxigenação no sangue (enquanto ensinava). O objetivo era compreender as expressões e emoções vivenciadas pela professora.

A pesquisa constatou que as situações sociais relacionadas às emoções referidas pela professora desencadeiam o sistema de monitoramento ao reconhecer danos sociais, promovendo mudanças para o nervo vago que acabam desligando os órgãos e os músculos associados à comunicação - resultando em irregularidades na prosódia e nas expressões de emoções.

Ao conscientizarem a professora dos propósitos da pesquisa e dos resultados obtidos, como a influência que sua prosódia, seu estado de ânimo ou de raiva, proporcionaram-Ihe ferramentas para implementar mudanças em sua prática de ensino, especialmente na prosódia, influenciando no empenho dos alunos com o objetivo de melhorar o ritual de interação na sala de aula.

Nos eventos em que houve alta frequência cardíaca e baixa oxigenação do sangue, e às vezes prosódia confusa, incluindo a entonação, o ritmo da fala e pausas, o ambiente foi associado a padrões menos afetivos e, às vezes, confusos. Nos eventos de baixa oxigenação no sangue, havia evidências de fala rápida e respiração baixa e irregular. Em contrapartida, durante um evento em que houve $100 \%$ de oxigenação do sangue, a prosódia foi percebida como momento que produziu o engajamento e que a professora reportou emoções positivas, como satisfação ao ensinar.

Olitsky (2013) explorou as implicações dos estudos de Bellocchi et al. (2013) visando compreender melhor como promover um clima emocional positivo na sala de aula para os professores de nível primário. Baseando-se em teorias de solidariedade interacional, a autora explorou as implicações do CE (clima emocional) para aumentar a capacidade dos professores em formação de evitarem 'rituais de solicitação' e criarem comunidades centradas na ciência em suas salas de aula. 
Muitos estudos têm mostrado a relação entre as emoções, o clima emocional da aula e o desenvolvimento de ambientes de aprendizagem, considerando-os como partes de uma interação social em microescala, com vistas a produzir um ambiente que propicie um maior engajamento dos alunos. Muitos desses estudos se referem aos professores em formação ou em suas primeiras atuações em sala de aula.

Alguns estudos já mostraram que certas formas de abordagens em sala de aula podem produzir emoções negativas e baixos níveis de engajamento dos alunos, como em momentos de monólogos e tons de voz inadequados (Roth; Tobin, 2010; Rinchen; Ritchie; Bellocchi; 2016), podendo influenciar os rituais de interação em sala de aula e o engajamento dos alunos.

Uma questão ainda pouco explorada diz respeito às situações em que os professores podem estar quebrando a interação social e o que pode estar por trás de certos comportamentos que inviabilizem rituais de interação ou que, mesmo que estejam voltados para o processo de ensino e aprendizagem, possam se afastar dessa intenção primeira, interrompê-la ou desviá-la. Pensando-se em cada abordagem do professor como um encontro social em microescala, muito pode ser revelado sobre como suas atitudes, rituais, expressões e emoções podem influenciar no envolvimento dos estudantes.

As emoções, enquanto partes intrínsecas das interações sociais em microescala, podem revelar comportamentos sociais na interação face a face que os professores praticam ao trabalharem com seus alunos, seja conduzindo alguma atividade ou explicando os conhecimentos científicos.

Viennot (2006), argumentando que certos rituais nas práticas de ensino dos professores de Física podem fazer teorias físicas parecerem inconsistentes ou até mesmo absurdas, já havia investigado tais rituais dos professores no ensino secundário e superior e discutido formas de melhor destacar a consistência das ideias, uma vez que eles parecem não perceber tais inconsistências. A pesquisadora aponta que muitas vezes as explicações sobre conceitos ou fenômenos físicos são reproduzidas pelos professores como rituais de explicação, sem que estes se deem conta da incoerência ou inconsistência física, outras vezes alguns conceitos são transmitidos como claros, apesar de só fazerem sentido para a comunidade de físicos, pois envolvem uma simplificação de conceitos e procedimentos.

Neste artigo a autora aborda um exemplo de um problema apresentado aos professores, alunos do doutorado e constata a explicação que apresentam de forma 
muito ritualística (no sentido que reproduzem explicações aparentemente sem se questionarem sobre elas). Os professores foram questionados sobre a melhor forma de utilizar um 'cobertor de sobrevivência' contra a hipotermia, e explicam que tem uma parte reflexiva que faz o calor irradiado do nosso corpo refletir no material, utilizando um raciocínio linear em termos das definições físicas para calor e temperatura. Ao que a pesquisadora contrapõe que a explicação é mais complexa, sendo análoga a um 'circuito' de condutores e isolantes térmicos associados em série e em paralelo, no qual temos que verificar o fluxo resultante, pois o cobertor tem diversas camadas e a não consideração desse aspecto pode levar ao uso incorreto ou pouco eficiente da manta. A pesquisadora constatou que existe uma forte atração dos professores para explicarem em termos de um fluxo de uma entidade (calor) do corpo humano em direção ao ar externo, que é bloqueado pelo forte poder reflexivo do lado prateado do cobertor de sobrevivência, representando um argumento que não leva em conta o que ocorre entre $\mathrm{o}$ ar coberto e o ar externo e, portanto, representa uma forma muito simples de raciocínio causal linear; e a existência de vários compartimentos a serem considerados provou ser questionável para um aluno, o que é um indício de que uma abordagem de sistema não é imediatamente óbvia.

Uma questão que se apresenta no artigo é como professores que estudaram a Física durante alguns anos não se questionam sobre certas inconsistências ou mesmo incoerências. Por que eles incorporam essas explicações e passam a utilizá-las sem refletirem sobre elas? E também, por que, muitas vezes, mesmo conhecendo propostas didáticas e metodológicas de ensino inovadoras muitas vezes deixam de colocá-las em prática, ou então as subvertem?

Acreditamos que o processo de aquisição do conhecimento pelo professor e sua aplicação com os alunos não são apenas processos didáticos ou metodológicos, mas antes uma interação social em microescala que envolve outras questões; em particular o papel do professor na produção de emoções que ocorrem nas interações sociais do tipo encontro face a face. Por isso, entendemos que conhecer melhor situações em que professores em formação, durante as interações sociais face a face com alunos, possam estar subvertendo algum aspecto das prerrogativas didáticas, metodológicas ou mesmo conceituais, pode servir de alerta para a as influências dos aspectos emocionais e situacionais enquanto partes da interação social. 
Dessa forma, pode-se fomentar aspectos a serem trabalhados com os professores em sua formação para promover um ensino que faça sentido para os alunos e no qual não sejam meros espectadores ou reprodutores de explicações padronizadas, mas sim alunos questionadores, pensantes, reflexivos acerca dos fenômenos e dos princípios físicos.

É comum professores de Física afirmarem que poderiam dizer qualquer coisa que os alunos aceitariam. Assim, conhecer um pouco melhor sobre a interação social em microescala pode ajudar a criar subsídios para intervir na formação desses futuros professores e também dos que estão em exercício, posto que estes podem perpetuar certas práticas de interação social que não contribuam para a aprendizagem da Física.

Os professores, ao mesmo tempo em que começam a colocar em práticas metodologias de ensino ou didáticas de abordagens dos conhecimentos da Física se deparam com um encontro presencial face a face em que estão envolvidas não apenas estruturas sociais da escola e da função do professor, mas também o próprio encontro em si, as contingências deste e as emoções do professor. Conhecer melhor como essas questões interferem nos próprios encontros, e consequentemente no desenvolvimento da aula, pode ajudar a traçar estratégias para estabelecer rituais de interação de sucesso, no sentido de facilitar que ocorra a aprendizagem e que esta esteja de acordo com os conhecimentos científicos os quais são os objetivos do processo educacional para as aulas de Física.

Possivelmente, o professor tem um compromisso conceitual que se baseia nos conhecimentos científicos os quais pretende que os alunos compreendam ou com a metodologia de ensino que ele pretende aplicar. Entretanto, haverá outros compromissos (emocionais, sociais, etc.) que podem fazer esse professor, durante o encontro presencial, subverter aquele compromisso com o rigor científico ou com os preceitos metodológicos e didáticos para o ensino?

Conhecer um pouco mais sobre os aspectos envolvidos nessas situações de quebra de rituais, as emoções envolvidas em momentos em que ocorrem uma quebra dos rituais de interação, podem contribuir para a construção de rituais de interação bem-sucedidos dentro da sala de aula. Pois, como já apontou Collins: 
a parte emocional nos dá algo essencial para uma teoria realista - sua dinâmica. (COLLINS; 2004. p.103, grifo nosso, tradução nossa)

Por isso, conhecermos melhor as condições sobre as quais surgem certas emoções dos professores durante suas abordagens em aula pode fomentar uma explicação e uma perspectiva para subsidiar a formação desses professores com vistas a se tornarem inovadores, questionadores, coerentes e desenvolverem boas habilidades de mediar o processo de ensino e aprendizagem com seus alunos.

Voltarmos a atenção para o papel das emoções no processo educacional pode enriquecer as pesquisas e trazer elementos para o nosso entendimento enquanto pesquisadores e para fomentar os professores sobre o papel sempre presente das emoções, e assim complementar a formação dos professores.

Por vezes, nos deparamos com a suposição de que basta o professor ser instruído sobe os conhecimentos específicos e os conhecimentos pedagógicos para lecionar de forma competente. Mas, o ato de se tornar professor é um processo que se inicia antes da formação acadêmica, se estende por seu exercício diário e envolve diversos aspectos.

Entendemos que a formação do professor é complexa, repleta de idas e vindas, de dúvidas, de erros e acertos, de emoções que fazem parte desses encontros, e algumas podem marcar sua formação inicial.

A formação do professor não pode ser entendida como um processo apenas de aquisição de conhecimentos pedagógicos e específicos, em que ao final temos um professor de Física, pronto para desenvolver os conhecimentos científicos e aplicar as metodologias e didáticas aprendidas durante sua formação acadêmica.

Assim, além de já possuírem uma formação anterior, por meio da sua formação ambiental durante o período em que foram alunos (Gené e Gil, 1987; Hewson e Hewson, 1988; Calderhead, 1989; In.: CARVALHO \& GIL PÉREZ, 1992) os professores estão desenvolvendo suas habilidades da maestria a cada momento, em situações que ocorrem nos encontros presenciais face a face.

Acreditamos que conhecer melhor aspectos da atuação do professor em formação considerando os encontros face a face, identificando quais aspectos emocionais e situacionais que estão envolvidos nesses encontros, contribui para repensar a formação dos professores com vistas a torná-los mais conscientes, capazes de colocar em prática o pensar, o investigar, o gosto pelo aprender física. 
A partir disso, pode-se compreender melhor quais aspectos estão em ação quando os futuros professores estão em exercício, bem como mudar certas visões ou comportamentos nos encontros sociais que ocorrem na sala de aula. 


\section{TEORIZAÇÕES SOBRE AS EMOÇÕES}

O estudo sobre as emoções envolve diversas áreas do conhecimento, sobretudo no campo da psicologia humana; e quando falamos em emoções, pensamos também sobre sentimentos e afetividade, muitas vezes entendidas a priori como sinônimos. Mas aqui cabe algumas considerações acerca desses termos.

$\mathrm{Na}$ literatura encontra-se por vezes a utilização dos termos afeto, emoção e sentimentos, aparentemente, como sinônimos. Como já apontado por Leite e Tassoni (2002), os termos são de difícil conceituação mesmo no campo das pesquisas sobre a psicologia humana.

Engelmann (1978) (apud Leite e Tassoni, 2002) fez uma profunda revisão terminológica sobre as variações semânticas ao longo do tempo, das palavras relacionadas com emoções, sentimentos, estados de ânimo, e afeto, em diversos idiomas (francês, inglês, alemão, italiano e português), com intuito de conseguir uma maior precisão de significado para cada termo, visando corrigir o caráter vago dos termos e procurou abarcar também as teorias psicológicas. Concluiu que a maioria dos que pesquisaram a respeito desses fenômenos do comportamento humano reconhecem a necessidade de estabelecer distinções entre eles, embora não haja concordância a respeito de tais diferenciações.

Mas, a maioria das vezes o termo emoção aparece mais relacionado ao componente biológico do comportamento humano, às componentes físicas ou fisiológicas do corpo, enquanto afetividade aparece com uma significação mais ampla, ligada às vivências pessoais, a um 'estado de espírito' ou sentimentos que não são apenas momentâneos, tendo relações com questões psicológicas mais amplas, mesmo que caracterizados ou desencadeados por emoções mais momentâneas.

De acordo com Leite e Tassoni (2002), para Henri Wallon existe uma distinção entre emoções e afetividade.

[...] as emoções são manifestações de estados subjetivos, mas com componentes orgânicos. Contrações musculares ou viscerais, por exemplo, são sentidas e comunicadas através do choro, significando fome ou algum desconforto na posição em que se encontra o bebê. Ao defender o caráter biológico das emoções, [Wallon] destaca que estas originam-se na função tônica. Toda alteração emocional provoca flutuações de tônus muscular, tanto de vísceras como da musculatura superficial e, dependendo da natureza da emoção, provoca um tipo de alteração muscular. (...) A afetividade, por sua vez, tem uma concepção mais ampla, envolvendo uma gama maior de manifestações, englobando sentimentos (origem psicológica) e emoções (origem biológica). A afetividade corresponde a um período mais tardio na evolução da criança, 
quando surgem os elementos simbólicos. Segundo Wallon, é com o aparecimento destes que ocorre a transformação das emoções em sentimentos. A possibilidade de representação, que consequentemente implica na transferência para o plano mental, confere aos sentimentos uma certa durabilidade e moderação. (LEITE; TASSONI, 2002; pp. 117 e 118)

António Damásio (2012), analisando até que ponto os processos racionais e não racionais estão alinhados respectivamente com as estruturas corticais e subcorticais do cérebro humano, aborda as emoções e os sentimentos como constituintes centrais da regulação biológica que estabelecem uma ponte entre os processos racionais e os não racionais.

Assim, busca uma diferenciação entre emoções e sentimentos. As emoções, Damásio (2012) divide em dois tipos: as emoções primárias (ou inatas), comuns nas crianças, que se encontram inatamente instaladas nos humanos e também em outros animais, pois estamos programados para termos certas reações como medo de um urso ou de cobras, e as emoções secundárias, que se constituem por processos mentais mais complexos como quando reencontramos um amigo há muito ausente, ao saber da morte de um conhecido, ou outras situações que desencadeiam a ação do córtex pré-frontal e que promovem a liberação de substâncias que alteram nossas funções corporais musculares das mais variadas formas e até mesmo o sistema imunológico. Essas respostas pré-frontal provêm de representações que incorporam conhecimentos relativos às vivências pessoais, ou seja, representações adquiridas e não inatas.

Com relação aos sentimentos, Damásio (2012) os diferencia de emoções por considerar que

[...] apesar de alguns sentimentos estarem relacionados com as emoções, existem muitos que não estão: todas as emoções originam sentimentos, se se estiver desperto e atento, mas nem todos os sentimentos provêm de emoções. Chamo sentimentos de fundo aos que não têm origem nas emoções. (DAMÁSIO; 2012, p.138)

E identifica que os sentimentos estão relacionados a uma construção mental mais complexa:

Em outras palavras, um sentimento depende da justaposição de uma imagem do corpo propriamente dito com uma imagem de alguma outra coisa, tal como a imagem visual de um rosto ou a auditiva de uma melodia. O substrato de um sentimento completa-se com as alterações nos processos cognitivos que são induzidos simultaneamente por substâncias neuroquímicas (por exemplo, pelos neurotransmissores numa série de pontos neurais, em resultado da ativação dos núcleos neurotransmissores que faziam parte da resposta emocional inicial). (DAMÁSIO; 2012, pp. 140 e 141) 
Damásio (2012) ainda divide os sentimentos em três tipos: sentimentos de emoções universais básicas, sentimentos de emoções universais sutis e sentimentos de fundo.

Mas, apesar de diferenciar os termos emoção e sentimentos, e ainda subdividindo ambos os termos, acrescenta a seguinte ponderação em relação a essas diferenciações:

As definições de 'emoção' e 'sentimento' aqui apresentadas não são ortodoxas. Outros autores usam essas mesmas palavras indistintamente. O termo 'sentimento' pode nem mesmo ser usado, ou o termo 'emoção' ser dividido em componentes expressivos e experienciados. $O$ uso sistemático dos termos diferentes que proponho pode ajudar o avanço da futura investigação desses fenômenos. (DAMÁSIO; 2012, p. 141, nota de rodapé)

Damásio (2012), argumentando que pesquisas no campo da neurociência têm mostrado que os sentimentos parecem depender de um delicado sistema com múltiplos componentes que são indissociáveis da regulação biológica, e que a razão parece depender de sistemas cerebrais, alguns dos quais processam os sentimentos, acredita que pode existir um elo, em termos anatômicos e funcionais, entre razão e sentimentos e entre esses e o corpo; sendo esse um erro de Descartes: fazer uma separação abissal entre corpo e mente; expressa nos seus escritos e sintetizada na frase: Penso, logo existo.

O fato é que as emoções fazem parte da nossa natureza humana e também dos animais, e se manifestam ou são expressas de várias formas, desde as posturas corporais, as expressões faciais até as entonações da voz. E uma criança, desde tenra idade já consegue imitar ou reagir ao que comunicamos a ela através de expressões de emoção.

O naturalista britânico Charles Darwin, propositor da teoria da evolução das espécies, já havia apontado em $A$ expressão das emoções no homem e nos animais, publicada em 1872, sobre as diferenças entre as expressões faciais das emoções autênticas e das emoções simuladas. Darwin (2009) buscou mostrar que algumas de nossas expressões são resquícios herdados de antepassados primitivos comuns ao homem e a outros animais, sendo muitas delas inatas e não aprendidas, pois aparecem em várias culturas. Darwin relata diversas posturas e expressões observadas por ele em pessoas e animais.

Darwin (2009) chega a relatar a postura com os olhos revelando as emoções: 
[...] um homem que rejeita veementemente uma proposta quase com certeza fechará seus olhos ou desviará o rosto. Mas se aceitar a proposta, ele balançará a cabeça afirmativamente com os olhos bem abertos. Nessa última situação, o homem age como se pudesse claramente ver o caso, e na primeira situação, como se não pudesse ou não quisesse ver. Percebi que as pessoas, ao descreverem algo assustador que tenham visto, frequentemente fecham os olhos com força por um instante, ou mexem a cabeça, como para não ver ou afastar o acontecido. (...) uma pessoa, quando tenta lembrar de alguma coisa, muitas vezes levanta as sobrancelhas como para poder vêla. (DARWIN; 2009, p.40)

As tecnologias mais atuais, que não estavam disponíveis à época de Darwin e seus sucessores, permitem fazer filmagens que podem ser vistas e revistas, estudadas em detalhes minuciosos repetidas vezes, gravações e análises de sons e até mesmo imagens tomográficas do cérebro podem ser usadas para estudar as relações das expressões corporais com as emoções e até mesmo mapear áreas do cérebro.

Relações entre as posturas corporais, as expressões faciais e as emoções mais recentemente vêm recebendo atenção e sendo estudadas em maiores detalhes por vários pesquisadores (Paul Ekman, Richard Lazarus, Robert Zajonc, FreitasMagalhães) com o intuito de desvendarem as emoções e até revelar alguns pensamentos comuns a diversas expressões corporais e faciais, e que já foram até exploradas na série para TV Lie to Me, realizada sob a consultoria e o acompanhamento de Paul Ekman.

Esses estudos mais atuais ampliaram bastante aquelas anotações de Darwin sobre suas observações de diversas situações em que nosso corpo dá sinais sobre o que estamos pensando ou sentindo e seus progressos foram conseguidos a partir de uma visão das emoções como parte de um processo de interação social, presente já em nosso cérebro em processos originados geneticamente.

A maioria desses estudos identifica que, a despeito da complexidade das emoções e dos sentimentos humanos, existem algumas emoções que são básicas, como medo, raiva, tristeza, felicidade; e cujas expressões são muito parecidas em diferentes culturas. E que sendo elas tão básicas, estariam relacionadas a alguma estrutura básica de nosso cérebro, determinada geneticamente.

Um contraponto à ideia de que somos dotados de emoções básicas, inatas e, portanto, comuns a todos os humanos aparece no trabalho de Tiffany Watt Smith, da Queen Mary University of London, apresentado em seu livro The Book of Human Emotions - An Encyclopedia of Feeling from Anger to Wanderlust. Para ela, o fato de 
diferentes culturas possuírem gestos e até palavras diferentes para expressar emoções demonstra que as emoções são dependentes da cultura ${ }^{10}$.

Como historiadora das emoções, ela pesquisou as origens históricas das emoções humanas. Para isso, foi buscar nas diversas culturas de vários países, a origem de vários termos relacionados a emoções. Smith (2015) faz uma breve crítica às pesquisas atuais em neurociência que se valem de tecnologias modernas de varredura do cérebro e procuram conhecer melhor como as emoções funcionam no cérebro humano por meio de imagens coloridas no computador.

Com seus emaranhados brilhantes de magenta e esmeralda, estudos do cérebro podem ser sedutores. Eles podem até parecer a última palavra sobre como e por que sentimos da maneira como fazemos. Mas pensar em nossas emoções puramente como fogos de artifício bioquímicos no cérebro é, nas palavras do escritor Siri Hustvedt, "preferir dizer que Vermeer's Girl Pouring Milk é uma tela com tinta ou que a própria Alice é uma palavra em uma página. Isto são fatos, mas eles não explicam minha experiência subjetiva de nenhum deles ou o que as duas garotas significam para mim. Mais do que isso, penso, abordar as emoções considerando como primeiro e mais importante os aspectos biológicos distorcem o que realmente é uma emoção". (SMITH; 2015, p.2-3, tradução nossa)

Smith (2015) até situa o que ela chama de origem histórica das emoções, ou como ela se refere, "a invenção das emoções":

Ninguém realmente sentiu emoções antes de 1830. Em vez disso, sentiram outras coisas - "paixões", "acidentes da alma", "sentimentos morais" - e explicavam-nas muito diferente da forma como entendemos as emoções hoje. (SMITH; 2015, p.3, tradução nossa)

A pesquisadora chama atenção para o fato que, apesar de no século I a.C. já existir a ideia confucionista de que somos dotados de emoções básicas e o próprio René Descartes, no século XVII, ter sugerido a existência de sete emoções básicas humanas, as correntes atuais que estudam as emoções sofreram as influências do trabalho de Darwin sobre as emoções e posteriormente do trabalho do médico, com formação em neurologia, Sigmund Freud; enquanto os estudos sobre a vertente

10 A palavra cultura tem recebido diversas compreensões dentro das ciências sociais. Até aqui a utilizamos várias vezes quando referida na revisão bibliográfica. Não pretendemos realizar uma discussão aprofundada sobre seu significado, mas a partir daqui adotaremos a palavra na acepção utilizada por Sewell Jr (2005), na qual, cultura humana é o sistema de símbolos e significados que fornecem uma fonte suplementar de informação que não apenas uma conveniência para os seres humanos, mas uma necessidade fisiológica de nossa dotação biológica, que evoluiu em conjunto com a evolução do cérebro e não apenas quando da enorme evolução do córtex cerebral (como defendido por alguns antropólogos); e por isso, as culturas não são, necessariamente, logicamente consistentes, altamente integradas, consensuais, resistentes a mudanças e claramente delimitadas. 
antropológica dos anos 1960 e 1970 é que começaram a dar um enfoque cultural para as emoções.

Assim, aponta uma discordância - sem embasar em termos sociológicos, psicológicos ou biológicos, ao fato de podermos utilizar meia dúzia de palavras para expressar as emoções humanas.

Porque uma coisa que eu aprendi, como uma exploradora neste novo e elegante mundo emocional, é que o que precisamos não é de menos palavras para nossos sentimentos. Nós precisamos de mais palavras. (SMITH; 2015, p.11, tradução nossa)

A partir de suas colocações, Smith (2015) inicia a descrição por ordem alfabética e quase enciclopédica de 152 palavras únicas utilizadas em diferentes países para expressar emoções. Aqui citaremos apenas um exemplo, pertencente à língua portuguesa.

Como bem sabemos, a palavra saudade, sem uma equivalente em outras línguas, só existe na língua portuguesa. Ela é uma das 'emoções' apresentadas por Smith (2015), que reproduzimos a seguir.

Acredita-se que os portugueses aprenderam a falar da emoção saudade no século XIX, durante a Era dos Descobrimentos. Os navios partiam do porto de Lisboa a caminho da África e da América do Sul. Aqueles deixados para trás viveram seus dias examinando o horizonte, desejando o retorno de seus entes queridos. As mulheres trovadoras cantavam sua soidade (a ortografia mais antiga) em suas cantigas d'amigo ("músicas sobre um namorado"), suas letras melancólicas que expressam uma dor pelo amado distantes e a felicidade do passado. Hoje, as pessoas falam de sentir saudade não só por pessoas distantes, mas também por lugares distantes e até objetos perdidos.

SAUDADE: um anseio melancólico por alguém, ou algo que está longe ou perdido. Está sempre lá, pulsando abaixo da superfície com sua ESPERANÇA tingida com PESAR. Há um anseio vago, mas está interligado com resignação e o prazer de lembrar de alegrias passadas.

[...] No início do século XIX, a saudade encontrou sua forma moderna na música do fado. Significado de "fatalidade" ou "destino", o fado nasceu nas calçadas do distrito de Alfama em Lisboa, lar de marinheiros e prostitutas. Influenciadas pela música afrobrasileira trazida a Portugal pela família real e sua comitiva ao retornar do exílio no Brasil na década de 1820, as guitarras soluçantes do fado e as vozes ensejantes evocam a experiência da pobreza, da perda e da infidelidade dos amantes. O fado pretende também livrar o cantor da melancolia agridoce da saudade. Então, cantar fado é matar saudades. Literalmente: 'matar a saudade'.

Veja também: NOSTALGIA.

(SMITH; 2015, pp. 6-7, tradução nossa)

Neste exemplo, como em outros que não exploraremos aqui, fica claro que Smith (2015) está apresentando palavras que possuem uma construção histórica e cultural relacionada às emoções vivenciadas por um povo localizado no tempo e no 
espaço e, neste caso, a um período histórico marcante do povo português. Poetas como Fernando Pessoa, em Ode Marítima (heterônimo Álvaro de Campos) ou Mar Portuguez já colocaram em versos os sentimentos relacionados à essa época na história de Portugal:

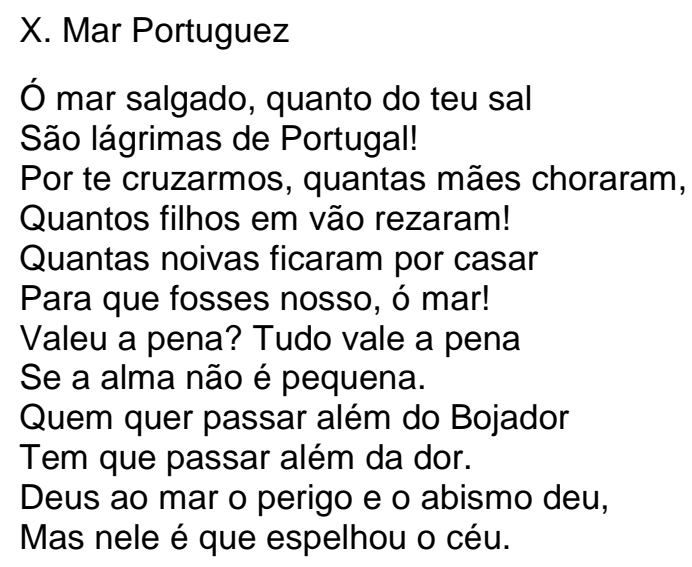

Pensemos em como as pessoas que estavam vivendo naquela época poderiam sentir-se ao ter uma pessoa de seu convívio partir, sem nenhuma forma de ter notícias (carta, e-mail, WhatsApp, ou redes sociais), e os meses seguintes esperando pela volta sem saber se retornariam. Possivelmente havia um misto de emoções (medo, tristeza, angústia, etc.) e provavelmente essas emoções dependiam também da relação que tinham com a pessoa que partiu. Assim, a palavra saudade acabou abarcando um sentimento marcado por um misto de emoções, dando à palavra saudade uma construção num determinado momento histórico, mas que também sofreu as alterações que o significado da palavra foi ganhando com o passar do tempo, uma vez que a língua falada é viva, não estanque.

A possibilidade da construção linguística de termos para expressar emoções e sentimentos ou conjuntos de emoções é aceita pelos teóricos das emoções básicas. Ou seja, que a cultura influencia na construção de termos que expressem emoções é perfeitamente plausível. Mas, isso não significa que não existam emoções básicas, anteriores a essa cultura, e que estejam no âmago desse sentimento originado em um certo momento, em uma determinada cultura.

Assim, aceitar que existam emoções básicas não tira a pluralidade nem a riqueza das emoções humanas, assim como dizer que toda matéria é feita de prótons, nêutrons e elétrons não tira a diversidade nem a riqueza da matéria que constitui o Universo. 
Matsumoto (2005), em um estudo sobre as diferenças culturais nos comportamentos e nas formas de expressar ideias e sentimentos, aponta que as formas como as pessoas podem demostrar emoções variam de uma cultura para outra, mas algumas emoções básicas possuem características universais.

As culturas também diferem consideravelmente no uso de comportamentos não-
verbais. Embora as expressões faciais de raiva, desprezo, desgosto, medo, felicidade,
tristeza e surpresa tenham uma base universal (Matsumoto, 2001), as culturas diferem
nas regras que governam o modo como essas expressões são usadas.
(MATSUMOTO; 2005, p.15-16)

Assim, entendemos que as emoções também são construídas culturalmente, sobretudo as palavras que utilizamos para expressar as emoções são constructos culturais. Mas isso não implica necessariamente que não existam emoções básicas na nossa estrutura mental. De forma que estudos como os de Smith (2015) não invalidam a ideia de emoções básicas comuns a todos os humanos.

$E$, ademais, os estudos sobre as emoções básicas não pretendem tirar a beleza das emoções humanas nem as representações delas, tantas vezes brilhantemente colocadas pelos poetas.

Assim como os conhecimentos que a ciência construiu para entender o corpo humano e seu funcionamento permitiram o avanço da medicina apesar de não significar que a ciência reproduza o complexo funcionamento de cada órgão no corpo humano. Da mesma forma, conhecer mais sobre as emoções pode nos ajudar a lidar melhor com elas, principalmente com aquelas que possuem um valor muito negativo. E conhecer mais sobre as emoções pode nos ajudar a entender melhor sobre quem realmente somos ou porque fazemos as coisas que fazemos.

Alguns estudos já mostraram fazer bastante sentido a existência de emoções básicas e chamam atenção para nossa capacidade inata para identificar algumas expressões de emoções e que são comuns a culturas diferentes, como quando olhamos para as emoções que parecem já estar presentes em crianças pequenas, ainda com pouca vivência cultural.

Quando entramos em contato uma primeira vez com uma cultura diferente da nossa, e da qual não conhecemos nada da língua falada nessa cultura, conseguimos identificar sinais como os de tristeza, alegria e raiva naquelas pessoas.

Wallon (1995) ao explorar as expressões das emoções nas crianças pequenas, já chamava atenção para a importância das emoções para a interação social, como quando a criança chora ao saber que está sendo observada pela mãe ou alguém 
próximo, mas se ela percebe que está sozinha interrompe seu choro prontamente; e também para o papel contagiante das emoções na formação dos grupos sociais.

É preciso crer que esse caráter contagioso e coletivo da emoção teve, não apenas sobre a sua própria evolução, mas na história do homem, uma importância decisiva, para que tenha sido sistematicamente cultivado, com a ajuda de práticas primitivas. Nas cerimônias, jogos e danças que acompanham tantos atos da vida pública ou individual, é fácil reconhecer simulacros próprios para suscitar em todos os participantes, sob formas e através de meios rigorosamente determinados, uma excitação e arroubos que correspondem às diversas variedades de emoção. [...] Assim, cada indivíduo se vê unido aos demais pelo gênero de manifestações que o revelam de imediato a si mesmo. Ele pertence ao grupo por suas modificações mais íntimas e pessoais, em lugar de se justapor simplesmente a outros indivíduos. (WALLON; 1995, p.99)

Wallon (1995) também aponta o papel das emoções na formação dos grupos sociais e seus rituais e a importância da emoção para o surgimento do conhecimento pois

sem atividade coletiva não há conhecimento, nem linguagem, nem simbolismo possível. Se, pois, a emoção ritualizada desempenha sem dúvida um papel no advento da atividade simbólica, se ela parece ter antecedido as manifestações mais decisivas da vida e da alma coletiva, é preciso reconhecer nela um intermediário necessário entre o automatismo e o conhecimento. (WALLON; 1995, p.102)

\section{E acrescenta:}

Não se trata aqui de afirmar a anterioridade do grupo sobre a emoção e a linguagem, ou o inverso. $O$ homem é simultaneamente um animal que fala e que vive em sociedade. A aptidão para a linguagem está inscrita em seu organismo, e um dos traços essenciais da espécie humana é a aptidão para a linguagem. Mas a existência da linguagem é inconcebível sem a existência social e sem a existência de sociedades duráveis. Ao contrário, a existência de sociedades sem linguagem não é inconcebível. Mas a existência da linguagem e suas modalidades responde necessariamente a tipos determinados de sociedade. Quanto à expressão emocional, ela é uma etapa que precede a linguagem no sentido triplo de que se inscreve em um estágio inferior, portanto mais primitivo, do cérebro, que não é uma aptidão particular à espécie humana; e enfim, que parece corresponder a um tipo gregário de ação e sociedade, isto é, a um tipo relativamente inferior e primitivo. (WALLON; 1995, p.102, nota de rodapé)

\section{Dessa forma, Wallon (1995) coloca as expressões das emoções como traços}

evolutivos comuns aos humanos, mas que vão sendo acrescidos pelo desenvolvimento da criança e desempenhando seu caráter social.

Assim, a expressão das emoções pode seguir a espécie em sua evolução e superpor aos seus centros subcorticais os da mímica, que têm sede no córtex, como os da linguagem. Em relação aos planos sucessivos da vida mental, a emoção pôde refinarse, a ponto de oferecer toda uma gama que vai das manifestações mais orgânicas às nuances mais delicadas da sensibilidade intelectual. As etapas dessa ascensão são reconhecíveis na criança. Seu riso e seu choro, no início, têm ponto de partida abdominal, antes de aparecer no rosto e iluminá-lo ou sombreá-lo silenciosamente. A 
região ativa de sua fisionomia é a boca, enquanto no adulto ela se transfere para os olhos e para a testa. (WALLON; 1995, p.101)

As relações entre as expressões corporais, e sobretudo as faciais, com as emoções já vêm sendo apontadas desde o trabalho de Darwin. Mas, só mais recentemente esses estudos foram aprofundados por diversas pesquisas, com destaque para o trabalho de Paul Ekman.

Ekman (2007) descreve sua experiência de quarenta anos de pesquisas interculturais em países de todas as regiões do planeta, na qual identifica as características básicas das expressões faciais que revelam algumas emoções básicas comuns em diferentes culturas.

Apesar de no início de suas pesquisas acreditar que as expressões emocionais eram socialmente aprendidas e culturalmente variáveis, a leitura do artigo de Darwin e seu contato com Silvan Tomkins, que afirmava acreditar que as expressões faciais eram inatas e universais, mas que não tinha as evidências para reivindicar tal afirmação, Ekman (2007) passou a estudar as expressões corporais e faciais das emoções em busca de traços comuns, com o intuito de mostrar que aquelas expressões pudessem mesmo ser determinadas pela cultura.

Seu primeiro estudo, realizado em cinco países diferentes (Chile, Argentina, Brasil, Japão e Estados Unidos), que solicitava aos participantes julgarem quais eram as emoções mostradas em cada expressão facial, no entanto, chegou à conclusão que a maioria coincide em todas as culturas, sugerindo que as expressões de algumas emoções poderiam ser realmente universais.

Na continuidade de seus estudos, catalogou cerca de dez mil movimentos dos músculos do rosto para identificar os que estão relacionados a cada emoção. Esse estudo levou ao FACS (Facial Action Coding System), um sistema de reconhecimento facial já utilizado em diversos sistemas computacionais de reconhecimento facial e por institutos de investigações americanos como CIA (Central Intelligence Agency) e FBI (Federal Bureau of Investigation).

Ekman (2007) chama atenção para o fato de que suas pesquisas e os estudos atuais sobre o cérebro ajudaram a entender sobre as emoções, mas muitas coisas ainda precisam ser respondidas.

Uma das novas áreas de pesquisa mais ativas é sobre os mecanismos cerebrais da emoção. [...] mas ainda não sabemos o suficiente sobre o cérebro para responder a muitas das questões [...] Nós sabemos muito sobre o comportamento emocional, o suficiente para fornecer respostas a algumas das questões mais importantes sobre 0 
papel das emoções em nossa vida cotidiana.[...] Embora minhas pesquisas e as descobertas de outros forneçam a base para o que descrevo [...] alcancei o que foi comprovado cientificamente para incluir também o que acredito ser verdade, mas ainda não está comprovado. (EKMAN; 2007, p.16, tradução nossa)

Ekman (2007) identificou nas expressões faciais sete emoções humanas que considera universais: tristeza, raiva, surpresa, medo, desgosto, desprezo e felicidade.

Buscando construir uma teoria sociológica para compreender as origens do comportamento social humano e sua relação com as emoções, Turner (2003) mostrou duas dezenas de trabalhos já realizados, desde o trabalho de Darwin em 1872, que tiveram como objetivo identificar essas emoções humanas primárias, até os trabalhos atuais de Paul Ekman.

Para justificar a existência das emoções humanas básicas como sendo herdadas de nossos ancestrais, Turner (2003) argumenta que nós humanos somos símios evoluídos e que os outros símios nossos primos ancestrais estão em declínio há milhões de anos, restando apenas quatro gêneros ou espécies: os chimpanzés (Pan), os gorilas (Gorilla), os orangotangos (Pongo) e o gibões/siamangas (Hylobates/Symphalangus).

De acordo com Turner (2003), a essência dos símios faz parte do nosso âmago, portanto

tudo aquilo ao qual se atribui um caráter único e singular no que se refere aos humanos, foi acumulado e empilhado por cima do nosso patrimônio simiesco. Não podemos, por conseguinte, desenvolver teorias e programas de investigação acerca dos humanos sem tomar em consideração o legado biológico da nossa ancestralidade simiesca, uma vez que continua a influenciar as ações e interações humanas. (TURNER; 2003; p.16)

E aponta a necessidade de considerar esses aspectos na análise do que se tornou o ser humano atual no mundo sociocultural moderno aparentemente desconectado da biologia humana.

As capacidades humanas de pensamento e razão, de ter emoções, e de comunicação verbal, são possibilitadas devido a estruturas anatômicas que facilitaram a adaptação dos nossos distantes antepassados primatas. Já não poderemos perspectivar este patrimônio evolucionário como se fosse uma "caixa preta" ou como um dado adquirido; em vez disso, temos que mergulhar na nossa história evolucionária e ver como continua a influenciar, a cada momento, todos os encontros face-a-face entre humanos. (TURNER; 2003; p.17)

Trazendo uma grande gama de pesquisas arqueológicas e biológicas, Turner (2003) traça o caminho dos nossos primatas mostrando, por exemplo, a necessidade da visão para os que habitavam as copas das árvores, pulando com precisão para 
saltar e correr de uns ramos para outros, ou fazendo com que nossos ancestrais símios que migraram para as savanas africanas tivessem declínio do bulbo olfativo esta redução ocorreu muito provavelmente uma vez que, no nível neurológico, um sentido olfativo altamente sensível poderia interferir na predominância visual, especialmente porque o bulbo olfativo penetra nos centros emocionais subcorticais do cérebro. (TURNER, 2003)

Turner (2003) aponta que a estrutura social da maior parte dos macacos do Velho Mundo é matriarcal, com os machos submetidos à hierarquia das fêmeas, permanecendo junto ao grupo natal apenas até a puberdade, enquanto as fêmeas permaneciam juntas, em uma estrutura hierárquica mantida por até quatro gerações, conferindo uma estrutura mais estável e mais coesa do que a encontrada entre os símios.

Nossos ancestrais símios, ao contrário, tinham pouca tendência social, sendo bastante individualistas. Mas, apesar da pouca tendência social dos símios mesmo após a passagem das árvores para a savana, os primeiros hominídeos enfrentaram todo tipo de intempéries e a seleção natural fez tomar um caminho diferente e elaborar capacidades emocionais, e a partir desta linha emergiu a linhagem Homo. (TURNER, 2003)

Turner (2003), seguindo seu raciocínio, argumenta que a partir daí esses hominídeos teriam desenvolvido evolutivamente uma reorganização e elaboração das estruturas límbicas subcorticais e uma reestruturação dos sistemas neocorticais e do tronco cerebral

com vistas a produzir um animal que pudesse utilizar e ler uma ampla variedade de deixas e pistas emocionais com o objetivo de atingir uma coesão e ligação social realçada e intensificada. (TURNER; 2003, p.49)

Assim, para Turner (2003), essas características dos símios permanecem na estrutura biológica do homem moderno por nossa ascendência simiesca; sendo a capacidade de interpretar emoções algo inato, pelo menos em alguns aspectos básicos da forma de sentir e expressar emoções.

O que Turner (2003) faz ao considerar a capacidade humana de ler e interpretar emoções como algo inato e adquirido evolutivamente, é semelhante, do ponto de vista da fundamentação e das bases argumentativas, ao que Noam Chomsky fez com a questão das línguas faladas. 
Chomsky (2005), intrigado com o fato de sermos a única espécie que possui a capacidade de desenvolver a língua falada e com o fato da criança pequena poder aprender dezenas de palavras por dia como se fosse do nada, propôs que a capacidade da língua é uma característica humana inata já programada geneticamente em nossas estruturas cerebrais; como uma espécie de língua básica, a partir da qual podemos construir ou aprender as línguas nativas.

Dessa forma, Chomsky (2005) revolucionou o estudo das línguas faladas ao propor a existência de uma gramática gerativa, algo como uma gramática básica universal, comum a todas as línguas, e presente em nosso cérebro desde 0 nascimento. ${ }^{11}$ Apesar das inúmeras críticas que recebeu às suas pesquisas, sobretudo de linguistas e filósofos, e de seu próprio reconhecimento de que ainda não chegou a uma teoria final ou a uma comprovação dos processos mentais envolvidos na formação primitiva da língua, são amplamente reconhecidas as contribuições que as suas pesquisas e as de seus colaboradores têm feito para os avanços no estudo da linguística.

Tanto Chomsky (2005) quanto Turner (2003) buscam se fundamentar em estudos originados nas ciências naturais, no sentido de tentar encontrar nas bases da biologia, da química e da física o entendimento de processos mentais que possibilitam o funcionamento das línguas e das emoções, respectivamente.

Mas esse enfoque toca um problema filosófico antigo, abordado por René Descartes, Hume e outros filósofos, que diz respeito ao problema corpo-mente ou, como colocado por alguns filósofos, corpo-alma. Aqui não estamos nos propondo a entrar nessa discussão filosófica, mas poderíamos dizer, grosso modo, que o problema tem basicamente duas correntes: uma materialista que defende que a mente é um produto da atividade cerebral e a outra não materialista que acredita que a mente é algo além do cérebro fisicamente constituído. ${ }^{12}$

\footnotetext{
11 De acordo com GARDNER (1985), Chomsky, com seu trabalho Three Models of Language, de 1956, faz parte da revolução cognitiva iniciada nos anos 1955-1960 e que se caracteriza pela busca por entender o funcionamento da mente e envolve diversas áreas (naquela primeira década: psicologia, filosofia, linguística, antropologia, neurociência e inteligência artificial).

12 O problema corpo-mente, que a rigor remonta ao tempo de Platão, tem sua discussão moderna a partir das colocações de René Descartes (e com retomada a partir dos avanços das neurociências). Para uma visão rápida do problema sugerimos, por exemplo: Fodor (1981), que mostra que esse problema ainda é inerente à Psicologia e seus estudos sobre a mente e o comportamento humano. Outro artigo que ajuda compreender o problema é: As críticas de Henri Bergson e de Maurice MerleauPonty aos enfoques materialistas do problema corpo-mente (VERISSIMO e FURLAN, 2009). O Professor Oswaldo Pessoa Jr, da Universidade de São Paulo, também aborda o problema mente-corpo
} 
Mas, nossa formação na área de ciências da natureza e nossas concepções acerca do mundo natural, que não exclui o humano como inerente à natureza, nos levam a acreditar que a mente não pode existir independente do corpo e que tanto $o$ corpo pode influenciar nos processos mentais quanto a mente pode agir sobre o corpo. E dessa forma, as ideias de Chomsky (2005) ou as de Turner (2003) nos parecem bem razoáveis e capazes de fundamentar pesquisas nas áreas das linguagens ou das emoções.

Entendemos que isso ainda carece de comprovações irrefutáveis, de descrições mais específica sobre os processos envolvidos que ligam o corpo e a mente e como eles ocorrem, mas isso não impede que avanços nas pesquisas possam ocorrer mesmo sem uma explicação final e pormenorizada dos aspectos que estão na base dessa relação.

Nosso trabalho considera a possibilidade de as emoções estarem regulando as relações humanas nos encontros sociais e se fundamenta no trabalho de Turner (2007) o qual explorou como a organização social e a cultura inerente a toda organização social provocam a excitação de valências emocionais ao longo de um contínuo de positivo a negativo, além de mostrar a partir de emoções básicas (felicidade, medo, raiva, tristeza e surpresa) e pelas misturas dessas emoções, ser possível dar origem as emoções secundárias e terciárias.

ao tratar das alegações de que a Física Quântica seria ferramenta para a explicação da consciência. (PESSOA JR, 1994). O fato é que essa é uma questão sem resposta definitiva, apenas argumentos filosóficos podem ser colocados sobre os mais variados enfoques. Talvez, os estudos das neurociências, das tecnologias de computação e inteligência artificial poderão (ou não) no futuro dar uma resposta definitiva a essa questão. 
Tabela 2: emoções de primeira ordem com as combinações das emoções básicas que as constituem. (TURNER; 2007, p.8)

\begin{tabular}{|c|c|c|}
\hline Primary emotions & & First-order elaborations \\
\hline \multicolumn{3}{|l|}{ satisfaction-happiness } \\
\hline satisfaction-happiness + aversion-fear & $\rightarrow$ & $\begin{array}{l}\text { wonder, hopeful, relief, gratitude, } \\
\text { pride, reverence }\end{array}$ \\
\hline satisfaction-happiness + assertion-anger & $\rightarrow$ & $\begin{array}{l}\text { vengeance, appeased, calmed, } \\
\text { soothed, relish, triumphant, bemused }\end{array}$ \\
\hline $\begin{array}{l}\text { satisfaction-happiness }+ \text { disappointment- } \\
\text { sadness } \\
\text { aversion-fear }\end{array}$ & $\rightarrow$ & nostalgia, yearning, hope \\
\hline aversion-fear + satisfaction-happiness & $\rightarrow$ & awe, reverence, veneration \\
\hline aversion-fear + assertion-anger & $\rightarrow$ & $\begin{array}{l}\text { revulsed, repulsed, antagonism, } \\
\text { dislike, envy }\end{array}$ \\
\hline $\begin{array}{l}\text { aversion-fear }+ \text { disappointment-sadness } \\
\text { assertion-anger }\end{array}$ & $\rightarrow$ & dread, wariness \\
\hline assertion-anger + satisfaction-happiness & $\rightarrow$ & $\begin{array}{l}\text { condescension, mollified, rudeness, } \\
\text { placated, righteousness }\end{array}$ \\
\hline assertion-anger + aversion-fear & $\rightarrow$ & abhorrence, jealousy, suspiciousness \\
\hline $\begin{array}{l}\text { assertion-anger }+ \text { disappointment-sadness } \\
\text { disappointment-sadness }\end{array}$ & $\rightarrow$ & bitterness, depression, betrayed \\
\hline $\begin{array}{l}\text { disappointment-sadness }+ \text { satisfaction- } \\
\text { happiness }\end{array}$ & $\rightarrow$ & $\begin{array}{l}\text { acceptance, moroseness, solace, } \\
\text { melancholy }\end{array}$ \\
\hline disappointment-sadness + aversion-fear & $\rightarrow$ & $\begin{array}{l}\text { regret, forlornness, remorseful, } \\
\text { misery }\end{array}$ \\
\hline disappointment-sadness + assertion-anger & $\rightarrow$ & $\begin{array}{l}\text { aggrieved, discontent, dissatisfied, } \\
\text { unfulfilled, boredom, grief, envy, } \\
\text { sullenness }\end{array}$ \\
\hline
\end{tabular}

Por exemplo, uma quantidade maior de satisfação-felicidade, combinada com uma certa dose de aversão-medo, gera novas emoções como maravilha, esperança, alívio, gratidão e orgulho (veja o topo da Tabela na página anterior). Para todas as outras combinações de emoções primárias aparecem tipos análogos de novas emoções. (TURNER, 2007)

Turner (2007) defende que as emoções básicas (ou primárias) possibilitaram a construção das emoções de primeira ordem por meio de habilidades que estavam presentes nos primeiros hominídeos. A seleção natural criou a neuroanatomia humana (ou talvez do antecessor hominídeo) para gerar as emoções de primeira ordem, que são uma mistura das emoções primárias. De forma análoga, ocorreu com as emoções de segunda e terceira ordens.

Dessa forma, as emoções mais elaboradas, originadas de uma combinação de várias emoções, acabam se constituindo com o processo cultural de cada agrupamento humano. Assim, é por isso que hoje vemos diferenças sobre a expressão das emoções em culturas diferentes e temos a impressão de que as emoções e as formar de expressá-las variam de uma cultura para outra. O que de fato 
acontece, mas apenas como constructo cultural, não significando com isso que existam emoções apenas como processo cultural. Antes, existem as emoções que foram originadas em nosso processo evolutivo e que são comuns a todos os humanos.

Por isso, os estudos que rementem as emoções ao contexto cultural não invalidam de forma alguma a ideia das emoções básicas.

A ideia da existência das emoções básicas, corroboradas pelos estudos de Paul Ekman sobre as relações entre expressões faciais, emoções básicas e a existência de padrões universais, apesar das variações culturais que possam surgir nas emoções secundárias e terciárias, nos fundamentam a adotar a ideia da capacidade humana em detectar se não uma emoção específica, pelo menos um contínuo que vai das emoções negativas até as positivas, como sugerido por Ekman (1992).

Nossa pesquisa se vincula aos estudos que investigam as emoções no processo educacional, mas parte do pressuposto de que as emoções existem, surgem, se modificam, desaparecem e voltam, porque somos seres sociais; se fôssemos sozinhos, não expressaríamos emoções (pelo menos as mais complexas, quiçá as mais básicas).

Portanto, entendemos as emoções para além de um processo interno psíquico, o qual se constitui em uma habilidade humana intrínseca da sociabilidade e que faz parte do processo de interação face a face.

Em virtude disso, interessa-nos investigar as emoções enquanto partes de uma interação social que ocorre em cada encontro presencial entre professor e alunos ou entre alunos, para assim, compreendermos melhor o processo que torna um estudante professor e talvez, conhecer aspectos que possam ser barreiras para que eles realizem o processo de ensino e aprendizagem com seus alunos.

As emoções não são apenas importantes em si, elas são a base das interações humanas que permitem as estruturas e que geram a própria cognição. Como aponta Turner (2007):

[...] precisamos ver as emoções em seus termos mais robustos, como uma força na ação humana que evoluiu e que opera continuamente para aumentar ou diminuir a viabilidade da cultura e das estruturas sociais. (TURNER; 2007, p.43, tradução nossa)

A linguagem falada e o advento da escrita pode ter-nos feito considerar a cognição como relacionada à aquisição dessas linguagens. E de fato está relacionada 
com a linguagem, mas, como aponta Turner (2007), existe uma linguagem anterior a essa e que ainda está presente em nossas interações sociais.

A linguagem das emoções e a nossa capacidade em reconhece-las pelas posturas e movimentos do corpo pode chegar a 76\% das emoções em ambiente com luz indireta e $86 \%$ em ambientes bem iluminados (ATKINSON et al., 2004)

E, por outro lado, a interação falada não é nem a primeira nem mesmo a mais importantes para entendermos as interações face a face. Pois, como aponta Goffman:

A tendência humana de usar sinais e símbolos significa que a evidência de valor social
e de avaliações mútuas será transmitida por coisas muito pequenas, e essas coisas
serão testemunhadas, bem como o fato de que elas foram testemunhadas. Um olhar
de relance, uma mudança momentânea no tom de voz, uma atitude tomada ou não,
podem tornar o significado de uma conversa crítico. (GOFFMAN; 1982, p.33, tradução
nossa)

Assim, procuramos utilizar uma forma de identificar alterações nas emoções durante o encontro face a face que constitui os momentos em que os estagiários abordam conceitos de física e que não dependa dos sujeitos se reportarem a posteriori sobre o que sentiram, a qual passamos a explicar. 


\section{TEORIAS MICROSSOCIOLÓGICAS: AS INTERAÇÕES FACE A FACE}

Como mencionado anteriormente, o estudo do clima da aula por muito tempo foi tratado com menoridade devido à falta de um referencial teórico que 0 fundamentasse. Durante muito tempo as teorias psicológicas, principalmente aquelas que investigaram e traçaram vários aspectos relacionados ao processo da aprendizagem e da cognição, estiveram no centro das pesquisas educacionais nas salas de aula de ciências.

Uma das teorias que mais embasou as pesquisas educacionais foi a dos estudos piagetianos sobre o processo de aprendizagem, um estudo teórico sobre trocas intelectuais e desenvolvimento cognitivo por estágios.

Para Piaget, as trocas intelectuais possuem três regras específicas: o sistema comum de signos e de definições; a conservação das proposições válidas, obrigando a reconhecê-las como tal e a reciprocidade de pensamentos entre os interlocutores. (LA TAILLE, 1992)

Piaget considera que as crianças pequenas ainda não conseguem realizar as três regras. Segundo o autor, uma criança de 4 anos não possui uma escala de referência comum. Dessa forma, cada criança pode utilizar definições diferentes ou cada uma pode não conservar necessariamente a definição inicial que ela mesma utilizou durante a conversa. A explicação de Piaget para isso é que a criança pequena é fundamentalmente egocêntrica.

Desta maneira, parece que Piaget considera o processo de aprender como uma estrutura cognitiva interna que, seguindo as três regras, vai evoluindo de estágios, até que os sujeitos se tornem adultos os quais conseguem se colocar no lugar do outro e realizar trocas intelectuais profícuas.

Mas, o próprio Piaget já havia apontado que essas trocas não são frutos apenas de processos internos, cognitivos, mas também das relações sociais:

Se tomarmos a noção do social nos diferentes sentidos do termo, isto é, englobando tanto as tendências hereditárias que nos levam à vida em comum e à imitação, como as relações 'exteriores' (no sentido de Durkheim) dos indivíduos entre eles, não se pode negar que, desde o nascimento, o desenvolvimento intelectual é, simultaneamente, obra da sociedade e do indivíduo. (PIAGET, J. Études Sociologiques. Genebra-Paris, 1977, p.242, apud: LA TAILLE, 1992, pp. 11-12)

Para Piaget, existem dois tipos de relações sociais nas trocas intelectuais: de coação e de cooperação. No primeiro há elementos de autoridade ou prestígio, marcado por uma assimetria entre os sujeitos, caracterizado por imposição, repetição, 
crença, etc.; já no segundo ocorrem trocas de pontos de vistas, com controles dos argumentos e das provas, e uma capacidade de se colocar no lugar do outro. Piaget coloca a cooperação no mais alto nível de socialização das trocas intelectuais. (LA TAILLE, 1992)

Assim, podemos resumir que os processos de trocas intelectuais e a socialização para Piaget estão relacionados e que evoluem à medida que ocorre o crescimento biológico dos sujeitos e estes vão se afastando do egocentrismo.

Como aponta La Taille (1992), Piaget tratou com pouca relevância a questão da cultura (ideologias, religiões, classes sociais, sistemas econômicos, escolarização), só considerando como importante a oposição coação versus cooperação. E ao considerar o aspecto social do desenvolvimento cognitivo dependente da perda do egocentrismo e o consequente desenvolvimento para o uso de trocas de cooperação, considerou o social e suas influências sobre os indivíduos na perspectiva da ética e, dessa forma, demonstrou justamente seu pressuposto; ou seja, de que o valor ético da igualdade, da liberdade e da democracia que os indivíduos irão alcançar são os requisitos necessários para o desenvolvimento intelectual. (LA TAILLE, 1992)

Essa visão piagetiana de que evoluímos naturalmente do egocentrismo para uma capacidade de cooperação e não de coação, como se fossemos apenas seres cognitivos racionais na vida adulta, ou destituídos de traços egocêntricos - como se essa fosse uma característica exclusiva das crianças pequenas, parece-nos um pouco exagerada, pois o ser humano é mais complexo; e acreditamos que a cognição não se trata apenas de uma faculdade racional, mas está repleta de pensamentos emocionais e até irracionais. Certamente, a cultura, a educação, com os parâmetros de convivência coletiva criam os códigos que ajudam a construir indivíduos conscientes, com valores colaborativos; mas, sem a cultura e a educação, tendemos a ser meros sujeitos egoístas e pouco colaborativos. ${ }^{13}$

\footnotetext{
${ }_{13}$ Veja-se os diversos exemplos de situações em nosso dia a dia em que gentileza e mesmo atitudes racionais estão ausentes nas pessoas de sociedades com poucos valores de coletividade. Por exemplo, no trânsito da cidade de São Paulo ou de tantas outras cidades brasileiras os motoristas não cedem a vez ou tentam forçar a passagem numa via com confluência e trânsito muito intenso, fazendo parar totalmente a outra via com obrigatoriedade de dar a preferência e deixando de aplicar o mais racional que seria ir intercalando os carros sem que nenhuma das vias chegasse a parar. Porém, quando se faz esse procedimento os próximos carros tendem a fazer o mesmo, deixando evidente que 0 comportamento colaborativo ou a gentileza são constructos das relações sociais.
} 
Os trabalhos de Piaget, enquanto epistemologista genético, focaram nos processos cognitivos, deixando os aspectos emocionais de lado. Mas, outro estudioso do desenvolvimento psicológico infantil, Henri Wallon, buscou compreender o desenvolvimento por meio de processos interativos da criança, focando no aspecto afetivo.

De visão marxista, Wallon foi politicamente ativo, chegando a filiar-se ao Partido Comunista Francês. Sua teoria para o desenvolvimento psicológico tem forte relação com sua visão marxista, considerando a aprendizagem como um processo dialético. Defendia que a cognição se desenvolve por estágios; porém de forma dialética entre os campos funcionais, num processo constante de tese, antítese e síntese, que tem seu início com as primeiras reações de emoções vivenciadas pela criança recémnascida, adotando uma abordagem fundamentalmente social do desenvolvimento humano.

Para Wallon, que dedicou grande parte de seu trabalho ao estudo da afetividade, a emoção é o primeiro e mais forte vínculo entre os indivíduos, sendo fundamental observar o gesto, a mímica, o olhar, a expressão facial, pois são constitutivos da atividade emocional. (DANTAS, 1992).

Por isso, segundo Wallon (1959), desde o nascimento a criança possui uma simbiose afetiva, que até os três meses é quase uma simbiose alimentar. Mas, a partir do terceiro mês a criança já consegue se dirigir a quem a rodeia, e particularmente à sua mãe, não só chorando pelo cuidado que ela necessita, mas expressando sorrisos e sinais de satisfação que são um elo puramente afetivo entre ela e aqueles que interagem com ela. E a partir do sexto mês as relações humanas já são quase tão importantes quanto a sua comida.

Wallon entendia, em consonância com os fundamentos darwinistas (prole reduzida em comparação com outros mamíferos e longo período de dependência entre a prole e os genitores que caracterizam a importância da proximidade do outro para o desenvolvimento humano), que as origens humanas são de um ser emocional. (DANTAS, 1992)

Essa ideia está em consonância com as teorias microssociológicas que consideram as interações face-a-face como a base da formação social humana e repletas de aspectos emocionais, como a desenvolvida no trabalho de Turner (2007).

Entendemos que as trocas intelectuais são interações entre os sujeitos e que essas trocas possuem suas próprias características de encontros sociais em 
microescala. Assim, parece-nos que o papel da interação social no processo educacional é crucial e precisa ser melhor estudado. Isto posto, precisamos considerar os estudos das Ciências Sociais como fundamentais para a compreensão do processo educacional.

Aqui cabe apontar que, mesmo relativamente jovem, a Sociologia possui algumas tradições de abordagens, com características próprias. Utilizando a classificação de Collins (2009), podemos dividi-la basicamente em quatro tradições: do conflito, racional-utilitarista, durkheiminiana e microinteracionista. Esta última é uma tradição que se desenvolveu bastante com os sociólogos americanos e teve seu embrião na Sociologia alemã, sobretudo com a publicação de Gemeinschaft und Gesellschaft (Comunidade e Sociedade) de Ferdinand Tönnies em 1880, que define dois tipos de vontades humanas: Wesenwille (que se caracteriza pelas vontades naturais) e a Kürwille (que é uma vontade racional e calculada). (COLLINS, 2009).

A microssociologia busca estudar os encontros face a face como processos de interação social em si. Uma das críticas que os sociólogos dessa corrente costumam fazer sobre os estudos que normalmente se faz do comportamento humano durante contatos sociais é o fato de comumente aceitarmos como verdade que as pessoas são seres únicos, donos de um caráter próprio, que não cedem à pressão social. Segundo Collins, (2004), essa visão tem sua raiz, em grande parte, na cultura judaicocristã. Para Collins (2004), o indivíduo é único apenas à medida que os seus caminhos, por meio de cadeias de interações, seu rol de situações vivenciadas ao longo do tempo, diferem dos percursos de outras pessoas.

A microssociologia busca compreender os fundamentos mais básicos da interação social para ajudar a desenvolver uma teoria suficientemente poderosa no nível micro e assim revelar alguns segredos das mudanças sociológicas em grandes escalas. (COLLINS, 1981)

Para ajudar na compreensão e descrição adequadas das situações, Collins (1981) afirma que devemos ver os indivíduos como fluxos transitórios cobrados por situações, pois as formas como as pessoas se comportam nos encontros sociais revela mais sobre essas situações do que algo que seja próprio delas ou das suas personalidades.

Turner (2007) propôs uma teoria sociológica com base nas emoções, de acordo com a qual, a realidade social se desenvolve em três níveis: micro, meso e macro. 
O nível micro corresponde aos encontros sociais face-a-face como duas pessoas conversando ou um pequeno grupo realizando alguma atividade conjunta. $O$ meso corresponde ao surgimento das unidades corporativas ou categóricas, ou seja, as organizações, as comunidades e grupos, como quando os primeiros hominídeos começaram a se organizar para caçar, formaram grupo familiares, etc. Enquanto o macro da realidade social é o nível dos domínios institucionais e dos sistemas de estratificações, os sistemas sociais e intersociais: economia, política, parentesco, religião, direito, ciência, medicina, educação e similares. (TURNER, 2007)

No nível micro estão as forças de excitação emocional, as necessidades transacionais, os símbolos, o status, os papéis, a demografia e a ecologia; e essas forças conduzem a formação e a operação dos encontros. Eles também podem moldar a formação e operação de unidades corporativas e categóricas de nível meso. Por um lado, essas forças do micronível moldam o fluxo do comportamento interpessoal em encontros; e, ao fazê-lo, se reproduzem ou, potencialmente, mudam a divisão do trabalho de unidades corporativas ou as distinções e avaliações de unidades categóricas. À medida que as pessoas interagem face a face, elas despertam emoções ao construir símbolos culturais, criar posições e desenvolver papéis a desempenhar nessas posições, organizar ações no espaço usando vários adereços (ecologia) e criando novas distinções categóricas (demografia); e à medida que essas forças de micronível são executadas, os encontros criam, sustentam ou modificam unidades corporativas e categóricas. (TURNER; 2007, p.71, tradução nossa)

Assim, o nível micro é o foco das pesquisas microssociológicas. E dentre os vários enfoques microinteracionistas, dois que marcaram as bases dessa abordagem são as ideias propostas por Erving Goffman com o conceito de Ritual de Interação e mais recentemente, Randall Collins, com uma sistematização geral para descrição dos elementos que caracterizam os Rituais de Interação e a ideia de Cadeia de Rituais de Interação.

A microssociologia busca entender os encontros presenciais como encontros sociais em si, que caracterizam não apenas a natureza social do comportamento humano, mas também as situações em si. Em cada encontro, as situações carregam as emoções dos sujeitos presentes fisicamente e estas são partes fundamentais da interação social. Daí a importância de a considerarmos como uma sociologia das situações, não das pessoas.

Collins (2004) aponta que quanto mais nos esforçarmos para pensar tudo por meio da sociologia das situações, mais vamos entender o motivo pelo qual agimos de determinada maneira. Dessa forma, a microssociologia das situações vai descrever os encontros presenciais enquanto encontros sociais que se constituem em si mesmos, sem focar o indivíduo, ou outros fatores que não sejam a situação analisada. 
[...] nós conseguimos mais começando com a situação e desenvolvendo sobre o indivíduo, do que começando pelos indivíduos; e obtemos muito mais do que pelo caminho usual de passar do indivíduo para a ação ou a cognição que pertence a ele ou a ela e ignorando a situação por completo. Uma teoria do ritual de interação (RI) e de cadeias de rituais de interação é sobretudo uma teoria das situações. É uma teoria de encontros momentâneos entre os corpos humanos carregados de emoções e consciência porque passaram por cadeias de encontros anteriores. (COLLINS; 2004, p.6, tradução nossa)

4.1. Rituais de Interação e Cadeias de Rituais: os encontros face a face.

Os estudos microssociológicos ou a sociologia das situações investiga os encontros face a face para compreender como as pessoas se comportam e agem diante das outras. Um sociólogo importante que desenvolveu estudos sobre tais encontros foi Erving Goffman. Para ele, o cerne da vida social é o mundo físico e a presença real dos corpos humanos nesse mundo. Assim, os elementos que determinam como as pessoas falam ou respondem não são totalmente explicados pelas formalidades da linguagem, mas pelo domínio das relações sociais, ou seja, pelos modos como as pessoas se comportam diante das outras. (GOFFMAN, 1982)

$\mathrm{Na}$ coletânea de trabalhos intitulada Interaction Ritual: essays on face-to-face behavior, Goffman (1982) traça um estudo sobre a classe de eventos que ocorrem durante a copresença e por causa da copresença, investigando os materiais comportamentais como olhadelas, gestos, posicionamentos corporais e expressões verbais que as pessoas utilizam nas situações, intencionalmente ou não, aos quais considera serem

sinais externos de orientação e envolvimento - estados mentais e corporais que geralmente não são examinados em relação à sua organização social. (GOFFMAN, 1982; p.1, tradução nossa)

Para estudar as interações dos encontros sociais em microescala, Goffman (1982) vai mais além, defendendo uma sociologia das situações e afirmando que:

[...] o estudo adequado da interação não é o indivíduo e sua psicologia, mas antes as relações sintáticas entre os atos de diferentes pessoas mutuamente presentes. (GOFFMAN, 1982, p.2; tradução nossa, grifo nosso)

Goffman considera que os sujeitos constituem sua interação social em cada encontro, apresentando nesses encontros características intrínsecas da sociabilidade 
humana e que é também neles que se estabelece a estrutura social pelos próprios sujeitos presentes no encontro.

Uma estrutura normativamente estabilizada está em questão, um "encontro social"; mas esta é uma entidade mutável, necessariamente evanescente, criada por chegadas e assassinada por partidas. (GOFFMAN, 1982; p.2, tradução nossa) ${ }^{14}$

Assim, a microssociologia de Goffman considera que por debaixo das diferenças culturais, as pessoas são iguais em todos os lugares.

Se as pessoas possuem uma natureza humana universal não é nelas que devemos buscar uma explicação dessa natureza. É preciso observar que as sociedades em todos os lugares, se são sociedades, precisam mobilizar seus membros como participantes autorreguladores nos encontros sociais. (GOFFMAN, 1982; p.44, tradução nossa)

Goffman (2012) pressupõe que, quando os indivíduos se interessam por qualquer situação usual, eles se confrontam com a pergunta: "O que é que está acontecendo aqui?", seja ela formulada explicitamente, ou tacitamente. E é isso que ele procura estudar na situação.

Minha perspectiva é situacional, o que significa aqui uma preocupação com o que um indivíduo pode estar ciente em um dado momento, e isso frequentemente envolve alguns outros indivíduos determinados e não está necessariamente restrito à arena mutuamente controlada de um encontro face a face.. (GOFFMAN; 2012, p.30, tradução nossa)

Mas, chama atenção para o fato de que essa análise poder ser feita com uma visão mais aberta ou mais fechada sobre a situação.

Devo dizer desde já que a pergunta "O que é que está acontecendo aqui?" é bastante suspeita. Qualquer evento pode ser descrito em termos de um enfoque que inclui um espectro amplo ou um espectro estreito e - como um problema relacionado, mas não idêntico - em termos de um foco em primeiro plano ou afastado. E ninguém tem uma teoria sobre qual a abertura e em qual nível ele deveria ser empregados. Então, eu devo ter o direito de escolher arbitrariamente minha abertura e meu nível, sem justificativa especial. (GOFFMAN; 2012, p.31, tradução nossa)

Para descrever os encontros face a face, Goffman utiliza o termo ritual pois considera que está lidando com atos em que o ator, através do comportamento simbólico desses atos, mostra o quanto ele tem o direito a ser considerado por aqueles atos e o quanto sente que os outros também são dignos de consideração pelos atos deles.

\footnotetext{
14 Dessa forma, Goffman rompe com uma visão de estrutura social estanque e imutável como muito defenderam os estruturalistas.
} 
O Ritual de Interação (RI) é considerado, dentro da microssociologia, a unidade básica das relações sociais. Portanto, investigar esses rituais nos ajuda a entender esses encontros.

Goffman (1982) considera o ritual como um mecanismo de emoção e de atenção focadas que produzem uma realidade momentânea compartilhada entre os participantes do encontro social; e destaca a importância do papel que as emoções desempenham nos rituais de interação.

Está claro que as emoções desempenham um papel nesses ciclos de respostas, como quando expressamos angústia pelo que alguém fez para [...] outra pessoa, ou raiva com relação ao que foi feito para nós [...]. Quero enfatizar que essas emoções funcionam como jogadas e se encaixam tão precisamente na lógica do jogo ritual que seria difícil compreendê-las sem ele. (GOFFMAN, 1982; p.23, tradução nossa)

\subsection{O conceito de fachada e seus tipos básicos de salvamento}

Para o estudo dos Rituais de Interação (RI), Goffman (1982) sugere olhar para os eventos nos encontros face a face como uma análise por si só, analiticamente distinta de outras áreas vizinhas como as relações sociais, pequenos grupos sociais, sistemas de comunicação e as interações estratégicas, visando identificar padrões e sequências naturais de comportamento que ocorrem sempre que pessoas entram na presença imediata de outros.

De acordo com Goffman (1982), durante os encontros presenciais as pessoas tendem a desempenhar o que podemos chamar de linha ou padrão de atos verbais e não verbais com os quais expressam suas opiniões. E não importa se elas queriam ou não assumir uma linha, pois sempre farão isso na prática. Em um RI então, tratase de verificar em que situação as linhas pelas quais um indivíduo pode se identificar, ou então constatar que uma linha se desmorona.

Goffman (1982) concorda que aspectos psicológicos estão necessariamente envolvidos em um RI, mas considera que esses aspectos estão despojados e comprimidos para se acomodarem ao estudo sociológico de encontros sociais como conversações, provas de atletismos, jogo de basquete, banquetes, julgamentos, aulas, ou conversas de rua.

Dessa forma, alguns conceitos são utilizados para compreender as ações ou comportamentos das pessoas nos encontros face a face. 
Imaginemos que um participante de um encontro acredite que determinada pessoa assumiu uma linha mais ou menos voluntariamente, de forma que sempre precisará considerar a impressão que os outros formaram dessa pessoa. Se os outros participantes aceitarem essa linha e a pessoa continuar nela, poderá tomá-la como algo válido para si e isso caracterizará a fachada dela.

O termo fachada pode ser definido como o valor social positivo que uma pessoa efetivamente reivindica para si mesma por meio da linha que os outros presumem que ela assumiu durante um dado contato. A fachada é uma imagem do eu delineada em termos de atributos sociais aprovados. (GOFFMAN, 1982; p.5, tradução nossa, grifo nosso).

Por isso, não basta que a pessoa queira ter uma fachada, ela precisa ser aceita pelos participantes do encontro face a face. A fachada é, pois, a linha que a pessoa assumiu para si e que foi aceita pelos demais participantes do encontro.

Quando o encontro sustenta a imagem da pessoa que ela dá como certa há muito tempo, provavelmente ela terá poucos sentimentos sobre a situação. Por outro lado, se a situação estabelecer uma nova fachada melhor do que a pessoa poderia esperar, provavelmente se sentirá bem. Todavia, se suas expectativas costumeiras não se concretizarem, tenderá a sentir-se mal ou sentir-se ofendida.

\begin{abstract}
Podemos dizer que uma pessoa tem, está com ou mantém a fachada quando a linha realmente assumida por ela apresenta uma imagem dela que é internamente consistente, que está apoiada por juízos e evidências comunicadas por outros participantes, e que é confirmada por evidências comunicadas por ações impessoais durante a situação. Nesses momentos, a fachada da pessoa claramente é algo que não está alojado dentro ou sobre seu corpo, mas algo difusamente localizado no fluxo de eventos do encontro, e que se manifesta apenas quando esses eventos são lidos e interpretados para obtermos as avaliações expressas neles. (GOFFMAN, 1982; pp. 67, tradução nossa)
\end{abstract}

Uma pessoa está sem fachada quando ela não tem uma linha do tipo que esperamos que indivíduos nessas situações tenham e está com a fachada errada quando a linha que está sendo assumida para ela durante um contato com outros não pode ser mantida, pois alguma informação sobre seu valor social que surgiu não pode ser integrada com a linha que está sendo mantida para ela.

Quando uma pessoa sente que está com uma fachada ou mesmo quando os outros a sentirem com a fachada errada, mas conseguirem esconder isso dela, a pessoa apresentará sentimentos de confiança e convicção.

Se a pessoa sentir que está com a fachada errada ou sem fachada, provavelmente se sentirá envergonhada e inferior. Esses sentimentos são decorrentes 
do impacto negativo que tal descoberta poderá ocasionar a sua reputação enquanto participante do encontro.

Durante os encontros existe uma regra de respeito a sua própria fachada e uma regra de consideração às fachadas dos outros e o efeito combinado dessas duas regras é que durante os encontros a pessoa tende a se conduzir de forma a manter tanto a sua fachada quanto as dos demais participantes. De acordo com Goffman (1982), essa aceitação mútua é uma característica estrutural básica da interação, principalmente das interações face a face. Ainda, a manutenção da fachada é uma condição da interação e não o seu objetivo.

As pessoas possuem uma capacidade de perceber formas de preservação da fachada que alguém esteja utilizando e assim se comportam com tato, diplomacia ou habilidade social, mantendo os devidos cuidados no trato social.

Os participantes do grupo podem agir também para salvar a fachada de alguém, mas ao fazê-lo as pessoas precisam escolher o método que não levará à perda de suas próprias fachadas; por outro lado, quando uma pessoa tenta salvar sua própria fachada, ela precisará ponderar sua ação para não causar a perda da fachada dos outros.

Portanto, para se manter na interação, a pessoa precisará ter um repertório de práticas de manutenção ou de salvamento da fachada para cada uma dessas ameaças à perda dela. Essas práticas de salvamento da fachada são rituais de interação (que apresentaremos a seguir) e que estão presentes nas interações humanas face a face, independentemente da cultura ou de outros fatores, pois, de acordo com Goffman (1982), por baixo das diferenças culturais, as pessoas são iguais em todos os lugares.

Assim, Goffman (1982) aponta alguns rituais básicos de salvamento da fachada: o aprumo, o processo de evitação, o processo corretivo e a cooperação.

\subsubsection{Aprumo}

Inicialmente, Goffman (1982) identifica que existe em muitas sociedades uma distinção entre três níveis de responsabilidade de uma pessoa por ter criado ameaças à fachada de alguém. Primeiro, a pessoa pode ter agido inocentemente, de forma não intencional ou involuntária, e os outros perceberem que ela poderia ter evitado a 
situação que pôs a fachada em risco se tivesse se dado conta de sua ofensa. Esses eventos são normalmente chamados de gafe, 'pisada de bola'. Segundo, a pessoa pode ter agido com malícia ou despeito, com clara intenção de causar um insulto. Terceiro, quando a ofensa surge de forma incidental, como um efeito colateral de uma ação que o ofensor realiza apesar de suas consequências ofensivas.

Goffman (1982) utiliza o termo aprumo para se referir à capacidade de suprimir e esconder qualquer tendência que a pessoa vivencie de ficar constrangida por estar com a fachada em risco durante o encontro.

Por meio do aprumo a pessoa controla o seu constrangimento e também o constrangimento que os outros poderiam sofrer por causa do seu constrangimento. Mas, às vezes, uma pessoa pode manifestar aprumo quando os demais participantes do encontro consideram que ela deveria oferecer uma desculpa constrangida.

Goffman (1982) considera o aprumo como uma forma básica de preservação da fachada. Mas, além dele, existem outros rituais de salvamento.

\subsubsection{Processo de evitação.}

O processo de evitação é uma forma mais garantida para uma pessoa se proteger de ameaças à sua fachada, evitando contatos nos quais seriam prováveis que essas ameaças acontecessem. Goffman aponta que em todas as sociedades se observa o processo de evitação na tendência de conduzir certas situações delicadas por meio de intermediários. Em muitas sociedades, as pessoas reconhecem o valor de voluntariamente realizar uma retirada graciosa antes que uma perda da fachada previsível aconteça.

Como medida preventiva, a pessoa se mantém longe de tópicos e de atividades que levariam a se expressar de formas que seriam inconsistentes com a linha que ela está mantendo. (Goffman, 1982)

Nos momentos apropriados, ela mudará o assunto da conversa ou a direção da atividade. Frequentemente, ela inicialmente exibirá uma atitude de timidez e compostura, suprimindo qualquer manifestação de sentimentos até que ela descubra que tipo de linha os outros estarão dispostos a apoiar para ela. (GOFFMAN, 1982; p.16)

Manobras protetoras também são muito utilizadas, como quando a pessoa demonstra respeito e polidez, cuidando para estender às outras pessoas o tratamento cerimonial que elas possam merecer. Ela emprega discrição e cortesia; por exemplo, ela não menciona fatos que possam contradizer os outros ou comprometer a fachada 
deles. A pessoa pode, por exemplo, dizer por antecipação que precisará ir embora, para que a fachada dela e as dos demais participantes estejam preparadas para isso, e fiquem protegidas.

Determinadas situações suscitam o processo de evitação como forma de manter a fachada. Mas, quando uma pessoa não consegue impedir um incidente, ela pode tentar manter a ficção de que não tenha ocorrido nenhuma ameaça à fachada.

\subsubsection{Processo Corretivo}

Quando durante um encontro os participantes percebem que um evento é incompatível com os juízos os quais estão sendo mantidos ou quando ele é difícil de ser ignorado, os participantes provavelmente darão a ele a característica de um incidente, considerarão que este é uma ameaça a qual merece atenção e tomarão providências para tentar corrigir os seus efeitos. Acontecerá, então, de um ou mais dos participantes estarem em desgraça ritual e o grupo tentará restabelecer um estado do ritual satisfatório para eles. Isso acontece porque, como aponta Goffman (1982),

Nossa fachada [...] é uma coisa sagrada, e a ordem expressiva necessária para mantêla é, portanto, uma ordem ritual. (GOFFMAN, 1982; p.19, tradução nossa)

\subsubsection{Cooperação}

Nos encontros face a face, é preciso realizar a preservação da fachada. E, de acordo com Goffman (1982), não importa se o salvamento é iniciado pela pessoa cuja fachada está ameaçada ou por outra pessoa, ou mesmo por uma mera testemunha.

Uma vez que cada participante de um encontro está preocupado, mesmo que por razões diferentes, em salvar sua própria fachada e também a fachada dos outros, surgirá naturalmente uma cooperação tácita para salvar a fachada, de forma que os participantes obtenham juntos seus objetivos em comum, mesmo que por motivos diferentes.

A diplomacia é um exemplo de cooperação. E muitas vezes para funcionar conta com o acordo tácito para agir por meio da linguagem das dicas - a linguagem das indiretas, ambiguidades, pausas bem colocadas, piadas cuidadosas. (GOFFMAN, 1982) 


\subsection{Outros elementos presentes nos rituais de interação}

Além dos rituais de salvamento da fachada, Goffman (1982) chama atenção para outros aspectos que fazem parte dos ritos realizados para representações da coletividade social que são às vezes realizados para o próprio indivíduo, recebendo um tipo de sacralidade que é exibida e confirmada por atos simbólicos, que apoiam dois conceitos básicos: deferência e porte. E também aponta a importância do constrangimento na sustentação das relações sociais.

\subsubsection{Deferência e porte}

A deferência é o componente que funciona como um meio simbólico que é utilizado para comunicar regularmente apreciação para um receptor a respeito deste receptor ou de algo sobre ele que seja considerado um símbolo, extensão ou agente. $E$ às vezes, tanto o receptor quanto o ator podem não ser indivíduos.

Uma pessoa pode desejar, ganhar ou merecer deferência, mas em geral não é permitido a ela o dar para si mesma. Por outro lado, a pessoa é forçada a procurar deferência nos outros. Goffman (1982), aponta que se o indivíduo pudesse dar a si mesmo a deferência que quisesse, a sociedade se desintegraria em solitários isolados 'venerando seu próprio altar'.

Uma pessoa pode fazer uma reivindicação teórica sobre sua deferência, mas se ela for precipitada é provável que a partir de então sua relação com os atores seja modificada. Muitos atos automáticos de deferência contém um significado vestigial e têm relação com uma atividade em que ninguém mais está engajado, implicando em uma apreciação que há muito tempo não é mais esperada, como quando muitos tributos antiquados não podem ser negligenciados impunemente. (GOFFMAN, 1982)

Os atos de deferência contêm, além de um sentimento de estima, uma espécie de promessa do ator em tratar o receptor de forma particular na atividade que seguirá.

Os principais rituais utilizados para garantir a deferência são o ritual de evitação e o ritual de apresentação (saudações, convites, elogios e pequenos serviços). Há uma oposição entre os dois rituais, pois há coisas que devem ser ditas ou feitas para um receptor e outras que não devem. Como por exemplo, quando uma pessoa com estatuto errado pergunta sobre a saúde de um familiar ou quando um sofrimento recente tornou a pergunta dolorosa para ser colocada. 
Goffman (1982) aponta que existe no intercurso social uma dialética constante entre rituais de apresentação e de evitação.

Além disso, os elementos do comportamento que ajudam a identificar sua fachada se revelam também em coisas que poderiam parecer menores como a postura ou a forma como a pessoa está vestida.

Os gestos que às vezes chamamos de vazios podem de fato ser as coisas mais cheias que existem. (GOFFMAN, 1982; p.91, tradução nossa)

Os elementos do comportamento cerimonial a que Goffman chama de porte é o que os indivíduos tipicamente comunicam por meio de postura, vestuário, aspecto, que servem para expressar aos outros, na presença imediata, que eles têm certas qualidades desejáveis ou indesejáveis.

\subsubsection{Constrangimento}

O constrangimento ocorre quando a fachada está em risco. Ele pode ser leve ou extremo e tem a ver com a figura que o indivíduo representa diante dos outros considerados presentes naquele momento e costuma se caracterizar por sinais objetivos de perturbação emocional: enrubescimento, balbucios, gaguejos, voz estranhamente aguda ou grave, fala trêmula ou entrecortada, suor, palidez, piscadelas, tremor nas mãos, movimentos hesitantes ou vacilantes, distração e disparates, rebaixamento dos olhos, mãos atrás das costas, dedos batucando a roupa ou torcidos entre si, curvar da cabeça. Mas podem haver também sintomas internos como: constrição do diafragma, percepção de gestos forçados e não naturais, sensação de tontura, boca seca, tensão nos músculos.

O embaraço, ou constrangimento, pode ocorrer por dois motivos: porque a pessoa pode estar engajada numa tarefa que não tenha nenhum valor particular para ela ou por causa da figura que o indivíduo representa diante dos outros considerados presentes naquele momento. Mas, o que Goffman (1982) vai centrar seu estudo é o no segundo caso, que tem relação clara com a presença real ou imaginária de outras pessoas.

Como formas de tentar ocultar o constrangimento, a pessoa pode apresentar um sorriso fixo, um riso vazio nervoso, as mãos ocupadas, o olhar para o chão que 
esconde a expressão dos olhos, levar os dedos ao nariz, coçar a cabeça, girar o chapéu. (GOFFMAN, 1982)

O constrangimento não é um impulso irracional destruindo o comportamento social, mas sim parte desse próprio comportamento ordenado. Pois, quando o indivíduo demonstra constrangimento ele não pode assumir nenhuma fachada, mas abre a possibilidade de no futuro poder assumir uma delas. Como aponta Goffman (1982), "ele sacrifica sua identidade por um momento, e às vezes o encontro, mas os princípios são preservados”.

Assim, Goffman (1982) considera que durante as interações os indivíduos apresentam certos atributos e comunicam certas informações que, em conjunto, se encaixam num eu que possui uma unificação coerente e que é apropriado para a situação.

De acordo com Martins (2008), para Goffman existe uma significativa carga emocional que perpassa o processo interacional, ao surgirem situações que criam sentimentos de desconforto, ansiedade, medo, vergonha e humilhação para os atores envolvidos na interação. E ainda, que Goffman privilegiou o sentimento de embaraço, que expressa uma sensação de desconforto experimentado em certos momentos nas interações face a face.

\footnotetext{
A possibilidade latente de sua ocorrência [o constrangimento] suscita uma atitude de coação nos indivíduos em seus encontros sociais de modo a evitar possíveis ações que possam ser consideradas problemáticas e contribuir para desacreditá-los socialmente. O sentimento de embaraço desempenha, portanto, um papel importante no envolvimento dos atores com valores e convenções existentes na organização social. (MARTINS; 2008, p.140)
}

Esse sentimento de embaraço (ou constrangimento) surge de um descompasso entre a fachada de um indivíduo e eventuais acontecimentos, que podem emergir durante o desenrolar de uma interação, que a contradiz.

Além dos rituais de salvamento que apresentamos aqui, Goffman (1982) fala de rituais agressivos de preservação da fachada e aponta que as pessoas fazem escolhas pelas fachadas que preservarão, que a interação falada tem suas próprias nuances e sua estrutura tem uma relação com a estrutura do eu. Mas, de qualquer forma, quando uma pessoa realiza uma preservação da sua fachada, ela estabelece um acordo tácito de preservar a dos outros, isso representa uma disposição em obedecer às regras básicas da interação social. Se ela e as outras pessoas não 
possuíssem essa socialização, a interação na maioria das situações seria uma coisa muito mais perigosa para os sentimentos e as fachadas. (GOFFMAN, 1982)

\subsection{Rituais de sucesso}

Collins (2004), ampliando o conceito de Ritual de Interação de Goffman, vai definir algumas características básicas dos rituais de interação para se tornarem rituais de sucesso.

Para que o Ritual de Interação (Rl) ocorra e seja bem-sucedido, existem alguns ingredientes que se fazem necessários: montagem do grupo (duas ou mais pessoas fisicamente reunidas), barreira para estranhos com limitação para a entrada de pessoas de fora no grupo, foco comum no qual as pessoas centram atenção em um objeto ou atividade em comum e humor compartilhado no qual elas comungam um estado de espírito comum ou uma experiência emocional.

Quando há um foco comum e um humor compartilhado, um tende a alimentar o outro criando uma intensificação e um arrastamento do grupo para a efervescência coletiva.

Como resultado, surge a solidariedade de grupo, responsável por gerar satisfação pessoal de seus membros. O grupo cria símbolos de relação social (algo semelhante ao que Durkheim chamou de 'objetos sagrados'). Então, o grupo chega ao ponto máximo de identidade, criando padrões de moralidade com os quais os membros visam garantir o respeito e com base nos quais aplicam sanções para aqueles que violam os símbolos sagrados (ícones, visuais, palavras, gestos).

Figura 2: Conjunto de processos de um ritual de interação com suas conexões e os feedbacks entre eles.

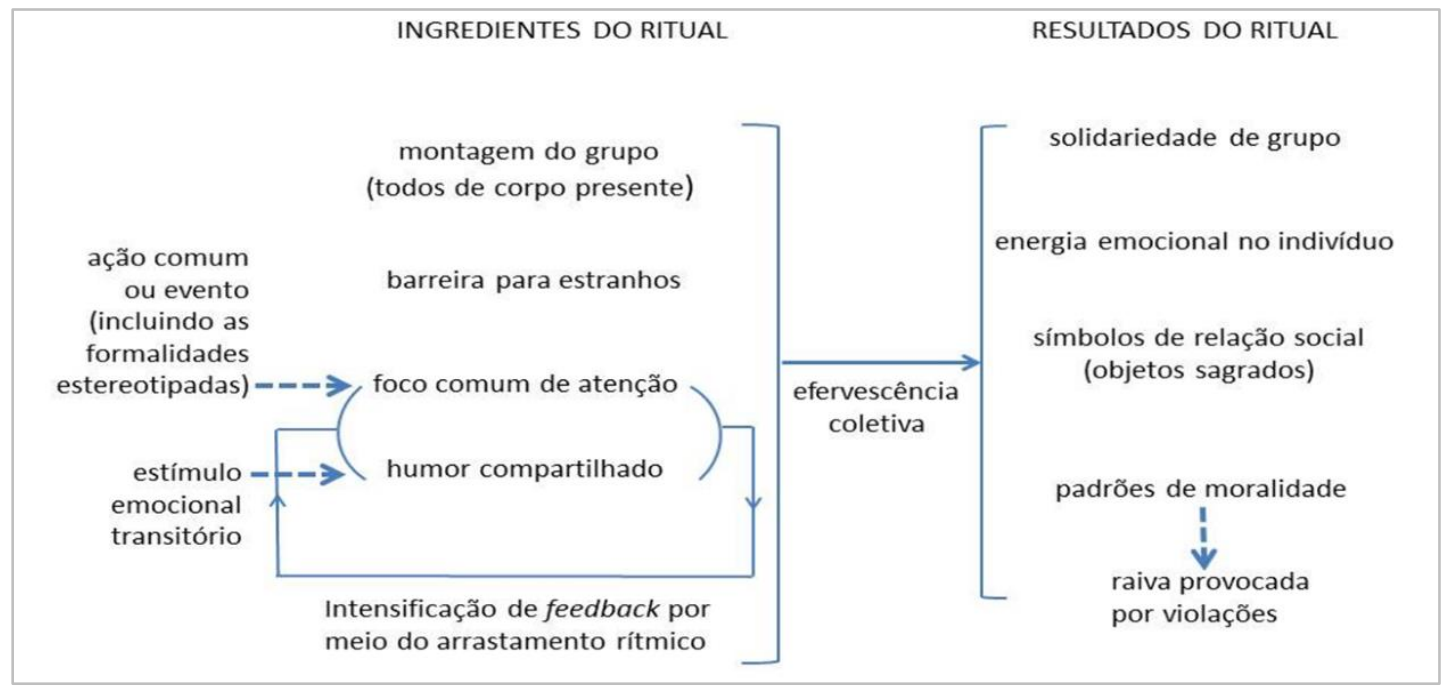

Fonte: COLLINS, Randall, 2004, p.48, tradução 
Dessa forma, um ingrediente básico para um Rl de sucesso é o que Collins (2004) chama de Energia Emocional (EE), que proporciona sentimento de confiança, alegria, força, entusiasmo e iniciativa de agir. É essa energia que vai proporcionar a intensificação do foco comum do grupo e garantir a solidariedade entre seus membros, levando-os a uma união e à busca por repetir esses rituais.

Quando os indivíduos estão com uma EE alta, o grupo atinge um Clima Emocional (CE) alto que caracteriza um ritual de sucesso.

Estudos como Tobin e Ritchie (2012), Bellocchi et al. (2013) e Tobin et al. (2013) utilizaram medidas do CE da aula por meio de atribuição de valores dentro de uma escala de 1 (muito negativo) a 5 (muito positivo), com base nessa perspectiva da valência das emoções e sua importância para a interação social, como teorizado por Collins (2004) e Turner (2007).

CE é produzido pelos processos microssociais de salas de aula que se concentram em interações sociais entre os alunos e entre o professor e os alunos. Um ponto chave de semelhança em todas as definições de CE é que ele se relaciona com o estado de excitação emocional entre membros de um grupo. (BELLOCCHI et al.; 2013, p.531, tradução nossa)

O CE pretende identificar as emoções salientes dentro de um contínuo de negativo a positivo, como apontado por Collins (1993)

As emoções, por si só, permitem atribuir valor às coisas; e assim, por sua vez, a troca não é possível a menos que os indivíduos possam atribuir valências emocionais ao longo de um continuum de positivo a negativo. (COLLINS; 1993, p.33, tradução nossa)

O ponto chave do CE é a percepção das emoções salientes no grupo, algo que pertence a uma linguagem humana básica cuja a origem é anterior à língua falada.

As emoções humanas constituem um sistema de linguagem primordial no qual os fonemas emocionais são ligados em sequências por regras implícitas de sintaxe que comunicam o afeto. (...) Ekman e Friesen (1971), Ekman et al. (1972), apontaram que a sintaxe das emoções mais primárias é universal, com talvez certos refinamentos adicionados pela cultura emocional da sociedade. Mas o ponto-chave é que os indivíduos aprendem a linguagem emocional de sua cultura, e o fazem quase imediatamente fora do útero e muito antes de começarem a aprender a linguagem auditiva de sua cultura. Essa capacidade de linguagem, como Chomsky $(1965,1980)$ tem defendido por todos esses anos, é inata; o cérebro humano é pré-conectado e receptivo para aprender a língua, pelo menos até próximo dos 11 anos de idade. Após esta idade, a aquisição de linguagem se torna muito mais difícil. (TURNER, 2007, p.82, tradução nossa)

Dessa forma, para conhecermos melhor sobre as estruturas de um grupo social ou de uma determinada cultura que se revelam nos rituais de interação (Goffman, 1982) precisamos investigar também suas emoções. 
Os rituais de interação que apresentam EE alta tendem a se repetir com alguns símbolos e com o foco comum, facilitando o surgimento de novos rituais em que o grupo permanece ligado, criando Cadeias de Rituais de Interação. (COLLINS, 2004)

Para Collins (2002), a EE está ligada ao sujeito, enquanto o CE está no grupo que interage. Quando o grupo atinge um CE alto, ocorre a efervescência coletiva, criando vínculos e a tendência em buscar repetir esses rituais.

Como as pessoas participam de diversos rituais ou cadeias de rituais de interação, o que torna uma pessoa diferente de outra são os seus encontros sociais diferentes.

Os indivíduos não se distinguem da sociedade como se eles fossem o que são mesmo sem nunca terem interagido com mais ninguém. [...] Cadeias de Rituais de Interação [...] geram suas individualidades. A particularidade do indivíduo é a particularidade do caminho social que traçou. (COLLINS, 2002, p.74, tradução nossa)

No processo educacional, em momentos nos quais o professor realiza uma intervenção didática, antes de ser a aplicação de uma metodologia didática ou a abordagem de conhecimentos científicos, ela é um encontro social em microescala. Podemos então dizer que estão ocorrendo diversos rituais de interação nesses encontros face a face. Por isso, estudá-los do ponto de vista microssocial pode nos revelar aspectos do processo educacional que as análises macro não identificam.

Ao considerarmos que o clima emocional da aula está relacionado com o envolvimento dos alunos e também com as emoções do professor e dos alunos, ponderamos ainda a forma como o professor está se relacionando com seus alunos. Assim, cabe investigar essa relação com mais proximidade.

Essa investigação precisa considerar não só a estrutura em que ocorrem as aulas e as visões do professor e do aluno sobre seus papéis, mas também os encontros em que elas ocorrem e nos quais estes sujeitos interagem, com as emoções fazendo parte intrínseca do processo (TURNER, 2007) e por isso podendo ser um grande indicador dessas interações, como explicitaremos no próximo item. 


\section{METODOLOGIA E CARACTERIZAÇÃO DA PESQUISA}

Até a década de noventa as pesquisas em sala de aula na área de ensino de ciências utilizavam uma metodologia tradicional a qual buscava, em geral, por meio da observação em sala de aula, da coleta de dados nos registros escritos dos alunos (trabalhos, provas, cadernos) e das entrevistas com professores e alunos, descrever com alguns detalhes 0 trabalho do professor e assim caracterizar como ocorria 0 processo de ensino e aprendizagem. (CARVALHO, 2005)

Essas pesquisas utilizavam bastante uma abordagem semelhante às investigações nas ciências físicas, partido de uma hipótese e fazendo estudos quantitativos. Buscavam chegar a uma conclusão sobre determinado aspecto dos alunos ou do trabalho do professor e

(...) tal como naquelas ciências [físicas e naturais], o fenômeno educacional foi estudado por muito tempo como se pudesse ser isolado, como se faz com um fenômeno físico, para uma análise acurada (...) (LÜDKE; ANDRÉ, 1986, p.3)

Uma vez que o processo de ensino e aprendizagem na sala de aula é complexo e envolve muitos aspectos, investigá-lo por meio de uma abordagem menos fechada e mais voltada a identificar aspectos salientes, parece um caminho promissor.

Para Astolfi (1993), as formas de investigações educacionais podem ser organizadas em três paradigmas: as pesquisas de viabilidade, as pesquisas por busca de significado e as pesquisas de regularidade.

As pesquisas de viabilidade que têm um caráter mais praxiológico, de forma que seus resultados permitem construir um corpus empírico de referência, capitalizando as diversas inovações postas em prática e com isso fornecendo um estado de possibilidades em uma dada situação didática, em um dado momento, de forma a situar os testes didáticos realizados nas salas de aulas em relação uns aos outros.

Nas pesquisas por busca de significado, que possui um caráter mais hermenêutico, os trabalhos consistem em ir além da narrativa crônica e imaginária de uma situação, a fim de abordar sua coerência interna e tentar entender o que está acontecendo. Nesse tipo de pesquisa, à medida que se avança na interpretação, muitas vezes se percebe a lacuna que separa as intenções e os objetivos iniciais do professor de seus modos reais de intervenção e a percepção que os alunos podem ter. Em outros casos, enfatiza a existência simultânea em sala de aula, entre 0 
professor e os alunos, ou entre grupos de alunos, de lógicas interligadas que estruturam as trocas e dão sentido a certas repetições que a análise imediata tinha considerado irrelevantes, ou às quais haviam sido dados apenas interesse anedótico. Nesse tipo de pesquisa não dispomos de uma teoria a priori para explicar as situações, e as hipóteses não podem ser refutadas diretamente, mas podem ser consideradas como um diagnóstico que demonstra a emergência de novas interpretações para as situações educacionais. De acordo com esse paradigma, a pesquisa consiste em buscar uma interpretação internamente consistente e não é dependente de um problema de verdade e de erro.

As pesquisas de regularidade, que visam a caracterização de elementos, processos, relações isoláveis, possivelmente repetíveis, usam técnicas e metodologias cujo critério de validade é a possibilidade de uma replicação dos resultados (enquanto o paradigma de pesquisa anterior se referia a ações bastante singulares, em sua especificidade difíceis de compreender), se valem muito da descrição e da experimentação, e as hipóteses aqui têm o status mais canônico como o adotado nas metodologias das 'ciências exatas'. (ASTOLFI, 1993)

Dentro da perspectiva de Astolfi (1993), nossa pesquisa se encaixa no paradigma das pesquisas por busca de significado, com abordagem fenomenológica interpretativa dentro do paradigma hermenêutico, o qual busca apreender as estruturas subjacentes dos fenômenos por métodos de intuição. Ela permite investigar novas questões para ajudar a entender o processo de mediação didática na sala de aula e assim repensar alguns aspectos sobre ele.

Adotamos uma metodologia reflexiva, na qual a pesquisa empírica tem natureza interpretativa, política e retórica e o pesquisador busca, por meio de processos constantes de indução, dedução e abdução, desenvolvidos ao longo da investigação, construir sua interpretação. (ALVESSON e SKÖLDBERG, 2009)

Esta interpretação também precisa ser vista na perspectiva de outros, além de precisar sofrer a autocrítica como intérprete e como autor. As informações e os fatos são construções do pesquisador, fruto da sua interpretação. Alvesson e Sköldberg (2009) alertam, como fez Poincaré, que os dados não falam, ou seja, o pesquisador nunca está lidando com os 'dados puros'.

Alvesson e Sköldberg (2009) apontam que as abordagens indutiva e dedutiva são formas clássicas de tratar os dados nas investigações, ambas utilizadas nas 
Ciências Humanas. A indutiva, como lembram, parte de vários casos individuais e pressupõe que uma conexão, que tenha sido observada em todos eles, seja sempre válida, envolvendo assim um salto arriscado de um conjunto de fatos únicos para uma verdade geral. (ALVESSON e SKÖLDBERG, 2009) Já a abordagem dedutiva decorre de uma regra geral e afirma que esta regra explica um único caso.

Essa abordagem é menos arriscada - ao preço de parecer presumir o que deve ser explicado: que a regra geral sempre é verdadeira, portanto também no caso atual. Além disso, na verdade não parece explicar nada, mas sim evita explicações por meio de declarações autoritárias, antes como um pai que sob estresse pode responder a uma criança curiosa: "Por que a borboleta tem asa?" "Porque todas as borboletas têm asas, querida." (ALVESSON e SKÖLDBERG; 2009, pp. 3-4, tradução nossa)

No entanto, eles lembram que além dessas duas, podemos pensar na abdução como meio de lidar com os dados da pesquisa. Para Alvesson e Sköldberg (2009), a abdução é provavelmente o método de fato utilizado nas pesquisas baseadas em estudos de casos. A abdução tem um pouco da indução e da dedução, mas não é uma simples mistura das duas, nem se reduz a elas, pois acrescenta elementos novos e específicos.

A abdução começa por uma base empírica, assim como a indução, mas não rejeita preconcepções teóricas e, nesse sentido, está mais próxima da dedução. (ALVESSON e SKÖLDBERG; 2009, p.4, tradução nossa)

Para explicar o processo de abdução, Alvesson e Sköldberg (2009), diferenciando-a da dedução e da indução, utilizam o exemplo clássico dos cisnes e suas cores.

A dedução começaria postulando que, se uma ave é um cisne, ela é branca, e então conclui que, se encontrarmos um cisne sozinho, ele é branco. A indução, primeiro conhece um cisne branco, depois outro, depois outro... e, finalmente, conclui que todos os cisnes são brancos. A abdução observaria um cisne com certa cor e, em seguida, mostra como, por exemplo, a estrutura genética do pássaro pode gerar uma certa coloração. Esse padrão subjacente explica o caso individual. (ALVESSON e SKÖLDBERG; 2009, p.5, tradução nossa)

A abdução pode ser ilustrada pelo diagnóstico médico, quando a partir dos sintomas e da percepção de que há um padrão subjacente diagnostica-se uma doença; e também pela hermenêutica e a interpretação de poesias, que requer vários elementos para que a compreendamos. A abdução tem sido utilizada como método útil para sistemas de inteligência artificial (van der Lubbe, 1993, apud ALVESSON e SKÖLDBERG, 2009)

Alvesson e Sköldberg (2009) consideram superada as discussões sobre as vantagens de utilizar os métodos quantitativos ou os qualitativos nas ciências sociais, 
e que se evitarmos a armadilha de considerar resultados quantitativos como representantes robustos e inequívocos de uma realidade 'lá fora', não há motivos para sermos antiquantitativos.

Então, a pesquisa empírica reflexiva, ou simplesmente pesquisa reflexiva, não se concentra em manusear o material empírico, mas, na medida do possível, fazer uma consideração das circunstâncias perceptiva, cognitiva, teórica, linguística, (inter)textual, política e cultural que formam o pano de fundo para as interpretações. (ALVESSON e SKÖLDBERG, 2009)

A pesquisa empírica reflexiva deve, pois, partir de uma abordagem cética sobre o que aparece ao olhar superficial sobre como a realidade funciona e ao mesmo tempo manter

a crença de que o estudo de excertos adequados (bem pensados) dessa realidade podem fornecer uma base importante para uma geração de conhecimento que abre em vez de fechar, e fornece oportunidades de compreensão ao invés de estabelecer "verdades". (ALVESSON e SKÖLDBERG; 2009, p.9, tradução nossa)

Dessa forma, Alvesson e Sköldberg (2009) apontam duas características básicas da pesquisa reflexiva: a interpretação cuidadosa e a reflexão. A primeira implica que todas as referências para os dados empíricos são resultados da interpretação.

A consideração da importância fundamental da interpretação significa que uma suposição de uma simples tese de espelhamento da relação entre "realidade" ou "fatos empíricos" e resultados de pesquisa (texto) deve ser rejeitada. A interpretação vem à frente do trabalho de pesquisa. Isso exige a maior consciência dos pressupostos teóricos, a importância da linguagem e da pré-compreensão, que constituem os principais determinantes da interpretação. (ALVESSON e SKÖLDBERG; 2009, p.8, tradução nossa)

A segunda característica, a reflexão, consiste em voltar a atenção para a pessoa do pesquisador, a comunidade de pesquisas, a sociedade como um todo, bem como a natureza do problema, da linguagem e da narrativa no contexto da pesquisa.

A reflexão sistemática em vários níveis diferentes pode dotar a interpretação com uma qualidade que constrói pesquisas empíricas de valor. A reflexão pode, no contexto da pesquisa empírica, ser definida como a interpretação da interpretação e o lançamento de uma autoexploração crítica de suas próprias interpretações sobre o material empírico (incluindo sua construção). A reflexão pode significar que consideramos consistentemente várias dimensões básicas por trás e no trabalho de interpretação, através das quais isso pode ser qualificado. (ALVESSON e SKÖLDBERG; 2009, p.9, tradução nossa) 
Alvesson e Sköldberg (2009) chamam atenção para o fato de que, nas pesquisas em ciências sociais, os dados não revelam o que está acontecendo, existindo certas interpretações que precedem a interpretação dos dados.

O fato de que a interpretação precede os dados em toda a pesquisa é algo que temos sistematicamente mantido ao longo deste livro. Pode-se falar sobre interpretações primárias (ou grosseiras), que são necessárias se quisermos evitar uma mistura de impressões sensoriais não escolhidas. (ALVESSON e SKÖLDBERG; 2009, p.287, tradução nossa)

Assim, Alvesson e Sköldberg (2009) chamam atenção também da importância de o pesquisador estar sempre se questionando sobre os dados e sua interpretação.

Em nossa pesquisa, num momento inicial, muito incipiente, tínhamos a intenção e a expectativa de encontrarmos rituais de sucesso (COLLINS, 2004) que poderiam caracterizar o engajamento dos estudantes no estudo da física.

Durante as observações não encontramos situações que pudessem ser caracterizadas com grande engajamento dos estudantes e envolvimento com a aprendizagem da física; mas pudemos trazer algumas reflexões sobre o que estava acontecendo em certos momentos que poderiam (ou não) estar criando situações indesejadas entre os estudantes.

Num primeiro momento cogitamos fazer entrevistas para tentar compreender as percepções e as emoções dos alunos naquelas situações. Mas, resolvemos adotar outro enfoque, que utilizasse as emoções como parâmetros, e que as considera como uma linguagem fundamental das interações sociais face a face (COLLINS, 2004).

Por isso, voltamos nossa atenção para as aulas gravadas, assistindo várias vezes, ao que identificamos que em alguns momentos durante abordagem de conceitos de física pelos professores em formação, algo aparentemente saiu fora da ordem ritual que vinha sendo desenvolvida.

Optamos então por verificar o clima emocional da classe (CE) para utilizar como parâmetro que poderiam ser indicadores de alterações emocionais, que poderiam estar relacionadas com algo que estava em jogo na interação dos futuros professores com os alunos.

A partir das observações e das gravações de aulas utilizamos as medidas de clima emocional (CE) da classe como heurístico (TOBIN e RITCHIE, 2012) para a busca de eventos salientes, aplicando uma investigação orientada por eventos (SEWELL, 2005) 
Durante nossas leituras e discussões no grupo de pesquisa NUPIC realizamos testes de tomada do clima emocional e suscitamos a possibilidade de utilizar pessoas de fora do processo para avaliarem o clima emocional. Embora o processo mais comum seja a autopercepção do $\mathrm{CE}$, ou seja, pedir aos próprios alunos que indiquem o clima emocional no qual estão imersos (BELLOCCHI et al., 2013), mas também já existe pesquisa com tomada do CE por inferentes externos ao contexto da aula como realizado por Tobin et al (2013). Nesse caso, pesquisares que assistiram às aulas ou às suas gravações avaliaram a carga emocional presente no ambiente. Acreditamos que pessoas sem formação em pesquisa têm as mesmas condições de estimar o clima emocional, visto ser essa uma capacidade humana.

Em nossa pesquisa, utilizamos as medidas de clima emocional avaliada por leigos, fundamentados na ideia de Turner (2007) de que, a despeito de diferenças culturais, existem emoções básicas comuns a todos os humanos, e que todos possuímos a capacidade de identificarmos essas emoções nos outros.

Adotamos essa inovação na tomada do CE por leigos por entendermos, como indicado por Turner (2007), que esta seja uma habilidade humana desenvolvida não apenas pela cultura, mas durante o processo evolutivo.

As emoções revelam tanto os fonemas quanto a sintaxe e, como uma linguagem falada,
a "linguagem das emoções" se desdobra em termos de fonemas ligados por uma
gramática. Parte dessa gramática é fortemente conectada porque certas expressões
emocionais parecem universais, particularmente aquelas que marcam as emoções
primárias (Ekman, 1973a, b, 1982, 1992a, b, c; Ekman e Friesen, 1975; Ekman et al.,
1972). A medida que nos deslocamos para elaborações de primeira e segunda ordens,
no entanto, a cultura provavelmente tem um efeito maior sobre a expressão das
emoções, assim como para a linguagem falada (já que o vocabulário e a gramática das
línguas diferem). No entanto, a "linguagem das emoções", anterior e mais primitiva, é
programada. [...] a primeira língua dos hominídeos foi a das emoções. (TURNER, 2007;
pp.11-12, tradução nossa)

Turner (2007) aponta que essa linguagem pode ser lida por outras pessoas, mesmo não participantes de uma interação, por meio dos sinais corporais.

Embora não possamos definir precisamente o que é uma emoção, pelo menos em termos genéricos, podemos ser altamente específicos sobre os estados afetivos que são evocados pela neuroanatomia humana. Os seres humanos podem experimentar esse complexo de aproximadamente cem emoções com relativa facilidade. Se você dúvida disso, desligue o som em um filme ou drama de televisão e, na maioria dos casos, você será capaz de ler as emoções expressas nos semblantes dos rostos, bem como nos movimentos e nas posturas corporais para traçar o enredo. Se você acrescentar a isso as inflexões, preenchimentos e tom de voz (como seria o caso se você assistisse a um filme em um idioma que você não conhece), você se sairia melhor em entender o que estava acontecendo. (TURNER, 2007; p.11, tradução nossa) 
Scherer (2003), fazendo uma revisão dos estudos sobre o papel da voz na expressão das emoções, mostrou que apesar de por vezes o tema haver criado controvérsias, as pesquisas, com base em um conjunto de parâmetros acústicos identificáveis experimentalmente, se mostram coerentes e indicam forte consistência no fato das emoções expressas na fala serem em grande parte detectadas com sucesso por uma variedade de populações.

Assim, nossa medida do clima emocional da classe por leigos tem seu potencial para servir de heurístico na busca de eventos salientes que estão ocorrendo durante uma abordagem conceitual de física, inclusive por não estarem focados no aspecto conceitual, mas apenas no emocional.

Por conseguinte, nossa pesquisa teve um caráter hermenêuticofenomenológico, buscando compreender aspectos do processo educacional por meio da abdução (Alvesson e Sköldberg, 2009) durante o processo de observação e análise. Em nossa investigação, nos centramos em professores em formação inicial, embora muitos já exerçam docência há algum tempo.

Para isso, nos valemos de observações e filmagens das atuações em sala de aula de professores em processo de formação, por meio de análise dos vídeos (visão para classe e visão para os professores em formação) obtidos durantes as aulas, além das anotações de campo.

Assim, investigamos situações de sala de aula, protagonizados por alunos em fase de conclusão do curso de Licenciatura em Física, que colocaram em prática o ensino de determinado tema relacionado ao respectivo ano da turma em que estavam atuando.

Escolhemos alguns episódios (com durações de 12 a 20 minutos cada) durante as abordagens didáticas pelos futuros professores ${ }^{15}$, excluindo os momentos iniciais da aula (acomodação, chamada pelo professor titular da turma, etc.) ou diálogos sobre orientações a respeito de datas de entrega de trabalhos, composições de notas, etc.

Esses episódios foram escolhidos para serem submetidos às medidas do clima emocional (CE) porque, em uma interpretação primária (ALVESSON e SKÖLDBERG, 2009), identificamos que poderia estar ocorrendo alterações emocionais e, consequentemente, nos rituais de interação (COLLINS, 2004) em algum momento durante a abordagem de conceitos da física.

\footnotetext{
${ }^{15}$ Daqui para frente, chamaremos esses futuros professores (apesar de alguns já exercerem a profissão há algum tempo), apenas de estagiários.
} 
Por meio das filmagens, apresentamos esses episódios a um grupo de voluntários e solicitamos que apontassem o clima emocional (CE) sempre que um alarme tocasse (a cada 1 ou 2 minutos).

Assim, a partir do gráfico das médias do clima emocional (CE) apontado pelo grupo de voluntários, realizamos a busca por eventos salientes expressos pelas variações do clima emocional da classe, salientes no gráfico.

Essa metodologia na tomada do clima emocional da classe já foi utilizada anteriormente por Tobin e Ritchie (2012) e Tobin et al. (2013) que realizaram avaliações do clima emocional (CE) pela equipe de pesquisadores, além de outros dados como batimentos cardíacos e alterações da voz, ao passo que outros trabalhos, como Bellocchi et al. (2013), utilizaram as indicações do clima emocional da aula apontado pelos próprios alunos.

A busca de eventos salientes já foi utilizada naqueles trabalhos, seja com base no gráfico do CE indicado pelos alunos, pelos pesquisadores, ou pelos gráficos de outros parâmetros como batimento cardíaco ou timbre de voz. Ela está fundamentada na teoria do evento de Sewell Jr (2005) e a explicamos mais detalhadamente no tópico a seguir.

\subsection{Investigação Orientada por Eventos}

A teoria do evento, proposta por Sewell Jr (2005), foi desenvolvida para ajudar a identificar e estudar eventos nas Ciências Sociais mesmo que aparentemente não façam sentido no processo histórico ou social e que parecem uma ruptura brusca. $A$ aplicação dessa metodologia nas Ciências Sociais, como a Antropologia, já vem sendo adotada e também se mostra promissora para as investigações em educação.

Sewell Jr (2005), retomando a proposta do antropólogo americano Marshal Sahlins, que após um longo debate com Gananath Obeyesekere sobre a morte do Capitão Cook pelos nativos das ilhas havaianas em 1779, sugeriu abandonar a visão dicotômica entre evento e estrutura, e considerou o evento como transformações da estrutura e que a estrutura é o resultado cumulativo de eventos passados, assim as estruturas são múltiplas e moldam o mundo à sua imagem e os eventos, que, embora sejam moldados por estruturas, transformam as estruturas que os moldaram. 
Os eventos históricos devem ser entendidos como acontecimentos que transformam estruturas. A razão pela qual os eventos constituem o que os historiadores chamam de "pontos de virada" é que de alguma forma mudam as estruturas que governam a conduta humana. Compreender e explicar um evento, portanto, é especificar que mudança estrutural ele traz e determinar como a mudança estrutural foi efetuada. (SEWELL JR; 2005, p.208, tradução nossa)

Os eventos são então um ponto importante a ser estudado para se conhecer as estruturas que estão manifestas, mas também as mudanças que estão ocorrendo.

Um evento histórico, portanto, é (1) uma sequência ramificada de ocorrências que (2) é reconhecida como notável por contemporâneos, e que (3) resulta em uma transformação durável de estruturas. (SEWELL JR; 2005, p.228, tradução nossa)

O princípio da teoria do evento constitui em voltar a atenção para eventos que se destaquem, destoem do que estava acontecendo durante o desenrolar dos acontecimentos, visto que esses fatos podem revelar mudanças que estejam ocorrendo nas estruturas que se manifestam no próprio evento.

O evento é uma parte pequena se comparada à toda a história de determinado acontecimento. Constitui-se como evento justamente por se destacar do restante da história dos acontecimentos e representa uma possível mudança de estrutura.

A temporalidade do evento reconhece o poder dos eventos na história. A vida social pode ser conceituada como sendo composta de inúmeros acontecimentos ou encontros nos quais pessoas e grupos de pessoas se envolvem na ação social. [...] Os eventos podem ser definidos como aquela subclasse relativamente rara de acontecimentos que transforma de forma significativa estruturas. Uma eventual concepção de temporalidade, portanto, é aquela que leva em conta a transformação de estruturas por eventos. (SEWELL JR, 2005, p.100, tradução nossa)

Sewell Jr (2005), destacou a importância de as estruturas serem transformadas durante um evento, podendo este ser considerado como um catalisador para a mudança individual, coletiva ou institucional (Sewell Jr, 2005)

O estudo da reprodução social, assim como o das transformações sociais cheias de acontecimentos, deve examinar as contingências locais, as dependências dos caminhos e as estruturas da conjuntura. $\mathrm{O}$ aparato conceitual necessário para explicar os eventos transformadores é igualmente necessário para explicar por que as transformações não ocorrem. (SEWELL JR; 2005, p.273, tradução nossa)

Assim, para Sewell (2005), os eventos podem estar fazendo manifestar as estruturas ou as colocando em risco e estudá-los pode nos trazer informações preciosas sobre a ação social que se desenrola no evento.

Além da contingência, Sewell Jr (2005) aponta que quando as contradições de estruturas culturais entram em choque, desencadeiam um grande fluxo de eventos, podendo gerar mudanças nas estruturas. 
Entendemos a aula como o desenrolar de uma situação ("a história da aula") e na qual estruturas de culturas diferentes entram em contado: a cultura escolar, a cultura dos alunos, a cultura do professor, a cultura científica. Nesse contexto, diversas estruturas estão se cruzando e podem surgir contingências e contradições que geram eventos os quais podem gerar a mudança das estruturas.

Assim, utilizamos a busca por eventos (Sewell Jr, 2005) desenvolvida inicialmente para as Ciências Sociais e já utilizada também por Tobin e Ritchie (2012) e Bellocchi et al. (2013) para pesquisas educacionais sobre a sala de aula.

Seleção de eventos é análogo ao uso de uma lente de zoom, e análises meso
geralmente envolvem eventos relativamente curtos, na vizinhança de dois a três
minutos. Esperamos que a pesquisa interpretativa produza um rico conjunto de
afirmações e contradições associadas que podem ser exploradas mais adiante através
de microanálises. (TOBIN e RITCHIE, 2012, p.118, tradução nossa)

Tobin e Ritchie (2012) analisaram as emoções durante uma atividade desenvolvida por uma professora em seu primeiro ano de trabalho, durante a qual os alunos ficaram muito envolvidos e agitados. Os pesquisadores assistiram ao vídeo da aula da professora e atribuíram notas de 1 a 5 para o clima emocional da aula, sendo 1 para 'muito negativo', 2 para 'negativo', 3 para 'neutro', 4 para 'positivo' e 5 para 'muito positivo'.

Bellocchi et al. (2013), em uma atividade extra no fim do semestre, com 14 alunos voluntários (de uma classe com 16), realizaram debates sobre questões relacionadas a socio-scientific issues (SSI) (alterações climáticas, alimentos geneticamente modificados, uso da energia nuclear) e, por meio de um clicker, atribuíram pontuação à suas emoções nos momentos em que um sinal sonoro indicava.

Em nossa pesquisa, a partir das observações e das anotações de campo, das gravações em vídeos das aulas, escolhemos alguns episódios (12 a 20 min) em que os estagiários estavam desenvolvendo algum procedimento didático para, dentro desses episódios, encontrar algum evento saliente manifesto pela variação do clima emocional da aula. Esses vídeos recortados das aulas foram apresentados aos leigos para pontuarem o CE em intervalos de 1 ou 2 minutos.

Em um momento anterior a essa tomada do CE por leigos, durante as observações in loco, estávamos na busca de momentos que poderiam estar criando CE positivo alto e que poderiam estar relacionados com energia emocional (EE) alta, 
que caracteriza rituais de sucesso (COLLINS, 2004) e que, talvez pudesse estar criando cadeias de rituais de interação que envolvessem os estudantes no estudo da física. Dessa forma poderíamos ter pistas do que ajuda a envolver emocionalmente e criar engajamento dos estudantes no estudo da Física.

Porém, durante os acompanhamentos das aulas dos estagiários em campo, presenciamos algumas situações durante abordagem de conceitos de física nas quais pareciam que os estagiários estavam em uma situação de prosseguir com uma linha ou acabavam realizando uma mudança brusca e que deixava a classe eufórica ou, em outros casos, atônita.

Assim, assistimos a cerca de duas dezenas de aulas para verificar possíveis momentos semelhantes a esses. A partir daí, fizemos a escolha de dez trechos de aulas, que chamamos de episódios (dois deles são trechos da mesma aula) e focamos nossa atenção para tentar compreender o que acontecia.

Uma vez que esses momentos se constituem em encontros sociais face a face, buscamos conhecer se estava ocorrendo alguma alteração emocional nessa interação, utilizando a Investigação Orientada por Eventos como já utilizada por Tobin e Ritchie (2012) e Bellocchi et al. (2013), por meio da medida do clima emocional (CE) da classe, porém utilizando o apontamento por leigos, alienados do que estava acontecendo; apenas orientados a pontuarem sobre o CE em intervalos marcados. ${ }^{16}$

Assim, estudamos os episódios de sala de aula utilizando o clima emocional como heurístico indicador principal dos processos de interação mediados pelas emoções. Os eventos foram direcionados com base no clima emocional avaliado por pessoas externas ao grupo de pesquisa e aos participantes das interações em sala de aula (professores e alunos). A Investigação Orientada por Eventos visou construir significados sobre os eventos escolhidos.

É importante reforçar o fato de que em nossa pesquisa utilizamos o CE da aula para identificar os eventos. No entanto, outros indicadores poderiam ter sido utilizados como os gráficos dos batimentos cardíacos e da oxigenação, fornecidos por oxímetros. ${ }^{17}$

\footnotetext{
${ }^{16}$ No Apêndice, incluímos um estudo para validação dessa forma de medir o CE da classe. Inicialmente solicitamos aos alunos de uma classe que pontuassem sobre o CE e posteriormente apresentamos 0 mesmo vídeo da aula a leigos, não participantes da aula, para compararmos as duas indicações com a finalidade de verificarmos a possibilidade de utilização da medida do CE por leigos.

17 Particularmente, acreditamos que a medida do CE, por estar mais diretamente relacionada ao processo de interação social, tem maior potencial com relação às emoções compartilhadas e a
} 
Como aponta Turner (2007), a capacidade humana de ler emoções expressas pelas pessoas através das feições e das posturas corporais é anterior ao desenvolvimento da língua falada. Assim, tanto uma criança de 12 anos quanto um idoso de 70 anos possuem essa capacidade podendo, portanto, indicar o clima emocional da aula.

$\mathrm{Na}$ busca por eventos salientes o que importa são as variações do clima emocional. Assim, as medidas absolutas feitas por cada um dos avaliadores externos, sejam eles crianças ou idosos, homens ou mulheres, são irrelevantes, na medida em que as variações independem delas.

5.2. Método de verificação do clima emocional da aula

Optamos por medir o Clima Emocional (CE) dos episódios por meio da avaliação feita por pessoas comuns, não participantes da aula e não pesquisadores. Para a atribuição do Clima Emocional (CE), os leigos não haviam participado nem assistido aos vídeos das aulas anteriormente e foram orientados momentos antes de assistirem aos trechos dos vídeos das aulas que foram gravados com a câmera mostrando os alunos, sobre a escala de atribuição, sobre observarem o clima emocional da classe, não se preocupando com o que estava sendo abordado pelos estagiários e sem focarem em nenhum aluno especifico, mas no geral da classe.

Foi-Ihes solicitado atribuírem 1 para um clima emocional 'muito negativo', 2 para 'negativo', 3 para 'neutro', 4 para 'positivo' e 5 para 'muito positivo'; seguindo uma metodologia semelhante a utilizada por Tobin e Ritchie (2012); com o diferencial de que escolhemos pessoas comuns, familiares do pesquisador, para pontuarem, ao invés de pesquisadores ou os próprios alunos, como já realizados pelas duas pesquisas já citadas.

Os voluntários que realizaram pontuação do CE são bem variados: uma adolescente estudante do ensino fundamental, uma funcionária pública com formação

identificação dos rituais de interação. Outra possibilidade de utilização como heurísticos, seria cruzarmos essas fontes para buscarmos relações entre elas e o que estava acontecendo. Mas, tendo também em vista que cada uma pode revelar situações muito distintas, optamos em usar apenas a tomada do CE da classe. 
superior, uma aposentada e apenas com ensino fundamental, e dois homens (um funcionário público e outro profissional liberal, ambos com formação superior).

Foi orientado aos voluntários que analisassem o clima emocional a cada momento em que soasse um sinal sonoro mostrado previamente para eles e programado para tocar em intervalos idênticos ao longo dos vídeos; e foi enfatizado que não precisavam se preocupar com o que os estagiários estavam ensinando, mas tão somente prestarem atenção nas feições e posturas gerais dos alunos (sem nunca se focarem em nenhum aluno em particular).

Com as indicações dos seis voluntários, foi realizada a média dos valores para cada ponto dos vídeos e a partir daí construído o gráfico para cada vídeo, que mostra as variações do $C E$, permitindo que se veja desde o perfil geral daquela aula, os pontos altos e baixos do CE e onde ocorreram as maiores variações ou estabilidades no valor do CE. O CE da aula, obtido pela média simples dos valores atribuídos, parece ter um padrão independentemente dos avaliadores, estando mesmo relacionado com a capacidade humana de perceber os estados emocionais, como constatamos em nossas tomadas dos CEs das aulas e validado em outra observação que confrontou as indicações dos alunos participantes da aula e a avaliação por leigos, que apresentamos no Apêndice deste trabalho.

A partir do CE da aula, buscamos os eventos salientes nos Rituais de Interação nas aulas selecionadas e a partir daí, analisamos com mais detalhes alguns eventos em termos das emoções expressas pelos estagiários.

Dessa forma, buscamos por eventos salientes para um maior aprofundamento na análise desses eventos, seguindo uma investigação orientada por eventos. (SEWELL JR, 2005)

Foram apresentados aos leigos dez episódios e descrevemos a seguir sete episódios com as identificações de seus respectivos candidatos a eventos. Mas, nos concentraremos mais em dois eventos (no episódio 1 e no episódio 6) que apresentaram as duas maiores variações do clima emocional da aula.

Solicitamos aos leigos pontuarem sobre como eles acham que estava o clima emocional da classe naquele momento (ou próximo dele) em que tocou o sinal sonoro. Foi solicitado que avaliassem de acordo com suas percepções gerais sobre o clima emocional da classe, pelas posturas, expressões, vozes, sem fixarem em nenhum aluno específico nem se preocuparem com o que estava sendo abordado. 
Uma câmera foi colocada filmando os leigos enquanto assistiam aos vídeos e solicitado que não olhassem para as avaliações dos outros nem falassem sobre o que estavam achando; que se assim o fizessem, invalidariam as medidas, pois não havia 'certo' ou 'errado' ou 'que todos pensam', mas uma média que só seria válida se ninguém se baseasse na indicação dos outros.

\subsection{Caracterização do campo de investigação}

Durante o ano de 2016, alunos das Disciplinas Metodologia do Ensino de Física I e II, do Instituto de Física da Universidade de São Paulo, futuros formandos em Licenciatura em Física, realizaram estágios em escolas da rede pública estadual na região da cidade de São Paulo, os quais fazem parte das atividades e estudos junto à disciplina.

Os alunos trabalharam em grupos de quatro componentes, nas Disciplinas de Metodologia do Ensino de Física I e II. Em diversas atividades ao longo do ano e nas práticas em sala de aula desenvolviam, em uma sequência de três aulas, em duplas, algum tema da Física pertinente ao currículo do ano escolar da turma em que praticaram a aula na escola colaboradora do programa de estágios.

A escola é de porte médio, oferece Ensino Fundamental (anos finais), Ensino Médio e Educação de Jovens e Adultos (EJA) - Fundamental e Médio.

Nossa pesquisa focou a interação dos estagiários nas aulas da Educação de Jovens e Adultos, do Ensino Médio, período noturno da escola, cujos alunos são muitas vezes trabalhadores durante o dia. As turmas de EJA da escola são compostas por alunos que já possuem 15 anos (para o Ensino Fundamental) e 18 anos (para o Ensino Médio) e que não concluíram educação básica regular anteriormente. As classes observadas são constituídas por alunos de várias idades acima da mínima exigida em lei. No estado de SP, as turmas são chamadas de 'Termos', pois cada ano escolar é concluído em 6 (seis) meses. Logo, os alunos concluem o Ensino Médio em um ano e meio.

Realizamos filmagens das aulas das turmas de EJA (Ensino Médio) ao longo do ano de 2016 e observações in loco nos meses de setembro a novembro do mesmo ano. 
As observações das aulas in loco, no segundo semestre, nos levaram a assistir e analisar também as aulas filmadas no primeiro semestre. O objetivo era encontrar eventos que representassem aspectos salientes da prática dos estagiários na interação com os alunos, identificar situações e rituais de interação já detectados no segundo semestre, sobretudo os que colocavam em evidência momentos de abordagem de conceitos da física.

Utilizamos a investigação orientada por eventos para encontrar aspectos emocionais que podem estar manifestando estruturas que se cruzam durante 0 processo educacional e que podem dar início a alguma mudança de estrutura da aula.

Trata-se de observar aspectos salientes em um nível meso ou micro e analisálos para procurar uma compreensão macro do fenômeno social a que se pretende estudar, no caso, da sala de aula. De maneira prática, um evento é identificado a posteriori, quando se olha para o conjunto dos acontecimentos e se identifica o mesmo como algo saliente no desenrolar dos acontecimentos. No nosso caso, o evento está relacionado a um evento emocional, que se destaca do restante dos acontecimentos por ter apresentado uma variação alta no clima emocional da classe e no qual centramos nosso foco de análise.

A partir das anotações de campo como as conversas de corredor sobre o que os estagiários falavam de como foi tentar ensinar determinado conceito ou conhecimento da física e das gravações em vídeos, identificamos que em determinadas situações de aulas poderia estar acontecendo algo que o estagiário de alguma forma mudou o curso do que pretendia ou do que se propunha, mas não sabíamos bem o que. E nesses momentos parecia que os alunos estavam apáticos ou eufóricos. Então, resolvemos estudar esses momentos em que os estagiários abordavam os conceitos de física.

Por vezes, parecia que o estagiário se via entre duas possibilidades: seguir uma linha que tem o preceito de levar aos alunos conhecimentos científicos e que segue determinados procedimentos didáticos ou seguir uma linha que atende a um compromisso pessoal que leva (ou pode levá-lo) a subverter os propósitos do processo de ensino e aprendizagem. E nesses momentos, algo poderia estar mudando no processo de interação dos estagiários com a classe. E possivelmente, as emoções poderiam revelar algo sobre esses momentos.

Sabemos que existe uma crença muito difundida entre os estudantes de que a física é difícil, de que os estudantes não gostam da física. Possivelmente esses 
valores e crenças estão associado com aspectos emocionais ao se abordar os conteúdos de física. É praticamente impossível que alguém goste de algo que não entende, e não é possível que alguém entenda aquilo que não gosta (pois não se interessa). Esse parece muitas vezes ser o dilema do ensino de física em quase todas as escolas de educação básica. Alguns alunos podem até se interessar por entender a física. Mas, em geral, a grande maioria 'detesta física'.

Desta forma, estudar os aspectos emocionais e o processo de interação social que ocorre durante abordagens de conceitos de física pode nos ajudar a entender melhor a relação dos estudantes com a física e entende o que Ihes aproxima (ou afasta) ao se falar da física.

\subsection{Retomando o objetivo}

Em nossa investigação da atuação dos estagiários na sala de aula, percebemos que o estagiário parece muitas vezes se ver entre dois 'compromissos': um oriundo de sua formação sobre ser professor de Física, com os conhecimentos técnicos tanto da Física que pretende ensinar quanto das metodologias didáticas que pretende aplicar ou mesmo de sua formação ambiente (anterior a formação para professor); e outro oriundo de seu 'eu', enquanto participante de um encontro social face a face.

Em alguns momentos após a aula, que não estavam sendo filmados, apenas acompanhado pelo pesquisador, ocorreram situações em que os estagiários demonstraram a preocupação maior com o 'domínio do conteúdo' ou o 'domínio da classe'; como quando um estagiário ao término da aula disse que havia percebido que não tinha falado corretamente determinado conceito físico, mas que "Não podia voltar a trás", sob pena de "perder a moral" com os alunos.

Então, resolvermos estudar os momentos em que esses estagiários estavam abordando determinado conceito físico nas suas aulas práticas, do ponto de vista microssociológico dos rituais de interação.

Assim, nossa investigação teve por objetivo analisar os Rituais de Interação (RI) durante momentos em que as aulas estavam se 'desenrolando' com os 
estagiários explicando/desenvolvendo algum conhecimento da Física, em busca de eventos que pudessem revelar algo sobre o ritual em jogo.

Durante nossa análise dos eventos, pudemos perceber que as variações emocionais reveladas nos gráficos do CE de um dos episódios estavam relacionadas com um momento em que já havíamos percebido que o estagiário se viu dividido entre explicar o conceito físico e as dúvidas dos alunos ou colocar em jogo rituais de interação dos encontros face a face; em outros episódios, só percebemos que coisa parecida aconteceu quando focamos nosso olhar nos pontos em que houve grande variação no $C E$.

Dessa forma, essas situações nos levaram ao delineamento da nossa questão inicial, e a partir daí, buscamos analisar esses eventos, à luz da teoria dos rituais de interação (Collins, 2004; Goffman, 1982), para identificarmos que rituais de interação os estagiários estavam colocando em jogo durante suas abordagens de física e percebemos que eles tinham uma forte relação com os rituais de salvamento da fachada. (Goffman, 1982) 


\section{ANÁLISES DOS DADOS}

Durante nossas observações de campo, na escola onde os estagiários realizavam suas aulas em duplas, foi possível perceber um clima variável durante as aulas. Por vezes, alguns momentos eram caracterizados por apatia dos alunos, outras por agitação sem muito envolvimento e outros com envolvimento maior ou menor, mesmo que por vezes com silêncio e atenção aos estagiários. Algumas aulas foram marcadas por aparentarem um alto grau de envolvimento dos alunos e outras com pouco; ou ainda por ter acontecido alguma situação de certo desconforto aparente ou questionamento dos alunos. Dessa forma, pelas observações em classe, nos pareciam que algumas situações poderiam ser investigadas do ponto de vista emocional da interação face a face da sala de aula.

Buscamos verificar o que pode ter ocorrido em cada episódio que tenha produzido alguma alteração emocional que revele algo importante sobre as interações na classe. Como afirmamos mais acima, optamos por utilizar, como heurístico para indicar esses eventos, as medidas do clima emocional da classe. As variações emocionais fazem parte dos encontros face-a-face (GOFFMAN, 1982) e podem produzir diversas alterações nos quatro sistemas emocionais corporais - sistema nervoso autônomo, neurotransmissores, endócrino e músculo-esquelético. De acordo com Goffman (1982), essas alterações podem ser lidas pelos demais participantes do encontro em microescala e mesmo por pessoas de fora do ritual de interação. $O$ fato dessas alterações poderem ser lidas por pessoas externas ao ritual também é coerente com a ideia de que a capacidade humana de detectar as emoções por meio das expressões corporais tenha sido desenvolvida evolutivamente como uma habilidade do cérebro humano; tendo, portanto, bases biológicas e não apenas culturais (TURNER, 2003).

Às vezes, alguns alunos pareciam focados em concluir uma determinada atividade, geralmente em uma folha; a qual seria entregue para o professor de outra disciplina, de outra aula posterior. Algumas vezes em que isso ocorria, os alunos que estavam copiando determinada atividade pareciam totalmente alheios ao que acontecia na sala. Porém, houve momentos também em que os alunos que estavam fazendo tal tarefa pareciam, ao mesmo tempo, preocupados em terminá-la, mas também curiosos em relação ao que estava acontecendo na aula. 
Em determinada conversa com alguns dos estagiários, eles relataram que gostariam de receber mais atenção por parte dos alunos e mais envolvimento. Em virtude disso, solicitaram ao professor de Física, responsável pela turma, que pontuasse as atividades aplicadas na sala para que os alunos as valorizassem. E de fato o professor passou a realizar em toda aula, após a chamada, uma conversa com a classe em que falava sobre a importância do trabalho desempenhado pelos estagiários e que tudo que eles aplicassem valeria nota.

A despeito das características comuns a muitas escolas de educação básica, o trabalho dos estagiários foi marcado por uma preparação das aulas e das atividades que aplicariam nas classes. Em algumas aulas foram trabalhados problemas abertos (principalmente no primeiro semestre), em outras, situações mais tradicionais com aulas demonstrativas ou expositivas.

Durante nossas observações, entretanto, foi possível perceber também que em alguns momentos os estagiários estiveram em situações didáticas ou conceituais cujas expressões pareciam indicar que pararam por um instante antes de agir. Esses momentos parecem ter algo de especial sobre o que está acontecendo no ritual de interação do estagiário com os alunos e talvez nas estruturas da aula.

Desse modo, realizamos inicialmente análises de dez episódios, focando em partes da aula em que algo parece ter acontecido enquanto os estagiários abordavam conhecimentos da física, dessa forma, às vezes excluímos partes do início, do meio ou da parte final da aula; ou seja, momentos menos centrados na mediação de conteúdo e onde a classe estava foca nas demandas mais operacionais da aula e não havia muita troca de conhecimentos de física. Assim, procuramos excluir os trechos que registram a chegada da turma, realização da chamada, saída da classe e interrupções de alguém externo ao contexto da aula. Posto isso, os dez vídeos analisados tiveram de 12 a 26 minutos de duração. ${ }^{18}$ Para os vídeos de 12 min os voluntários indicaram o clima emocional em intervalos de 1 minuto e para os que duravam mais de vinte minutos, utilizamos intervalos de 2 minutos.

A partir daí, por meio da medida do CE, utilizado como heurístico, buscamos momentos dentro dos episódios que são fortes candidatos a eventos (TOBIN; RITCHIE, 2012) e apresentamos a seguir a análise dos eventos encontrados em sete dos dez episódios.

\footnotetext{
18 Isso dá uma ideia da proporção entre a mediação didático de conteúdos e a mediação operacional numa aula de 45 minutos.
} 
Fundamentados em Turner (2007), acreditamos que, não sendo as linguagens das emoções privilégios de algumas pessoas, mas sim comuns a todos os seres humanos e, pelo menos as emoções básicas, independentes da cultura (EKMAN, 1992), pessoas alheias ao processo podem fornecer bons dados sobre as variações do clima emocional da aula.

A partir das observações in loco e das análises das filmagens, fizemos a tomada do Clima Emocional (CE) da aula, apresentando os episódios escolhidos para que um grupo de voluntários (seis pessoas) de várias faixas etárias (1 menina de 12 anos, três mulheres - de 30, 50 e 70 anos, dois homens - de 46 e 50 anos), que assistiram aos episódios e atribuíram uma nota de 1 a 5 ao CE.

Dessa forma, fizemos alguns estudos de casos e analisamos com mais detalhes eventos salientes a partir do clima emocional que revelaram alterações emocionais que evidenciaram situações em que surgiram aquela escolha em se manter no ritual ou seguir o preceito didático ou mesmo o rigor conceitual, bem como analisamos os gestos expressos pelos estagiários para esses dois casos particulares revelados pela medida do CE: um em que essa escolha desestabilizou uma estrutura relacionada à abordagem pedagógica e outro em que a estrutura de conceitos físicos pode ter sido modificada.

As observações in loco serviram para conhecermos os estagiários, a escola, os alunos e o processo educacional que estava ocorrendo. Também serviram para conhecermos outras falas dos estagiários sobre as interações que realizaram com os alunos. E um fator que foi por vezes observado é que os estagiários muitas vezes apresentavam uma natural preocupação em estabelecer um quadro no qual estavam com o domínio não apenas dos conhecimentos teóricos da física como a aplicação desses conhecimentos para uma explicação focada em problemas que, como thes foi solicitado e trouxeram para os alunos, são de natureza aberta, que dependendo da situação podem estar relacionados a diversos aspectos e conceitos físicos para serem compreendidos ou explicados.

Um exemplo ocorreu quando um dos estagiários, no corredor, após a aula que ele e seu colega trabalharam na escola, falou que fez uma escolha ruim para explicar a corrente elétrica para os alunos ao utilizar analogia com água em um cano, que seria melhor ter utilizado analogia com o trânsito, com fluxo de veículos. Disse que havia percebido isso na hora, quando começou a utilizar a analogia com a água, mas que 
pensou "Agora vai essa, não posso fraquejar, não posso perder a moral. Mas seria melhor a analogia com fluxo de carros."

A partir das observações in loco, começamos a delinear nossa pesquisa, num constante ir e vir, para entender o que poderia estar acontecendo em certos momentos. Como várias vezes parecia que estava relacionado ao domínio da classe ou a uma forma como o conteúdo ou o conceito estava sendo abordado, e observarmos que às vezes a classe ficava como que atônita, outras, eufórica, optamos por investigar esses aspectos do ponto de vista das emoções presentes na interação entre os estagiários e os alunos.

Escolhemos os episódios em que poderiam estar ocorrendo situações que alteraram as emoções tanto dos estagiários como dos alunos. Como as emoções dos alunos deve refletir como eles estão recebendo as informações sobre aqueles conceitos físicos, resolvemos buscar a medida do clima emocional da classe, como já utilizado por Tobin e Ritchie (2012).

Fundamentados em Turner (2003), inferimos que não seria necessário títulos de mestre ou doutor para identificar o clima emocional numa escala de 1 a 5 (de muito negativo a muito positivo), pois esta capacidade é uma capacidade humana, e resolvemos fazer tomadas do CE por leigos.

Alguns dos episódios foram incluídos porque suspeitamos que tenha acontecido alguma alteração na relação didática ou social entre os estagiários e os alunos pela forma como apresentaram o conceito físico, outros não havia muita suspeita específica, mas aparentemente poderia ter alterado algo na interação.

Como alterações na interação face a face possuem forte relação com as emoções (COLLINS, 2004), consideramos pertinente a busca por eventos (SEWELL, 2005) por meio de medidas do clima emocional da classe (TOBIN; RITCHIE, 2012)

Como abordamos anteriormente, apesar de muitas vezes serem utilizadas como sinônimo, em nosso trabalho emoção e sentimento não são consideradas a mesma coisa. E sendo as emoções reações internas que duram frações de segundos, elas se caracterizam por não terem sido filtradas por outros aspectos que os sujeitos gostariam de modificar ou criar em relação a um encontro face a face que já ocorreu. As emoções, por serem uma linguagem humana primária e estarem presentes em todos os encontros sociais (TURNER, 2007), são a cola que mantém viva a sociedade (COLLINS, 2004). Por isso, investigar as emoções em determinadas situações como quando o estagiário se vê entre duas escolhas tais como salvar a sua fachada ou 
seguir os preceitos conceituais da Física e das metodologias de ensino, pode nos ajudar a entender melhor como as estruturas se manifestam nos rituais e assim, servir de base para promover um ensino que coloque em ação as estruturas que se pretende, tais como as estruturas das abordagens didáticas inovadoras e dos conceitos pertinentes à cultura científica.

\subsection{Episódio $1^{19}$}

O episódio 1 (Figura 3) refere-se a uma aula realizada na turma do $3^{\circ}$ Termo na qual o estagiário Fabiano ${ }^{20}$ e o estagiário Adriano realizaram uma dinâmica com problema aberto, sobre o chuveiro elétrico.

Figura 3 - Gráfico das médias do clima emocional do Episódio 1

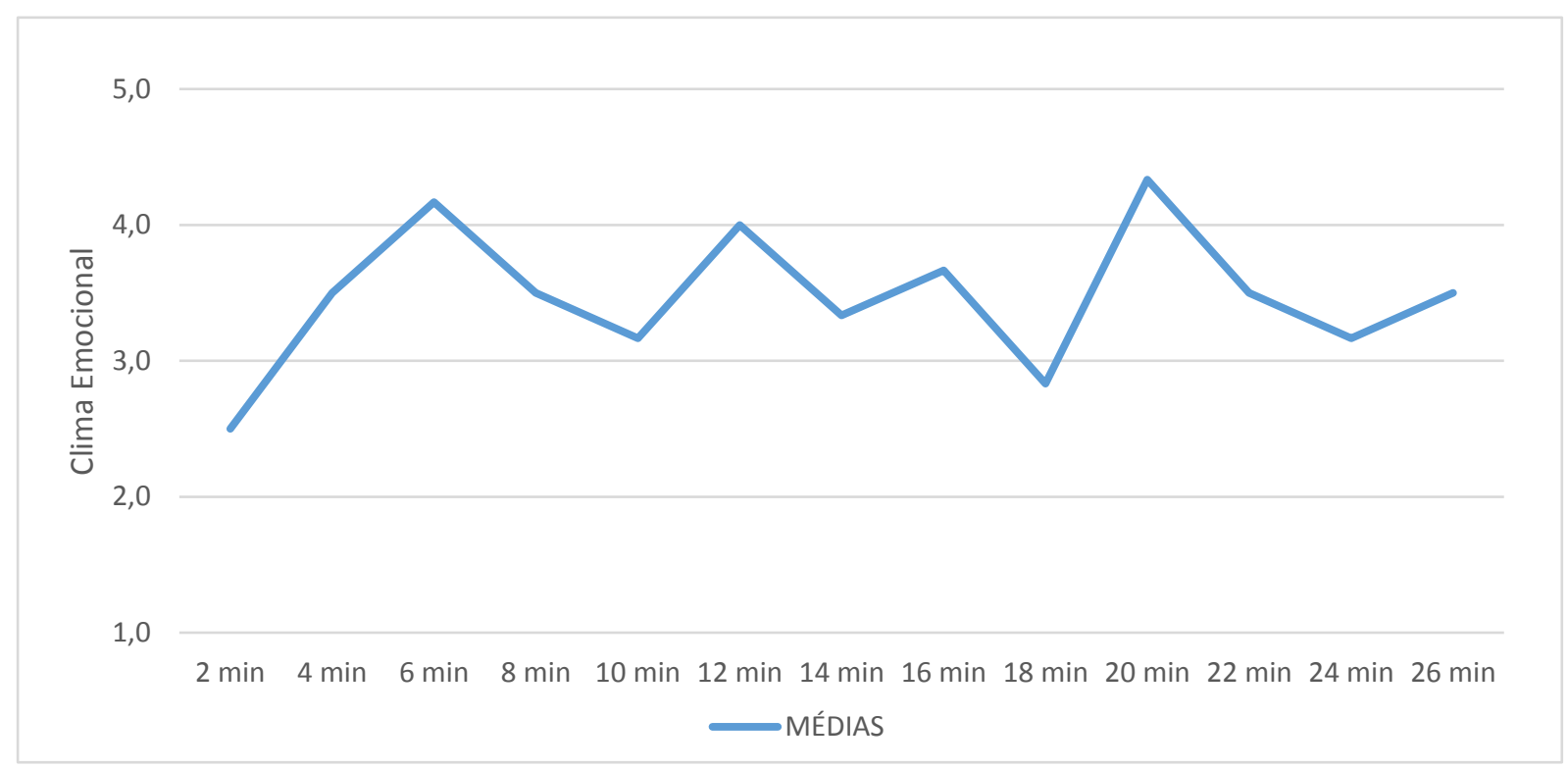

Os estagiários partiram de uma problematização para os alunos, questionando o que seria relevante considerar na hora de escolher um chuveiro elétrico para adquirir.

O episódio 1 tem duração de 26 min e o CE foi medido a cada 2 min. Seu início corresponde ao momento logo após os alunos terem se sentado e os estagiários se

\footnotetext{
${ }^{19}$ Nesse episódio e no episódio 6 ocorreram os dois eventos com as duas maiores variações do clima emocional (CE) de todas as 121 indicações mensuradas em 10 episódios para os quais foram apontados o CE em intervalos de 1 ou 2 minutos.

${ }^{20}$ Todos os nomes apresentados aqui são fictícios.
} 
apresentado. $O$ instante inicial que os voluntários assistiram e pontuaram o CE foi quando o estagiário Adriano inicia a abordagem da aula, perguntado se tem algum eletricista na classe (ao que enfatizou: "Homem ou mulher.") e solicita que os alunos os ajudem com os conhecimentos práticos que possuem. Apesar dos alunos terem entrado rapidamente na sala, nesse momento havia se passado cerca de 4 min desde que os primeiros alunos começaram a entrar na sala e havia ainda um ou outro aluno adentrando a sala.

Nos instantes 6 min e 20 min temos picos do CE, precedidos por uma alta variação do $C E$.

Até $\mathrm{o}$ instante $6 \mathrm{~min}$, os estagiários estavam levantando os conhecimentos prévios dos estudantes e a participação da classe estava bastante intensa, com os alunos falando de suas experiências, seus conhecimentos, dois alunos chamam atenção para o fato de ser importante considerar a qualidade da instalação elétrica.

Por outro lado, a partir do instante 6 min, o estagiário Adriano avisa que agora irá fazer uma análise mais do ponto de vista da Física. Os estagiários começam a explicar que no cotidiano chamamos de resistência, mas que para a Física o correto é resistor, e os alunos passam a ficar bem quietos e atentos às explicações dos estagiários. Aqui, como já apontado em pesquisas anteriores, o CE tende a diminuir em momentos que os estagiários utilizam falas quase como monólogos.

O intervalo entre $18 \mathrm{~min}$ e $24 \mathrm{~min}$ se apresenta como um forte candidato a evento saliente em termos do $\mathrm{CE}$. E de fato, esse trecho não apenas foi o que ocorreu a maior variação do $\mathrm{CE}$ desse episódio como o maior entre todos os dez episódios.

Aos $20 \mathrm{~min}$, os alunos expressaram fortes reações de surpresa após o estagiário Adriano relatar sua experiência pessoal a respeito do chuveiro de sua casa que queimou após ele fazer a instalação, e passam a fazer afirmações sobre o estagiário ter feito a ligação de forma errada.

Os alunos estavam negando o que o estagiário explicou sobre a ligação do chuveiro em sua casa e pareciam irrequietos e alguns até eufóricos.

Nesse ponto, o CE não só teve uma alta repentina, como também houve uma queda muito rápida em seguida - algo pouco comum em todos os dez episódios de aulas que medimos o CE.

As alterações do CE entre o intervalo de $18 \mathrm{~min}$ até $24 \mathrm{~min}$, com uma forte subida seguida de forte descida nos revelaram uma forte variação do CE que o coloca 
como um possível evento e por isso voltamos nossa atenção para compreender o que se passou nesse momento.

Podemos perceber nas transcrições dos diálogos (APÊNDICE A) que a reação dos alunos foi intensa, pois iniciam uma contestação de forma veemente à afirmação do estagiário de que o chuveiro queimou porque, por ser verão, a água já vinha mais quente do encanamento.

O fato dos alunos não aceitarem o exemplo dado pelo estagiário Adriano sobre o chuveiro que queimou após a instalação revela vários aspectos do RI que está em jogo, perceptíveis pela sua postura, trocas de olhares com o estagiário Fabiano, posição da mão para trás (GOFFMAN, 1982). Nas linhas 20 a 22 (APÊNDICE A), podemos verificar a busca de esconder o constrangimento: "O sorriso fixo, o riso vazio nervoso, as mãos ocupadas, o olhar para o chão que esconde a expressão dos olhos, tudo isso tornou-se conhecido como sinais para ocultar o constrangimento" (GOFFMAN, 1982; p.102)

Inicialmente, os alunos demonstraram seus conhecimentos práticos, revelando que o estagiário não teve o cuidado devido ao ligar o chuveiro elétrico, já que o correto seria ligar primeiramente na posição fria. Contudo, o estagiário relutou em aceitar esses conhecimentos que os alunos trouxeram e conduziu o RI para um salvamento da sua fachada (GOFFMAN, 1982). Esse ritual, como aponta Goffman (1982) não é necessariamente (e provavelmente não o é) consciente, mas envolve as emoções como linguagem da interação.

É como se o estagiário estivesse entre duas escolhas (mesmo inconscientes): salvar a fachada (da linha que tomou para si quando se colocou como possuidor de conhecimentos sobre instalação elétrica) ou seguir um ritual em que leva em consideração os conhecimentos e a objeção apresentados pelos alunos.

Porém, para salvar a sua fachada, precisará manter também a dos alunos (que ele próprio aceitou como possuidores de conhecimentos práticos e sobre instalação). Isso corroborado em momentos nos quais estagiário afirma "Tudo que vocês estão falando, de certa forma, tá correto" (linha 54, APÊNDICE A) e também no episódio final de sua fala ao dizer “...da próxima vez, como uns de... como alguns de vocês falaram... quando eu trocar de novo... é mais fácil eu colocar na... temperatura morna... não vou ter uma demanda tão alta de corrente elétrica. Tudo bem?. 
Afirmando, assim, que os alunos teriam dito para ligar na posição morna (fala que não ocorreu).

Essa opção de buscar uma resposta que não contradiga a dele, estagiário, e a dos alunos se mostra uma tentativa de salvar a sua fachada sem comprometer a dos alunos (GOFFMAN, 1982), já que não tem nenhum respaldo com o que de fato aconteceu, nem explicação lógica ou física. Vale lembrar que, de acordo com o próprio raciocínio do estagiário, se o problema fosse a demanda de corrente para a água mais quente, então seria melhor ligar direto na posição 'frio' e não na posição 'morno', como ele propôs. Porém, a explicação dos alunos está fundamentada nas orientações presentes nos manuais de instalação que vêm junto com os chuveiros elétricos e que muitos conhecem devido às experiências acumuladas em instalar o aparelho em suas casas.

Ainda durante esse evento, podemos perceber que o estagiário Fabiano (linhas 63 e 65) e também um dos alunos (linha 64) realizaram a cooperação para o salvamento da fachada do estagiário Adriano, dando deixas sobre a temperatura baixa em Campos do Jordão, em contraste com a do chuveiro do estagiário que queimou em um dia de verão (janeiro, segundo o estagiário Adriano).

Assim, conclui-se que o estagiário salvou a sua fachada e a dos alunos, apesar de subverter os conhecimentos da física e desconsiderar o dos alunos que possuem um conhecimento prático sobre o tema e que está de acordo com os conhecimentos da física.

Além disso, o estagiário não seguiu sua própria proposição do início da aula, na qual se propôs a considerar os conhecimentos dos alunos, mesmo eles não possuindo conhecimentos mais elaborados da física.

Como podemos perceber, esse ritual de salvamento não criou um RI de sucesso (COLLINS, 2004) que poderia levar ao surgimento de pertença aos alunos e estimulá-los a estudar o tema e até mesmo levar ao surgimento de cadeias de rituais de interação (COLLINS, 2004), em torno do assunto abordado em sala, para outras aulas. Mas, garantiu uma manutenção do encontro face a face dentro dos parâmetros da sociabilidade dos indivíduos presentes mutuamente (GOFFMAN, 1982).

Apesar dos estagiários afirmarem no início da aula, e em outros momentos, que considerariam as experiências dos alunos, que alguns poderiam saber mais sobre eletricidade do que os próprios estagiários, não foi isso o que ocorreu na prática. Ao contrário, mostrou-se muito fortemente o valor e o papel de uma estrutura em que 
esquemas de ação (o que pode ser considerado, o que está correto, quem detém o conhecimento, etc.) são controlados pelo estagiário. (SEWELL JR, 2005)

O ritual de salvamento (GOFFMAN, 1982) que o estagiário utilizou revela também a estrutura do professor (no caso, o estagiário) detentor do conhecimento sendo preservada. Aqui, fazemos um paralelo com outra situação que ocorreu em uma aula com o estagiário Euclides e o estagiário Vagner. O estagiário Vagner fez uma analogia entre água, carro e torneiras com o circuito elétrico, comparando a torneira com os resistores. Ao final, fora da aula, no corredor, enquanto conversávamos com os estagiários, o estagiário Vagner falou que fez uma escolha ruim para a analogia e disse que seria melhor usar trânsito, fluxo de carros. Ele afirmou que começou a fazer a analogia com a água e lembrou que seria melhor a outra analogia, mas que pensou: “Agora vai. Não posso fraquejar. Não posso perder a moral". E reafirmou que seria melhor a analogia com fluxo de carros.

Goffman (1982) aponta que o sentimento de embaraço é revelado por enrubescimento, gaguejar, voz estranhamente aguda ou grave, rebaixamento dos olhos, cabeça curvada, mãos postas para trás das costas, dedos mexendo nas roupas ou torcendo entre si, incoerência da ideia expressa na fala. Veja-se, por exemplo, na linha 43 (APÊNDICE A), como o estagiário Adriano muda sua postura ao ver sua fachada ameaçada.

As estruturas que estão em jogo em uma aula de Física são múltiplas, se interpõe e se cruzam (SEWELL JR, 2005), mas parece que a fachada que sustenta a estrutura dominante das práticas educacionais que relutam em serem modificadas são mesmo sagradas (GOFFMAN, 1982) e acabam prevalecendo na maioria das vezes, mesmo que se tenha de abandonar os preceitos didáticos ou subverter um conceito científico.

Como aponta Goffman (1982), ao dizer algo, o orador se abre à possibilidade de que os receptores o insultem não prestando atenção nele ou pensando que ele é atrevido, tolo ou ofensivo pelo que disse; por isso, ele estará comprometido com a necessidade de empreender ações para salvar a fachada.

Não se trata de uma questão ética ou moral, mas antes de uma natureza humana comum a todos e presente no encontro social, em todas as culturas (GOFFMAN, 1982). 
Em virtude disso, entendemos que para que um professor realize práticas inovadoras, focadas nos conhecimentos da Física e primadas por abordagens didáticas que considere o conhecimento e o processo de aprendizagem dos alunos, temos que ajudá-lo a compreender melhor o que ele coloca em prática numa aula. Para isso, entendemos que seja importante que os professores (e da mesma forma, os estagiários) tenham a oportunidades de assistir às suas aulas para poderem olhar de fora do ritual ao qual estiveram inseridos, de forma a contribuir para que realizem processos metacognitivos. Talvez assim possam desenvolver habilidades de construir rituais de interação que incorporem estruturas inovadoras de ensino e aprendizagem e evitem processos nos quais subvertam o que eles mesmos se propuseram a colocar em prática.

Analisamos também a entrevista concedida pelos estagiários ao professor responsável pela disciplina de Metodologia do Ensino de Física com os estagiários após a aula. Durante a entrevista o estagiário Adriano volta a citar seu exemplo e afirma ser por causa da água quente da rua (em um dia de verão) que demandou mais corrente e fez o disjuntor queimar. Nesse momento, ele é interrompido pelo estagiário Júlio que afirma o mesmo que os alunos, dizendo que é preciso encher primeiro a câmara de água do chuveiro para depois ligar a eletricidade. Nesse momento, o estagiário Adriano diz, aparentemente meio embaraçado, que tinha feito isso.

Assim, a forte alteração do CE nesse episódio, percebida por estranhos ao momento da aula e que não possuem conhecimentos sobre o que estava sendo trabalhado na aula ${ }^{21}$, mostra que algo ao nível emocional que é parte intrínseca do ritual de interação, estava em jogo naquele momento em que o estagiário estava com a sua fachada em risco. (GOFFMAN, 1982) Por isso, Goffman (1982) afirma que o aspecto estrutural da fala é afetado pois, para a pessoa, "seu objetivo é salvar a fachada; seu efeito é salvar a situação".

Os rituais de interação presentes nesse evento nos mostram, como aponta Goffman (1982), essa tendência da pessoa de preservar a sua fachada, junto com o acordo tácito de ajudar as outras a preservarem a delas, representa sua disposição em observar as regras básicas da interação social.

\footnotetext{
${ }^{21}$ Ao final da tomada do CE por leigos para esse episódio, perguntamos aos voluntários se haviam notado alguma coisa diferente em algum momento do vídeo e eles afirmaram que nada perceberam, que 'não estavam entendendo nada do que estava sendo trabalhado na aula', que estavam olhando apenas para os alunos para ver como estava o clima emocional, como solicitado no início.
} 


\subsection{Episódios 2 e 3}

Os dois episódios representam trechos da mesma aula, realizada pelos estagiários Arnaldo e Abel. O episódio 2 representa um momento no início da aula em que os estagiários estavam apresentando uma retomada da matéria sobre calor e temperatura, fazendo explicações de conceitos, sempre procurando ser engraçados por meio de piadinhas curtas. O episódio 3 ocorre na mesma aula, quando os estagiários estavam realizando demonstrações com balão com água e balão com ar e um isqueiro que era aceso junto aos balões. Em alguns momentos desse episódio os estagiários estavam fazendo a demonstração e em outros sentavam nas carteiras entre os alunos e realizavam uma espécie de bate-papo com os alunos.

Para os voluntários que assistiram aos vídeos dos episódios, fizemos a inversão temporal dos dois trechos para testar as atribuições de CE. Ao final, foi perguntado aos 6 voluntários que apontaram o CE sobre se notaram algo diferente em relação aos dois vídeos e ninguém citou sobre o fato de que o primeiro que assistiram ser do final da aula e o segundo da parte inicial; quando foi dito para eles o que foi feito, continuaram afirmando que não perceberam, que acharam que era outra aula com os mesmos estagiários.

O episódio 2 (Figura 4) está na parte inicial da aula, e começa quando os estagiários estão anotando coisas na lousa e os alunos estão entrando na sala rapidamente. E começam a abordagem antes mesmo de todos se acomodarem. A medida do CE no instante 5 minutos nos mostra que este é um forte candidato a evento, pois é o momento em que está ocorrendo o mais alto nível para o CE desse episódio e também onde ocorreu a maior variação em relação à medida anterior.

Figura 4 - Gráfico das médias do clima emocional do Episódio 2

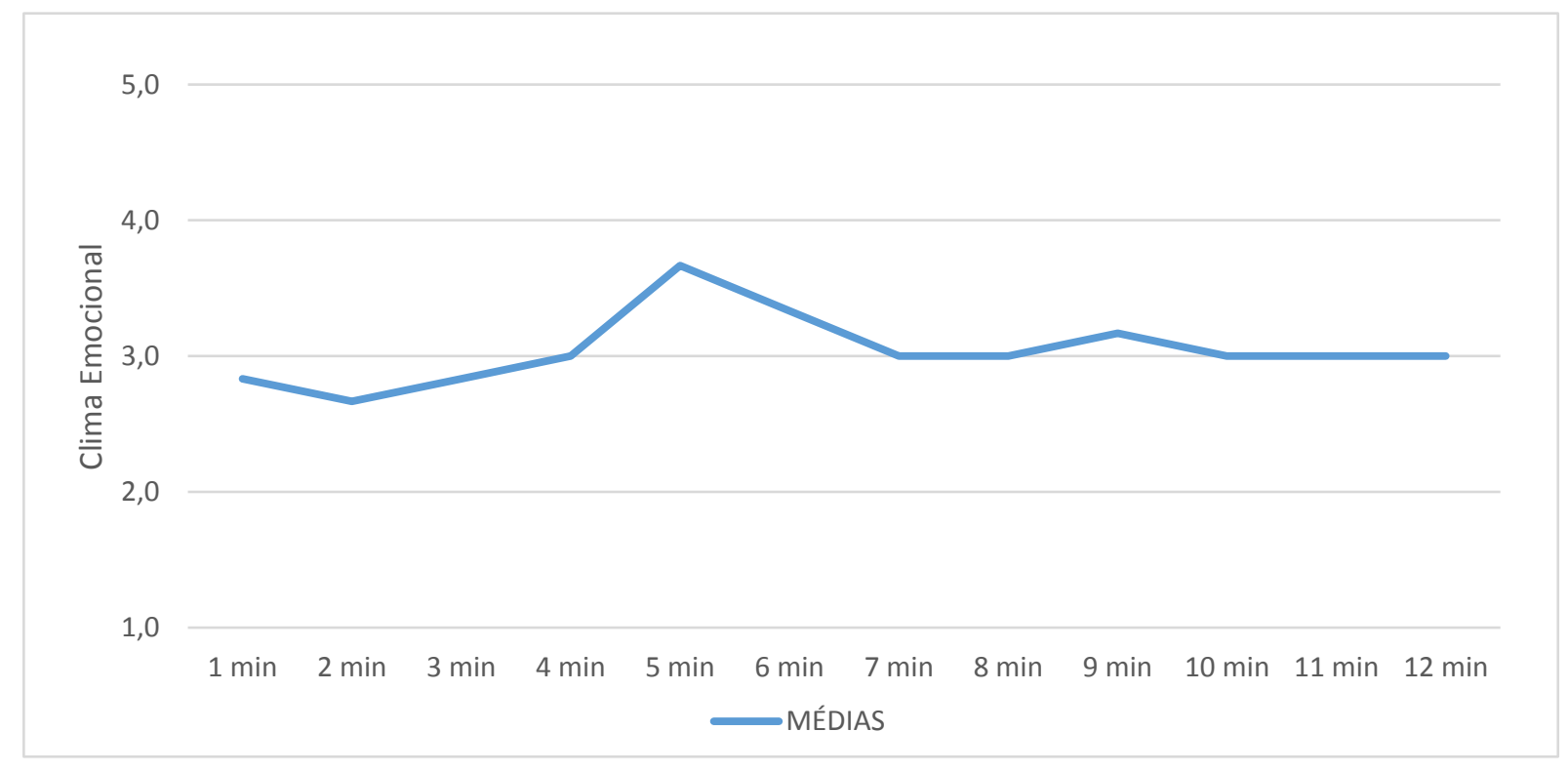


Vale lembrar que esses estagiários são bem brincalhões com os alunos (o que já era conhecido por eles), fazem bastante piadas curtas (às vezes chulas) e alguns alunos acham graça mostrando apenas sorriso ou pequenas risadas aqui ou ali.

Nas proximidades do instante 5 min (entre 4 min 40 s a 5 min07s) os estagiários realizam uma explicação sobre o calor com diversos comentários que fizeram os alunos rirem bastante, bem acima do que em outros momentos. A classe começa a rir bastante quando o estagiário Arnaldo, fazendo uma retomada do conceito de calor, diz que quando temos dois corpos, um é o quente e o outro o frio, aponta para 0 estagiário Abel quando se refere ao corpo frio. Nesse momento, muitos alunos fazem diversas brincadeiras com os estagiários, dizendo que "Você é o quente!" (risadas) e coisas parecidas. O nível de risadas é bem alto.

Em seguida (no instante $5 \mathrm{~min} 08 \mathrm{~s}$ ) enquanto os alunos estão rindo e falando sobre a piada, o estagiário Arnaldo interrompe e 'pega uma deixa' de uma aluna que diz não entender e começa a perguntar quem não estava na aula passada, e retomam a explicação diminuindo bastante as risadas. A partir desse ponto o estagiário Arnaldo começa a dar exemplos sobre troca de calor, e busca sanar as dúvidas dos alunos quanto a compreensão do conceito físico.

O CE só volta a ter um sutil aumento no instante 9min. Próximo a esse momento, o estagiário Arnaldo faz uma dança para mostrar que as moléculas estão mais agitadas, ou noutras palavras suas, "mais animadas", causando risadas não tão intensas nem por tantos segundos (de 8min50s a 8min56s) quanto no momento do evento anterior. Mas, o CE permanece a grande parte do tempo neutro $(3,0)$, mostrando que risadas causadas pelas piadas dos estagiários, por si só não são suficientes para criar EE alta (COLLINS, 2004)

O episódio 3 (Figura 5) é uma parte no fim na aula em que os estagiários apresentaram algumas demonstrações e os alunos estão bem atentos, demonstrando foco nas demonstrações apresentadas e participando; observa-se um clima de descontração entre os estagiários e os alunos quase formando um grande círculo. Em alguns momentos o estagiário Abel está sentado em uma das primeiras carteiras da sala e há vários alunos também sentados nas carteiras, em outros, estão fazendo demonstrações com balões e fogo. Mas, agora os estagiários quase não fazem mais piadas. Os estagiários fazem demonstrações e lançam perguntas como se estivessem em um bate-papo e não em uma aula formal. Possivelmente, por esses motivos, o CE 
ficou na maior parte do tempo levemente acima de 3 , mas não apresenta nenhum evento a ser considerado.

Figura 5 - Gráfico das médias do clima emocional do Episódio 3

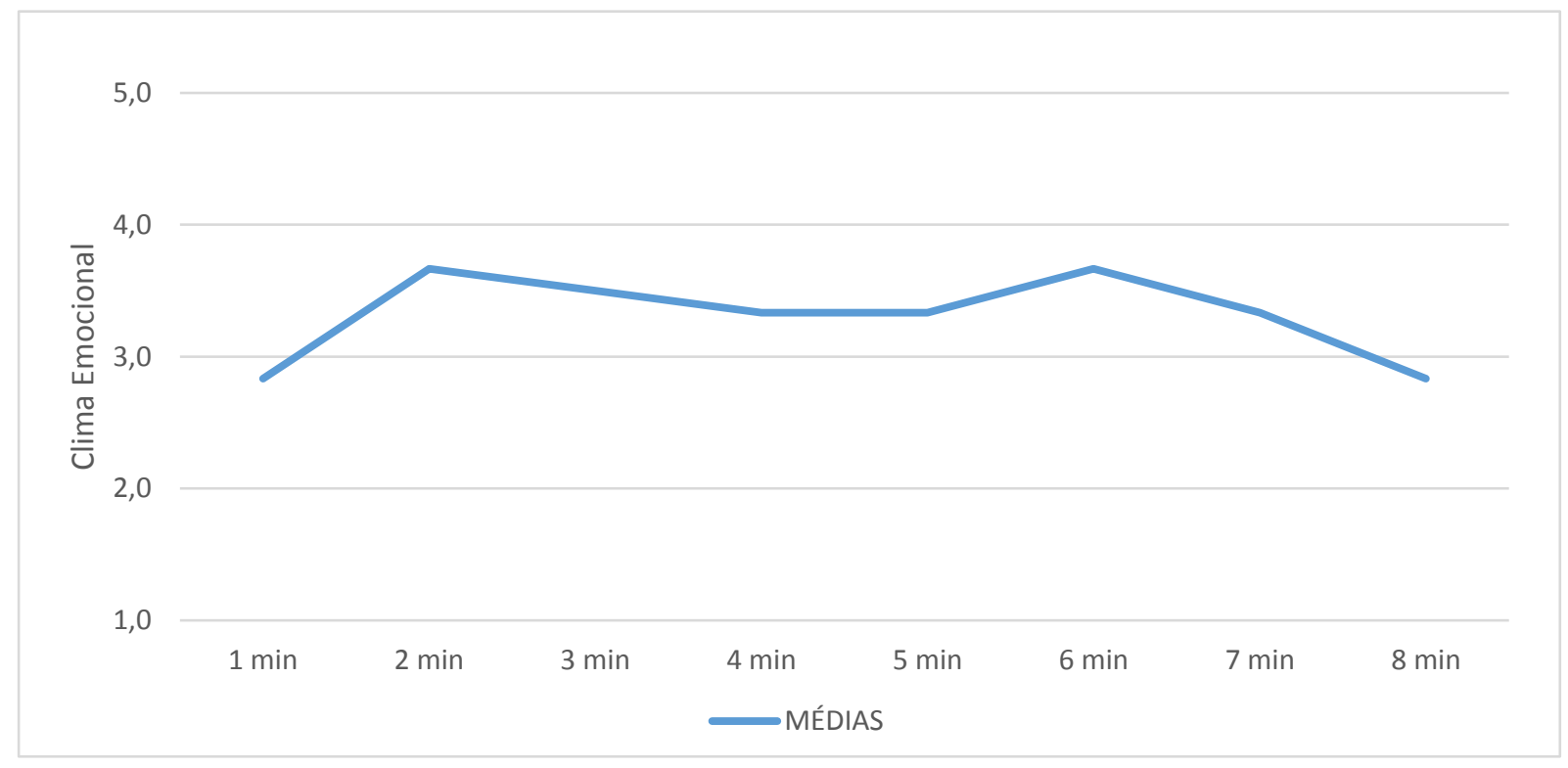

Poderíamos apenas apontar um possível evento: próximo ao instante 2 min (Figura 5) os dois estagiários pegaram um isqueiro e uma bexiga cada (o estagiário Abel a bexiga só com ar e o estagiário Arnaldo a bexiga cheia de água). O estagiário Abel foi para uma carteira no canto próximo das janelas, ficando entre os alunos, enquanto o estagiário Arnaldo ficou à frente. Porém, os alunos pareciam ter percebido o que aconteceria (possível estouro da bexiga), algumas alunas demonstraram preocupação, porém o clima observado foi de descontração, seguido de diversos risos, e seguiu a maior parte do episódio assim.

No instante 6 min, o estagiário Arnaldo preparou uma demonstração em que colocaria fogo. Os alunos parecem excitados, falantes e rindo, fazendo comentários do tipo: "para aquecer o resto de ontesdontê".

Os momentos em que os alunos estavam mais atentos, houve um CE positivo, próximo dos 3,5 pontos de média. $E$ nos dois momentos citados (2 min e 6 min) o CE passou por leves picos, que não estão associados a perda da fachada.

Nesses dois episódios é perceptível que um experimento que atraiu a atenção dos alunos e os manteve focados e participativos (episódio 3) produziu um CE relativamente alto por mais tempo, apesar de não haver tantas piadas como no 
episódio 2, no qual, nos momentos em que ocorrem piadas, o CE até aumentou, mas não se sustentou em nível mais alto, caindo em seguida.

\subsection{Episódios 4 e 5}

Esses episódios são partes da mesma aula que foi conduzida pela estagiária Gisele e pelo estagiário Maurício em uma turma de 3ำ Termo.

O episódio 4 (Figura 6) corresponde a um momento de retomada da aula pelos estagiários (após serem interrompidos pelo professor titular da classe que veio fazer chamada e dar uns recados para os alunos) de suas explicações no momento anterior dos primeiros minutos da aula, que estavam retomando conceitos trabalhados em aulas anteriores.

O CE ficou entre 3 e 4 , mostrando que não teve pontos de clima negativos, mas também sem muita efervescência.

Entre os instantes 3 min e 5 min a estagiária Gisele coloca na lousa a Lei de Ohm, permanecendo alguns momentos de costas para os alunos, inicia questionamentos que não trazem retornos dos alunos, como o que é a letra ômega, o que é resistência ou resistor, etc. A maioria dos alunos já não estão mais focados nos estagiários e passam a conversar entre si sobre assuntos alheios a aula. Os que continuam prestando atenção demonstram um semblante fixo e sem reações, sem lançar perguntas ou responder aos questionamentos colocados pelos estagiários. Novamente, é perceptível como já enfatizado em outros episódios e em pesquisas anteriores já citadas, que momentos em que os estagiários falam coisas muito técnicas e de pouca proximidade do universo dos alunos, parecendo uma palestra, corresponde a baixos níveis de CE.

Por outro lado, os alunos estão mais participativos do $7 \mathrm{~min}$ em diante. Próximo ao instante $8 \mathrm{~min}$ em diante os estagiários passam a fazer explicações utilizando uma bexiga de festa, atritando-a no cabelo da estagiária Gisele.

Mas, o candidato a evento está entre os instantes 6 min e 7 min por ter sido o intervalo em que ocorreu a maior variação do CE durante um minuto, dentre todos os intervalos em que foram feitas medidas de CE nesse episódio.

Voltando-nos para esse intervalo, é perceptível que existem lacunas ou erros conceituais na explanação dos estagiários sobre a causa de a existência de campo 
elétrico em volta do fio estar relacionada à ionização do ar e ainda a dependência de elétrons saindo do fio desencapado, como foi o exemplo seguido pelos estagiários para justificar o campo em volta do fio.

A explanação dos estagiários parece estar misturando explicações sobre ionização do ar, campo elétrico gerado por cargas e campo magnético gerado por cargas em movimento. $E$ a insegurança deles pode ter refletido no $C E$ da classe.

Próximo do 6 min, a estagiária Gisele começou a falar sobre o campo elétrico, dizendo que "o fio vai gerar uma coisa que... [esfrega uma mão na outra] que também tem o nome de elétrico...". E faz a seguinte pergunta: "Vocês sabem o que é?", para a qual um aluno responde: "Campo.", e a estagiária aponta para esse aluno e diz [acenando com a cabeça um 'sim']: "Campo... campo elétrico." E continua: "E aí, para entender isso melhor..." [coça a cabeça várias vezes, faz pausa e coça novamente a cabeça, enquanto olha para o estagiário Maurício].

Aqui, como aponta Goffman (1982), gestos como balbucios, gaguejar, uma voz estranhamente aguda ou grave, a fala entrecortada, suor, piscadelas, tremor nas mãos, movimentos hesitantes ou vacilantes, gestos forçados e não naturais, a mão ocupada, revelam o constrangimento. Em casos de embaraço leve, esses alvoroços visíveis e invisíveis ocorrem, mas de forma menos perceptível. (GOFFMAN, 1982; p.97) De acordo com Goffman (1982), esses gestos, na tentativa de ocultar o constrangimento se complementam com outros apontados por Lord Chesterfield, tais como: levar o dedo ao nariz, coçar a cabeça, girar o chapéu. ${ }^{22}$

Então, a estagiária Gisele [olhando para o estagiário Maurício e coçando a cabeça] sugere aos alunos imaginarem um fio desencapado percorrido por corrente elétrica e pergunta: "O que vai acontecer?", ao que uma aluna responde: "Vai tomar choque!". A estagiária Gisele faz gestos mostrando o fio percorrido por elétrons e dizendo que no ar também tem elétrons, mas que a gente não sente choque. Ao que a aluna complementa: "Os elétrons vão sair do fio", "Isso ...vai acontecer a ionização dos elétrons do ar ... a ionização dos elétrons que estão soltos, que ... no ambiente, no ar em si ..." [Estagiária Gisele olha para suas anotações, baixa a cabeça e diminui o tom da voz, fica de costas para a classe fazendo anotações soltas na lousa]. Nesse momento, o estagiário Maurício, gesticulando para mostrar o fio e os elétrons,

22 Letters of Lord Chesterfield to His Son. Nova York: E. P. Dutton \& Co, 1929, p.80. Apud: GOFFMAN, 1982; p.102. 
complementa: "Exatamente! Basicamente, o que acontece gente..., quando você tem a corrente elétrica passando pelo fio, o ar que está em volta daquele fio [gesticula mostrando o fio com uma mão e com a outra circulando o fio], daquela região, próxima ao fio, ele começa a receber essas... [um aluno complementa: cargas], essas pequenas cargas, esses elétrons que estão escapando. Então, essa região em volta, que a gente fala que está ionizada, que gera esse fenômeno que a gente chama de campo elétrico."

Figura 6 - Gráfico das médias do clima emocional do Episódio 4

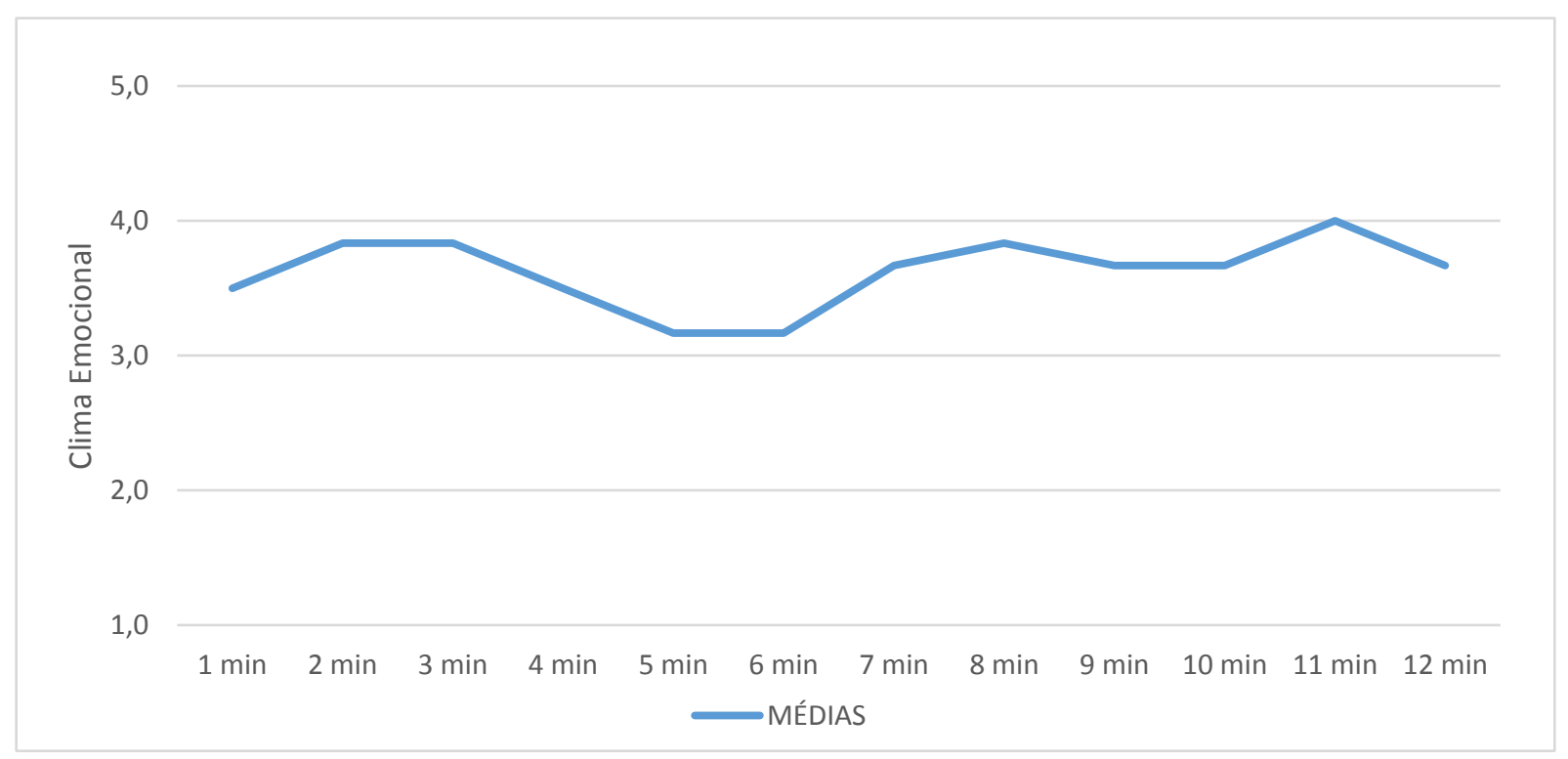

Percebemos aqui um ritual de salvamento da fachada. Não sabemos ao certo se a estagiária Gisele não sabia dar a explicação física ou se, tendo dado as explicações equivocadas de que os elétrons do fio saem e ionizam o ar, e também que a corrente elétrica no fio criaria um campo elétrico em volta do fio, mas parece ter se dado conta durante a explicação e realizado um ritual de aprumo (GOFFMAN, 1982), quando o mais adequado do ponto de vista do ensino da física seria um ritual corretivo.

No instante 11 min, o CE nesse episódio alcançou o ponto máximo, com média de 4 para o CE. Além do fato de que desde o instante $7 \mathrm{~min}$ as participações dos alunos tenham amentado consideravelmente e os estagiários estavam fazendo comentários engraçados e experimentos com uma bexiga de festa passando no cabelo dos alunos, nesse momento 11 min o estagiário Maurício estava segurando a 
bexiga que a estagiária Gisele e ele haviam atritado sobre o cabelo de um aluno, fazendo-o parecer arrepiado. Há algumas risadas na classe.

O episódio 5 (Figura 7) ocorreu na mesma aula e trata-se de uma parte em que os estagiários transitaram da explicação com um aparelho exemplificador que levaram para a classe (motor de liquidificador), até próximo dos $4 \mathrm{~min}$, para uma parte em que estavam mais voltados para ficar explicando os conceitos físicos, alternando entre a fala de um e a fala do outro estagiário, lendo o que haviam anotado, escrevendo alguma coisa curta na lousa (a partir dos 5 min em diante).

Figura 7 - Gráfico das médias do clima emocional do Episódio 5

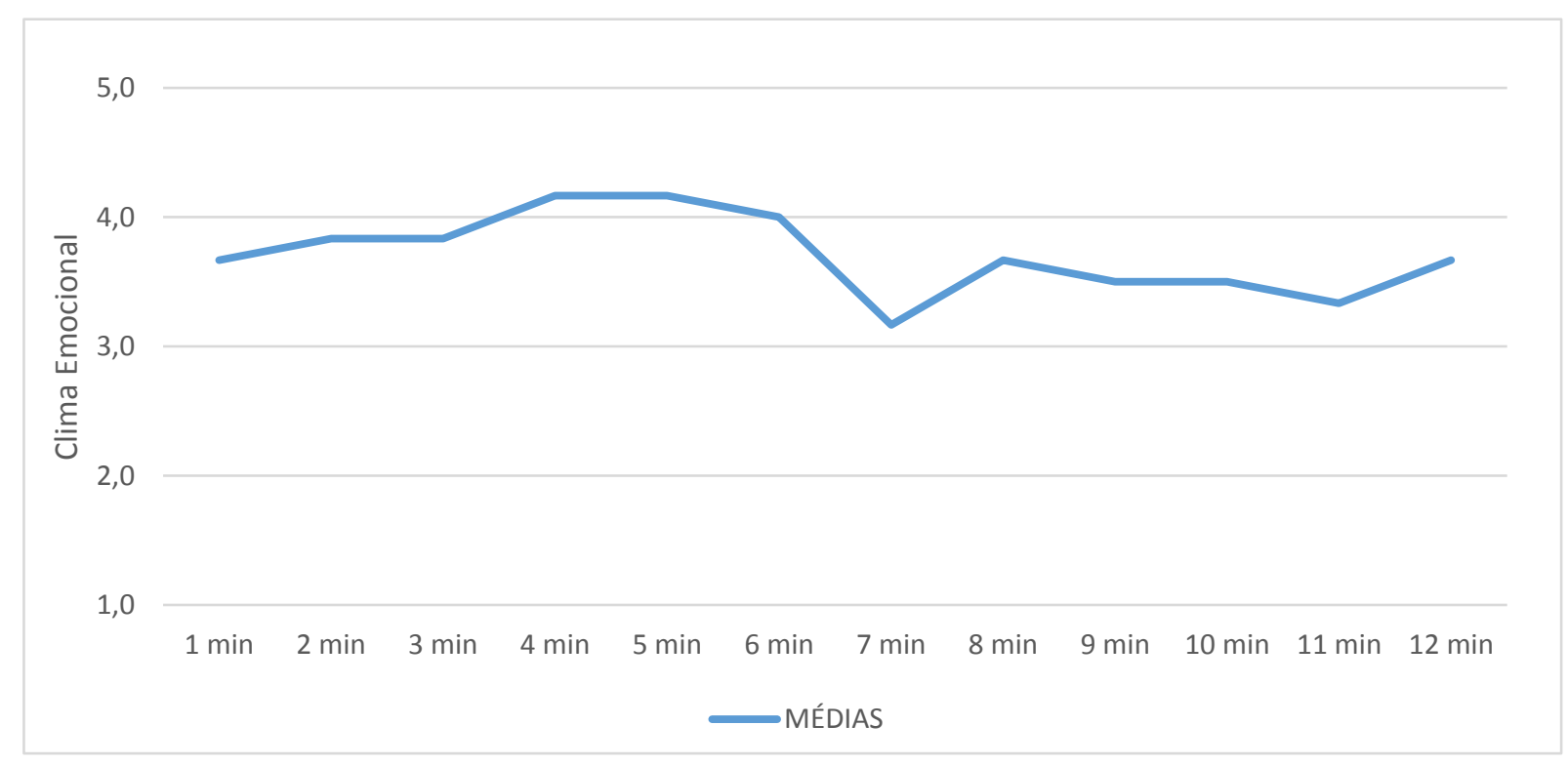

Nesse episódio, a estagiária Gisele inicia avisando que "agora a coisa vai ficar legal!", e apresenta um liquidificador desmontado que mostra para a classe e vai explicando seu funcionamento (até o instante 6 min, quando o estagiário Maurício toma a palavra e depois os estagiários intercalam as falas de ambos).

Do instante $6 \mathrm{~min}$ ao $7 \mathrm{~min}$, o estagiário Maurício faz uma explanação síntese do que eles querem mostrar, da relação entre eletricidade e magnetismo, do papel das usinas hidrelétricas, etc. De uma fala mais corrida e que tenta explicar o fenômeno da indução eletromagnética para os alunos, tentando não utilizar termos muito técnicos. 


\subsection{Episódio 6}

O episódio 6 (Figura 8) refere-se a aula da estagiária Adelaide e do estagiário Fernando, realizada em uma turma de $2^{\circ}$ Termo, onde estavam abordando conceitos de calor e temperatura, troca de calor e equação da calorimetria.

Um fator que chama atenção com relação ao CE da aula é de que, apesar das pequenas oscilações no $\mathrm{CE}$, ele apresenta uma tendência geral de queda durante todo o episódio, e apresenta a maior queda de 5 min para 6 min, mostrando ser esse um candidato a evento.

Figura 8 - Gráfico das médias do clima emocional do Episódio 6

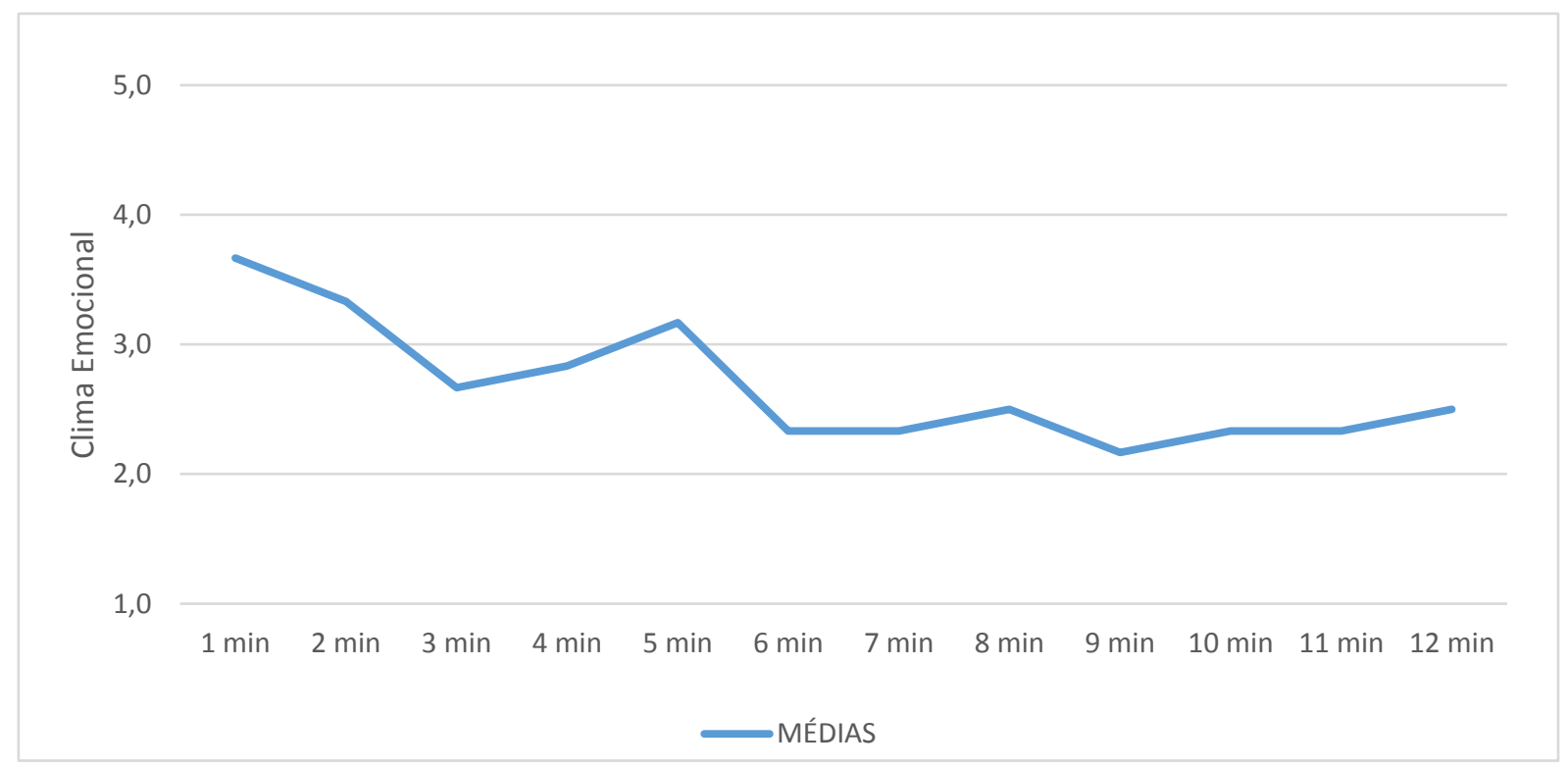

Ao analisa-lo, nos deparamos com uma situação em que perceptivelmente ocorreu um ritual de evitação. (GOFFMAN, 1982) Para melhor compreendê-lo, retomamos o momento anterior aos $5 \mathrm{~min}$, em que houve o aumento do CE seguido da queda brusca. Esse intervalo se caracteriza muito pelo fato de uma aluna ter feito uma pergunta e os estagiários se mobilizaram inicialmente na tentativa de esclarecer a dúvida da estudante, mas sem muitos argumentos explicativos. A aluna questionou se seria correto dizer "troca de energia", "troca de calor". (linha 5, APÊNDICE F)

A aluna não pareceu muito satisfeita e ficou com expressões de dúvida ou descontentamento com a explicação dada pelos estagiários. (linha 30, APÊNDICE F)

Já no instante 5 min02s (linha 24, APÊNDICE F), a estagiária Adelaide se dirige a outra aluna para interagir e parece deixar a dúvida da aluna anterior como se 
estivesse sanada, como se estivesse retirando-a do ritual de interação, e passa a explicar a equação da troca de calor que está na lousa.

Entretanto, a aluna que havia feito a pergunta sobre "troca de calor" parece inconformada [por instantes fica com cara de espanto, depois põe a mão na testa, com o cotovelo apoiado na carteira] e interrompe em voz baixa a fala da estagiária Adelaide: "Eu não estou entendendo!". Então, a estagiária pergunta: "...o que você está com dúvida aí ainda?" (Linha 36, APÊNDICE F) [A aluna sorri, disfarça, abaixa a cabeça e fala algumas coisas pouco audíveis.] E a estagiária complementa: "Pensando na vida, né!?" [A partir desse momento a aluna permanece com a cabeça baixa, mexe na calculadora/celular, e o estagiário Fernando inicia uma explanação] Mas, a dúvida da aluna, relacionada ao fato de poder ou não utilizar o termo 'troca de calor', foi deixada de lado.

Vale ressaltar que durante esta aula o pesquisador estava relativamente próximo à aluna e observou que nitidamente ela não estava conformada com a explicação que recebeu da estagiária. Ficando o pesquisador, nesse caso, com vontade de esclarecer, para a estagiária, qual era a real dúvida da aluna, que talvez não tenha conseguido se expressar adequadamente. As indagações da aluna pareciam indicar que ela não estava entendendo porque chamar 'troca de calor' se não vai calor tanto do quente para o frio quanto do frio para o quente.

Dias depois dessa aula, o pesquisador ouviu o estagiário Fernando juntamente com outros estagiários discutindo a questão de se chamar 'troca de calor', aparentemente alimentados por essa questão.

De fato, essa é uma dúvida lógica que costuma surgir algumas vezes nos alunos: se o calor vai só de um copo para outro (do mais quente para o mais frio), porque falamos em 'troca de calor'. A compreensão para essa expressão precisa ser melhor explicada quando surge essa dúvida e os estagiários parecem ter sentido algo de errado, mas limitaram-se à utilização do termo que é muito recorrente na Física para uma expressão geral que vale para vários corpos; mas costuma-se utilizar como exemplo do Princípio da Troca de Calor apenas dois corpos isolados, o que significa que se um ganhou, o outro perdeu, dando a aparente contradição lógica de que não houve nenhuma troca.

A estagiária parecia buscar salvar a fachada envergonhada (GOFFMAN, 1982) e realizou uma estratégia de aprumo para tentar salvá-la. A postura da estagiária 
parecia criar uma situação na qual a aluna não se sentia autorizada a continuar com a pergunta: levantar a cabeça e lançar a pergunta para a aluna: "O que é energia?", com um tom desafiador.

Em seguida, a estagiária passou a realizar um ritual de evitação (GOFFMAN, 1982) no qual procurou mudar de assunto, mas se viu obrigada, por alguns segundos depois, a voltar a atenção para a aluna que permanecia inconformada, pois não conseguia aceitar a explicação recebida. E para encerrar o assunto e manter a fachada, a estagiária atribuiu que a aluna não estivesse levantando dúvidas, mas apenas "pensando na vida", o que não condiz com o diálogo e a interação que estavam ocorrendo.

Nesse momento a estagiária Adelaide toca a mão várias vezes na carteira, passa o giz nas letras que já estavam escritas na lousa, virando-se de costas para os alunos, colocando o olhar para longe do olhar dos alunos. Enquanto ao se voltar para a aluna dizendo "pensando na vida, né" manteve um sorriso fixo intenso, que foi totalmente desfeito assim que olha para o lado da porta antes de olhar para a lousa.

Nesse evento, fica claro, de forma análoga ao evento analisado no episódio 1 , que esse evento de quebra da fachada desestabilizou emocionalmente a continuidade do ritual de interação, pois percebemos o CE da classe caminhou para um valor caracteristicamente negativo, o que pode ter dificultado o surgimento de um ritual de sucesso (COLLINS, 2004).

Isso nos mostra como eventos aparentemente insignificantes ou pouco percebidos, pela destreza da estagiária em despistar, de fato não são impunes para o andamento da aula. Pois, no mínimo, temos o alvoroço do embaraço (GOFFMAN, 1982), evidenciado pelo "sorriso fixo, o riso vazio nervoso, as mãos ocupadas, o olhar para o chão que esconde a expressão dos olhos", como sinais para ocultar o constrangimento. (GOFFMAN; 1982, p.102)

\footnotetext{
Esses gestos são biombos que o indivíduo usa para se esconder enquanto tenta trazer seus sentimentos de volta ao ritmo e voltar para o jogo. (GOFFMAN; 1982, p.102, tradução nossa)
}

Esse evento parece ter alterado o clima emocional da aula pois, a partir desse ponto o CE desse episódio desceu e se manteve em patamar negativo.

Depois desse evento, os estagiários seguem alternando as falas entre ambos, olhando para suas anotações e intercalando as explicações da equação da troca de calor. A estagiária Adelaide chegou a interromper uma explicação que estava 
iniciando [8min15s] e disse "a gente hoje precisa falar sobre a primeira lei da Termodinâmica", parecendo algo que estava pronto para ser entregue aos alunos. Os estagiários passam a acelerar a explicação da primeira lei da termodinâmica.

Mas, no instante $10 \mathrm{~min}$, ao lançar a pergunta sobre como obter o calor, e uma aluna afirma: "Botar fogo!" e outros alunos fazem alguns comentários [nesse momento surgem risadas na turma, mas apesar de parecer que iria subir o CE da classe, ele não sobe muito].

\subsection{Episódio 7}

O episódio 7 (Figura 9), pertencente a aula desenvolvida pela estagiária Leila e pelo estagiário Mateus, no 1ำ Termo, tinha como conteúdo abordado as Leis de Newton. O trecho da aula foi conduzido apenas pela estagiária Leila, apesar do estagiário Mateus estar à frente da turma, movendo-se de um lado para outro, juntamente com a estagiária.

Durante o episódio analisado, o CE médio oscilou bastante, sem se manter em nenhum ponto mais específico, mas existe uma perceptível tendência do aumento do valor do $\mathrm{CE}$, parecendo caracterizar um evento no intervalo de $6 \mathrm{~min}$ a $8 \mathrm{~min}$

A aula foi conduzida com uma apresentação de textos e imagens em uma tela de TV. A estagiária Leila usou o recurso de uma narrativa para contar uma historinha das Leis de Newton, utilizando inclusive a anedota da maçã que teria caído na cabeça de Newton. Posteriormente, a estagiária questiona os alunos sobre se a imagem que retrata Newton seria de fato uma representação dele. Valendo-se desses recursos, a estagiária aparentemente criou algum envolvimento dos alunos na história e nos problemas que vai apresentando, de forma que os alunos apresentam sugestões sobre o que irá acontecer. 
Figura 9 - Gráfico das médias do clima emocional do Episódio 7

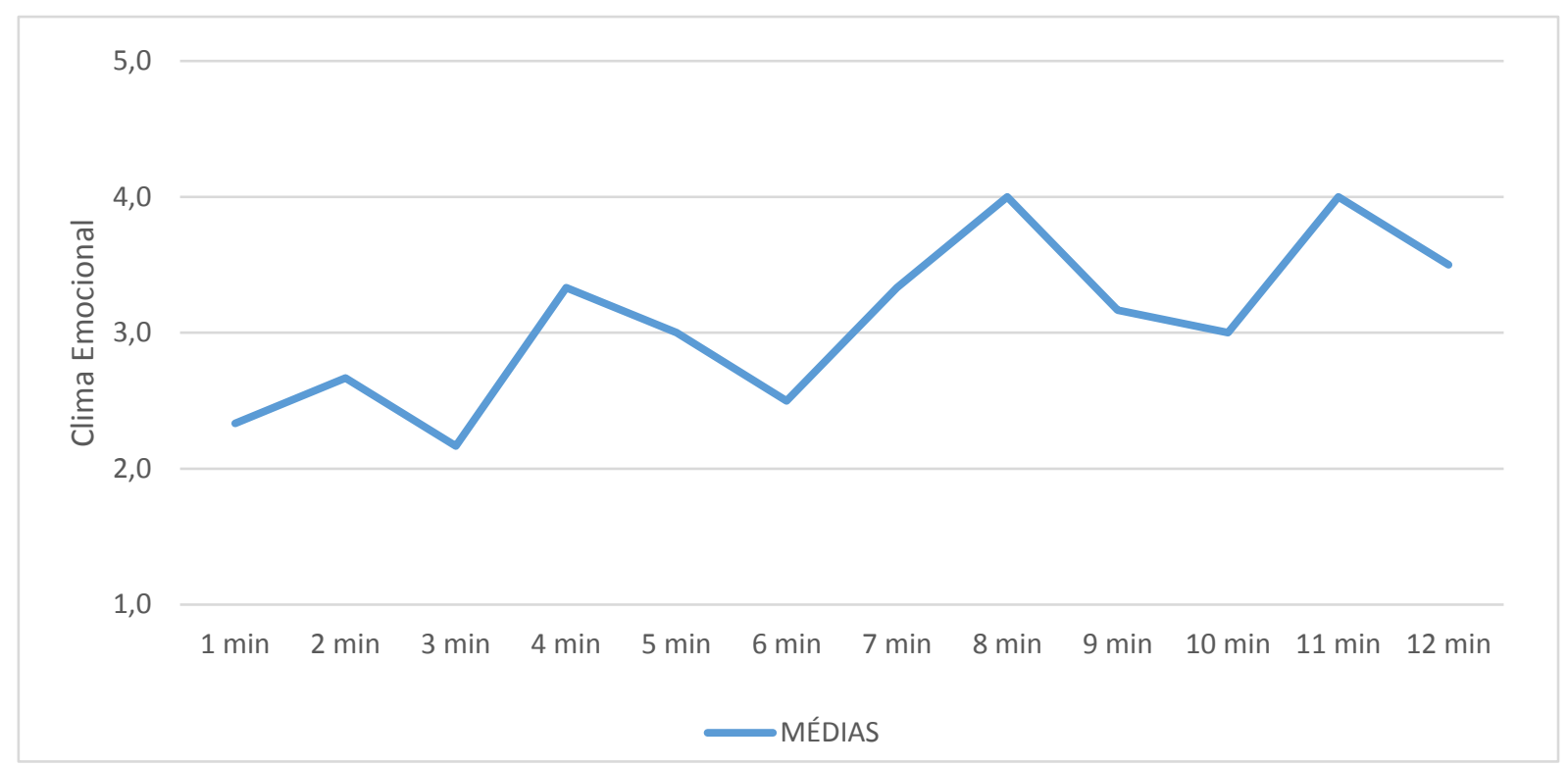

Entre o instante $3 \mathrm{~min}$ e $4 \mathrm{~min}$ ocorreu a maior variação do CE em um intervalo de $1 \mathrm{~min}$. Mas, apesar de alguns alunos terem ensaiado risadas baixas e leves (em menor intensidade que outros momentos) quando a professora contou a anedota da "maçã que caiu na cabeça no senhor Newton", ao assistir e analisar o trecho não nos pareceu haver ali um evento.

Entre os instantes 6 min e 8 min ocorre um contínuo aumento do CE, chegando a 4,0. Durante esse intervalo, o nível de risadas vai aumentando bastante, os alunos opinaram sobre as perguntas lançadas pela estagiária e o clima ficou bem eufórico quando alguns afirmaram que os dois corpos que a estagiária apresentou no vídeo estavam parados, justificando que "se está parado, está parado", o que resultou em risadas mais intensas.

Nesse intervalo está ocorrendo uma forte indagação por parte dos alunos, uma relutância em aceitar a explicação de que "algo pode estar parado e andando ao mesmo tempo", mostrando que os estudantes estão presos a uma lógica linguística apenas.

Dessa forma, esse intervalo parece melhor caracterizar um evento e tem uma semelhança com o evento no episódio 1 , no qual os alunos não estavam aceitando a explicação do estagiário, gerando euforia na classe. Este episódio poderia estar relacionado com uma iminente quebra da fachada, mas que nesse caso não chegou a ocorrer pois a estagiária não apresentou constrangimento ou perda da fachada. 
Já dos $8 \mathrm{~min}$ até os $10 \mathrm{~min}$, a estagiária passa a fazer a explicação e afirmou que o questionamento era importante e que as duas respostas ('o carro está parado' e 'o carro está se movendo') estão certas pois depende do referencial para dizermos se o corpo está parado ou em movimento. No entanto, os alunos pareceram não entender porque "um corpo parado está em movimento". Por fim a estagiária afirma: "Então, eu vou dizer para vocês que todo mundo está certo, ninguém está errado. Todo mundo tá certo. Isso vai depender do referencial de vocês." (9min25s). 


\section{CONSIDERAÇÕES FINAIS}

Algumas pesquisas (LEITE; TASSONI, 2002; MAHONEY; ALMEIDA, 2005; SANTOS, 2007; RICARDO et al, 2012) já mostraram que a sala de aula é um espaço envolto de emoções e que estas podem afetar a aprendizagem e o processo didático.

Nosso trabalho permitiu ir um pouco além, mostrando que o processo de ensinar física, durante abordagem de um conceito científico, não estão em jogo apenas processos cognitivos, mas uma interação social cuja linguagem das emoções revelam os rituais de interação (GOFFMAN, 1982) que estão em jogo, consciente ou inconscientemente pelo professor; podendo até mesmo subverter aspectos conceituais físicos para poder salva a sua fachada (GOFFMAN, 1982), seja por processos de aprumo (Episódio 1, por exemplo) ou de evitação (Episódio 6, por exemplo).

Dessa forma, nosso trabalho também evidencia a complexidade do processo de ensino e aprendizagem no que diz respeito ao papel das emoções nesse processo, visto que embora nem os alunos aparentam ter percebido o que aconteceu, nem os leigos que assistiram aos vídeos dos episódios, o clima emocional se mostra alterado nos momentos em que o professor está realizando o salvamento da fachada, o que pode significar que os sujeitos percebam pela linguagem das emoções que alguma coisa está em risco naqueles momentos.

Assim, fica evidente a importância de o professor ter momentos de se colocar de fora desse processo (filmando e assistindo suas abordagens em sala de aula, por exemplo) para poder realizar processos reflexivos (SCHÖN, 1992) que ajudem a mudar sua prática.

Nosso trabalho mostrou também que a indicação do CE por pessoas que assistem a uma interação social e não participam diretamente dela (Tobin e Ritchie; 2012, Tobin et al.;2016) se mostra como um potencial heurístico para a identificação de eventos emocionais na sala de aula, deixando de ser um fator incômodo solicitar aos alunos que parem por alguns segundos para pontuar sobre o clima emocional. Isso ficou claro em nossa pesquisa ao percebermos que os gráficos de CE possuem uma grande variação em momentos em que situações com rituais de interação e emoções estão em jogo e que ao perguntarmos para as pessoas que assistiram aos 
vídeos e pontuaram sobre o CE se haviam percebido algo de diferente afirmaram que não conseguiram entender nada do que estava acontecendo ou sendo dito.

Isso nos mostra que tanto as emoções estão fortemente presentes durante uma abordagem de conceitos de física em sala de aula, quanto processos de interação social estão em jogo nesse momento, por mais que pareça à primeira vista ser apenas uma interação cognitiva, de troca de conhecimentos.

Emoções estão sendo trocadas, rituais de interação estão em jogo a todo momento. Esses rituais não estão apenas a serviço do conhecimento, das trocas cognitivas, mas antes, satisfazem questões sociais mais presentes no ensino da Física do que possamos admitir a priori.

Os momentos de CE próximo de neutro (3) revelaram momentos em que as pessoas estão expressando poucas emoções (por estarem concentradas, pensando em alguma questão teórica, lógica ou que exija muita concentração) mas também em casos de apatia ou pouco interesse.

Se, por um lado, CE alto pode estar relacionado com rituais de sucesso e CE muito baixo, a situações monótonas, de pouco engajamento, o episódio 6 nos mostra que o ritual de evitação pode ter afetado o CE da classe para além do momento.

Prestar atenção às variações bruscas de CE pode revelar algo que esteja acontecendo na interação social e nas emoções dos envolvidos.

De fato, os dois episódios (1 e 6) que identificamos as maiores variações do CE foram caracterizados por aspectos muito marcantes da aula. Outros eventos, tiveram menos impacto, mas também revelam aspectos já identificados em pesquisas anteriores.

Algumas situações em que os estagiários possam ter realizado rituais de salvamento da fachada podem não ter sido detectados com tanta nitidez como aqueles dois, por ter ocorrido muito rapidamente, ficando restrito a poucos segundos e não aparecendo nas medidas do CE, e por isso ausentes da nossa análise. Mas, as alterações significativas do CE mostraram a capacidade de revelar aspectos importantes do processo educacional enquanto encontro face a face.

Desta forma, o processo de ensino e aprendizagem é uma interação social que envolve muito mais aspectos do que apenas processos cognitivos e troca de conhecimentos. Envolvem também aspectos emocionais que caracterizam qualquer 
interação social. Ignorar esse aspecto pode aleijar o processo educacional como um todo e o próprio processo cognitivo na troca de conhecimentos.

Mais do que isso, comumente temos a falsa impressão de que emoção e cognição sejam processos que ocorram separada e distintamente, ao passo que as emoções, enquanto uma linguagem primitiva do pensamento humano (TURNER, 2007), estão presentes no processo de interação social, como vimos em nossa pesquisa, chegando, como no caso do episódio 1 , poder subverter o conhecimento físico e mesmo lógico.

Nosso trabalho mostra, como apontado por Goffman (1982), que a busca de uma fachada é um ato intrínseco à natureza da sociabilidade humana nos encontros face a face e que pode levar, em alguns momentos, a rituais de salvamento da fachada. Assim, é importante que o professor tenha consciência de que esses aspectos estão presentes mesmo durante abordagem conceitual.

O professor não começa a se formar enquanto está colocando em prática suas metodologias de ensino ou apresentando conceitos científicos, mas antes, dentro de uma estrutura escolar e social subjacente a todo o processo educacional, que já traz intrinsicamente ideias como o professor sendo o detentor do conhecimento, por mais que nas metodologias educacionais mais atuais se defenda que o professor seja um mediador do conhecimento, que os alunos sejam protagonistas do seu aprendizado.

Por isso, para que ocorram mudanças no processo educacional, na qual os professores rompam com a estrutura existente na qual é visto como o detentor do conhecimento, é preciso que o professor tome consciência dos rituais que realiza, para poder buscar formas diferentes de se colocar na estrutura social da sala de aula, que não reproduzam a estrutura tradicional do processo educacional.

Dessa forma, chamamos atenção para a necessidade de os professores poderem refletir sobre sua prática, de poderem exercer um olhar de fora para ela (por exemplo, gravando e assistindo suas aulas), trocarem experiências com seus pares ou formadores sem que sejam julgados moralmente ou coercitivamente, como formas de estimular processos metacognitivos.

$O$ ato de ensinar envolve diversos aspectos, não apenas cognitivo e didático, nem a cognição e a emoção estão separadas em nossos atos humanos. Além disso, a estrutura tradicional se manifesta quando o professor, mesmo com as melhores das intenções, realiza o processo educacional. 
Assim, contrapondo a ideias que contestam a importância do conteúdo da formação do professor reflexivo, reiteramos a importância não apenas de o professor refletir sobre sua prática, como utilizar, por exemplo, as características das interações face a face, inerentes a todo encontro social, para compreender que fachadas ele anda criando em sua prática educacional, para conscientizá-lo da necessidade de buscar a construção de fachadas com características mais dialógicas, inclusivas, nas quais o aluno seja parte do processo de pensar sobre o conhecimento e que este não esteja centrado no professor.

Finalmente, com relação à nossa pergunta inicial, percebemos que muitas vezes o professor de fato se vê (consciente ou inconscientemente) dividido entre seguir o que pretendia abordar do ponto de vista didático ou conceitual ou, enquanto participante de um encontro social face a face, permanecer no jogo, salvando a sua fachada. Como apontado por Goffman (1982), essa necessidade de salvar a fachada é inerente à natureza humana e ao jogo da interação face a face.

Mas, se o professor compreender melhor esse processo inerente à sala de aula, realizando processos reflexivos (SCHÖN, 1992) e metacognitivos, acreditamos que possa desenvolver habilidades em realizar mais processos corretivos (GOFFMAN, 1982), como encarar o problema e buscar junto com os alunos a explicação para o mesmo.

Entendemos que para formarmos professores que rompam com a cultura tradicional da sala de aula, que vê no professor o detentor do conhecimento, precisamos permitir que ele repense sua prática, com formas concretas sobre suas ações.

Nosso trabalho pretende assim ajudar na percepção da importância de olhar para a complexidade das ações do professor, fomentando esse olhar com o referencial microssociológico e sua relação com as emoções dos participantes do encontro, para que este olhar ajude o professor a fazer mais escolhas por processos corretivos durante suas abordagens educacionais. 


\section{REFERÊNCIAS}

ALVESSON, Mats; SKÖLDBERG, Kaj. Reflexive methodology: New vistas for qualitative research. Sage, 2009.

ASTOLFI, Jean-Pierre. Trois paradigmes pour les recherches en didactique. Revue française de pédagogie, p. 5-18, 1993.

ATKINSON, Anthony P., et al. Emotion perception from dynamic and static body expressions in point-light and full-light displays. Perception 33.6 (2004): 717-746.

AUSUBEL, David. The Use of Ideational Organizers in Science Teaching. Occasional Paper 3. ERIC Information Analysis Center for Science Education, Columbus, Ohio, 1970.

BACHELARD, Gaston. A formação do espírito científico. Tradução: Estela dos Santos Abreu. Contraponto Editora. 3aㅡ ed. Rio de Janeiro, 2002.

BANDURA, A. Self-Efficacy: Toward a Unifying Theory of Behavioral Change. Psychological Review, 87 (2); pp. 191-215.

BELLOCCHI, Alberto et al. Exploring emotional climate in preservice science teacher education. Cultural Studies of Science Education, v. 8, n. 3, p. 529-552, 2013.

BELLOCCHI, Alberto; MILLS, Kathy A.; RITCHIE, Stephen M. Emotional experiences of preservice science teachers in online learning: the formation, disruption and maintenance of social bonds. Cultural Studies of Science Education, p. 1-24, 2015.

BONDERUP DOHN, Niels. Situational interest of high school students who visit an aquarium. Science Education, v. 95, n. 2, p. 337-357, 2011.

BORRACHERO, Ana Belén et al. Relationship between self-efficacy beliefs and emotions of future teachers of Physics in secondary education. In: Asia-Pacific Forum on Science Learning and Teaching. Hong Kong Institute of Education. 10 Lo Ping Road, Tai Po, New Territories, Hong Kong, 2013. p. n2.

BORRACHERO, Ana Belén et al. Emotions in prospective secondary teachers when teaching science content, distinguishing by gender. Research in Science \& Technological Education, v. 32, n. 2, p. 182-215, 2014.

BRASIL. Ministério da Educação e Cultura. Secretaria de Educação Fundamental. Parâmetros Curriculares Nacionais: Ciências Naturais/Secretaria de Educação Fundamental. Brasília: MEC/SEF, 1998.

BRASIL. Ministério da Educação e Cultura. Conselho Nacional de Educação. Base Nacional Comum Curricular. Brasília:MEC/SEB, 2017.

BRIGIDO, María et al. Prospective primary teachers' self-efficacy and emotions in science teaching. European Journal of Teacher Education, v. 36, n. 2, p. 200-217, 2013. 
BZUNECK, José Aloyseo. As crenças de autoeficácia dos professores. In.: FERMINO. F. Sisto; OLIVEIRA, Gislene de C.; FINI, Lucila D. T. (Org.) (2000). Leituras de Psicologia para Formação de Professores. Petrópolis, Editora Vozes, pp.115-134.

CARVALHO, A.M.P. de; GIL PÉREZ, Daniel. As Pesquisas em Ensino Influenciando a Formação de Professores. Revista Brasileira de Ensino de Física. Vol. 14, oㅡ 4, 1992.

CARVALHO, A.M.P.; VANNUCHI, A. O currículo de Física: inovações e tendências nos anos noventa. Revista Investigações em Ensino de Ciências, v.1, n.․1, pp.319, Abril 1996.

CARVALHO, Anna Maria Pessoa. Metodología de investigación en enseñanza de física: Una propuesta para estudiar los procesos de enseñanza y aprendizaje. Revista de Enseñanza de la Física, v. 18, n. 1, p. 29-37, 2005.

CHOMSKY, Noam. Novos Horizontes no estudo da linguagem e da mente. Trad. Marco Antônio Sant'Anna. Editora UNESP. São Paulo, 2005.

COLLINS, Randall. On de Microfoundations of Macrosociology. American Journal of Sociology. Vol.86, N o.5 (Mar., 1981), pp. 984-1014. The University Chicago Press, 1981.

COLLINS, Randall. Emotional energy as the common denominator of rational action. Rationality and society, v. 5, n. 2, p. 203-230, 1993.

COLLINS, Randall. The Sociology of Philosophies. A Global Theory of Intellectual Change. Harvard University Press, 2002.

COLLINS, Randall. Interaction Ritual Chains. Princeton University Press, Princeton and Oxford, 2004.

COLLINS, Randall. Quatro Tradições Sociológicas. Trad. Raquel Weiss. Petrópolis, RJ: Vozes, 2009.

DAMÁSIO, António. $O$ erro de Descartes: Emoção, razão e o cérebro humano. Tradução: Dora Vicente, Georgina Segurado. 3a. ed. Companhia das Letras. São Paulo, 2012.

DANTAS, Heloysa. A afetividade e a Construção do Sujeito na Psicogenética de Wallon. In.: PIAGET, VYGOTSKY, WALLON - Teorias Psicogenéticas em discussão / Yves de La Taille, Marta Kohl de Oliveira, Heloysa Dantas. São Paulo: Summus, 1992.

DARWIN, Charles. A expressão das emoções no homem e nos animais. Tradução: Leon de Souza Lobo Garcia. (2ª reimpressão) Companhia da Letras, 2009/1872. 
DELIZOICOV, D. Pesquisa em ensino de ciências como ciências humanas aplicadas. Caderno Brasileiro de Ensino de Física, v. 21, n. 2, p. 145-175, 2004.

DREON, Oliver; MCDONALD, Scott. Being in the hot spot: a phenomenological study of two beginning teachers' experiences enacting inquiry science pedagogy. Teachers and Teaching, v. 18, n. 3, p. 297-313, 2012.

EKMAN, Paul. Are There Basic Emotions? Psychological Review. Vol. 99. No. 3. pp.550-553, 1992.

EKMAN, Paul. Emotions revealed: Recognizing faces and feelings to improve communication and emotional life. Macmillan, 2007.

ENGELMANN, Arno. In: Os estados subjetivos: Uma tentativa de classificação de seus relatos verbais. 1978. Apud: LEITE, Sergio Antônio da Silva; TASSONI, Elvira Cristina Martins. A afetividade em sala de aula: as condições de ensino e a mediação do professor. Psicologia e formação docente: desafios e conversas. São Paulo: Casa do Psicólogo, p. 113-141, 2002.

FERNANDES, Reinaldo; OJEDA, Renato Garcia; LUCATELLI, Marcos Vinicius. Ensaios para avaliacao de funcionalidade de oxímetros de pulso. In: Memorias II Congreso Latinoamericano de Ingeniería Biomédica, Habana. 2001.

FODOR, Jerry A. The Mind-Body Problem. Scientific American. vol. 244. nำ, pp.114123, January, 1981.

FRANKE, Gaitano; BOGNER, Franz X. How does integrating alternative conceptions into lessons influence pupils' situational emotions and learning achievement? Journal of Biological Education, v. 47, n. 1, p. 1-11, 2013.

GARDNER, Howard. The mind's new science. A history of the Cognitive Revolution. Basic Books, Inc., Publishers, New York, 1985.

GOFFMAN, Erving. Interaction Ritual: essays on face-to-face behavior. Pantheon Books, New York, 1982/1967.

GOFFMAN, Erving. Os quadros da experiência social. Uma perspectiva de análise. Trad. Gentil A. Titton. Petrópolis, RJ: Vozes, 2012.

GOWIN, D.B.; Alvarez, M. The art of educating with V diagrams. Cambridge University Press, New York: 2005.

KING, Donna et al. Emotionally intense science activities. International Journal of Science Education, v. 37, n. 12, p. 1886-1914, 2015.

KRASILCHIK, Myriam. Reformas e Realidade - O caso do ensino das ciências. São Paulo em Perspectiva. Vol.14. n. $\stackrel{0}{1}$. Jan/Mar 2000.

LA TAILLE, Yves de. O lugar da interação social na concepção de Jean Piaget. In.: PIAGET, VYGOTSKY, WALLON - Teorias Psicogenéticas em discussão / Yves de La Taille, Marta Kohl de Oliveira, Heloysa Dantas. São Paulo: Summus, 1992. 
LEITE, Sergio A. da Silva; TASSONI, Elvira Cristina Martins. A afetividade em sala de aula: as condições de ensino e a mediação do professor. Psicologia e formação docente: desafios e conversas. São Paulo: Casa do Psicólogo, p. 113-141, 2002.

LÓPEZ, Veronica et al. La sala de classes sí importa: incidencia del clima de aula sobre la percepción de intimidación y vietimización entre escolares. Universitas Psychologica, vol. 11, núm.1, enero-marzo, pp. 91-101 Pontificia Universidad Javeriana Bogotá, Colombia, 2012.

LÜDKE, Menga e ANDRÉ, Marli E. D. A. (1986) Pesquisa em Educação: Abordagens Qualitativas. São Paulo: Editora Pedagógica e Universitária, 1986.

MAHONEY, Abigail Alvarenga; ALMEIDA, Laurinda Ramalho de. Afetividade e processo ensino-aprendizagem: contribuições de Henri Wallon. Psicologia da educação, n. 20, p. 11-30, 2005.

MARHUENDA, Fernando; NAVAS, Almudena; PINAZO, Sacramento. Conflicto, disciplina y clima de aula: La garantía social como respuesta al control social sobre los jóvenes. Identidades y formación para el trabajo em los márgenes del sistema educativo: escenarios contradictorios em la garantía social, Montevideo, Cinterfor/OIT, pp.255-299, 2004.

MARTINS, Carlos Benedito de Campos. Nota sobre o sentimento de embaraço em Erving Goffman. Revista Brasileira de Ciências Sociais. Vol.23, n.ำ 68, Outubro, 2008.

MARTINS, Magda Alexandra da Silva. Clima de Sala de Aula: Percepções dos alunos do $3^{\circ}$ ciclo em relação às disciplinas de Português e Educação Física. Instituto Universitário de Ciências Psicológicas, Sociais e da Vida. ISPA - Instituto Superior de Psicologia Aplicada (tese), Lisboa, 2014.

MATSUMOTO, David; YOO, S. Hee; LEROUX, Jeffery A. Emotion and intercultural communication. Kwansei Gakuin University Journal, v. 99, p. 15-38, 2005.

MELVILLE, Wayne; BARTLEY, Anthony. Constituting identities that challenge the contemporary discourse: Power, discourse, experience, and emotion. Science Education, v. 97, n. 2, p. 171-190, 2013.

MONTEIRO, Isabel Cristina de Castro; GASPAR, Alberto. Um estudo sobre as emoções no contexto das interações sociais em sala de aula. Investigações em Ensino de Ciências. V.12(1), pp.71-84, 2007.

NOVAK, J.D. Clarify with concept maps. The Science Teacher, 58(7):45-49, 1991.

OJALA, Maria. Regulating Worry, Promoting Hope: How Do Children, Adolescents, and Young Adults Cope with Climate Change? International Journal of Environmental and Science Education, v. 7, n. 4, p. 537-561, 2012. 
OLITSKY, Stacy. We teach as we are taught: exploring the potential for emotional climate to enhance elementary science preservice teacher education. Cultural Studies of Science Education, v. 8, n. 3, p. 561-570, 2013.

OSTERMANN, F.; MOREIRA, M. A. Atualização do currículo de Física na escola de nível médio: um estudo desta problemática na perspectiva de uma experiência em sala de aula e da formação inicial de professores. Caderno Catarinense de Ensino de Física, Florianópolis, v.18, n.르, pp.135-151, Agosto 2001.

PEDUZZI, L. O. Q. et al. As Concepções Espontâneas, a Resolução de Problemas e a História da Ciência numa sequência de conteúdos em Mecânica: o referencial teórico e a receptividade de estudantes universitários à abordagem histórica da relação força e movimento. Revista Brasileira de Ensino de Física, v.14, n.느, pp.239-246, São Paulo, Dezembro, 1992.

PESSOA, Fernando; AYALA, Walmir. Antologia poética - Fernando Pessoa. Org. Walmir Ayala. Nova Fronteira, Rio de Janeiro, 2017.

PESSOA JR, Osvaldo. A física quântica seria necessária para explicar a consciência? Questões metodológicas em ciências cognitivas, p. 184-9, 1994. (nova numeração: Série Ciência e Tecnologia - 37)

PIAGET, Jean. Epistemologia Genética. Tradução: Álvaro Cabral, 3a․ ed. Martins Fontes: São Paulo, 2007.

RANDLER, Christoph et al. Influence of a Dissection Video Clip on Anxiety, Affect, and Self-Efficacy in Educational Dissection: A Treatment Study. CBE-Life Sciences Education, v. 15, n. 1, p. ar1, 2016.

REZENDE, Flavia; OSTERMANN, Fernando. A prática do professor e a pesquisa em ensino de Física: novos elementos para repensar essa relação. Caderno Brasileiro de Ensino de Física, v.22, n.3, p.316-337, 2005.

RICARDO, Ana Filipa et al. Motivação para aprendizagem matemática e sua relação com percepção de clima de sala de aula. Actas do $12^{\circ}$ Coloquio de Psicologia e Educação. pp.153-1168, Lisboa, 2012.

RINCHEN, Sonam; RITCHIE, Stephen M.; BELLOCCHI, Alberto. Emotional climate of a pre-service science teacher education class in Bhutan. Cultural Studies of Science Education, p. 1-26, 2016.

RITCHIE, Stephen M. et al. Reproducing successful rituals in bad times: Exploring emotional interactions of a new science teacher. Science Education, v. 95, n. 4, p. 745-765, 2011.

RITCHIE, Stephen M. et al. Emotional arousal of beginning physics teachers during extended experimental investigations. Journal of Research in Science Teaching, v. 50, n. 2, p. 137-161, 2013. 
SANTOS, Flávia Maria Teixeira dos. As emoções nas interações e a aprendizagem significativa. Ensaio Pesquisa em Educação em Ciências (Belo Horizonte), v. 9, n. 2, p. 173-187, 2007.

SCHERER, Klaus R. Vocal communication of emotion: A review of research paradigms. Speech communication, v. 40, n. 1-2, p. 227-256, 2003.

SCHÖN, Donald. Formar professores como profissionais reflexivos. Os professores e sua formação. Lisboa: Dom Quixote, v. 2, p. 77-91, 1992.

SEWELL JR, W. H. Logics of history: social theory and social transformation. Chicago: The University of Chicago Press, 2005.

SMITH, Tiffany Watt. The Book of Human Emotions: An Encyclopedia of Feeling from Anger to Wanderlust. Profile Books, 2015.

TOBIN, Kenneth; RITCHIE, Stephen M. Multi-Method, Multi-Theoretical, Multi-Level Research in the Learning Sciences. The Asia-Pacific Education Researcher, n. 21, v. 1, p. 117-129, 2012.

TOBIN, Kenneth; RITCHIE, Stephen M.; OAKLEY, Jennifer L.; MERGARD, Victoria; HUDSON, Peter. Relationship between emotional climate and the fluency of classroom interactions. Learning Environment Research. 16:71-89, 2013.

TOBIN, Kenneth et al. Expression of emotions and physiological changes during teaching. Cultural Studies of Science Education, v. 11, n. 3, p. 669-692, 2016.

TURNER, Jonathan $\mathrm{H}$. Origens das Emoções Humanas: Um inquérito sociológico acerca da evolução da afectividade. Instituto Piaget, Lisboa, 2003.

TURNER, Jonathan H. Human emotions: A sociological theory. Taylor \& Francis, 2007.

VERISSIMO, Danilo Saretta e FURLAN, Reinaldo. As críticas de Henri Bergson e de Maurice Merleau-Ponty aos enforques materialistas do problema corpo-mente. Psicologia USP, abril/junho, 2009, pp.193-208.

VIENNOT, Laurence. Teaching rituals and students' intellectual satisfaction. This paper is based on a keynote address given at the ICPE International Conference on Physics Education: World View on Physics Education in 2005, University of New Delhi. Physics Education, v. 41, n. 5, p. 400, 2006.

VILLANI, A. Considerações sobre a pesquisa em Ensino de Ciências: II. Seu significado, seus problemas e suas perspectivas. Revista de Ensino de Física, São Paulo, v.4, pp.125-150, Dezembro, 1982.

VYGOTSKY, L. S. A formação social da mente. São Paulo, Martins Fontes, 1984. 
WALLON, Henri. As Origens do Caráter na Criança. Tradução: Heloysa Dantas de Souza Pinto. São Paulo: Nova Alexandria, 1995.

WALLON, Henri. Les étapes de la sociabilité chez l'enfant. In.: Encance, tome 12, n`34, 1959. Psychologie et Éducation de l'Enfance. pp. 309-323; doi: 10.3406/enfan.1959.1446. Disponível em:

http://www.persee.fr/doc/enfan 0013-7545 1959 num 1231446 (Acesso em: 27 fev. 2018) 


\section{APÊNDICE A: TRANSCRIÇÃO DO EPISÓDIO $1^{23}$}

\begin{tabular}{|c|c|c|c|c|}
\hline \multicolumn{5}{|c|}{ Episódio 1} \\
\hline Linha & Participante & Tempo & Processos verbais & Processos não verbais \\
\hline 1 & $\begin{array}{l}\text { Estagiário } \\
\text { Adriano }\end{array}$ & $18 \min 51 \mathrm{~s}$ & $\begin{array}{l}\text { O que... o que } \\
\text { ele tá falando... }\end{array}$ & $\begin{array}{l}\text { [gesticulando com a mão direita } \\
\text { à meia altura] }\end{array}$ \\
\hline 2 & $\begin{array}{l}\text { Estagiário } \\
\text { Adriano }\end{array}$ & 18min52s & $\begin{array}{l}\text {...deixa eu dar um } \\
\text { exemplo prático. }\end{array}$ & $\begin{array}{l}\text { Leva a mão direita fechando - } \\
\text { posição de exatidão, à frente; } \\
\text { em seguida toca o polegar com } \\
\text { o indicador (iniciando } \\
\text { "contagem") }\end{array}$ \\
\hline 3 & $\begin{array}{l}\text { Estagiário } \\
\text { Adriano }\end{array}$ & $18 \min 54 s$ & $\begin{array}{l}\text {...aconteceu na minha } \\
\text { casa isso. }\end{array}$ & $\begin{array}{l}\text { com a mão esquerda aberta } \\
\text { entrando na direita semiaberta. }\end{array}$ \\
\hline 4 & $\begin{array}{l}\text { Estagiário } \\
\text { Adriano }\end{array}$ & $18 \min 56 s$ & $\begin{array}{l}\text { Fiz toda a instalação } \\
\text { elétrica, dimensionei } \\
\text { todos os setores, } \\
\text { como os amigos } \\
\text { falaram... }\end{array}$ & $\begin{array}{l}\text { nesse momento, sorri, aponta a } \\
\text { mão direita com o indicador } \\
\text { para alguns alunos }\end{array}$ \\
\hline 5 & $\begin{array}{l}\text { Estagiário } \\
\text { Adriano }\end{array}$ & $19 \mathrm{~min} 01 \mathrm{~s}$ & $\begin{array}{l}\text { Coloquei um disjuntor } \\
\text { só pro micro-ondas... } \\
\text { um disjuntor... pro } \\
\text { chuveiro.. }\end{array}$ & $\begin{array}{l}\text { Usou os dedos para contar, } \\
\text { como se estivesse enumerando } \\
\text { o que fez. }\end{array}$ \\
\hline 6 & $\begin{array}{l}\text { Estagiário } \\
\text { Fabiano }\end{array}$ & $\begin{array}{l}19 \min 06 s \\
\mathrm{a} \\
19 \min 08 \mathrm{~s}\end{array}$ & $\begin{array}{l}\text { Individualizou os } \\
\text { equipamentos da } \\
\text { casa. }\end{array}$ & $\begin{array}{l}\text { Passou a mão direita à meia } \\
\text { altura fazendo meio círculo em } \\
\text { volta de si }\end{array}$ \\
\hline 7 & $\begin{array}{l}\text { Estagiário } \\
\text { Adriano }\end{array}$ & $19 \min 08 \mathrm{~s}$ & Exatamente! & $\begin{array}{l}\text { Entrelaçou os dedos e em } \\
\text { seguida mexeu na aliança no } \\
\text { dedo esquerdo. } \\
\text { [enquanto entrelaçava } \\
\text { dedos, Aluno } 1 \text { fala (pouco } \\
\text { audível): "...isso é bom... na } \\
\text { hora da instalação" }\end{array}$ \\
\hline 8 & $\begin{array}{l}\text { Estagiário } \\
\text { Adriano }\end{array}$ & $\begin{array}{l}19 \min 09 \mathrm{~s} \\
\mathrm{a} \\
19 \min 11 \mathrm{~s}\end{array}$ & $\begin{array}{l}\text { Isso é importante na } \\
\text { hora de fazer uma } \\
\text { instalação. }\end{array}$ & \\
\hline 9 & Aluno 1 & $\begin{array}{l}19 \min 10 \mathrm{~s} \\
\mathrm{a} \\
19 \min 11 \mathrm{~s}\end{array}$ & $\begin{array}{l}\text {...isso é bom... na } \\
\text { hora da instalação. }\end{array}$ & $\begin{array}{l}\text { Aluno } 1 \text { está sentado com as } \\
\text { mãos para trás e pernas caídas } \\
\text { para frente. }\end{array}$ \\
\hline 10 & $\begin{array}{l}\text { Estagiário } \\
\text { Adriano }\end{array}$ & $\begin{array}{l}19 \min 12 \mathrm{a} \\
19 \min 19 \mathrm{~s}\end{array}$ & $\begin{array}{l}\text { O que aconteceu? } \\
\text { Tava um dia muito } \\
\text { quente. Eu fui trocar lá } \\
\text { a minha resistência } \\
\text { que tinha queimado... }\end{array}$ & $\begin{array}{l}\text { Mexe um pouco nos dedos e } \\
\text { mexe bastante na aliança. } \\
\text { Em seguida gesticula com } \\
\text { dedos (levando mão direita ao } \\
\text { alto) como estivesse mexendo } \\
\text { em um botão. }\end{array}$ \\
\hline 11 & $\begin{array}{l}\text { Estagiário } \\
\text { Adriano }\end{array}$ & $19 \min 19 s$ & Aí o que que eu fiz? & Mexe na aliança \\
\hline
\end{tabular}

23 Incluímos os processos não verbais em todas as transcrições por entendermos que eles ajudam na compreensão do que estava acontecendo em termos das emoções e dos rituais de interação durante o episódio. Por isso, em geral, os processos não verbais foram determinantes no estabelecimento das linhas utilizadas para as transcrições. 


\begin{tabular}{|c|c|c|c|c|}
\hline 12 & $\begin{array}{l}\text { Estagiário } \\
\text { Adriano }\end{array}$ & $\begin{array}{l}19 \min 20 \mathrm{~s} \\
\mathrm{a} \\
19 \min 28 \mathrm{~s}\end{array}$ & $\begin{array}{l}\text { Eu deixei no, na... na } \\
\text { temperatura da água } \\
\text { mais quente e ... abri o } \\
\text { registro. Só que eu } \\
\text { abri só um pouquinho. } \\
\text { O que que } \\
\text { aconteceu? }\end{array}$ & $\begin{array}{l}\text { Gira a mão direita à meia altura } \\
\text { com os dedos abertos (como } \\
\text { segurando e girando um } \\
\text { registro de água) }\end{array}$ \\
\hline 13 & $\begin{array}{l}\text { Estagiário } \\
\text { Adriano }\end{array}$ & $\begin{array}{l}19 \min 29 \mathrm{~s} \\
\mathrm{a} \\
19 \min 40 \mathrm{~s}\end{array}$ & $\begin{array}{l}\text { Aí eu vi como estava } \\
\text { a temperatura e tal e } \\
\text { desliguei. } \\
\text { De repente eu } \\
\text { voltei pro meu quarto, } \\
\text { onde estava o quadro } \\
\text { elétrico, senti um } \\
\text { cheiro de queimado. } \\
\text {... Fui abrir o quadro, } \\
\text { quando eu vi, o fio } \\
\text { estava meio que } \\
\text { derretendo... }\end{array}$ & \\
\hline 14 & $\begin{array}{l}\text { Estagiário } \\
\text { Adriano }\end{array}$ & 19min41s & $\begin{array}{l}\text { falha (pulo } r \\
\text { filmagem na câmera } \\
\text { de frente para a } \\
\text { classe) } \\
\text { No vídeo de frente } \\
\text { para os estagiários, } \\
\text { corresponde a } \\
\text { seguinte } \\
\text { (duração: 12s) } \\
\text { achala: que vocês } \\
\text { acham que } \\
\text { aconteceu? Tava um } \\
\text { dia bem quente! Eu } \\
\text { instalei um res... uma } \\
\text { resistência nova, abri } \\
\text { só um pouquinho o } \\
\text { registro, saiu uma } \\
\text { água pelando, e o meu } \\
\text { fio do outro lado } \\
\text { estava derretendo. }\end{array}$ & $\begin{array}{l}\text { Gesticulou com as duas mãos } \\
\text { abertas na vertical e gira a } \\
\text { cabeça levemente para o lado. } \\
\text { (esses 12s não foram vistos } \\
\text { pelos leigos, pois eles } \\
\text { assistiram apenas a filmagem } \\
\text { da câmera sobre a lousa que } \\
\text { pega as costas dos estagiários } \\
\text { e os rostos dos alunos) }\end{array}$ \\
\hline 15 & $\begin{array}{l}\text { Estagiário } \\
\text { Adriano }\end{array}$ & $\begin{array}{l}19 \min 41 \mathrm{~s} \\
\mathrm{a} \\
19 \min 44 \mathrm{~s}\end{array}$ & $\begin{array}{l}\text { E o meu fio do outro } \\
\text { lado tava derretendo. }\end{array}$ & \\
\hline 16 & $\begin{array}{l}\text { Diversos } \\
\text { alunos }\end{array}$ & $\begin{array}{l}19 \min 44 s \\
\mathrm{a} \\
19 \min 48 \mathrm{~s}\end{array}$ & $\begin{array}{l}\text { (vários alunos } \\
\text { falando, maior parte é } \\
\text { incompreensível) }\end{array}$ & \\
\hline 17 & Aluno 1 & $19 \min 45 \mathrm{~s}$ & Colocou o fio errado. & $\begin{array}{l}\text { Sentado com as mãos para } \\
\text { trás e pernas jogadas para } \\
\text { frente. }\end{array}$ \\
\hline 18 & $\begin{array}{l}\text { Diversos } \\
\text { alunos }\end{array}$ & $19 \mathrm{~min} 46 \mathrm{~s}$ & $\begin{array}{l}\text { (vários alunos falando } \\
\text { coisas parecidas): } \\
\text { Colocou errado.... } \\
\text { Você fez errado... (...) }\end{array}$ & \\
\hline 19 & Aluna 2 & $19 \mathrm{~min} 46 \mathrm{~s}$ & $\begin{array}{l}\text { Não! Você tinha que } \\
\text { ter ligadoo... }\end{array}$ & $\begin{array}{l}\text { Estagiário Adriano balança a } \\
\text { cabeça para um lado e outro } \\
\text { (em sinal de 'não') }\end{array}$ \\
\hline
\end{tabular}




\begin{tabular}{|c|c|c|c|c|}
\hline 20 & Aluna 2 & 19min48s & $\begin{array}{l}\text { Você ligou pouca } \\
\text { água... você tinha que } \\
\text { ter ligado... }\end{array}$ & $\begin{array}{l}\text { Estagiário Adriano acena com } \\
\text { a mão direita o sinal 'não', } \\
\text { prende fortemente os lábios um }\end{array}$ \\
\hline 21 & $\begin{array}{l}\text { Outra aluna } \\
\text { (não } \\
\text { identificada) }\end{array}$ & $\begin{array}{l}19 \min 49 s \\
\mathrm{a} \\
19 \min 51 \mathrm{~s}\end{array}$ & $\begin{array}{l}\text { Você ligou pouca } \\
\text { água! ...pouca água. }\end{array}$ & $\begin{array}{l}\text { contra o outro, fazendo-os } \\
\text { sumir por quase } 3 \text { segundos } \\
\text { (lábios cerrados) }\end{array}$ \\
\hline 22 & $\begin{array}{l}\text { Estagiário } \\
\text { Fabiano }\end{array}$ & $\begin{array}{l}19 \min 51 \mathrm{~s} \\
\mathrm{a} \\
19 \min 54 \mathrm{~s}\end{array}$ & $\begin{array}{l}\text {...então meu fluxo de } \\
\text { água... tá bem } \\
\text { menor... [fala } \\
\text { pausadamente] }\end{array}$ & $\begin{array}{l}\text { Estagiário Adriano permaneceu } \\
\text { com sorriso fixo e acena com } \\
\text { dedo indicador sinal de } \\
\text { negativo para alguns alunos. }\end{array}$ \\
\hline 23 & Aluno 1 & $\begin{array}{l}19 \min 53 \mathrm{~s} \\
\mathrm{a} \\
19 \min 54 \mathrm{~s}\end{array}$ & $\begin{array}{l}\text { Tá errado! (risos) Vo } \\
\text { cê colocou (fluxo) } \\
\text { errado. Não tinha } \\
\text { capacidade para } \\
\text { isso. (risos) }\end{array}$ & $\begin{array}{l}\text { Aluno } 1 \text { compartilhou sorriso } \\
\text { com dois estagiários que } \\
\text { estavam próximo à porta - } \\
\text { estagiário Arnaldo e estagiário } \\
\text { Abel. } \\
\text { Estagiário Adriano sorri e } \\
\text { acena dedo indicador direito } \\
\text { (em sinal de 'não') para Aluno } \\
1 .\end{array}$ \\
\hline 24 & Aluno 4 & 19min53s & $\begin{array}{l}\text { Não ...é porque o seu } \\
\text { chuveiro .... }\end{array}$ & $\begin{array}{l}\text { Nesse momento o estagiário } \\
\text { Fabiano olha fixamente para o } \\
\text { estagiário Adriano enquanto } \\
\text { este vai em sua direção. } \\
\text { Bastante risos de alguns } \\
\text { alunos e dos estagiários que } \\
\text { estão à porta. }\end{array}$ \\
\hline 25 & Aluna 2 & $\begin{array}{l}19 \min 55 \mathrm{~s} \\
\mathrm{a} \\
19 \min 59 \mathrm{~s}\end{array}$ & $\begin{array}{l}\text {...é a resistência do } \\
\text { chuveiro? É? ...nesse } \\
\text { caso... É? }\end{array}$ & $\begin{array}{l}\text { Estagiário Adriano está } \\
\text { caminhando na direção do } \\
\text { Aluno 4, que iniciava fala. } \\
\text { Aluna } 2 \text { passa a olhar para os } \\
\text { estagiários Arnaldo e Abel que } \\
\text { estavam à porta da sala. } \\
\text { Estagiário Fabiano está } \\
\text { Olhando para os estagiários } \\
\text { Arnaldo e Abel. }\end{array}$ \\
\hline 26 & & $\begin{array}{l}19 \min 57 s \\
a \\
19 \min 59 s\end{array}$ & $\begin{array}{l}\text { Risos (vários alunos e } \\
\text { os estagiários à porta) }\end{array}$ & \\
\hline 27 & Aluno 4 & $\begin{array}{l}19 \min 59 s \\
\text { a } \\
20 \min 00 s\end{array}$ & $\begin{array}{l}\text { Foi a primeira vez que } \\
\text { você fez a instalação } \\
\text { do chuveiro? }\end{array}$ & \\
\hline 28 & $\begin{array}{l}\text { Estagiário } \\
\text { Adriano }\end{array}$ & $\begin{array}{l}20 \min 01 \mathrm{a} \\
20 \min 09 \mathrm{~s}\end{array}$ & $\begin{array}{l}\text { Não! } \\
\text { A .... casa já estava } \\
\text { lá, estava tudo } \\
\text { instalado normal, } \\
\text { aí... acho que isso } \\
\text { foi em janeiro agora. } \\
\text { Eu troquei a } \\
\text { resistência... }\end{array}$ & $\begin{array}{l}\text { Levanta as duas mãos abertas } \\
\text { e gira as duas como breve } \\
\text { 'tchau' }\end{array}$ \\
\hline 29 & Vários alunos & $20 \min 09 s$ & ...do chuveiro? & \\
\hline 30 & $\begin{array}{l}\text { Estagiário } \\
\text { Adriano }\end{array}$ & $20 \min 10 \mathrm{~s}$ & Do chuveiro! & \\
\hline 31 & Aluna 2 & $\begin{array}{l}20 \min 11 \mathrm{~s} \\
\mathrm{a} \\
20 \min 15 \mathrm{~s}\end{array}$ & $\begin{array}{l}\text { Não... Mas você tinha } \\
\text { que ter ligado.... Não! }\end{array}$ & \\
\hline
\end{tabular}




\begin{tabular}{|c|c|c|c|c|}
\hline & & & $\begin{array}{l}\text { Mas você tinha que } \\
\text { ter ligado ele ... }\end{array}$ & \\
\hline 32 & Vários alunos & $\begin{array}{l}20 \min 11 \mathrm{~s} \\
\mathrm{a} \\
20 \min 15 \mathrm{~s}\end{array}$ & $\begin{array}{l}\text { [vários alunos } \\
\text { falando] }\end{array}$ & \\
\hline 33 & $\begin{array}{l}\text { Estagiário } \\
\text { Adriano }\end{array}$ & $20 \min 15 s$ & Calma aí gente! & $\begin{array}{l}\text { Estagiário Adriano levanta as } \\
\text { duas mãos abertas com as } \\
\text { palmas para os alunos }\end{array}$ \\
\hline 34 & Aluno 1 & $\begin{array}{l}20 \min 13 s \\
a \\
20 \min 16 s\end{array}$ & $\begin{array}{l}\text { Você colocou... ... lá } \\
\text { na caixa de luz? Você } \\
\text { trocou lá? }\end{array}$ & $\begin{array}{l}\text { gesticulou com a mão, } \\
\text { indicador e polegar mexendo } \\
\text { em balanço }\end{array}$ \\
\hline 35 & $\begin{array}{l}\text { Estagiário } \\
\text { Adriano }\end{array}$ & 20min16s & Oi? & \\
\hline 36 & Aluno 1 & $20 \min 17 \mathrm{~s}$ & $\begin{array}{l}\text {...colocou menor? } \\
\text {...Você colocou o } \\
\text { menor ou colocou o } \\
\text { maior? }\end{array}$ & \\
\hline 37 & $\begin{array}{l}\text { Estagiário } \\
\text { Adriano }\end{array}$ & $20 \min 18 s$ & O quê? & \\
\hline 38 & Aluno 1 & 20min19s & $\begin{array}{l}\text { Colocou o menor ou } \\
\text { colocou o maior? }\end{array}$ & \\
\hline 39 & $\begin{array}{l}\text { Estagiário } \\
\text { Adriano }\end{array}$ & 20min19s & O quê? & \\
\hline 40 & $\begin{array}{l}\text { Estagiário } \\
\text { Adriano }\end{array}$ & $20 \mathrm{~min} 20 \mathrm{~s}$ & ...lá na potência. & \\
\hline 41 & $\begin{array}{l}\text { Estagiário } \\
\text { Adriano }\end{array}$ & $20 \mathrm{~min} 21 \mathrm{~s}$ & $\begin{array}{l}\text { Coloquei na potência } \\
\text { máxima. }\end{array}$ & \\
\hline 42 & Aluna 2 & 20min23s & $\begin{array}{l}\text {...você tinha que ter } \\
\text { ligado... }\end{array}$ & \\
\hline 43 & Aluno 1 & 20min24s & $\begin{array}{l}\text { Ah! ....então. ....Tá } \\
\text { errado. }\end{array}$ & $\begin{array}{l}\text { Estagiário Adriano dá dois } \\
\text { passos para trás enquanto } \\
\text { continua olhando para alunos e } \\
\text { abaixa a mão. } \\
\text { Coloca a mão direita no bolso } \\
\text { de trás da calça, deixa a mão } \\
\text { esquerda (com o oxímetro) } \\
\text { pendurada na lateral }\end{array}$ \\
\hline 44 & $\begin{array}{l}\text { Estagiário } \\
\text { Fabiano }\end{array}$ & $20 \mathrm{~min} 25 \mathrm{~s}$ & $\begin{array}{l}\text { Supostamente foi } \\
\text { instalado } \\
\text { corretamente... o } \\
\text { chuveiro.... a } \\
\text { instalação tá correta } \\
\text { de acordo com as } \\
\text { especificações lá. }\end{array}$ & $\begin{array}{l}\text { [estava com as mãos cruzadas } \\
\text { junto à cintura, soltou as mãos } \\
\text { e enquanto segurava } \\
\text { resistência com a mão } \\
\text { esquerda, com a direita aberta } \\
\text { e polegar na normal faz um } \\
\text { semicírculo enquanto falava] } \\
\text { [Terminou a fala, olhando e se } \\
\text { aproximando do Aluno 1, } \\
\text { repetindo "...se a instalação tá } \\
\text { correta" (aos 20:24), e cerrando } \\
\text { os lábios] }\end{array}$ \\
\hline 45 & Aluna 2 & $\begin{array}{l}20 \min 25 s \\
\mathrm{a} \\
20 \min 40 \mathrm{~s}\end{array}$ & $\begin{array}{l}\text {.... primeiro } \\
\text { você tinha que ter } \\
\text { ligado ele } \\
\text { antes... antes de ter } \\
\text { ligando da energia, } \\
\text { assim... tinha que ter } \\
\text { ligado ele.....na } \\
\text { água... pra depois }\end{array}$ & $\begin{array}{l}\text { Estagiário Adriano permanece } \\
\text { com a mão direita no bolso de } \\
\text { trás da calça. (após várias } \\
\text { tentativas de falar, estava } \\
\text { sendo ouvida pelo estagiário } \\
\text { Adriano enquanto o estagiário } \\
\text { Fabiano está terminando de } \\
\text { falar próximo ao Aluno } 1 \text {, que }\end{array}$ \\
\hline
\end{tabular}




\begin{tabular}{|c|c|c|c|c|}
\hline & & & $\begin{array}{l}\text { você ligar ele } \\
\text { normal... como fosse } \\
\text { normal, usar. }\end{array}$ & $\begin{array}{l}\text { está ao lado da aluna 2) } \\
\text { [estagiário Adriano está } \\
\text { prestando atenção na aluna e } \\
\text { ficou sério com a mão direita } \\
\text { para trás, no bolso - a mão } \\
\text { esquerda está com o oxímetro] }\end{array}$ \\
\hline 46 & Aluno 1 & 20min27s & (riso) & $\begin{array}{l}\text { Aluno } 1 \text { está rindo, olhando } \\
\text { para o estagiário Fabiano, } \\
\text { passa mão direita do alto da } \\
\text { cabeça até a nuca] obs.: } \\
\text { nesse momento, } \\
\text { aparentemente, Estagiário } \\
\text { Adriano gesticula com os lábios } \\
\text { a palavra 'supostamente'. }\end{array}$ \\
\hline 47 & $\begin{array}{l}\text { Estagiário } \\
\text { Adriano }\end{array}$ & 20min40s & & $\begin{array}{l}\text { [Estagiário Adriano para por um } \\
\text { segundo, acena a cabeça 'sim'; } \\
\text { está sério] }\end{array}$ \\
\hline 48 & $\begin{array}{l}\text { Estagiário } \\
\text { Adriano }\end{array}$ & $\begin{array}{l}20 \min 41 s \\
\text { a } \\
20 \min 43 s\end{array}$ & $\begin{array}{l}\text { Todo mundo ouviu...? } \\
\text {... que a colega } \\
\text { falou? }\end{array}$ & $\begin{array}{l}\text { Estagiário Adriano permanece } \\
\text { com a mão direita no bolso de } \\
\text { trás da calça e nesse momento } \\
\text { aponta dedo indicador da mão } \\
\text { esquerda para a Aluna } 2 \text {, ao } \\
\text { término de sua fala. [só estava } \\
\text { tendo a fala da Aluna } 2 \text { e todos } \\
\text { estavam prestando atenção] } \\
\text { [parou novamente por um } \\
\text { instante, apontando para ela } \\
\text { enquanto respira mais fundo, } \\
\text { até que um aluno começou a } \\
\text { falar e então aponta para esse } \\
\text { aluno] }\end{array}$ \\
\hline 49 & Aluna 2 & $\begin{array}{l}20 \min 44 s \\
a \\
20 \min 47 s\end{array}$ & $\begin{array}{l}\text {...porque se não você } \\
\text { queima o chuveiro } \\
\text { mesmo. }\end{array}$ & \\
\hline 50 & Aluno 4 & $\begin{array}{l}20 \min 46 s \\
\mathrm{a} \\
20 \min 48 \mathrm{~s}\end{array}$ & $\begin{array}{l}\text { Primeiro tem.... } \\
\text { Primeiro você liga o } \\
\text { chuveiro no frio... }\end{array}$ & $\begin{array}{l}\text { [estagiário Adriano estava com } \\
\text { sorriso tímido, fixo; com a mão } \\
\text { direita no bolso de trás da } \\
\text { calça] }\end{array}$ \\
\hline 51 & Aluna 2 & 20min49s & É! & \\
\hline 52 & Aluno 4 & $\begin{array}{l}20 \min 51 \mathrm{a} \\
21 \mathrm{~min} 07 \mathrm{~s}\end{array}$ & $\begin{array}{l}\text {...pra depois você } \\
\text { desligar e botar no } \\
\text { botão quente, pra ele } \\
\text { aquecer }\end{array}$ & $\begin{array}{l}\text { enquanto Aluno } 4 \text { estava } \\
\text { terminando, estava com sorriso } \\
\text { e com a mão direita no bolso } \\
\text { de trás da calça }\end{array}$ \\
\hline 53 & $\begin{array}{l}\text { Estagiário } \\
\text { Fabiano }\end{array}$ & 20min56s & Verdade! & $\begin{array}{l}\text { Balança a cabeça com ‘sim', } \\
\text { voltando-se para o Aluno } 4 . \\
\text { Tossiu e ficou olhando } \\
\text { fixamente para o estagiário } \\
\text { Adriano. }\end{array}$ \\
\hline 54 & $\begin{array}{l}\text { Estagiário } \\
\text { Adriano }\end{array}$ & $\begin{array}{l}20 \min 55 s \\
a \\
20 \min 58 s\end{array}$ & $\begin{array}{l}\text { Tudo que vocês estão } \\
\text { falando, de certa } \\
\text { forma tá correto. }\end{array}$ & $\begin{array}{l}\text { As duas mãos abertas, à } \\
\text { frente, com as palmas voltadas } \\
\text { para baixo. }\end{array}$ \\
\hline 55 & $\begin{array}{l}\text { Estagiário } \\
\text { Adriano }\end{array}$ & 20min59s & $\begin{array}{l}\text {...só que tem um } \\
\text { outro fator que } \\
\text { ninguém comentou... }\end{array}$ & \\
\hline
\end{tabular}




\begin{tabular}{|c|c|c|c|c|}
\hline 56 & $\begin{array}{l}\text { Aluno (outro, } \\
\text { não } \\
\text { identificado) }\end{array}$ & $21 \min 01 \mathrm{~s}$ & Estava calor? & \\
\hline 57 & Aluno 5 & $21 \min 02 s$ & ...a resistência? & \\
\hline 58 & $\begin{array}{l}\text { Aluna (outra, } \\
\text { não } \\
\text { identificada) }\end{array}$ & $21 \mathrm{~min} 04 \mathrm{~s}$ & ...pouca água? & \\
\hline 59 & $\begin{array}{l}\text { Estagiário } \\
\text { Adriano }\end{array}$ & $21 \mathrm{~min} 04 \mathrm{~s}$ & & $\begin{array}{l}\text { [fez uma parada momentânea, } \\
\text { silêncio] }\end{array}$ \\
\hline 60 & $\begin{array}{l}\text { Estagiário } \\
\text { Adriano }\end{array}$ & $21 \mathrm{~min} 05 \mathrm{~s}$ & $\begin{array}{l}\text { A água já estava } \\
\text { quente! }\end{array}$ & $\begin{array}{l}\text { Estagiário Fabiano, que estava } \\
\text { segurando a resistência com as } \\
\text { duas mãos e com o corpo } \\
\text { parado na mesma posição, } \\
\text { solta abruptamente os dois } \\
\text { braços e mãos para junto das } \\
\text { laterais do corpo e olha para o } \\
\text { estagiário Adriano. }\end{array}$ \\
\hline 61 & Aluna 6 & $21 \mathrm{~min} 07 \mathrm{~s}$ & Aã!? & $\begin{array}{l}\text { Aluna } 6 \text { expressa som de } \\
\text { espanto. Obs.: Foi a primeira } \\
\text { vez que essa aluna emitiu } \\
\text { algum som ou falou alguma } \\
\text { coisa. } \\
\text { Em seguida, a Aluna 6, } \\
\text { juntamente com o estagiário } \\
\text { Adriano, aponta para o } \\
\text { estagiário Fabiano e põe a mão } \\
\text { esquerda fechada apoiando a } \\
\text { lateral do queixo e com } \\
\text { cotovelo apoiado na carteira e } \\
\text { fica prestando atenção na fala } \\
\text { do estagiário Adriano. }\end{array}$ \\
\hline 62 & $\begin{array}{l}\text { Estagiário } \\
\text { Adriano }\end{array}$ & $\begin{array}{l}21 \min 08 s \\
a \\
21 \min 13 s\end{array}$ & $\begin{array}{l}\text { Ele não falou de } \\
\text { Campos do Jordão? } \\
\text { Qual que é a } \\
\text { temperatura da água } \\
\text { lá? ...por exemplo? }\end{array}$ & $\begin{array}{l}\text { apontando para estagiário } \\
\text { Fabiano }\end{array}$ \\
\hline 63 & $\begin{array}{l}\text { Estagiário } \\
\text { Fabiano }\end{array}$ & $21 \min 13 \mathrm{~s}$ & Quase zero! & $\begin{array}{l}\text { [cruza as pernas, como se } \\
\text { estivesse com vontade de } \\
\text { urinar e esticando a mão } \\
\text { esquerda e abrindo o braço } \\
\text { esquerdo] }\end{array}$ \\
\hline 64 & $\begin{array}{l}\text { Aluno (outro, } \\
\text { não } \\
\text { identificado) }\end{array}$ & $21 \min 14 s$ & $\begin{array}{l}\text {....mais. ...Abaixo de } \\
\text { zero. }\end{array}$ & \\
\hline 65 & $\begin{array}{l}\text { Estagiário } \\
\text { Fabiano }\end{array}$ & $21 \min 16 s$ & $\begin{array}{l}\text { Abaixo de } \\
\text { zero.... certas épocas } \\
\text { do ano. }\end{array}$ & $\begin{array}{l}\text { Descruza as pernas, balança } \\
\text { intensamente a cabeça (e parte } \\
\text { do corpo) sinalizando 'sim' e } \\
\text { olha para o estagiário Adriano. }\end{array}$ \\
\hline 66 & $\begin{array}{l}\text { Estagiário } \\
\text { Adriano }\end{array}$ & $21 \min 18 \mathrm{~s}$ & É! & $\begin{array}{l}\text { [balança a cabeça } \\
\text { aparentemente representando } \\
\text { dúvida, olhando para aluno e } \\
\text { em seguida olhando para o } \\
\text { estagiário Fabiano] }\end{array}$ \\
\hline 67 & $\begin{array}{l}\text { Estagiário } \\
\text { Adriano }\end{array}$ & $\begin{array}{l}\text { (há um } \\
\text { pulo de } \\
\text { cerca de } \\
\text { 1s no }\end{array}$ & $\begin{array}{l}\text { Na minha casa a } \\
\text { água já estava... já } \\
\text { estava basicamente } \\
\text { fervida. O que que eu }\end{array}$ & $\begin{array}{l}\text { sorrindo e fazendo movimento } \\
\text { com as mãos, como se } \\
\text { quisesse representar um } \\
\text { recipiente com água. }\end{array}$ \\
\hline
\end{tabular}




\begin{tabular}{|c|c|c|c|c|}
\hline & & $\begin{array}{l}\text { vídeo da } \\
\text { câmera } \\
\text { voltada } \\
\text { para os } \\
\text { alunos) - } \\
\text { termina } \\
\text { em } \\
21 \text { min37s }\end{array}$ & $\begin{array}{l}\text { fiz? Eu coloquei... fiz } \\
\text { essa água quente } \\
\text { passar pelo } \\
\text { chuveiro.... e aí tinha } \\
\text { um elemento que ia } \\
\text { fazer ela esquentar } \\
\text { mais ainda... O que } \\
\text { aconteceu? Uma } \\
\text { demanda de corrente } \\
\text { elétrica maior do que } \\
\text { o fio aguentava. Tudo } \\
\text { bem? Na minha casa } \\
\text { eu dimensionei um fio } \\
\text { de } 4 \text { mm de secção } \\
\text { transversal que a } \\
\text { gente fala né, de } \\
\text { bitola. Esse é um fio } \\
\text { adequado pra um } \\
\text { chuveiro até } 6500 \\
\text { watts... }\end{array}$ & $\begin{array}{l}\text { Levanta rapidamente o ombro } \\
\text { direito. (no quadro a quadro é } \\
\text { perceptível }\end{array}$ \\
\hline 68 & $\begin{array}{l}\text { Estagiário } \\
\text { Fabiano }\end{array}$ & $21 \min 37 \mathrm{~s}$ & ... que é a potência... & $\begin{array}{l}\text { [apontou a mão para o } \\
\text { estagiário Adriano e em } \\
\text { seguida para os alunos] [Aluno } \\
1 \text { está rindo] }\end{array}$ \\
\hline 69 & $\begin{array}{l}\text { Estagiário } \\
\text { Adriano }\end{array}$ & $\begin{array}{l}21 \min 38 s \\
\mathrm{a} \\
21 \min 47 \mathrm{~s}\end{array}$ & $\begin{array}{l}\text {...que é a potência! } \\
\text { Se eu quiser colocar } \\
\text { um de } 7500, \text { é um fio } \\
\text { de } 6 \text { mm. Tudo bem? } \\
\text { Isso aqui são só... } \\
\text { coisas da... da.... da } \\
\text { profissão.... }\end{array}$ & $\begin{array}{l}\text { aponta para o estagiário } \\
\text { Fabiano e começou gesticular } \\
\text { bastante com as mãos } \\
\text { [próximo ao final da fala do } \\
\text { estagiário Adriano, Aluno } 1 \\
\text { voltou a dar risada - abriu os } \\
\text { braços e iniciou a fala com } \\
\text { sorriso constante no rosto] }\end{array}$ \\
\hline 70 & $\begin{array}{l}\text { Estagiário } \\
\text { Adriano }\end{array}$ & $\begin{array}{l}21 \min 48 \mathrm{~s} \\
\mathrm{a} \\
22 \min 04 \mathrm{~s}\end{array}$ & $\begin{array}{l}\text {...Eu sabia que aquele } \\
\text { fio aguentava, só que } \\
\text { o que eu fiz? Qual foi } \\
\text { meu erro? A água já } \\
\text { estava quente. Se eu } \\
\text { coloquei na potência } \\
\text { máxima, eu fiz o } \\
\text { resistor ter uma } \\
\text { demanda maior de } \\
\text { corrente. Dei uma } \\
\text { torrada no meu fio. E } \\
\text { torrou o... o... } \\
\text { terminal do... do } \\
\text { disjuntor também. O } \\
\text { que eu tive que fazer? } \\
\text { Trocar o disjuntor. }\end{array}$ & $\begin{array}{l}\text { Estagiário está com sorriso fixo } \\
\text { no rosto. }\end{array}$ \\
\hline 71 & $\begin{array}{l}\text { Estagiário } \\
\text { Fabiano }\end{array}$ & $22 \mathrm{~min} 04 \mathrm{~s}$ & ...então & $\begin{array}{l}\text { quase interrompendo o } \\
\text { estagiário Adriano, apontando } \\
\text { para ele] }\end{array}$ \\
\hline 72 & $\begin{array}{l}\text { Estagiário } \\
\text { Adriano }\end{array}$ & $\begin{array}{l}22 \min 04 s \\
\text { a } \\
22 \min 16 s\end{array}$ & $\begin{array}{l}\text {...da próxima vez, } \\
\text { como uns de... como } \\
\text { alguns de vocês } \\
\text { falaram... quando eu } \\
\text { trocar de }\end{array}$ & $\begin{array}{l}\text { [sorrindo, começa a mexer na } \\
\text { aliança] Aluno } 1 \text { está rindo } \\
\text { também. }\end{array}$ \\
\hline
\end{tabular}




\begin{tabular}{|c|c|c|c|c|}
\hline & & & $\begin{array}{l}\text { novo... é mais fácil eu } \\
\text { colocar na... } \\
\text { temperatura morna... } \\
\text { não vou ter uma } \\
\text { demanda tão alta de } \\
\text { corrente elétrica. } \\
\text { Tudo bem? }\end{array}$ & $\begin{array}{l}\text { Obs.: não foi identificado em } \\
\text { nenhum ponto dos vídeos (das } \\
\text { duas câmeras) a colocacãão de } \\
\text { algum aluno sugerindo ligar o } \\
\text { chuveiro na posição 'morna'. } \\
\text { Todos que questionaram o } \\
\text { estagiário Adriano afirmaram } \\
\text { que o chuveiro primeiro tem de } \\
\text { ser ligado na posição 'fria'. } \\
\text { Nesse momento, Aluno } 1 \text { põe } \\
\text { mão direita fechada apoiada na } \\
\text { lateral do queixo e com o } \\
\text { cotovelo apoiado na carteira e } \\
\text { abaixa a cabeça. }\end{array}$ \\
\hline 73 & $\begin{array}{l}\text { Estagiário } \\
\text { Adriano }\end{array}$ & $\begin{array}{l}22 \min 16 s \\
\mathrm{a} \\
22 \mathrm{~min} 21 \mathrm{~s}\end{array}$ & $\begin{array}{l}\text {...basicamente isso. } \\
\text { Isso é um exemplo do } \\
\text { dia a dia que } \\
\text { aconteceu comigo. }\end{array}$ & $\begin{array}{l}\text { Estagiário está novamente com } \\
\text { sorriso fixo e olha para aluno } \\
\text { que deu risada. }\end{array}$ \\
\hline 74 & $\begin{array}{l}\text { Estagiário } \\
\text { Fabiano }\end{array}$ & $\begin{array}{l}\text { 22min21s } \\
\text { a } \\
22 \mathrm{~min} 36 \mathrm{~s} \\
\text { (para as } \\
\text { anotações } \\
\text { não } \\
\text { verbais; } \\
\text { mas o } \\
\text { diálogo } \\
\text { continua } \\
\text { fechando } \\
\text { a } \\
\text { dinâmica } \\
\text { do início } \\
\text { da aula) }\end{array}$ & $\begin{array}{l}\text { Então, turma.... } \\
\text { Assim.... } \\
\text {...de acordo com toda } \\
\text { essa discussão que a } \\
\text { gente fez aqui. Todos } \\
\text { esses fenômenos que } \\
\text { a gente apresentou } \\
\text { pra vocês.... } \\
\text {....tudo isso aqui que } \\
\text { vocês falaram que } \\
\text { você precisa levar em } \\
\text { consideração, ao } \\
\text { fazer a escolha do } \\
\text { seu chuveiro (...) }\end{array}$ & $\begin{array}{l}\text { Estagiário Adriano mexe na } \\
\text { aliança, retira celular do bolso, } \\
\text { olha para Estagiário Fabiano, } \\
\text { escuta fala de um aluno, mas } \\
\text { não responde, dá um passo à } \\
\text { frente sorrindo, pára } \\
\text { bruscamente e vira-se de } \\
\text { costas para os alunos sorrindo, } \\
\text { guarda o celular e vai em } \\
\text { direção à lousa. Faz um traço } \\
\text { qualquer na lousa (sem } \\
\text { nenhum motivo perceptível de } \\
\text { ordem didática ou } \\
\text { organizacional da } \\
\text { lousa). Nesse momento, para } \\
\text { de sorrir e fica com semblante } \\
\text { sério. Aluno 1, que estava com } \\
\text { polegar e indicador direitos na } \\
\text { ponta do queixo, colocou a } \\
\text { planta da mão direita na lateral } \\
\text { da boca e cochichou algo para } \\
\text { a Aluna 2, que também falou } \\
\text { algo, e começaram a sorrir - } \\
\text { Estagiário Adriano e Estagiário } \\
\text { Fabiano também riram } \\
\text { aparentemente pelo mesmo } \\
\text { motivo] }\end{array}$ \\
\hline
\end{tabular}




\section{APÊNDICE B: TRANSCRIÇÃO DO EPISÓDIO 2}

\begin{tabular}{|c|c|c|c|c|}
\hline \multicolumn{5}{|c|}{ Episódio 2} \\
\hline Linha & Participante & Tempo & Processos verbais & Processos não verbais \\
\hline 1 & $\begin{array}{l}\text { Estagiário } \\
\text { Arnaldo }\end{array}$ & $\begin{array}{l}4 \min 15 s \\
\mathrm{a} \\
4 \min 25 s\end{array}$ & $\begin{array}{l}\text { Então, pessoal! } \\
\text { Revisão da aula } \\
\text { passada. Né... Ele } \\
\text { falou sobre as ideias } \\
\text {.... do calor, né. Calor, } \\
\text { como ele escreveu } \\
\text { aqui na lousa, né... o } \\
\text { que que é? É a } \\
\text { transferência de } \\
\text { energia térmica de um } \\
\text { corpo para outro. Né! }\end{array}$ & $\begin{array}{l}\text { O estagiário Abel está } \\
\text { escrevendo na lousa, anotações } \\
\text { de um papel que tem na mão. } \\
\text { O estagiário Arnaldo está à } \\
\text { frente da classe e voltado para } \\
\text { os alunos e aponta para a lousa. } \\
\text { Estagiário Arnaldo move-se } \\
\text { bastante de um lado para o outro } \\
\text { da sala enquanto fala. }\end{array}$ \\
\hline 2 & $\begin{array}{l}\text { Estagiário } \\
\text { Arnaldo }\end{array}$ & $\begin{array}{l}4 \min 25 s \\
a \\
4 \min 30 s\end{array}$ & $\begin{array}{l}\text { Por exemplo, aqui. } \\
\text { Estão os dois corpos } \\
\text { aqui, né. }\end{array}$ & $\begin{array}{l}\text { Estagiário Arnaldo para próximo } \\
\text { à lousa e ao estagiário Abel que } \\
\text { estava escrevendo, vira-se. } \\
\text { Estagiário Arnaldo aponta para si } \\
\text { e em seguida para o estagiário } \\
\text { Abel. }\end{array}$ \\
\hline 3 & $\begin{array}{l}\text { Estagiário } \\
\text { Arnaldo }\end{array}$ & $\begin{array}{l}4 \min 30 s \\
\mathrm{a} \\
4 \mathrm{~min} 33 \mathrm{~s}\end{array}$ & $\begin{array}{l}\text { Ah! tá. (falas dos } \\
\text { estagiários e várias } \\
\text { falas dos alunos, } \\
\text { inaudíveis) (risos). }\end{array}$ & $\begin{array}{l}\text { Estagiários ficam lado a lado, } \\
\text { com ombros encostados um no } \\
\text { outro, trocando olhares. Em } \\
\text { seguida se afastam um pouco e } \\
\text { o estagiário Arnaldo inclina a } \\
\text { cabeça rapidamente para os dois } \\
\text { lados dos ombros. }\end{array}$ \\
\hline 4 & $\begin{array}{l}\text { Estagiário } \\
\text { Arnaldo }\end{array}$ & $\begin{array}{l}4 \min 33 s \\
a \\
4 \min 37 s\end{array}$ & $\begin{array}{l}\text { O que acontece? Para } \\
\text { haver calor, tem que } \\
\text { haver uma } \\
\text { transferência de.. de } \\
\text { um corpo ..., né, tem } \\
\text { que haver } \\
\text { transferência de um } \\
\text { corpo ... }\end{array}$ & $\begin{array}{l}\text { Estagiário Abel volta a escrever } \\
\text { na lousa e estagiário Arnaldo } \\
\text { está falando e aponta com as } \\
\text { duas mãos para si. }\end{array}$ \\
\hline 5 & $\begin{array}{l}\text { Estagiário } \\
\text { Arnaldo }\end{array}$ & $4 \min 37 s$ & ....para outro & $\begin{array}{l}\text { Aponta para o estagiário Abel } \\
\text { enquanto este está de costas } \\
\text { escrevendo na lousa. }\end{array}$ \\
\hline 6 & $\begin{array}{l}\text { Estagiário } \\
\text { Arnaldo }\end{array}$ & $4 \mathrm{~min} 37 \mathrm{~s}$ & $\begin{array}{l}\text { E a transferência do } \\
\text { calor... }\end{array}$ & Abre os braços. \\
\hline 7 & $\begin{array}{l}\text { Estagiário } \\
\text { Arnaldo }\end{array}$ & $\begin{array}{l}4 \min 38 s \\
\mathrm{a} \\
4 \mathrm{~min} 40 \mathrm{~s}\end{array}$ & $\begin{array}{l}\text {...é sempre de um } \\
\text { corpo mais quente... } \\
\text { [aumenta o tom no } \\
\text { final da frase] }\end{array}$ & $\begin{array}{l}\text { Aponta fortemente para si com } \\
\text { as duas mãos e abaixa a cabeça } \\
\text { rapidamente. }\end{array}$ \\
\hline 8 & $\begin{array}{l}\text { Estagiário } \\
\text { Arnaldo }\end{array}$ & $\begin{array}{l}4 \min 40 s \\
\mathrm{a} \\
4 \min 43 \mathrm{~s}\end{array}$ & $\begin{array}{l}\text {...para um corpo mais } \\
\text { frio. }\end{array}$ & $\begin{array}{l}\text { Dá um passo para o lado, se } \\
\text { aproximando mais do estagiário } \\
\text { Abel e aponta as duas mãos } \\
\text { para este. Estagiário Abel vira }\end{array}$ \\
\hline
\end{tabular}




\begin{tabular}{|c|c|c|c|c|}
\hline & & & & $\begin{array}{l}\text { apenas o rosto para o estagiário } \\
\text { Arnaldo e para a classe, parando } \\
\text { de escrever na lousa e fazendo } \\
\text { gesto com mão que segura } \\
\text { papel inicialmente para si e } \\
\text { depois para o estagiário Arnaldo. } \\
\text { Move a cabeça como se } \\
\text { acompanhasse a fala do } \\
\text { estagiário Arnaldo. }\end{array}$ \\
\hline 9 & Aluno 1 & $\begin{array}{l}4 \min 43 s \\
a \\
4 \min 47 s\end{array}$ & $\begin{array}{l}\text { Ou seja.... ou seja... } \\
\text { (falas inaudíveis) - } \\
\text { muitos risos. }\end{array}$ & $\begin{array}{l}\text { Muitos risos dos alunos. } \\
\text { Estagiários estão se olhando e } \\
\text { sorrindo um para o outro. }\end{array}$ \\
\hline 10 & $\begin{array}{l}\text { Estagiário } \\
\text { Arnaldo }\end{array}$ & $\begin{array}{l}4 \min 47 s \\
\text { a } \\
4 \min 49 s\end{array}$ & $\begin{array}{l}\text {...(fala inaudível) } \\
\text { muitos risos. ...Eu } \\
\text { pego fogo aqui! }\end{array}$ & $\begin{array}{l}\text { Estagiário gira rapidamente } \\
\text { várias vezes o braço direito em } \\
\text { círculo junto a lateral do corpo. } \\
\text { Classe está rindo bastante. }\end{array}$ \\
\hline 11 & Aluna 2 & $\begin{array}{l}4 \min 50 s \\
\text { a } \\
4 \min 52 s\end{array}$ & Você é aquecido! & Muitos risos. \\
\hline 12 & $\begin{array}{l}\text { Estagiário } \\
\text { Arnaldo }\end{array}$ & $\begin{array}{l}4 \min 52 s \\
\mathrm{a} \\
4 \min 53 \mathrm{~s}\end{array}$ & Eu sou aquecido! & $\begin{array}{l}\text { Estagiário Arnaldo dá passos } \\
\text { para frente e para trás várias } \\
\text { vezes e pequenos chutes no ar. }\end{array}$ \\
\hline 13 & $\begin{array}{l}\text { Estagiário } \\
\text { Arnaldo }\end{array}$ & $\begin{array}{l}4 \min 53 s \\
\text { a } \\
4 \min 57 s\end{array}$ & $\begin{array}{l}\text { Entendeu? Tudo } \\
\text { bem? Calor? Todo } \\
\text { mundo lembra...? }\end{array}$ & $\begin{array}{l}\text { Estagiário Abel continua } \\
\text { escrevendo na lousa e o } \\
\text { estagiário Arnaldo está com } \\
\text { olhando para classe e movendo } \\
\text { a cabeça para cima e para baixo. } \\
\text { A vários alunos continuam rindo } \\
\text { e fazendo comentários } \\
\text { (inaudíveis). }\end{array}$ \\
\hline 14 & $\begin{array}{l}\text { Estagiário } \\
\text { Arnaldo }\end{array}$ & $4 \min 58 \mathrm{~s}$ & O que é calor? & \\
\hline 15 & Aluna 2 & $\begin{array}{l}4 \min 58 \mathrm{~s} \\
\mathrm{a} \\
5 \mathrm{~min} 00 \mathrm{~s}\end{array}$ & $\begin{array}{l}\text { Todo mundo tava na } \\
\text { aula dele. }\end{array}$ & \multirow{2}{*}{$\begin{array}{l}\text { Ainda há vários risos na classe e } \\
\text { alguns alunos estão comentando } \\
\text { algo com o estagiário Abel, que } \\
\text { se volta para a classe e ri com os } \\
\text { alunos. } \\
\text { Estagiário Arnaldo para de } \\
\text { conversar falar com alguns } \\
\text { alunos e há bastante risos na } \\
\text { classe. }\end{array}$} \\
\hline 16 & $\begin{array}{l}\text { Estagiário } \\
\text { Arnaldo }\end{array}$ & $\begin{array}{l}5 \min 00 \mathrm{~s} \\
\mathrm{a} \\
5 \min 10 \mathrm{~s}\end{array}$ & $\begin{array}{l}\text { Ah! Você não sabe? } \\
\text { (enquanto aponta } \\
\text { para um aluno que } \\
\text { falou algo inaudível) }\end{array}$ & \\
\hline 17 & $\begin{array}{l}\text { Estagiário } \\
\text { Arnaldo }\end{array}$ & $\begin{array}{l}5 \min 10 \mathrm{~s} \\
\mathrm{a} \\
5 \min 12 \mathrm{~s}\end{array}$ & $\begin{array}{l}\text { Quem não estava na } \\
\text { aula passada? }\end{array}$ & $\begin{array}{l}\text { Estagiário Abel volta a escrever } \\
\text { na lousa e estagiário Arnaldo } \\
\text { aponta para alguns alunos, ainda } \\
\text { rindo um pouco. }\end{array}$ \\
\hline
\end{tabular}




\section{APÊNDICE C: TRANSCRIÇÃO DO EPISÓDIO 3}

\begin{tabular}{|c|c|c|c|c|}
\hline \multicolumn{5}{|c|}{ Episódio 3} \\
\hline Linha & Participante & Tempo & Processos verbais & Processos não verbais \\
\hline 1 & $\begin{array}{l}\text { Estagiário } \\
\text { Abel }\end{array}$ & $\begin{array}{l}00 \min 54 \mathrm{~s} \\
\mathrm{a} \\
01 \min 23 \mathrm{~s}\end{array}$ & $\begin{array}{l}\text { [explicando situações } \\
\text { físicas de troca de calor } \\
\text { aparentemente para } \\
\text { grupo de três ou quatro } \\
\text { alunos próximos à porta] }\end{array}$ & $\begin{array}{l}\text { Estagiário Abel está sentado } \\
\text { na primeira carteira da terceira } \\
\text { fileira, de lado para a classe e } \\
\text { de frende para um grupo de } \\
\text { três ou quatro alunos. } \\
\text { Estagiário Arnaldo está } \\
\text { enchendo dois balões de } \\
\text { festas, um com ar e outro com } \\
\text { água, move-se para um lado e } \\
\text { para outro com os balões, olha } \\
\text { pelos balões contra a luz. }\end{array}$ \\
\hline 2 & $\begin{array}{l}\text { Estagiário } \\
\text { Abel }\end{array}$ & $\begin{array}{l}\text { 01min23s } \\
\text { a } \\
01 \min 31 \mathrm{~s}\end{array}$ & Beleza!? & $\begin{array}{l}\text { Estagiário Abel termina } \\
\text { conversa com grupo de alunos } \\
\text { e se vira e olha para estagiário } \\
\text { Arnaldo enquanto este está } \\
\text { terminando de preparar os } \\
\text { balões para experimento. Em } \\
\text { seguida desce da carteira e } \\
\text { vai em direção à mesa com os } \\
\text { materiais e comenta algo com } \\
\text { o estagiário Arnaldo. }\end{array}$ \\
\hline 3 & $\begin{array}{l}\text { Estagiário } \\
\text { Arnaldo }\end{array}$ & $\begin{array}{l}01 \min 33 s \\
\text { a } \\
01 \min 36 s\end{array}$ & $\begin{array}{l}\text { Pessoal!? ...é! ....eu não } \\
\text { estou brincando com } \\
\text { balão não, tá! Vocês já } \\
\text { vão entender. }\end{array}$ & $\begin{array}{l}\text { Olhando contra a luz para um } \\
\text { dos balões que segura nas } \\
\text { mãos. }\end{array}$ \\
\hline 4 & $\begin{array}{l}\text { Estagiário } \\
\text { Arnaldo }\end{array}$ & \begin{tabular}{|l|}
$01 \min 39 s$ \\
$\mathrm{a}$ \\
$01 \min 40 \mathrm{~s}$ \\
\end{tabular} & $\begin{array}{l}\text { A... brincadeira aqui é o } \\
\text { seguinte.... }\end{array}$ & $\begin{array}{l}\text { Mexe no balão que tem à mão } \\
\text { enquanto fala. }\end{array}$ \\
\hline 5 & $\begin{array}{l}\text { Estagiário } \\
\text { Arnaldo }\end{array}$ & $\begin{array}{l}\text { 01min40s } \\
\text { a } \\
01 \min 47 s\end{array}$ & $\begin{array}{l}\text { Temos um balão aqui... } \\
\text { Oh! Nosso amigo ali tem } \\
\text { pavor de balão, tá. }\end{array}$ & $\begin{array}{l}\text { Move a cabeça para cima e } \\
\text { para o lado, como se quisesse } \\
\text { indicar o aluno sentado } \\
\text { próximo às janelas da classe. } \\
\text { Estagiário Abel foi até a mesa } \\
\text { do professor e sentou no canto } \\
\text { da mesa segurando outro } \\
\text { balão que estava sobre a } \\
\text { mesa. }\end{array}$ \\
\hline 6 & $\begin{array}{l}\text { Estagiário } \\
\text { Abel }\end{array}$ & $\begin{array}{l}01 \min 48 \mathrm{~s} \\
\mathrm{a} \\
01 \min 55 \mathrm{~s}\end{array}$ & $\begin{array}{l}\text { (fala inaudível) Quem... } \\
\text { (inaudível)? }\end{array}$ & \\
\hline 7 & Aluna 3 & 01min55s & Eu. & $\begin{array}{l}\text { Aluna } 4 \text { aponta para aluna } 3 . \\
\text { Estagiário Abel está } \\
\text { segurando um balão de } \\
\text { tamanho maior que o }\end{array}$ \\
\hline
\end{tabular}




\begin{tabular}{|c|c|c|c|c|}
\hline & & & & $\begin{array}{l}\text { segurando pelo estagiário } \\
\text { Arnaldo. }\end{array}$ \\
\hline 8 & $\begin{array}{l}\text { Estagiário } \\
\text { Abel }\end{array}$ & $\begin{array}{l}01 \min 55 \mathrm{~s} \\
\mathrm{a} \\
01 \min 57 \mathrm{~s}\end{array}$ & Você? & $\begin{array}{l}\text { Levanta-se da mesa do } \\
\text { professor e começa a } \\
\text { caminhar em direção à Aluna } \\
3 \text { segurando o balão numa } \\
\text { mão e acendendo um isqueiro } \\
\text { com a outra. }\end{array}$ \\
\hline 9 & Aluna 3 & $\begin{array}{l}01 \min 57 \mathrm{~s} \\
\mathrm{a} \\
02 \min 00 \mathrm{~s}\end{array}$ & $\begin{array}{l}\text { Não vem aqui não! Pelo } \\
\text { amor de Deus! }\end{array}$ & $\begin{array}{l}\text { Aluna } 3 \text { está sentada de lado } \\
\text { encostada na parede das } \\
\text { janelas e vira o rosto para o } \\
\text { lado (para colega da carteira } \\
\text { de trás), põe as mãos no rosto } \\
\text { (sobre o nariz e abaixo do } \\
\text { olho). }\end{array}$ \\
\hline 10 & $\begin{array}{l}\text { Estagiário } \\
\text { Abel }\end{array}$ & $\begin{array}{l}02 \mathrm{~min} 00 \mathrm{~s} \\
\mathrm{a} \\
02 \mathrm{~min} 02 \mathrm{~s}\end{array}$ & $\begin{array}{l}\text { Vou ficar aqui pertinho } \\
\text { de você, tá!? }\end{array}$ & $\begin{array}{l}\text { Estagiário Abel chega à } \\
\text { carteira à frente dela e senta } \\
\text { na carteira segurando o balão } \\
\text { com o braço estendido, } \\
\text { enquanto Aluna } 3 \text { permanece } \\
\text { com as mãos na mesma } \\
\text { posição do rosto. [risos na } \\
\text { classe] Estagiário Arnaldo está } \\
\text { com sorriso, bem como a } \\
\text { grande maioria dos alunos } \\
\text { estão com sorriso no rosto. }\end{array}$ \\
\hline 11 & $\begin{array}{l}\text { Estagiário } \\
\text { Arnaldo }\end{array}$ & $\begin{array}{l}02 \min 01 \mathrm{~s} \\
\mathrm{a} \\
02 \min 11 \mathrm{~s}\end{array}$ & $\begin{array}{l}\text { Vamos lá... Oh!.... } \\
\text { Oh!... eu tenho um } \\
\text { balão... vocês viram, eu } \\
\text { enchi ele normalmente. } \\
\text { Só tem ar, né!? }\end{array}$ & $\begin{array}{l}\text { Estagiários estão segurando } \\
\text { um balão cada um. Arnaldo } \\
\text { continua à frente da classe, } \\
\text { movendo-se de um lado para } \\
\text { outro enquanto fala e Abel } \\
\text { sentado na carteira próxima à } \\
\text { Aluna } 3 \text {, que continua com as } \\
\text { mãos no rosto, cobrindo boca } \\
\text { e nariz. }\end{array}$ \\
\hline 12 & $\begin{array}{l}\text { Estagiário } \\
\text { Arnaldo }\end{array}$ & $\begin{array}{l}02 \min 12 \mathrm{~s} \\
\mathrm{a} \\
02 \min 22 \mathrm{~s}\end{array}$ & $\begin{array}{l}\text { Agora, a gente vai } \\
\text { aquecer o balão. Por } \\
\text { favor, Abel! }\end{array}$ & $\begin{array}{l}\text { Estagiário Abel liga o isqueiro } \\
\text { e aproxima do balão com ar, } \\
\text { fazendo-o estourar. Aluna } 3 \\
\text { que estava com as mãos no } \\
\text { rosto, sobre o nariz, leva os } \\
\text { dedos às orelhas, com as } \\
\text { mãos na lateral do rosto e vira } \\
\text { o rosto para o lado oposto ao } \\
\text { do estagiário Abel. Balão } \\
\text { estoura. Abel joga o isqueiro } \\
\text { para Arnaldo (que está } \\
\text { próximo à lousa e segurando } \\
\text { outro balão cheio com água) } \\
\text { Risos da classe. }\end{array}$ \\
\hline 13 & Aluna 3 & $02 \min 22 \mathrm{~s}$ & Brigada. & \\
\hline 14 & $\begin{array}{l}\text { Estagiário } \\
\text { Abel }\end{array}$ & $02 \min 22 \mathrm{~s}$ & De nada. & \\
\hline
\end{tabular}




\begin{tabular}{|c|c|c|c|c|}
\hline 15 & Aluna 3 & $\begin{array}{l}02 \min 23 s \\
\text { a } \\
02 \min 25 s\end{array}$ & Você é muito legal. & $\begin{array}{l}\text { Estende a mão esquerda } \\
\text { lateralmente e cumprimenta o } \\
\text { estagiário Abel. Classe está } \\
\text { em risos. }\end{array}$ \\
\hline 16 & $\begin{array}{l}\text { Estagiário } \\
\text { Abel }\end{array}$ & $\begin{array}{l}02 \min 26 s \\
\mathrm{a} \\
02 \min 27 \mathrm{~s}\end{array}$ & Satisfação! Precisar... & Risos \\
\hline 17 & $\begin{array}{l}\text { Estagiário } \\
\text { Arnaldo }\end{array}$ & $\begin{array}{l}02 \min 27 \mathrm{~s} \\
\mathrm{a} \\
02 \mathrm{~min} 39 \mathrm{~s}\end{array}$ & $\begin{array}{l}\text { Agora... Seguinte... } \\
\text { Menos de } 10 \text { segundos... } \\
5 \text { segundos, o balão } \\
\text { estourou, né!? Vocês } \\
\text { viram que eu tentei } \\
\text { colocar água aqui dentro, } \\
\text { né!? }\end{array}$ & $\begin{array}{l}\text { Segura outro balão com braço } \\
\text { estendido no alto. }\end{array}$ \\
\hline 18 & $\begin{array}{l}\text { Estagiário } \\
\text { Arnaldo }\end{array}$ & $\begin{array}{l}02 \min 39 s \\
\text { a } \\
02 \min 43 s\end{array}$ & $\begin{array}{l}\text { Acredita? ....Tem água } \\
\text { aqui, tá! }\end{array}$ & $\begin{array}{l}\text { Chacoalha o balão com as } \\
\text { duas mãos. Alguns alunos } \\
\text { fazem comentários } \\
\text { (inaudíveis) }\end{array}$ \\
\hline 19 & $\begin{array}{l}\text { Estagiário } \\
\text { Arnaldo }\end{array}$ & $02 \min 45 s$ & Beleza? & $\begin{array}{l}\text { Ergue o balão com água na } \\
\text { mão esquerda e com a mão } \\
\text { direita acende isqueiro e } \\
\text { aproxima a chama do balão. }\end{array}$ \\
\hline 20 & $\begin{array}{l}\text { Estagiário } \\
\text { Arnaldo }\end{array}$ & $\begin{array}{l}02 \min 45 s \\
\mathrm{a} \\
02 \mathrm{~min} 48 \mathrm{~s}\end{array}$ & $\begin{array}{l}\text { Agora eu vou colocar } \\
\text { fogo. }\end{array}$ & $\begin{array}{l}\text { Encosta a chama do isqueiro } \\
\text { no balão com água. }\end{array}$ \\
\hline 21 & Aluna 4 & 02min49s & Não vai estourar. & \multirow{5}{*}{$\begin{array}{l}\text { Estagiário Arnaldo continua } \\
\text { segurando chama do isqueiro } \\
\text { encostada ao balão. }\end{array}$} \\
\hline 22 & Aluna 5 & 02min50s & Legal! & \\
\hline 23 & Aluna 6 & $02 \mathrm{~min} 51 \mathrm{~s}$ & Tá frio! & \\
\hline 24 & $\begin{array}{l}\text { Estagiário } \\
\text { Arnaldo }\end{array}$ & 02min53s & Vamos lá! & \\
\hline 25 & $\begin{array}{l}\text { Estagiário } \\
\text { Arnaldo }\end{array}$ & $\begin{array}{l}02 \min 53 s \\
\text { a } \\
02 \min 55 s\end{array}$ & $\begin{array}{l}\text { Porque que ele não } \\
\text { estoura, pessoal? }\end{array}$ & \\
\hline 26 & $\begin{array}{l}\text { Estagiário } \\
\text { Arnaldo }\end{array}$ & $\begin{array}{l}02 \min 56 s \\
\text { a } \\
03 \min 21 s\end{array}$ & $\begin{array}{l}\text { [alguns comentários dos } \\
\text { alunos (inaudíveis)] }\end{array}$ & $\begin{array}{l}\text { Estagiário Arnaldo para, } \\
\text { acende uma vela e coloca a } \\
\text { vela sobre uma carteira. } \\
\text { Alguns alunos fazem alguns } \\
\text { comentários (inaudíveis) e } \\
\text { alguns risos. }\end{array}$ \\
\hline 27 & $\begin{array}{l}\text { Estagiário } \\
\text { Arnaldo }\end{array}$ & $\begin{array}{l}\text { 03min21s } \\
\mathrm{a} \\
03 \mathrm{~min} 28 \mathrm{~s}\end{array}$ & $\begin{array}{l}\text { Vai lá! ...Tá encostando? } \\
\text {...É, apaguei. (risos) }\end{array}$ & $\begin{array}{l}\text { Estagiário Arnaldo segura o } \\
\text { balão novamente junto à } \\
\text { chama da vela. Gira cabeça e } \\
\text { se abaixa para ver a chama da } \\
\text { vela sob o balão. Estagiário } \\
\text { Abel se dirige à carteira e } \\
\text { reacende a vela. }\end{array}$ \\
\hline 28 & Aluno 7 & $03 \min 29 \mathrm{~s}$ & Entendi, professor! & $\begin{array}{l}\text { Risos. E várias falas } \\
\text { misturadas de alunos. }\end{array}$ \\
\hline 29 & $\begin{array}{l}\text { Estagiário } \\
\text { Arnaldo }\end{array}$ & $\begin{array}{l}\text { 03min34s } \\
\mathrm{a} \\
03 \mathrm{~min} 35 \mathrm{~s}\end{array}$ & $\begin{array}{l}\text { Não! O importante é } \\
\text { entender. }\end{array}$ & \\
\hline
\end{tabular}




\begin{tabular}{|c|c|c|c|c|}
\hline 30 & $\begin{array}{l}\text { Estagiário } \\
\text { Arnaldo }\end{array}$ & $\begin{array}{l}\text { 03min35s } \\
\text { a } \\
03 \min 40 s\end{array}$ & $\begin{array}{l}\text { Pessoal! Apesar... vocês } \\
\text { viram o que aconteceu ... } \\
\text { (continuação inaudível) } \\
\text { Porque que o balão não } \\
\text { estourou? }\end{array}$ & $\begin{array}{l}\text { Se agacha e fica segurando o } \\
\text { balão próximo à chama da } \\
\text { vela. }\end{array}$ \\
\hline 31 & Aluno 8 & $\begin{array}{l}03 \min 41 \mathrm{~s} \\
\mathrm{a} \\
03 \min 45 \mathrm{~s}\end{array}$ & $\begin{array}{l}\text { Porque a água tá fria e } \\
\text { então... ela tá } \\
\text { absorvendo... calor. }\end{array}$ & \multirow{2}{*}{$\begin{array}{l}\text { Estagiário Arnaldo continua } \\
\text { segurando balão próximo à } \\
\text { chama e estagiário Abel está } \\
\text { sentado sobre a mesa do } \\
\text { professor. }\end{array}$} \\
\hline 32 & $\begin{array}{l}\text { Estagiário } \\
\text { Arnaldo }\end{array}$ & $\begin{array}{l}\text { 03min46s } \\
\text { a } \\
04 \min 05 s\end{array}$ & $\begin{array}{l}\text { Muito bem! Isso mesmo! } \\
\text { O calor está se } \\
\text { conduzindo mais pela } \\
\text { água que pelo ar. } \\
\text { Porque, por exemplo, } \\
\text { para esse balão estourar, } \\
\text { primeiro vai aquecer toda } \\
\text { essa água aqui dentro, } \\
\text { para depois aquecer o } \\
\text { ar... e assim... o látex } \\
\text { aqui, né, derreter, } \\
\text { explodir. }\end{array}$ & \\
\hline 33 & $\begin{array}{l}\text { Estagiário } \\
\text { Arnaldo }\end{array}$ & $\begin{array}{l}04 \min 05 s \\
a \\
04 \min 10 s\end{array}$ & $\begin{array}{l}\text { Entendeu? Entenderam } \\
\text { aqui, pessoal? Forma de } \\
\text { condução do calor? Bem } \\
\text { simples aqui. }\end{array}$ & $\begin{array}{l}\text { Estagiário Arnaldo está de pé } \\
\text { segurando balão com braço } \\
\text { estendido e sem haver } \\
\text { estourado. }\end{array}$ \\
\hline
\end{tabular}




\section{APÊNDICE D: TRANSCRIÇÃO DO EPISÓDIO 4}

\begin{tabular}{|c|c|c|c|c|}
\hline \multicolumn{5}{|c|}{ Episódio 4} \\
\hline Linha & Participante & Tempo & Processos verbais & Processos não verbais \\
\hline 1 & $\begin{array}{l}\text { Estagiária } \\
\text { Gisele }\end{array}$ & $\begin{array}{l}05 \min 03 s \\
a \\
05 \min 49 s\end{array}$ & & $\begin{array}{l}\text { Alguns alunos estão } \\
\text { conversando, trocando folhas, } \\
\text { enquanto estagiária explica. } \\
\text { Mas, em geral a classe está } \\
\text { olhando para estagiária e } \\
\text { prestando atenção na sua fala. } \\
\text { Estagiária está explicando sem } \\
\text { fazer perguntas sobre sua } \\
\text { explicação. Apenas no final } \\
\text { pergunta: Certo? Tudo bem? }\end{array}$ \\
\hline 2 & $\begin{array}{l}\text { Estagiária } \\
\text { Gisele }\end{array}$ & $\begin{array}{l}\text { 05min49s } \\
\text { a } \\
06 \min 02 s\end{array}$ & $\begin{array}{l}\text { Só que... A gente tá } \\
\text { falando aqui de } \\
\text { corrente, né. Tá } \\
\text { explicando o que é um } \\
\text { fio, como que você vai } \\
\text { utilizar. Só que esse fio } \\
\text { ele vai gerar uma coisa } \\
\text { que... Que também } \\
\text { tem o nome de elétrico. } \\
\text { Vocês sabem o que é? }\end{array}$ & $\begin{array}{l}\text { Estagiária dá alguns passos em } \\
\text { direção a mesa do professor e } \\
\text { olha rapidamente para suas } \\
\text { anotações. }\end{array}$ \\
\hline 3 & $\begin{array}{l}\text { Estagiária } \\
\text { Gisele }\end{array}$ & $\begin{array}{l}\text { 06min03s } \\
\text { a } \\
06 \text { min05s }\end{array}$ & $\begin{array}{l}\text { O campo. O campo } \\
\text { elétrico. }\end{array}$ & $\begin{array}{l}\text { Algum aluno parece ter falado } \\
\text { algo (inaudível) Estagiária } \\
\text { Gisele aponta para um aluno no } \\
\text { fundo da sala e acena 'sim' com } \\
\text { a cabeça. }\end{array}$ \\
\hline 4 & $\begin{array}{l}\text { Estagiária } \\
\text { Gisele }\end{array}$ & $\begin{array}{l}06 \min 06 \mathrm{~s} \\
\mathrm{a} \\
06 \mathrm{~min} 08 \mathrm{~s}\end{array}$ & $\begin{array}{l}\text { E aí, pra gente } \\
\text { entender isso melhor... }\end{array}$ & $\begin{array}{l}\text { Olha para o estagiário Maurício, } \\
\text { inclina a cabeça para o lado, } \\
\text { coça a cabeça e mexe no } \\
\text { cabelo. Estagiário Maurício } \\
\text { estava saindo de próximo da } \\
\text { lousa e vindo mais para frente, } \\
\text { mas para e retorna. }\end{array}$ \\
\hline 5 & $\begin{array}{l}\text { Estagiário } \\
\text { Maurício }\end{array}$ & $\begin{array}{l}06 \mathrm{~min} 08 \mathrm{~s} \\
\mathrm{a} \\
06 \mathrm{~min} 11 \mathrm{~s}\end{array}$ & $\begin{array}{l}\text { Vamos fazer diferente? } \\
\text { (fala muito baixa, pouco } \\
\text { audível) }\end{array}$ & $\begin{array}{l}\text { Mexe no pulso esquerdo com a } \\
\text { mão direita e fala algo } \\
\text { (inaudível) para estagiária } \\
\text { Gisele. }\end{array}$ \\
\hline 6 & $\begin{array}{l}\text { Estagiária } \\
\text { Gisele }\end{array}$ & $\begin{array}{l}06 \min 11 \mathrm{~s} \\
\mathrm{a} \\
06 \min 14 \mathrm{~s}\end{array}$ & $\begin{array}{l}\text { Não! Vamos imaginar o } \\
\text { fio, né. }\end{array}$ & $\begin{array}{l}\text { Estagiários estão olhando uma } \\
\text { para o outro enquanto falam. }\end{array}$ \\
\hline 7 & $\begin{array}{l}\text { Estagiária } \\
\text { Gisele }\end{array}$ & $\begin{array}{l}06 \min 14 \mathrm{~s} \\
\mathrm{a} \\
06 \mathrm{~min} 21 \mathrm{~s}\end{array}$ & $\begin{array}{l}\text { Tá encapado e aí a } \\
\text { corrente tá passando. } \\
\text { Se a gente desencapar } \\
\text { ele. Que que acontece? }\end{array}$ & $\begin{array}{l}\text { Estagiária Gisele se volta } \\
\text { novamente para classe e } \\
\text { estagiário Maurício volta para } \\
\text { junto da lousa. Inicialmente abre } \\
\text { a mão direita abaixo da cintura e }\end{array}$ \\
\hline
\end{tabular}




\begin{tabular}{|c|c|c|c|c|}
\hline & & & & $\begin{array}{l}\text { em seguida a apoia sobre o } \\
\text { aparador da lousa. }\end{array}$ \\
\hline 8 & $\begin{array}{l}\text { Estagiária } \\
\text { Gisele }\end{array}$ & & $\begin{array}{l}\text { Aqui tá passando vários } \\
\text { elétrons... }\end{array}$ & $\begin{array}{l}\text { Estagiária gesticula como se o } \\
\text { fio estivesse à sua frente. }\end{array}$ \\
\hline 9 & Aluna 1 & $06 \mathrm{~min} 21 \mathrm{~s}$ & Leva um choque. & \\
\hline 10 & $\begin{array}{l}\text { Estagiária } \\
\text { Gisele }\end{array}$ & $\begin{array}{l}\text { 06min22s } \\
\text { a } \\
06 \min 25 s\end{array}$ & $\begin{array}{l}\text { Tem que eu vou tomar } \\
\text { um choque. Mas, qual é } \\
\text { a ação que está } \\
\text { acontecendo? }\end{array}$ & Aponta para Aluna 1 \\
\hline 11 & Aluna 1 & 06min27s & Tá passando corrente. & \\
\hline 12 & $\begin{array}{l}\text { Estagiária } \\
\text { Gisele }\end{array}$ & 06min28s & Sim. Mas... & \\
\hline 13 & $\begin{array}{l}\text { Estagiário } \\
\text { Maurício }\end{array}$ & 06min29s & $\begin{array}{l}\text { Sim. Tá passando a } \\
\text { corrente elétrica... }\end{array}$ & $\begin{array}{l}\text { Estagiário Maurício retira mão } \\
\text { direita do aparador da lousa, } \\
\text { abre a mão, cruza as pernas, } \\
\text { encosta na lousa e apoia a mão } \\
\text { esquerda no aparador da lousa. }\end{array}$ \\
\hline 14 & $\begin{array}{l}\text { Estagiária } \\
\text { Gisele }\end{array}$ & $\begin{array}{l}\text { 06min30s } \\
\text { a } \\
06 \mathrm{~min} 42 \mathrm{~s}\end{array}$ & $\begin{array}{l}\text {...você tá fazendo o } \\
\text { quê? Porque, assim... } \\
\text { Tem o fio. Ele tá ali } \\
\text { desencapado. Mas a } \\
\text { corrente tá passando. } \\
\text { Só que ele não tá } \\
\text { encapado. Então ele tá } \\
\text { em contato com o ar. E } \\
\text { o ar, como vocês já } \\
\text { tinham dito } \\
\text { inicialmente, a gente } \\
\text { tem vários elétrons, né. }\end{array}$ & $\begin{array}{l}\text { Estagiário está apoiado na } \\
\text { lousa, com as pernas cruzadas } \\
\text { e com os braços abertos e as } \\
\text { duas mãos apoiadas no aparado } \\
\text { da lousa. }\end{array}$ \\
\hline 15 & $\begin{array}{l}\text { Estagiária } \\
\text { Gisele }\end{array}$ & $\begin{array}{l}\text { 06min42s } \\
\text { a } \\
06 \mathrm{~min} 47 \mathrm{~s}\end{array}$ & $\begin{array}{l}\text { A gente tem elétrons } \\
\text { aqui, só que a gente... } \\
\text { eles não dão choque } \\
\text { pra gente porquê... eles } \\
\text { não tão... (inaudível - } \\
\text { Aluna } 1 \text { começa a falar) }\end{array}$ & $\begin{array}{l}\text { Gesticula com as duas mãos } \\
\text { como se quisesse indicar } \\
\text { objetos no ar. }\end{array}$ \\
\hline 16 & Aluna 1 & 06min47s & Vai escapar... & \\
\hline 17 & $\begin{array}{l}\text { Estagiária } \\
\text { Gisele }\end{array}$ & 06min47s & Exato & \\
\hline 18 & Aluna 1 & $\begin{array}{l}06 \min 48 \mathrm{~s} \\
\mathrm{a} \\
06 \mathrm{~min} 49 \mathrm{~s}\end{array}$ & $\begin{array}{l}\text { Vai escapar... vais } \\
\text { escapar dessa corrente } \\
\text { e vai ... }\end{array}$ & \\
\hline 19 & $\begin{array}{l}\text { Estagiária } \\
\text { Gisele }\end{array}$ & $\begin{array}{l}\text { 06min50s } \\
\text { a } \\
07 \text { min } 00 \text { s }\end{array}$ & $\begin{array}{l}\text { Isso! Vai acontecer a } \\
\text { ionização do ar. A } \\
\text { ionização dos } \\
\text { elétrons... que estão } \\
\text { soltos. No ambiente. No } \\
\text { ar em si. }\end{array}$ & $\begin{array}{l}\text { Balança as duas mãos na altura } \\
\text { do ombro para os lados, } \\
\text { initerruptamente (até ir à mesa). } \\
\text { Ao final, se aproxima da mesa } \\
\text { do professor e olha suas } \\
\text { anotações em um papel, abaixa } \\
\text { a cabeça para ler e o Estagiário } \\
\text { Maurício dá sequência na fala. }\end{array}$ \\
\hline 20 & $\begin{array}{l}\text { Estagiário } \\
\text { Maurício }\end{array}$ & $\begin{array}{l}07 \min 01 \mathrm{~s} \\
\mathrm{a} \\
07 \min 15 \mathrm{~s}\end{array}$ & $\begin{array}{l}\text { Exatamente! } \\
\text { Basicamente, o que } \\
\text { acontece, gente, } \\
\text { quando você tem a } \\
\text { corrente elétrica }\end{array}$ & $\begin{array}{l}\text { Estagiário Maurício retira as } \\
\text { mãos do aparador da lousa, } \\
\text { desencosta da lousa e inicia fala } \\
\text { gesticulando com as duas mãos }\end{array}$ \\
\hline
\end{tabular}




\begin{tabular}{|c|c|c|c|c|}
\hline & & & $\begin{array}{l}\text { passando pelo fio, o ar } \\
\text { que está em volta } \\
\text { daquele fio, naquela } \\
\text { região, próxima ao fio, } \\
\text { ele começa a receber } \\
\text { essas... pequenas } \\
\text { cargas... essas } \\
\text { pequenos elétrons. Que } \\
\text { estão escapando. }\end{array}$ & $\begin{array}{l}\text { como representasse o fio e o } \\
\text { campo a sua volta. } \\
\text { Estagiário Gisele vira-se de } \\
\text { costas para a classe e começa } \\
\text { traçar na lousa uma linha e }\end{array}$ \\
\hline 21 & $\begin{array}{l}\text { Estagiário } \\
\text { Maurício }\end{array}$ & $\begin{array}{l}07 \min 16 s \\
a \\
07 \min 25 s\end{array}$ & $\begin{array}{l}\text { Então, essa região em } \\
\text { volta. Que a gente fala } \\
\text { que é ionizada... Que } \\
\text { gera esse fenômeno } \\
\text { que a gente chama } \\
\text { de... campo elétrico. }\end{array}$ & $\begin{array}{l}\text { Gesticula bastante com as duas } \\
\text { mãos como mostrando o fio e } \\
\text { seu entorno. }\end{array}$ \\
\hline 22 & $\begin{array}{l}\text { Estagiário } \\
\text { Maurício }\end{array}$ & $\begin{array}{l}07 \min 26 s \\
\text { a } \\
07 \min 32 s\end{array}$ & $\begin{array}{l}\text { Então, quanto mais } \\
\text { você se aproxima do } \\
\text { fio... maior é a chance } \\
\text { de você entrar em } \\
\text { contato com esse } \\
\text { campo elétrico. }\end{array}$ & $\begin{array}{l}\text { Aponta na lousa a região } \\
\text { próxima da linha desenhada } \\
\text { pela estagiária Gisele e se } \\
\text { afasta abrindo as duas mãos à } \\
\text { meia altura e com as palmas } \\
\text { para cima. }\end{array}$ \\
\hline 23 & $\begin{array}{l}\text { Estagiário } \\
\text { Maurício }\end{array}$ & $\begin{array}{l}07 \min 32 s \\
\text { a } \\
07 \min 35 s\end{array}$ & $\begin{array}{l}\text { Aí eu pergunto: um fio } \\
\text { de tomada (inaudível) } \\
\text { um campo elétrico } \\
\text { (inaudível)? }\end{array}$ & $\begin{array}{l}\text { Movimenta um pouco as mãos } \\
\text { mas as mantém basicamente } \\
\text { na posição abertas à meia } \\
\text { altura com as palmas voltadas } \\
\text { para cima. }\end{array}$ \\
\hline 24 & $\begin{array}{l}\text { Aluna (não } \\
\text { identificada) }\end{array}$ & $07 \min 35 s$ & Hãã? & $\begin{array}{l}\text { Fala da aluna foi em tom de } \\
\text { espanto. }\end{array}$ \\
\hline 25 & Aluno 2 & $07 \mathrm{~min} 37 \mathrm{~s}$ & Não. & \\
\hline 26 & $\begin{array}{l}\text { Estagiário } \\
\text { Maurício }\end{array}$ & $07 \mathrm{~min} 38 \mathrm{~s}$ & E o fio do poste? & \\
\hline 27 & Aluna 1 & 07min39s & É outro papo. & \\
\hline 28 & Aluno 2 & 07min40s & Deve ter. & \\
\hline 29 & Aluno 2 & $\begin{array}{l}\text { 07min40s } \\
\mathrm{a} \\
07 \mathrm{~min} 42 \mathrm{~s}\end{array}$ & Se for o de cima, tem. & $\begin{array}{l}\text { Ergue braço esquerdo com a } \\
\text { dedos na horizontal. Ri no final. }\end{array}$ \\
\hline 30 & $\begin{array}{l}\text { Estagiária } \\
\text { Gisele }\end{array}$ & $\begin{array}{l}07 \min 43 s \\
\text { a } \\
07 \min 44 s\end{array}$ & $\hat{E} !$ & $\begin{array}{l}\text { Balança a cabeça como } \\
\text { representando ‘sim', enquanto } \\
\text { coça o pulso direito, enquanto } \\
\text { segura giz na mão direita. }\end{array}$ \\
\hline 31 & $\begin{array}{l}\text { Estagiária } \\
\text { Gisele }\end{array}$ & $\begin{array}{l}\text { 07min44s } \\
\mathrm{a} \\
07 \min 46 \mathrm{~s}\end{array}$ & $\begin{array}{l}\text { A gente vai entrar } \\
\text { nessas ... }\end{array}$ & $\begin{array}{l}\text { Coça o pulso direito enquanto } \\
\text { segura o giz com a mão direita. }\end{array}$ \\
\hline 32 & $\begin{array}{l}\text { Estagiário } \\
\text { Maurício }\end{array}$ & $\begin{array}{l}07 \min 46 s \\
\text { a } \\
07 \min 53 s\end{array}$ & $\begin{array}{l}\text { Exatamente! E o que } \\
\text { difere o fio do poste e o } \\
\text { fio da nossa tomada? } \\
\text { Pra você pensar que } \\
\text { tem uma diferença } \\
\text { nesse... }\end{array}$ & \\
\hline 33 & Aluno 2 & $07 \min 53 \mathrm{~s}$ & A tensão. & \\
\hline 34 & Aluna 1 & $07 \min 53 \mathrm{~s}$ & A tensão. & \\
\hline
\end{tabular}




\begin{tabular}{|c|c|c|c|c|}
\hline 35 & & $\begin{array}{l}07 \min 54 s \\
\text { a } \\
07 \min 58 \mathrm{~s}\end{array}$ & $\begin{array}{l}\text { A tensão é diferente, } \\
\text { né. A corrente também } \\
\text { é diferente. }\end{array}$ & $\begin{array}{l}\text { Toca os dedos da mão esquerda } \\
\text { com o indicador da mão direita } \\
\text { como se quisesse contar. }\end{array}$ \\
\hline 36 & Aluno 1 & 07min58s & É maior. & \\
\hline 37 & $\begin{array}{l}\text { Estagiário } \\
\text { Maurício }\end{array}$ & $\begin{array}{l}\text { 07min58s } \\
\text { a } \\
08 \min 09 s\end{array}$ & $\begin{array}{l}\text { Você tem uma } \\
\text { quantidade maior de } \\
\text { energia, né... corrente } \\
\text { muito maior. E a tensão } \\
\text { com... com.... um } \\
\text { empuxo, com uma... } \\
\text { um (inaudível) muito } \\
\text { mais... o ar que está } \\
\text { (inaudível) pra poder } \\
\text { chegar na casa da } \\
\text { gente, né. }\end{array}$ & $\begin{array}{l}\text { Gesticula com as mãos como se } \\
\text { quisesse indicar os fios. E } \\
\text { depois a mão esquerda fechada } \\
\text { à meia altura e a mão direita } \\
\text { saindo várias vezes do contato } \\
\text { com a mão esquerda. } \\
\text { Estagiária Gisele está enchendo } \\
\text { um balão de festa com ar. }\end{array}$ \\
\hline 38 & $\begin{array}{l}\text { Estagiário } \\
\text { Maurício }\end{array}$ & $\begin{array}{l}\text { 08min10s } \\
a \\
08 \min 15 s\end{array}$ & $\begin{array}{l}\text { E... Bom. (inaudível) é } \\
\text { aquilo que eu falei } \\
\text { (inaudível) uma } \\
\text { experiência pra mostrar } \\
\text { para vocês que que é } \\
\text { essa interação do } \\
\text { campo elétrico. }\end{array}$ & $\begin{array}{l}\text { Balão escapa das mãos da } \\
\text { estagiária aos 8min15s, fazendo } \\
\text { voltas em ziguezague no ar. } \\
\text { (risos) }\end{array}$ \\
\hline
\end{tabular}




\section{APÊNDICE E: TRANSCRIÇÃO DO EPISÓDIO 5}

\begin{tabular}{|c|c|c|c|c|}
\hline \multicolumn{5}{|c|}{ Episódio 5} \\
\hline Linha & Participante & Tempo & Processos verbais & Processos não verbais \\
\hline 1 & \multicolumn{4}{|c|}{$\begin{array}{l}\text { Até o instante 6min11s estagiários estavam abordando a situação do chuveiro elétrico, } \\
\text { conduzida pela fala quase exclusiva da estagiária Gisele, com aspectos relacionados ao } \\
\text { chuveiro que trouxeram. Ao finalizar sua fala, estagiária Gisele troca olhares com } \\
\text { estaqiário Maurício, como passando a palavra um para o outro. }\end{array}$} \\
\hline 2 & $\begin{array}{l}\text { Estagiário } \\
\text { Maurício }\end{array}$ & $\begin{array}{l}6 \min 12 s \text { a } \\
6 \min 34 s\end{array}$ & $\begin{array}{l}\text { Tem, tem uma coisa que } \\
\text { acontece, que é bem } \\
\text { interessante, que é uma } \\
\text { parte dessa [inaudível] hoje } \\
\text { em dia. Eletricidade e } \\
\text { magnetismo são duas } \\
\text { coisas que andam muito } \\
\text { juntas, assim. Então, o que a } \\
\text { gente fez aqui foi: passar } \\
\text { uma corrente elétrica, por } \\
\text { um equipamento, que gerou } \\
\text { um campo elétrico, esse } \\
\text { campo gerou um campo } \\
\text { magnético. E, combinado } \\
\text { com o imã, gerou } \\
\text { movimento. }\end{array}$ & $\begin{array}{l}\text { Estagiário Maurício está } \\
\text { encostado na lousa, com } \\
\text { pernas cruzadas, com as } \\
\text { mãos encostada à lateral } \\
\text { da perna e ergue os dedos } \\
\text { da mão direita. Em seguida, } \\
\text { move as duas mãos uma } \\
\text { próxima à outra, à altura do } \\
\text { peito, como mostrando } \\
\text { engrenagens. Estagiária } \\
\text { Gisele está olhando papel } \\
\text { com suas anotações. }\end{array}$ \\
\hline 3 & $\begin{array}{l}\text { Estagiário } \\
\text { Maurício }\end{array}$ & $\begin{array}{l}6 \min 34 s \text { a } \\
7 \mathrm{~min} 02 \mathrm{~s}\end{array}$ & $\begin{array}{l}\text { Eu fiz o movimento... Né? Eu } \\
\text { coloquei corrente elétrica no } \\
\text { imã. Transformei em } \\
\text { movimento. O princípio da } \\
\text { usina hidrelétrica, quando a } \\
\text { gente gera eletricidade, né. } \\
\text { Não só na usina hidrelétrica, } \\
\text { mas qualquer usina que usa } \\
\text { o gerador né, que tem o } \\
\text { princípio do gerador, é um } \\
\text { princípio muito parecido. } \\
\text { Muito pare... Tá muito } \\
\text { conectado com ele. Só que } \\
\text { lá eu não tenho energia } \\
\text { elétrica. Lá, lá eu vou } \\
\text { produzir a energia. Então, } \\
\text { esse é o princípio que a } \\
\text { gente quer mostrar para } \\
\text { vocês. }\end{array}$ & $\begin{array}{l}\text { Estagiário Maurício } \\
\text { aumenta os movimentos } \\
\text { com as mãos, como se } \\
\text { mostrasse movimentos do } \\
\text { motor de liquidificador e/ou } \\
\text { engrenagens. Troca vários } \\
\text { olhares com estagiária } \\
\text { Gisele enquanto } \\
\text { movimenta as mãos e olha } \\
\text { para os alunos. } \\
\text { Termina interrompido pela } \\
\text { estagiária Gisele que está } \\
\text { de costas para a sala, } \\
\text { escrevendo na lousa. } \\
\text { Estagiário Maurício para } \\
\text { bruscamente a fala com as } \\
\text { mãos à frente e com os } \\
\text { dedos entrecruzados. }\end{array}$ \\
\hline 4 & $\begin{array}{l}\text { Estagiária } \\
\text { Gisele }\end{array}$ & $\begin{array}{l}7 \min 02 s \text { a } \\
7 \text { min03s }\end{array}$ & E assim... Desculpa! & $\begin{array}{l}\text { Estagiária fala de costas } \\
\text { para classe e escrevendo } \\
\text { na lousa. Ao final. Vira-se } \\
\text { rapidamente para a classe. }\end{array}$ \\
\hline 5 & $\begin{array}{l}\text { Estagiária } \\
\text { Gisele }\end{array}$ & $\begin{array}{l}7 \min 04 s \text { a } \\
7 \min 22 s\end{array}$ & $\begin{array}{l}\text { O legal é que... O que a } \\
\text { gente engloba, né? A física, } \\
\text { ela não costuma ser uma } \\
\text { coisa isolada. Tipo, eu vou } \\
\text { explicar isso, pronto, }\end{array}$ & $\begin{array}{l}\text { Estagiária se vira } \\
\text { rapidamente para classe e } \\
\text { fala fazendo vários } \\
\text { movimentos com as mãos. }\end{array}$ \\
\hline
\end{tabular}




\begin{tabular}{|c|c|c|c|c|}
\hline & & & $\begin{array}{l}\text { acabou. Não. Ela começa } \\
\text { juntar todos os conceitos e } \\
\text { aí a gente consegue } \\
\text { desenvolver n coisas. Aqui, } \\
\text { o legal é que a gente } \\
\text { começou com uma energia } \\
\text { elétrica e transformou numa } \\
\text { energia o quê? }\end{array}$ & \\
\hline 6 & $\begin{array}{l}\text { Estagiária } \\
\text { Gisele }\end{array}$ & $\begin{array}{l}7 \min 23 s \text { a } \\
7 \min 25 s\end{array}$ & [Silêncio] & \\
\hline 7 & $\begin{array}{l}\text { Estagiário } \\
\text { Maurício }\end{array}$ & $\begin{array}{l}7 \min 25 s \text { a } \\
7 \min 26 s\end{array}$ & $\begin{array}{l}\text { O que é energia do } \\
\text { movimento, gente? }\end{array}$ & $\begin{array}{l}\text { Estagiário está encostado } \\
\text { na lousa e faz movimento } \\
\text { de uma mão girando em } \\
\text { tordo da outra, à frente do } \\
\text { corpo. } \\
\text { Alunos estão bem atentos } \\
\text { aos estagiários e sem } \\
\text { conversas entre eles. } \\
\text { Maioria com mão no queixo } \\
\text { ou no rosto e olhares bem } \\
\text { atentos. }\end{array}$ \\
\hline 8 & $\begin{array}{l}\text { Aluno (não } \\
\text { identificado) }\end{array}$ & $\begin{array}{l}7 \min 25 s \text { a } \\
7 \min 26 s\end{array}$ & [não audível] & $\begin{array}{l}\text { Estagiária Gisele balança a } \\
\text { cabeça para cima e para } \\
\text { baixo, olhando na direção } \\
\text { de um grupo de alunos, em } \\
\text { sinal de concordância com } \\
\text { fala do aluno. } \\
\text { Alunos estão bem atentos } \\
\text { aos estagiários e sem } \\
\text { conversas entre eles. } \\
\text { Maioria com mão no queixo } \\
\text { ou no rosto e olhares bem } \\
\text { atentos. }\end{array}$ \\
\hline 9 & $\begin{array}{l}\text { Estagiária } \\
\text { Gisele }\end{array}$ & $\begin{array}{l}7 \min 27 s \text { a } \\
7 \min 34 s\end{array}$ & $\begin{array}{l}\text { Uma energia cinética, né. } \\
\text { Então, aqui nesse caso, a } \\
\text { gente tá [não audível] uma } \\
\text { energia cinética. Mas, o que } \\
\text { que o chuveiro faz? }\end{array}$ & $\begin{array}{l}\text { Estagiária está à frente da } \\
\text { mesa do professor e às } \\
\text { vezes olha rapidamente } \\
\text { para suas anotações. Ao } \\
\text { final da fala, coloca a mão } \\
\text { direita no encosto da } \\
\text { carteira e, com o braço } \\
\text { direito esticado, deixa o } \\
\text { corpo mais caído para a } \\
\text { direita. } \\
\text { Alunos estão bem atentos } \\
\text { aos estagiários e sem } \\
\text { conversas entre eles. } \\
\text { Maioria com mão no queixo } \\
\text { ou no rosto e olhares bem } \\
\text { atentos. }\end{array}$ \\
\hline 10 & Aluna 1 & $\begin{array}{l}7 \min 34 s \text { a } \\
7 \min 36 s\end{array}$ & Energia. & $\begin{array}{l}\text { Estagiária Gisele olha na } \\
\text { direção da Aluna } 1 \text { e } \\
\text { balança a cabeça para } \\
\text { cima e para baixo, em sinal } \\
\text { de aprovação. } \\
\text { Alunos estão bem atentos } \\
\text { aos estagiários e sem } \\
\text { conversas entre eles. }\end{array}$ \\
\hline
\end{tabular}




\begin{tabular}{|c|c|c|c|c|}
\hline & & & & $\begin{array}{l}\text { Maioria com mão no queixo } \\
\text { ou no rosto e olhares bem } \\
\text { atentos. }\end{array}$ \\
\hline 11 & Aluno 2 & $\begin{array}{l}7 \min 35 s \text { a } \\
7 \min 36 s\end{array}$ & Aquece água. & $\begin{array}{l}\text { Alunos estão bem atentos } \\
\text { aos estagiários e sem } \\
\text { conversas entre eles. } \\
\text { Maioria com mão no queixo } \\
\text { ou no rosto e olhares bem } \\
\text { atentos. }\end{array}$ \\
\hline 12 & $\begin{array}{l}\text { Estagiário } \\
\text { Maurício }\end{array}$ & $7 \mathrm{~min} 37 \mathrm{~s}$ & $\begin{array}{lll}\text { Aquece água. Então } & 0 \\
\text { chuveiro } & \text { recebe } & \text { a } \\
\text { eletricidade... } & & \end{array}$ & $\begin{array}{l}\text { Alunos estão bem atentos } \\
\text { aos estagiários e sem } \\
\text { conversas entre eles. } \\
\text { Maioria com mão no queixo } \\
\text { ou no rosto e olhares bem } \\
\text { atentos. }\end{array}$ \\
\hline 13 & $\begin{array}{l}\text { Estagiária } \\
\text { Gisele }\end{array}$ & $\begin{array}{l}7 \min 37 s \text { a } \\
7 \min 40 s\end{array}$ & $\begin{array}{l}\text { Então, [inaudível, fala } \\
\text { simultânea com } \\
\text { Maurício] uma } \\
\text { cinética, né. }\end{array}$ & $\begin{array}{l}\text { Estagiária faz um giro com } \\
\text { a mão direita na lateral do } \\
\text { corpo, à altura do ombro e } \\
\text { com a mão esquerda } \\
\text { aponta para o estagiário } \\
\text { Maurício. } \\
\text { Alunos estão bem atentos } \\
\text { aos estagiários e sem } \\
\text { conversas entre eles. } \\
\text { Maioria com mão no queixo } \\
\text { ou no rosto e olhares bem } \\
\text { atentos. }\end{array}$ \\
\hline 14 & $\begin{array}{l}\text { Estagiário } \\
\text { Maurício }\end{array}$ & $\begin{array}{l}7 \min 37 s \text { a } \\
7 \min 39 s\end{array}$ & $\begin{array}{lr}\begin{array}{l}\text { Aquece água. } \\
\text { chuveiro } \\
\text { eletricidade... }\end{array} & \begin{array}{r}\text { Então, } 0 \\
\text { recebe }\end{array} \\
\end{array}$ & $\begin{array}{l}\text { Estagiário para de falar e } \\
\text { olha para estagiária Gisele. }\end{array}$ \\
\hline 15 & $\begin{array}{l}\text { Aluna (não } \\
\text { identificada) }\end{array}$ & $7 \mathrm{~min} 40 \mathrm{~s}$ & Nossa! & $\begin{array}{l}\text { Não foi possível identificar } \\
\text { se fala se referia a aula ou }\end{array}$ \\
\hline 16 & $\begin{array}{l}\text { Aluno (não } \\
\text { identificado) }\end{array}$ & $7 \mathrm{~min} 41 \mathrm{~s}$ & Já era. & a outro assunto. \\
\hline 17 & $\begin{array}{l}\text { Estagiário } \\
\text { Maurício }\end{array}$ & $\begin{array}{l}7 \min 41 s \text { a } \\
7 \min 42 s\end{array}$ & $\begin{array}{l}\text { Não tá gerando movimento, } \\
\text { né!? }\end{array}$ & $\begin{array}{l}\text { Estagiário está encostado } \\
\text { na lousa e faz alguns } \\
\text { movimentos com as mãos } \\
\text { enquanto fala. }\end{array}$ \\
\hline 18 & Aluno 2 & $7 \mathrm{~min} 42 \mathrm{~s}$ & Tá gerando calor. & \\
\hline 19 & $\begin{array}{l}\text { Estagiário } \\
\text { Maurício }\end{array}$ & $7 \min 43 s$ & Tá gerando calor. & $\begin{array}{l}\text { Estagiário balança a } \\
\text { cabeça para cima e para } \\
\text { baixo e aponta para Aluno } \\
2 \text {. }\end{array}$ \\
\hline 20 & $\begin{array}{l}\text { Estagiário } \\
\text { Maurício }\end{array}$ & $\begin{array}{l}7 \min 44 s \text { a } \\
7 \min 46 s\end{array}$ & $\begin{array}{l}\text { Então, a } \quad \text { gente rá tá } \\
\text { transformando } \\
\text { elétrica em energia... }\end{array}$ & \\
\hline 21 & Aluno 2 & $\begin{array}{l}7 \min 46 s \text { a } \\
7 \min 48 s\end{array}$ & Humm. & \\
\hline 22 & $\begin{array}{l}\text { Estagiário } \\
\text { Maurício }\end{array}$ & $\begin{array}{l}7 \min 48 s \text { a } \\
7 \min 50 s\end{array}$ & $\begin{array}{lll}\text { Térmica, } & \text { né! } & \text { Calor, } \\
\text { energia... }\end{array}$ & $\begin{array}{l}\text { Estagiários se olham, dão } \\
\text { risada curta juntamente } \\
\text { com Aluno 2. Estagiária } \\
\text { Gisele balança a cabeça } \\
\text { para cima e para baixo. }\end{array}$ \\
\hline 23 & $\begin{array}{l}\text { Estagiário } \\
\text { Maurício }\end{array}$ & $\begin{array}{l}7 \min 51 \mathrm{~s} a \\
8 \min 17 \mathrm{~s}\end{array}$ & $\begin{array}{l}\text { Então, embora os aparelhos } \\
\text { funcionem de maneiras } \\
\text { diferentes, todos eles }\end{array}$ & $\begin{array}{l}\text { Estagiário faz gestos com } \\
\text { as mãos como passando }\end{array}$ \\
\hline
\end{tabular}




\begin{tabular}{|c|c|c|c|c|}
\hline & & & $\begin{array}{l}\text { recebem eletricidade e o que } \\
\text { ele faz na verdade é } \\
\text { transformar aquela energia } \\
\text { elétrica na no tipo de energia } \\
\text { que me interessa. Então, } \\
\text { para o liquidificador... se } \\
\text { você pensar em qualquer } \\
\text { outro aparelho que usa } \\
\text { motor elétrico eu tô } \\
\text { interessado em movimento. } \\
\text { Se eu tô pensando por } \\
\text { exemplo no chuveiro, no } \\
\text { ferro de passar roupa, } \\
\text { chapinha de cabelo, } \\
\text { secador.. }\end{array}$ & $\begin{array}{l}\text { algo de uma mão para a } \\
\text { outra. } \\
\text { Estagiário move braço } \\
\text { direito para cima e para } \\
\text { baixo várias vezes, como } \\
\text { se enumerasse seus } \\
\text { exemplos. }\end{array}$ \\
\hline 24 & $\begin{array}{l}\text { Estagiária } \\
\text { Gisele }\end{array}$ & $8 \min 16 s$ & Forno. & $\begin{array}{l}\text { Estagiária está com mão } \\
\text { direita apoiada no encosto } \\
\text { da cadeira da mesa do } \\
\text { professor e com corpo } \\
\text { caído para direita, } \\
\text { balançando a cabeça para } \\
\text { cima e para baixo enquanto } \\
\text { o estagiário Maurício fala. }\end{array}$ \\
\hline 25 & Aluna 2 & $8 \min 18 s$ & Micro-ondas. & \\
\hline 26 & $\begin{array}{l}\text { Estagiário } \\
\text { Maurício }\end{array}$ & $8 \mathrm{~min} 20 \mathrm{~s}$ & $\begin{array}{l}\text { Forno. Eu tô transformando } \\
\text { em? Calor. }\end{array}$ & $\begin{array}{l}\text { Alguns alunos estão } \\
\text { falando ao mesmo tempo, } \\
\text { uma aluna fala direcionada } \\
\text { à estagiária Gisele. }\end{array}$ \\
\hline 27 & $\begin{array}{l}\text { Estagiária } \\
\text { Gisele }\end{array}$ & $\begin{array}{l}8 \min 18 \mathrm{~s} a \\
8 \min 22 \mathrm{~s}\end{array}$ & Não. Eu não sei. É. Mas, é... & $\begin{array}{l}\text { Uma aluna fala algo } \\
\text { (inaudível) para a } \\
\text { estagiária, inicialmente ela } \\
\text { balança a cabeça para os } \\
\text { lados (sinal de não) em } \\
\text { seguida balança a cabeça } \\
\text { para cima e para baixo. }\end{array}$ \\
\hline 28 & $\begin{array}{l}\text { Estagiária } \\
\text { Gisele }\end{array}$ & $\begin{array}{l}8 \min 22 s \text { a } \\
8 \min 26 s\end{array}$ & $\begin{array}{l}\text { Então. É que o micro-ondas } \\
\text { é uma coisa... né... muito } \\
\text { diferenciada. }\end{array}$ & $\begin{array}{l}\text { (Estagiária Gisele, que } \\
\text { estava se dirigindo a uma } \\
\text { aluna, passa a dirigir a } \\
\text { palavra para a classe.) } \\
\text { Estagiária coça várias } \\
\text { vezes o queixo enquanto } \\
\text { fala. }\end{array}$ \\
\hline 29 & $\begin{array}{l}\text { Estagiária } \\
\text { Gisele }\end{array}$ & $\begin{array}{l}8 \min 26 s \text { a } \\
8 \min 40 s\end{array}$ & $\begin{array}{l}\text { Porque a gente vai ter que } \\
\text { pegar a energia elétrica } \\
\text { entrando, a gente vai ter a } \\
\text { energia... mecânica pra } \\
\text { girar, ali. A gente vai ter, de } \\
\text { fato... as micro-ondas, que } \\
\text { são geradas ali. Então, ali é } \\
\text { o campo magnético. }\end{array}$ & $\begin{array}{l}\text { Vai tocando os dedos da } \\
\text { mão esquerda com o } \\
\text { indicador da direita (como } \\
\text { enumerando), intercalando } \\
\text { com outros gestos como } \\
\text { girar a mão direita em } \\
\text { círculos na horizontal. }\end{array}$ \\
\hline 30 & $\begin{array}{l}\text { Aluna (não } \\
\text { identificada) }\end{array}$ & $\begin{array}{l}8 \min 39 s \text { a } \\
8 \min 41 s\end{array}$ & Pa... po... po... que você. & $\begin{array}{l}\text { Aluna aparentemente iria } \\
\text { fazer uma pergunta e } \\
\text { gaguejou. }\end{array}$ \\
\hline 31 & $\begin{array}{l}\text { Estagiária } \\
\text { Gisele }\end{array}$ & $\begin{array}{l}8 \min 40 s \text { a } \\
8 \min 42 s\end{array}$ & Né. & $\begin{array}{l}\text { Estagiária dá passos para } \\
\text { trás e para o lado, olha para } \\
\text { o estagiário Maurício. }\end{array}$ \\
\hline
\end{tabular}




\begin{tabular}{|c|c|c|c|c|}
\hline 32 & $\begin{array}{l}\text { Estagiária } \\
\text { Gisele }\end{array}$ & $\begin{array}{l}8 \min 42 s \text { a } \\
8 \min 45 s\end{array}$ & $\begin{array}{l}\text { Porque o campo elétrico, a } \\
\text { gente só consegue ionizar. }\end{array}$ & $\begin{array}{l}\text { Aponta com a mão } \\
\text { esquerda na direção do } \\
\text { estagiário Maurício. }\end{array}$ \\
\hline 33 & $\begin{array}{l}\text { Estagiária } \\
\text { Gisele }\end{array}$ & $\begin{array}{l}8 \min 45 s \text { a } \\
9 \min 01\end{array}$ & $\begin{array}{l}\text { Pra esquentar, pra mover a } \\
\text { molécula, a gente vai } \\
\text { precisar do campo } \\
\text { magnético. E aí que o micro- } \\
\text { ondas vai gerar de fato as } \\
\text { micro-ondas. Então, as } \\
\text { ondas magnéticas que estão } \\
\text { passando. Ondas } \\
\text { magnéticas, por exemplo, } \\
\text { são responsáveis pelo wifi, } \\
\text { pelo sinal do celular, rádio. }\end{array}$ & \\
\hline 34 & Aluna 2 & $\begin{array}{l}8 \min 59 \mathrm{~s} a \\
9 \min 00 \mathrm{~s}\end{array}$ & Adoro ouvir radinho de pilha. & \\
\hline 35 & $\begin{array}{l}\text { Estagiária } \\
\text { Gisele }\end{array}$ & $\begin{array}{l}9 \min 01 \mathrm{~s} a \\
9 \min 27 \mathrm{~s}\end{array}$ & $\begin{array}{l}\text { Então, um conceito, simples, } \\
\text { que vem aqui, ó, de uma, da } \\
\text { primeira lei de Ohm, que } \\
\text { seria, aqui nesse caso, é } \\
\text { elétrica. Ele vai chegar em } \\
\text { eletromagnetismo, que onde } \\
\text { a gente conseguiu chegar na } \\
\text { sociedade atual. Que a } \\
\text { gente conseguiu ter: rádio, } \\
\text { sinal de televisão, sinal de } \\
\text { celular, e... wifi. Que eu } \\
\text { acho que é uma coisa assim } \\
\text { magnífica. A gente não tá } \\
\text { vendo, e tá conectado por } \\
\text { uma coisa que tá ali na toma } \\
\text { e tá ionizando o ar, ele tá na } \\
\text { nossa casa inteira. }\end{array}$ & $\begin{array}{l}\text { Estagiária aponta para a } \\
\text { lousa, junto a expressão } \\
\text { matemática da primeira lei } \\
\text { de Ohm. } \\
\text { Estagiária faz vários gestos } \\
\text { com movimentos circulares } \\
\text { com as mãos. }\end{array}$ \\
\hline 36 & Aluna 3 & $\begin{array}{l}9 \min 26 s \text { a } \\
9 \min 30 s\end{array}$ & $\begin{array}{l}\text { O, o ... o wireless também } \\
\text { é passado por energia? }\end{array}$ & \\
\hline 37 & $\begin{array}{l}\text { Estagiária } \\
\text { Gisele }\end{array}$ & $\begin{array}{l}9 \min 30 \mathrm{~s} a \\
10 \min 00 \mathrm{~s}\end{array}$ & $\begin{array}{l}\text { Sim. Então. } \bar{E} \text { que na } \\
\text { verdade ali, você tá ligando } \\
\text { ele na tomada e o... o cabo } \\
\text { de... com a internet, né. Com } \\
\text { a.. com os dados. Vamos } \\
\text { assim dizer. E aí ele vai } \\
\text { pegar essas dados e vai } \\
\text { emitir. Ele transforma em } \\
\text { ondas magnéticas. E } \\
\text { transmite. A luz, por } \\
\text { exemplo é uma onda... ela ... } \\
\text { o legal da luz. Que é quando } \\
\text { a gente começa a descobrir } \\
\text { as ondas magnéticas. É que } \\
\text { ela é uma onda elétrica e } \\
\text { magnética ao mesmo } \\
\text { tempo. }\end{array}$ & \\
\hline
\end{tabular}




\section{APÊNDICE F: TRANSCRIÇÃO DO EPISÓDIO 6}

\begin{tabular}{|c|c|c|c|c|}
\hline \multicolumn{5}{|c|}{ Episódio 6} \\
\hline Linha & Participante & Tempo & Processos verbais & Processos não verbais \\
\hline 1 & $\begin{array}{l}\text { Estagiário } \\
\text { Fernando }\end{array}$ & $\begin{array}{l}\text { Omin00s } \\
\text { a } \\
3 \min 07 \mathrm{~s}\end{array}$ & $\begin{array}{l}\text { (Estagiário Fernando } \\
\text { explicou Princípio da Troca } \\
\text { de Calor, enfatizando que } \\
\text { o calor vai do corpo de } \\
\text { temperatura mais alta para } \\
\text { o mais baixa, nunca o } \\
\text { contrário, utiliza exemplo } \\
\text { do gelo em um copo de } \\
\text { refrigerante) }\end{array}$ & $\begin{array}{l}\text { Estagiária Adelaide está } \\
\text { escrevendo na lousa } \\
\text { dentro de um 'círculo' } \\
\text { em forma de nuvem: } \\
\text { Primeira Lei da } \\
\text { Termodinâmica }\end{array}$ \\
\hline 2 & $\begin{array}{l}\text { Estagiário } \\
\text { Fernando }\end{array}$ & $\begin{array}{l}3 \min 08 \mathrm{~s} \\
\mathrm{a} \\
3 \min 19 \mathrm{~s}\end{array}$ & $\begin{array}{l}\text { (...) quando a gente } \\
\text { refrigera, ...quando a gente } \\
\text { esfria o líquido... a gente } \\
\text { não tá dando nada pra ele, } \\
\text { na verdade a gente tá } \\
\text { tirando dele calor. Quando } \\
\text { a gente tira calor do corpo } \\
\text { ele perde temperatura. }\end{array}$ & \\
\hline 3 & $\begin{array}{l}\text { Estagiário } \\
\text { Fernando }\end{array}$ & $3 \min 19 s$ & Por exemplo, aqui oh!.... & Se dirige para a lousa \\
\hline 4 & $\begin{array}{l}\text { Estagiário } \\
\text { Fernando }\end{array}$ & $3 \min 20 s$ & $\begin{array}{l}\text { A temperatura do bloco A } \\
\text { tá maior que a temperatura } \\
\text { do bloco B. Quando eles } \\
\text { encostam, ...com o tempo } \\
\text { as duas temperaturas vão } \\
\text { ficar iguais. Ou seja, esse } \\
\text { que tá mais quente vai } \\
\text { começar a baixar a } \\
\text { temperatura, porque tá } \\
\text { cedendo calor pro mais } \\
\text { frio. Ou seja, o mais frio vai } \\
\text { começar a subir a } \\
\text { temperatura. Então o } \\
\text { quente começar a baixar, } \\
\text { porque tá dando calor pro } \\
\text { outro. O outro, tá mais } \\
\text { baixo, começa a receber } \\
\text { calor, começa a subir... até } \\
\text { que.. cheguem no mesmo } \\
\text { valor de equilíbrio. Esse é } \\
\text { o princípio. }\end{array}$ & $\begin{array}{l}\text { Mostra na lousa o } \\
\text { desenho de dois blocos } \\
\text { e ao final gesticula com } \\
\text { as duas mãos fazendo } \\
\text { uma descer e a outra } \\
\text { subir. Ao final da sua } \\
\text { fala a estagiária } \\
\text { Adelaide ia apontando } \\
\text { para a lousa a sua } \\
\text { anotação em um círculo } \\
\text { ao final da fala do } \\
\text { estagiário Fernando } \\
\text { quando a Aluna } 1 \text { fala } \\
\text { (linha x) }\end{array}$ \\
\hline 5 & Aluna 1 & $\begin{array}{l}3 \min 48 s \\
\mathrm{a} \\
3 \min 54 \mathrm{~s}\end{array}$ & $\begin{array}{l}\text { É errado colocar... nessa } \\
\text { questão... que teve troca } \\
\text { de energia... dos dois?. }\end{array}$ & $\begin{array}{l}\text { Estagiária Adelaide } \\
\text { aponta rapidamente para } \\
\text { Aluna } 1 \text { e joga o braço } \\
\text { para baixo. Se volta para } \\
\text { a Aluna } 1 . \text { Em seguida, }\end{array}$ \\
\hline
\end{tabular}




\begin{tabular}{|c|c|c|c|c|}
\hline & & & & $\begin{array}{l}\text { deixa a cabeça cair para } \\
\text { o lado. } \\
\text { Estagiário Fernando vem } \\
\text { do outro lado em direção } \\
\text { da Aluna } 1 \text { e fica ao lado } \\
\text { da Estagiária Adelaide e } \\
\text { ao final da fala da Aluna } \\
\text { 1, dá três passos para } \\
\text { trás e começa a falar } \\
\text { (linha 8) }\end{array}$ \\
\hline 6 & $\begin{array}{l}\text { Estagiária } \\
\text { Adelaide }\end{array}$ & $\begin{array}{l}3 \min 55 \mathrm{~s} \\
\mathrm{a} \\
3 \mathrm{~min} 57 \mathrm{~s}\end{array}$ & Não, ...não, ...não é... & $\begin{array}{l}\text { Dá dois passos para trás } \\
\text { e anda para o lado } \\
\text { direito (afastando-se da } \\
\text { Aluna 1) enquanto fala. }\end{array}$ \\
\hline 7 & $\begin{array}{l}\text { Estagiária } \\
\text { Adelaide }\end{array}$ & $\begin{array}{l}3 \min 57 s \\
\mathrm{a} \\
4 \mathrm{~min} 06 \mathrm{~s}\end{array}$ & $\begin{array}{l}\text { Não é errado. Por que é } \\
\text { uma troca de energia, né!? } \\
\text { Mesmo que você esteja } \\
\text { cedendo calor, é uma troca } \\
\text { de energia. Tá!? }\end{array}$ & $\begin{array}{l}\text { Caminha lentamente em } \\
\text { direção à Aluna } 1 .\end{array}$ \\
\hline 8 & $\begin{array}{l}\text { Estagiário } \\
\text { Fernando }\end{array}$ & $\begin{array}{l}3 \min 58 s \\
\mathrm{a} \\
4 \mathrm{~min} 00 \mathrm{~s}\end{array}$ & $\begin{array}{l}\text { Você pode [levar] (pouco } \\
\text { audível) como uma troca } \\
\text { de energia. }\end{array}$ & $\begin{array}{l}\text { Abre bem as duas mãos } \\
\text { (com as palmas voltadas } \\
\text { para baixo) e abre um } \\
\text { pouco os braços ao lado } \\
\text { do corpo, enquanto } \\
\text { caminha para a lousa de } \\
\text { frente para a classe e } \\
\text { costas para a lousa. }\end{array}$ \\
\hline 9 & $\begin{array}{l}\text { Estagiária } \\
\text { Adelaide }\end{array}$ & $\begin{array}{l}4 \min 06 s \\
a \\
4 \min 12 s\end{array}$ & $\begin{array}{l}\text {...porque o corpo trocou } \\
\text { energia. Deixou de ter uma } \\
\text { quantidade de energia. } \\
\text { Que essa é uma da... }\end{array}$ & $\begin{array}{l}\text { Caminha em direção à } \\
\text { lousa e aponta para o } \\
\text { círculo que havia escrito. }\end{array}$ \\
\hline 10 & Aluna 1 & $4 \min 12 s$ & Eu não entendi! & $\begin{array}{l}\text { Fala em voz baixa, mais } \\
\text { audível. }\end{array}$ \\
\hline 11 & $\begin{array}{l}\text { Estagiária } \\
\text { Adelaide }\end{array}$ & $\begin{array}{l}4 \min 13 s \\
\mathrm{a} \\
4 \min 14 \mathrm{~s}\end{array}$ & $\begin{array}{l}\ldots \text { da... das leis da... da lei } \\
\text { zero. }\end{array}$ & $\begin{array}{l}\text { Aluna } 1 \text { está retrucando } \\
\text { em voz baixa (linha 10) }\end{array}$ \\
\hline 12 & $\begin{array}{l}\text { Estagiária } \\
\text { Adelaide }\end{array}$ & $\begin{array}{l}4 \min 14 s \\
\mathrm{a} \\
4 \min 16 \mathrm{~s}\end{array}$ & $\begin{array}{l}\text { Por exemplo... um cor... o } \\
\text { calor de um corpo... }\end{array}$ & $\begin{array}{l}\text { Está próxima à lousa e } \\
\text { apontando para a } \\
\text { mesma onde escreveu o } \\
\text { texto. } \\
\text { Nesse momento, o } \\
\text { estagiário Fernando se } \\
\text { vira de costas para a } \\
\text { estagiária Adelaide e } \\
\text { caminha até a 'mesa de } \\
\text { professor' no outro } \\
\text { canto, e olha para o teto } \\
\text { e depois para o chão. } \\
\text { Vira-se e senta à mesa } \\
\text { (quando ela está falando } \\
\text { “...O que é o calor?” }\end{array}$ \\
\hline
\end{tabular}




\begin{tabular}{|c|c|c|c|c|}
\hline 13 & $\begin{array}{l}\text { Estagiária } \\
\text { Adelaide }\end{array}$ & $\begin{array}{l}4 \min 16 s \\
\mathrm{a} \\
4 \mathrm{~min} 19 \mathrm{~s}\end{array}$ & $\begin{array}{l}\text {...o calor de um corpo... } \\
\text { um calor de um corpo }\end{array}$ & $\begin{array}{l}\text { Está tocando várias } \\
\text { vezes no círculo de sua } \\
\text { anotação. Começa a } \\
\text { aumentar a voz, joga a } \\
\text { cabeça para cima. }\end{array}$ \\
\hline 14 & $\begin{array}{l}\text { Estagiária } \\
\text { Adelaide }\end{array}$ & $\begin{array}{l}4 \min 19 s \\
\mathrm{a} \\
4 \min 22 \mathrm{~s}\end{array}$ & $\begin{array}{l}\text { O que que é energia? O } \\
\text { que é o calor? }\end{array}$ & $\begin{array}{l}\text { Deixa de apontar para a } \\
\text { lousa. Muda a postura } \\
\text { corporal, indo à frente, } \\
\text { em direção à Aluna } 1 \\
\text { com passos } \\
\text { cadenciados e jogando } \\
\text { corpo para o lado e } \\
\text { tendendo a cabeça } \\
\text { levemente para a direita. }\end{array}$ \\
\hline 15 & & & & $\begin{array}{l}\text { Pouco mais de } 1 \mathrm{~s} \text { de } \\
\text { breve silêncio. }\end{array}$ \\
\hline 16 & Aluno 2 & $\begin{array}{l}4 \min 24 s \\
\mathrm{a} \\
4 \min 25 \mathrm{~s}\end{array}$ & $\begin{array}{l}\text { O que que você escreveu } \\
\text { ali em cima? }\end{array}$ & $\begin{array}{l}\text { Estagiária Adelaide para } \\
\text { de falar com a Aluna } 1 \text { e } \\
\text { gira o corpo para o } \\
\text { Aluno } 2 \text {, continuando } \\
\text { giro no sentido da lousa } \\
\text { e seque para a lousa. }\end{array}$ \\
\hline 17 & $\begin{array}{l}\text { Estagiária } \\
\text { Adelaide }\end{array}$ & $4 \min 26 s$ & & $\begin{array}{l}\text { Estagiária Adelaide } \\
\text { aperta os lábios por } \\
\text { cerca de } 1 \mathrm{~s} \text { (fazendo } \\
\text { sumir a parte vermelha) }\end{array}$ \\
\hline 18 & $\begin{array}{l}\text { Estagiária } \\
\text { Adelaide }\end{array}$ & $\begin{array}{l}4 \min 27 s \\
\mathrm{a} \\
4 \min 30 \mathrm{~s}\end{array}$ & $\begin{array}{l}\text { A lei zero? ...aqui eu só dei } \\
\text { uma somarizada, tá!? }\end{array}$ & \\
\hline 19 & Aluno 2 & $\begin{array}{l}4 \min 30 s \\
\mathrm{a} \\
4 \min 31 \mathrm{~s}\end{array}$ & Tá escrito o quê? & \\
\hline 20 & $\begin{array}{l}\text { Estagiária } \\
\text { Adelaide }\end{array}$ & $\begin{array}{l}4 \mathrm{~min} 32 \mathrm{~s} \\
\mathrm{a} \\
4 \mathrm{~min} 40 \mathrm{~s}\end{array}$ & $\begin{array}{l}\text { Quer dizer o que? ...que o } \\
\text { corpo mais quente cede } \\
\text { pro corpo ma... me... com } \\
\text { menos, ha..., calor. Tá!? } \\
\text { Isso é a lei zero da } \\
\text { termodinâmica. }\end{array}$ & $\begin{array}{l}\text { Aponta para a frase que } \\
\text { está na lousa, dentro do } \\
\text { círculo que ela escreveu. }\end{array}$ \\
\hline 21 & $\begin{array}{l}\text { Estagiário } \\
\text { Fernando }\end{array}$ & $\begin{array}{l}4 \min 41 s \\
\text { a } \\
4 \min 43 s\end{array}$ & $\begin{array}{l}\text { Ou seja: é o sentido que } \\
\text { vai do quente pro frio. }\end{array}$ & $\begin{array}{l}\text { Sentado na carteira, } \\
\text { gesticula com a mão } \\
\text { esquerda (ele é canhoto) } \\
\text { indicando movimento de } \\
\text { um sentido para outro. }\end{array}$ \\
\hline 22 & $\begin{array}{l}\text { Estagiária } \\
\text { Adelaide }\end{array}$ & $\begin{array}{l}4 \min 42 s \\
a \\
4 \min 45 s\end{array}$ & $\begin{array}{l}\text {...é o sentido que vai do } \\
\text { quente para o frio. Tá } \\
\text { bom!? }\end{array}$ & $\begin{array}{l}\text { Gesticula com as duas } \\
\text { mãos indicando ida de } \\
\text { um ponto para outro. }\end{array}$ \\
\hline 23 & $\begin{array}{l}\text { Estagiária } \\
\text { Adelaide }\end{array}$ & $\begin{array}{l}4 \min 45 s \\
\mathrm{a} \\
5 \min 01 \mathrm{~s}\end{array}$ & $\begin{array}{l}\text { Então, voltando aqui... O... } \\
\text { o calor de um corpo, ele tá } \\
\text { relacionado ao quê? A } \\
\text { diferença entre as } \\
\text { temperaturas, quando ele } \\
\text { está em contato com outro } \\
\text { corpo. O calor específico é } \\
\text { do próprio material. Por }\end{array}$ & $\begin{array}{l}\text { Aponta diversas vezes } \\
\text { para a lousa no círculo } \\
\text { em que havia escrito } \\
\text { uma frase e a equação } \\
\mathrm{Q}=\mathrm{m} . c . \Delta \mathrm{T}\end{array}$ \\
\hline
\end{tabular}




\begin{tabular}{|c|c|c|c|c|}
\hline & & & $\begin{array}{l}\text { exemplo, a madeira e o } \\
\text { ferro... E tem o quê? }\end{array}$ & \\
\hline 24 & $\begin{array}{l}\text { Estagiária } \\
\text { Adelaide }\end{array}$ & $5 \mathrm{~min} 02 \mathrm{~s}$ & Qual que é o seu nome? & Aponta para Aluna 3. \\
\hline 25 & Aluna 3 & $\begin{array}{l}5 \min 03 \mathrm{~s} \\
\mathrm{a} \\
5 \min 04 \mathrm{~s}\end{array}$ & $\begin{array}{l}\text {...sou eu..., é .... Nikita } \\
\text { (nome fictício) }\end{array}$ & $\begin{array}{l}\text { Aponta para si mesma, } \\
\text { demonstra surpresa. }\end{array}$ \\
\hline 26 & $\begin{array}{l}\text { Estagiária } \\
\text { Adelaide }\end{array}$ & $\begin{array}{l}5 \min 04 s \\
a \\
5 \min 16 s\end{array}$ & $\begin{array}{l}\text { Nikita! ...E a Nikita disse o } \\
\text { seguinte: Se eu tiver mais } \\
\text { gelo... eu consigo resfriar o } \\
\text { refrigerante mais rápido. } \\
\text { Quer dizer o quê? Que a } \\
\text { massa... }\end{array}$ & $\begin{array}{l}\text { Se volta para lousa e } \\
\text { coloca a letra } \mathrm{m} \\
\text { complementando } \\
\text { fórmula. }\end{array}$ \\
\hline 27 & & $\begin{array}{l}5 \min 16 s \\
a \\
5 \min 19 s\end{array}$ & & Silêncio \\
\hline 28 & $\begin{array}{l}\text { Estagiária } \\
\text { Adelaide }\end{array}$ & $\begin{array}{l}5 \min 19 s \\
\mathrm{a} \\
5 \min 22 \mathrm{~s}\end{array}$ & $\begin{array}{l}\text {...do corpo, também } \\
\text { influencia no calor. }\end{array}$ & Se volta para a classe. \\
\hline 29 & $\begin{array}{l}\text { Estagiária } \\
\text { Adelaide }\end{array}$ & $\begin{array}{l}5 \mathrm{~min} 22 \mathrm{~s} \\
\mathrm{a} \\
5 \mathrm{~min} 31 \mathrm{~s}\end{array}$ & $\begin{array}{l}\text { Então, essa... essa fó... } \\
\text { essa equação aqui... é a } \\
\text { e... equação de... do calor } \\
\text { de um corpo. Tá? }\end{array}$ & $\begin{array}{l}\text { Se volta para a lousa e } \\
\text { fica fazendo rabiscos de } \\
\text { reforços nas letras. }\end{array}$ \\
\hline 30 & Aluna 1 & $\begin{array}{l}5 \mathrm{~min} 28 \mathrm{~s} \\
\mathrm{a} \\
5 \mathrm{~min} 35 \mathrm{~s}\end{array}$ & & $\begin{array}{l}\text { A Aluna } 1 \text { está se } \\
\text { mexendo, põe a mão na } \\
\text { testa, na cabeça, na } \\
\text { carteira; está irrequieta, } \\
\text { com a mão na cabeça, } \\
\text { inclina a cabeça para a } \\
\text { parede lateral. } \\
\text { Resmunga algo [Não tô } \\
\text { entendendo] (?) }\end{array}$ \\
\hline 31 & $\begin{array}{l}\text { Estagiária } \\
\text { Adelaide }\end{array}$ & $\begin{array}{l}5 \min 32 s \\
\mathrm{a} \\
5 \min 33 \mathrm{~s}\end{array}$ & Vocês entenderam? & $\begin{array}{l}\text { Se volta para a classe } \\
\text { mais rapidamente que } \\
\text { das outras vezes. A } \\
\text { Aluna } 1 \text { está } \\
\text { resmungando [Não tô } \\
\text { entendendo] (?). }\end{array}$ \\
\hline 32 & $\begin{array}{l}\text { Estagiária } \\
\text { Adelaide }\end{array}$ & $\begin{array}{l}5 \min 35 s \\
a \\
5 \min 36 s\end{array}$ & $\begin{array}{l}\text { Que que você não } \\
\text { entendeu? }\end{array}$ & $\begin{array}{l}\text { Nesse momento, } \\
\text { estagiária Adelaide olha } \\
\text { para a Aluna 1, aponta o } \\
\text { dedo para ela, faz } \\
\text { movimento cadenciado } \\
\text { inicialmente indo em } \\
\text { direção à ela, mas sai } \\
\text { para o lado. }\end{array}$ \\
\hline 33 & $\begin{array}{l}\text { Estagiária } \\
\text { Adelaide }\end{array}$ & $\begin{array}{l}5 \min 36 s \\
\mathrm{a} \\
5 \min 38 \mathrm{~s}\end{array}$ & $\begin{array}{l}\text {...você tá com dúvida aí } \\
\text { ainda. Diga. }\end{array}$ & $\begin{array}{l}\text { Quase todos os alunos } \\
\text { se viram e voltam o olhar } \\
\text { para a Aluna } 1 .\end{array}$ \\
\hline 34 & Aluna 1 & $\begin{array}{l}5 \min 38 s \\
\mathrm{a} \\
5 \min 40 \mathrm{~s}\end{array}$ & Não. (...) (fala inaudível) & Sorriso acanhado \\
\hline
\end{tabular}




\begin{tabular}{|c|c|c|c|c|}
\hline 35 & $\begin{array}{l}\text { Estagiária } \\
\text { Adelaide }\end{array}$ & $5 \mathrm{~min} 41 \mathrm{~s}$ & & $\begin{array}{l}\text { Olha para o estagiário } \\
\text { Fernando. }\end{array}$ \\
\hline 36 & $\begin{array}{l}\text { Estagiária } \\
\text { Adelaide }\end{array}$ & $\begin{array}{l}5 \min 42 s \\
a \\
5 \min 43 s\end{array}$ & Pensando na vida, né!? & $\begin{array}{l}\text { Dá um sorriso tímido e } \\
\text { vira bruscamente para a } \\
\text { lousa, mas olhando para } \\
\text { a Aluna } 1\end{array}$ \\
\hline 37 & $\begin{array}{l}\text { Estagiário } \\
\text { Fernando }\end{array}$ & $\begin{array}{l}5 \min 42 s \\
\mathrm{a} \\
5 \min 43 \mathrm{~s}\end{array}$ & Lembrando que o Q ... & $\begin{array}{l}\text { la apontando na lousa } \\
\text { quando para } \\
\text { bruscamente, abaixa o } \\
\text { braço e fica junto à lousa } \\
\text { com a mão esquerda } \\
\text { apoiada na canaleta da } \\
\text { lousa e parece olhar } \\
\text { para a câmera do fundo } \\
\text { da sala, ou querendo } \\
\text { ouvir o que a Aluna } 1 \\
\text { resmungava. }\end{array}$ \\
\hline 38 & & $\begin{array}{l}5 \min 44 s \\
a \\
5 \min 49 s\end{array}$ & & $\begin{array}{l}\text { Silêncio dos estagiários } \\
\text { e da classe, com alguns } \\
\text { resmungos de duas } \\
\text { alunas que estavam } \\
\text { conversando sobre um } \\
\text { trabalho que estavam } \\
\text { copiando em classe } \\
\text { desde o início da aula. } \\
\text { Aluna } 1 \text { também estava } \\
\text { resmungando, mas } \\
\text { muito baixo. }\end{array}$ \\
\hline 39 & $\begin{array}{l}\text { Estagiário } \\
\text { Fernando }\end{array}$ & $\begin{array}{l}5 \min 49 s \\
a \\
6 \min 11 s\end{array}$ & $\begin{array}{l}\text { Lembrando para vocês } \\
\text { que o Q na equação é a } \\
\text { quantidade de calor. Que } \\
\text { é a mesma coisa que } \\
\text { energia. M é a massa... do } \\
\text { corpo. Que tá cedendo... } \\
\text { ou recebendo esse calor. } \\
\text { Delta t a variação de } \\
\text { temperatura. E o c o calor } \\
\text { específico. O c, o calor } \\
\text { específico, é uma } \\
\text { característica de cada } \\
\text { material. }\end{array}$ & $\begin{array}{l}\text { (Antes, ficou brevemente } \\
\text { em silêncio como se } \\
\text { quisesse ouvir o que a } \\
\text { Aluna } 1 \text { resmungava) }\end{array}$ \\
\hline 40 & $\begin{array}{l}\text { Estagiário } \\
\text { Fernando }\end{array}$ & $\begin{array}{l}6 \mathrm{~min} 11 \mathrm{~s} \\
\mathrm{a} \\
6 \mathrm{~min} 22 \mathrm{~s}\end{array}$ & $\begin{array}{l}\text { É isso que difere de } \\
\text { material para material e faz } \\
\text { esse lance que a gente } \\
\text { tava discutindo no início, } \\
\text { da sensibilidade ser } \\
\text { diferente com relação à } \\
\text { madeira e com relação o } \\
\text { metal. }\end{array}$ & $\begin{array}{l}\text { Se dirige à porta e toca a } \\
\text { maçaneta. }\end{array}$ \\
\hline
\end{tabular}




\section{APÊNDICE G: TRANSCRIÇÃO DO EPISÓDIO 7}

\begin{tabular}{|c|c|c|c|c|}
\hline \multicolumn{5}{|c|}{ Episódio 7} \\
\hline Linha & Participante & Tempo & Processos verbais & Processos não verbais \\
\hline 1 & $\begin{array}{l}\text { Estagiária } \\
\text { Leila }\end{array}$ & $\begin{array}{l}\text { antes dos } \\
6 \mathrm{~min} 08 \mathrm{~s}\end{array}$ & $\begin{array}{l}\text { (estava explicando } \\
\text { princípio da inércia com } \\
\text { enunciado colocado na tela } \\
\text { de uma TV) }\end{array}$ & $\begin{array}{l}\text { Apontando para a TV, lê o } \\
\text { princípio da inércia. }\end{array}$ \\
\hline 2 & $\begin{array}{l}\text { Estagiária } \\
\text { Leila }\end{array}$ & $\begin{array}{l}6 \min 08 s \text { a } \\
6 \min 10 s\end{array}$ & $\begin{array}{l}\text { Alguém pega ônibus aqui? } \\
\text {... Não né!? }\end{array}$ & $\begin{array}{l}\text { Abre as duas mãos na altura } \\
\text { da cintura com as palmas } \\
\text { voltadas para cima e braços } \\
\text { com } 90^{\circ} \text {. Em seguida dá } \\
\text { alguns passos à frente, na } \\
\text { direção dos alunos. }\end{array}$ \\
\hline 3 & Aluno 1 & $6 \min 11 \mathrm{~s}$ & Todos. & \\
\hline 4 & Aluna 2 & $6 \min 12 s$ & Todo mundo. & \\
\hline 5 & $\begin{array}{l}\text { Estagiária } \\
\text { Leila }\end{array}$ & $\begin{array}{l}6 \min 13 s \text { a } \\
6 \min 20 s\end{array}$ & $\begin{array}{l}\text { Então, o ônibus. Aqui tem } \\
\text { um exemplo. O que que tá } \\
\text { acontecendo aqui? Só.. } \\
\text { Tenta imaginar só essa } \\
\text { figura aqui. }\end{array}$ & $\begin{array}{l}\text { Vai até à TV, próxima à } \\
\text { porta, e aponta com a mão } \\
\text { esquerda o ônibus. }\end{array}$ \\
\hline 6 & Aluna 2 & $\begin{array}{l}6 \min 21 s \text { a } \\
6 \min 23 s\end{array}$ & $\begin{array}{l}\text { Tá dentro do ônibus, } \\
\text { segurando. }\end{array}$ & $\begin{array}{l}\text { Estagiária Leila volta para } \\
\text { mais próxima da primeira } \\
\text { carteira central. }\end{array}$ \\
\hline 7 & $\begin{array}{l}\text { Estagiária } \\
\text { Leila }\end{array}$ & $\begin{array}{l}6 \min 24 s \text { a } \\
6 \min 26 s\end{array}$ & $\begin{array}{l}\text { Você tá parado? [parte não } \\
\text { audível] }\end{array}$ & $\begin{array}{l}\text { Aponta o dedo ligeiramente } \\
\text { para o alto e coça uma mão } \\
\text { na outra. }\end{array}$ \\
\hline 8 & $\begin{array}{l}\text { Estagiária } \\
\text { Leila }\end{array}$ & $\begin{array}{c}6 \min 27 s \text { a } \\
6 \min 28 s\end{array}$ & $\begin{array}{l}\text { Você tá parado? [O } \\
\text { corpo?] [final pouco } \\
\text { audível por início de muitas } \\
\text { falas dos alunos] }\end{array}$ & $\begin{array}{l}\text { Para de coçar as mãos e } \\
\text { joga as duas para os lados. }\end{array}$ \\
\hline 9 & Aluno 1 & $\begin{array}{c}6 \min 28 s \text { a } \\
6 \min 30 s\end{array}$ & Nossa! Vocêêê & $\begin{array}{l}\text { Vários alunos estão falando } \\
\text { diversas coisas, algumas }\end{array}$ \\
\hline 10 & Aluno 3 & $6 \min 30 s$ & Parado. & não distinguíveis. \\
\hline 11 & Aluna 4 & $6 \mathrm{~min} 30 \mathrm{~s}$ & Tá em movimento. & \\
\hline 12 & Aluna 2 & $\begin{array}{l}6 \min 31 s \mathrm{a} \\
6 \mathrm{~min} 35 \mathrm{~s}\end{array}$ & $\begin{array}{l}\text { Ah! Ali achei que tava } \\
\text { parado. [final pouco } \\
\text { audível] }\end{array}$ & Estagiária está sorrindo. \\
\hline 13 & $\begin{array}{l}\text { Estagiária } \\
\text { Leila }\end{array}$ & $\begin{array}{l}6 \min 36 s \text { a } \\
6 \min 38 s\end{array}$ & $\begin{array}{l}\text { Tá certo. Só tô te } \\
\text { provocando. }\end{array}$ & $\begin{array}{l}\text { Estagiária ri enquanto fala, } \\
\text { balança a cabeça para cima } \\
\text { e para baixo e aponta para } \\
\text { Aluna } 2 \text {. }\end{array}$ \\
\hline 14 & $\begin{array}{l}\text { Estagiária } \\
\text { Leila }\end{array}$ & $\begin{array}{l}6 \min 38 s \text { a } \\
6 \min 41 s\end{array}$ & $\begin{array}{l}\text { Não. Você tava assim... Se } \\
\text { você olhar pra pessoa que } \\
\text { tava sentada... }\end{array}$ & $\begin{array}{l}\text { Gesticula com as duas mãos } \\
\text { à frente do corpo, movendo- } \\
\text { as de um lado para o outro } \\
\text { com as palmas para cima. } \\
\text { Em seguida, aponta para a } \\
\text { imagem do ônibus na TV. }\end{array}$ \\
\hline
\end{tabular}




\begin{tabular}{|c|c|c|c|c|}
\hline 15 & $\begin{array}{l}\text { Aluno (não } \\
\text { identificado) }\end{array}$ & $6 \min 40 s$ & (riso de um aluno) & $\begin{array}{l}\text { Um aluno dá uma risada } \\
\text { curta e rápida em alto som. }\end{array}$ \\
\hline 16 & Aluna 2 & $\begin{array}{c}6 \min 41 \mathrm{~s} a \\
6 \min 45 \mathrm{~s}\end{array}$ & $\begin{array}{l}\text { Agora, pra mim, quem tá } \\
\text { andando, não tá. Tá em } \\
\text { movimento. }\end{array}$ & $\begin{array}{l}\text { Estagiária Leila se aproxima } \\
\text { novamente da TV e aponta } \\
\text { para o desenho do ônibus. } \\
\text { Balança a cabeça para cima } \\
\text { e para baixo. Está sorrindo. }\end{array}$ \\
\hline 17 & $\begin{array}{l}\text { Estagiária } \\
\text { Leila }\end{array}$ & $\begin{array}{l}6 \min 46 s \mathrm{a} \\
6 \min 50 \mathrm{~s}\end{array}$ & $\begin{array}{l}\text { Então. Aqui você está...? } \\
\text { Parada? }\end{array}$ & Aponta para figura na TV. \\
\hline 18 & Aluna 2 & $6 \min 51 s$ & Tá em repouso. & \\
\hline 19 & Aluno 1 & $6 \min 52 s$ & Movimento. & \\
\hline 20 & Aluno 5 & $\begin{array}{l}6 \min 52 s \text { a } \\
6 \min 56 s\end{array}$ & $\begin{array}{l}\text { Tá dando ré. Óh! Aí tá } \\
\text { dando ré. Você ... } \\
\text { (inaudível) }\end{array}$ & $\begin{array}{l}\text { Estagiária Leila aponta para } \\
\text { Aluno 5, sorrindo e olha para } \\
\text { Aluna 2. Ergue a mão } \\
\text { esquerda a meia altura } \\
\text { quase fazendo 'não' com o } \\
\text { dedo indicador e então inicia } \\
\text { a fala da linha } 21 .\end{array}$ \\
\hline 21 & $\begin{array}{l}\text { Estagiária } \\
\text { Leila }\end{array}$ & $\begin{array}{l}6 \min 55 s \text { a } \\
6 \min 59 s\end{array}$ & $\begin{array}{l}\text { Mas, se eu disser para } \\
\text { você que você não está } \\
\text { em repouso? Você vai } \\
\text { acreditar? }\end{array}$ & $\begin{array}{l}\text { Vai próximo à primeira } \\
\text { carteira da fileira do meio e } \\
\text { joga a mão direita (apenas } \\
\text { com o indicador aberto) para } \\
\text { frente e para baixo, olhando } \\
\text { para Aluna } 2 \text {. }\end{array}$ \\
\hline 22 & Aluna 2 & $\begin{array}{l}6 \min 59 s a \\
7 \min 03 s\end{array}$ & $\begin{array}{l}\text { Como assim? .... se ele } \\
\text { estiver movimentando.... } \\
\text { ele tá andando. }\end{array}$ & \\
\hline 23 & $\begin{array}{l}\text { Aluno (não } \\
\text { identificado) }\end{array}$ & $7 \mathrm{~min} 02 \mathrm{~s}$ & Acredito. & \\
\hline 24 & $\begin{array}{l}\text { Vários alunos } \\
\text { e Estagiária } \\
\text { Leila }\end{array}$ & $\begin{array}{l}7 \min 02 s \mathrm{a} \\
7 \min 11\end{array}$ & $\begin{array}{l}\text { [muitas falas simultâneas, } \\
\text { confuso] }\end{array}$ & $\begin{array}{l}\text { Ao final, estagiária Leila vem } \\
\text { para o meio da sala, entre as } \\
\text { carteiras, mais próxima do } \\
\text { Aluno } 6 \text { (ao fundo da sala) }\end{array}$ \\
\hline 25 & $\begin{array}{l}\text { Estagiária } \\
\text { Leila }\end{array}$ & $7 \min 11 \mathrm{~s}$ & Que o quê? & $\begin{array}{l}\text { Se dirige ao Aluno } 6 \text {, que } \\
\text { estava explicando em meio a } \\
\text { muitas falas simultâneas. }\end{array}$ \\
\hline 26 & Aluno 6 & $\begin{array}{l}7 \min 11 s a \\
7 \min 24 s\end{array}$ & $\begin{array}{l}\text { Você está em cima de um } \\
\text { objeto... É. Se você está } \\
\text { em cima de um objeto e } \\
\text { ele está andando, você } \\
\text { está em movimento. } \\
\text { Porque você vai em cima } \\
\text { de um objeto que ele está } \\
\text { em movimento que você } \\
\text { está aí parado ou em } \\
\text { repouso. Você está se } \\
\text { movendo. De qualquer } \\
\text { forma. }\end{array}$ & \\
\hline 27 & Aluno 7 & $7 \mathrm{~min} 23 \mathrm{~s}$ & Putz! Que gênio! & $\begin{array}{l}\text { Risos de parte da classe. } \\
\text { Estagiária Leila fica com } \\
\text { sorriso fixo no rosto e se } \\
\text { volta para o Aluno } 8 \text {, do outro } \\
\text { lado da sala, que inicia fala. }\end{array}$ \\
\hline
\end{tabular}




\begin{tabular}{|c|c|c|c|c|}
\hline 28 & Aluno 8 & $\begin{array}{c}7 \min 26 s a \\
7 \min 31 s\end{array}$ & $\begin{array}{l}\text { Não! Se tá se movendo... } \\
\text { você tá parado, você tá } \\
\text { parado! Não tá se } \\
\text { movendo! [final inaudível] }\end{array}$ & $\begin{array}{l}\text { Muitos alunos começam falar } \\
\text { ao mesmo tempo, tornando } \\
\text { incompreensível as falas. }\end{array}$ \\
\hline 29 & $\begin{array}{l}\text { Vários alunos } \\
\text { falando ao } \\
\text { mesmo } \\
\text { tempo } \\
\end{array}$ & $\begin{array}{l}7 \min 31 s a \\
7 \min 49 s\end{array}$ & [falas não compreensíveis] & $\begin{array}{l}\text { Estagiária Leila se } \\
\text { movimenta indo hora mais } \\
\text { para próximo de um aluno ou } \\
\text { de outro que está falando. }\end{array}$ \\
\hline 30 & $\begin{array}{c}\text { Aluno ao } \\
\text { fundo (não } \\
\text { identificado) }\end{array}$ & $\begin{array}{l}7 \min 49 s a \\
7 \min 54 s\end{array}$ & $\begin{array}{l}\text { Eu acho que você tá } \\
\text { parado porquê... A Terra } \\
\text { tá dando volta e.... }\end{array}$ & $\begin{array}{l}\text { Parte da classe começa a } \\
\text { dar risadas com o final da } \\
\text { fala do aluno. }\end{array}$ \\
\hline 31 & $\begin{array}{l}\text { Estagiária } \\
\text { Leila }\end{array}$ & $\begin{array}{l}7 \min 55 s a \\
7 \min 56 s\end{array}$ & $\begin{array}{l}\text { Não, vamos fazer uma } \\
\text { enquete. }\end{array}$ & $\begin{array}{l}\text { Alguns alunos ainda estão } \\
\text { rindo. Estagiária sorri e abre } \\
\text { os braços. dá dois passo } \\
\text { cadenciados para frente da } \\
\text { classe e para bruscamente } \\
\text { para retornar para próximo à } \\
\text { TV. }\end{array}$ \\
\hline 32 & $\begin{array}{l}\text { Estagiária } \\
\text { Leila }\end{array}$ & $\begin{array}{l}7 \min 58 s \text { a } \\
8 \min 00 s\end{array}$ & Quem acha... & $\begin{array}{l}\text { Retorna para próximo da TV } \\
\text { e aponta para figura do } \\
\text { ônibus na TV. }\end{array}$ \\
\hline 33 & $\begin{array}{l}\text { Estagiária } \\
\text { Leila }\end{array}$ & $\begin{array}{l}8 \min 00 \mathrm{~s} a \\
8 \mathrm{~min} 03 \mathrm{~s}\end{array}$ & $\begin{array}{l}\text {...que essas duas pessoas } \\
\text { aqui estão paradas? }\end{array}$ & $\begin{array}{l}\text { Aponta o dedo para a figura } \\
\text { do ônibus, encostado o dedo } \\
\text { na tela de TV e inclinando a } \\
\text { cabeça para frente (na } \\
\text { direção da TV) em seguida, } \\
\text { se afasta da TV e vai à frente } \\
\text { da classe. }\end{array}$ \\
\hline 34 & $\begin{array}{l}\text { Estagiária } \\
\text { Leila }\end{array}$ & $8 \mathrm{~min} 04 \mathrm{~s}$ & Levanta a mão. & $\begin{array}{l}\text { Estagiária ergue o braço } \\
\text { direito. Breve silêncio de } \\
\text { quase 1s. }\end{array}$ \\
\hline 35 & $\begin{array}{l}\text { Aluno (não } \\
\text { identificado) }\end{array}$ & $\begin{array}{l}8 \min 05 s \mathrm{a} \\
8 \min 07 \mathrm{~s}\end{array}$ & $\begin{array}{l}\text { Eu também. Elas estão } \\
\text { paradas. }\end{array}$ & $\begin{array}{l}\text { Aluno } 8 \text { está com o braço } \\
\text { direito levantado. Um aluno } \\
\text { dá uma risada curta e alto } \\
\text { som. }\end{array}$ \\
\hline 36 & Aluno 8 & $8 \mathrm{~min} 08 \mathrm{~s}$ & Estão paradas. & Abaixa o braço. \\
\hline 37 & $\begin{array}{l}\text { Estagiária } \\
\text { Leila }\end{array}$ & $\begin{array}{c}8 \min 09 s \text { a } \\
8 \min 14 s\end{array}$ & $\begin{array}{l}\text { Quem acha... que... elas } \\
\text { estão... em movimento? }\end{array}$ & $\begin{array}{l}\text { Estagiária está à frente e } \\
\text { move-se lentamente um } \\
\text { pouco para direita, um pouco } \\
\text { para a esquerda. }\end{array}$ \\
\hline 38 & Vários alunos & $\begin{array}{l}8 \min 14 s \text { a } \\
8 \min 19 s\end{array}$ & [muitas falas simultâneas] & Muitas falas simultâneas. \\
\hline 39 & Aluna 9 & $\begin{array}{l}8 \min 16 s \text { a } \\
8 \min 21 s\end{array}$ & $\begin{array}{l}\text { [começo incompreensível] } \\
\text { Mas estão paradas. }\end{array}$ & \\
\hline 40 & $\begin{array}{l}\text { Estagiária } \\
\text { Leila }\end{array}$ & $\begin{array}{l}8 \min 21 s \mathrm{a} \\
8 \mathrm{~min} 22 \mathrm{~s}\end{array}$ & As duas estão paradas!? & \\
\hline 41 & Aluna 9 & $8 \min 22 s$ & Isso. & \\
\hline 42 & $\begin{array}{l}\text { Aluno (não } \\
\text { identificado) }\end{array}$ & $\begin{array}{l}8 \min 22 s \text { a } \\
8 \min 23 s\end{array}$ & $\begin{array}{l}\text { Dependendo de ... } \\
\text { [incompreensível] não. }\end{array}$ & \\
\hline 43 & $\begin{array}{l}\text { Estagiária } \\
\text { Leila }\end{array}$ & $\begin{array}{l}8 \min 22 s \mathrm{a} \\
8 \min 34 \mathrm{~s}\end{array}$ & $\begin{array}{l}\text { Então, quando você ... } \\
\text { [incompreensível] }\end{array}$ & $\begin{array}{l}\text { Muitos alunos estão falando } \\
\text { junto com a estagiária Leila, } \\
\text { que permanece com sorriso } \\
\text { fixo depois de falar e vários }\end{array}$ \\
\hline
\end{tabular}




\begin{tabular}{|c|c|c|c|c|}
\hline & & & & $\begin{array}{l}\text { alunos continuam falando } \\
\text { juntos. }\end{array}$ \\
\hline 44 & $\begin{array}{l}\text { Aluno (não } \\
\text { identificado) }\end{array}$ & $\begin{array}{l}8 \min 34 s \text { a } \\
8 \min 36 s\end{array}$ & $\begin{array}{l}\text { Você não tem nenhum } \\
\text { [incompreensível] } \\
\text { [correndo]. }\end{array}$ & \\
\hline 45 & Aluna 9 & $8 \mathrm{~min} 36 \mathrm{~s}$ & É! & \\
\hline 46 & Vários alunos & $\begin{array}{l}8 \min 36 s \mathrm{a} \\
8 \min 49 \mathrm{~s}\end{array}$ & \multicolumn{2}{|c|}{ [muitas falas, incompreensíveis] } \\
\hline 47 & $\begin{array}{l}\text { Estagiária } \\
\text { Leila }\end{array}$ & $\begin{array}{l}8 \min 50 s \text { a } \\
8 m i n 58 s\end{array}$ & $\begin{array}{l}\text { É muito legal isso que } \\
\text { vocês estão falando. } \\
\text { Porquê... é... é... é isso } \\
\text { que a gente tem que } \\
\text { pensar. Parado? Ou a } \\
\text { gente tá em movimento? }\end{array}$ & \\
\hline 48 & Aluno 10 & $\begin{array}{l}8 \mathrm{mi59} a \\
9 \min 05 \mathrm{~s}\end{array}$ & $\begin{array}{l}\text { [fala em tom muito baixo, } \\
\text { aluno está sentado em } \\
\text { frente à estagiária] Final da } \\
\text { fala: Que nem ali em cima, } \\
\text { tem uma flechinha... }\end{array}$ & $\begin{array}{l}\text { Estagiária Leila, após ouvir } \\
\text { aluno, se dirige para próximo } \\
\text { da TV e aponta a para figura } \\
\text { do ônibus e inicia fala } \\
\text { seguinte. Aluno } 10 \text { está na } \\
\text { primeira carteira à frente e } \\
\text { meio, virado de lado para o } \\
\text { resto da classe e voltado } \\
\text { para TV. }\end{array}$ \\
\hline 49 & $\begin{array}{l}\text { Estagiária } \\
\text { Leila }\end{array}$ & $\begin{array}{l}9 \min 06 \mathrm{~s} a \\
9 \min 11 \mathrm{~s}\end{array}$ & $\begin{array}{l}\text { Tá! Vamos supor que ele } \\
\text { tivesse essa flechinha. E } \\
\text { eu estivesse falando que } \\
\text { ele tava andando. [pausa } \\
\text { breve] Mudaria alguma } \\
\text { coisa? }\end{array}$ & $\begin{array}{l}\text { Alguns alunos ao fundo } \\
\text { (próximos à câmera) estão } \\
\text { conversando sobre que } \\
\text { aulas terão hoje, que dia terá } \\
\text { aula de determinada matéria. } \\
\text { Dificultando ouvir o que a } \\
\text { estagiária Leila está falando. } \\
\text { Mas os demais estão em } \\
\text { silêncio e atentos prestando } \\
\text { atenção na fala da } \\
\text { professora. }\end{array}$ \\
\hline 50 & Aluno 10 & $\begin{array}{l}9 \min 11 \mathrm{~s} a \\
9 \min 13 \mathrm{~s}\end{array}$ & Aí mudaria. Tá andando. & \\
\hline 51 & $\begin{array}{l}\text { Estagiária } \\
\text { Leila }\end{array}$ & $\begin{array}{l}9 \min 14 s \text { a } \\
9 \min 29 s\end{array}$ & $\begin{array}{l}\text { Então. Eu vou dizer para } \\
\text { vocês que... Todo mundo } \\
\text { tá certo. Ninguém tá } \\
\text { errado. Todo mundo tá } \\
\text { certo. Isso vai depender do } \\
\text { referencial de vocês. } \\
\text { Então, se você [não } \\
\text { audível] vai falar pra ele } \\
\text { assim: }\end{array}$ & $\begin{array}{l}\text { Estagiária Leila está à frente } \\
\text { da classe. Gesticula com as } \\
\text { duas mãos enquanto fala. } \\
\text { Alunos ao fundo continuam } \\
\text { falando próximo à câmera. } \\
\text { Restante da classe está } \\
\text { atenta à fala da estagiária. }\end{array}$ \\
\hline 52 & $\begin{array}{l}\text { Estagiária } \\
\text { Leila }\end{array}$ & $\begin{array}{l}9 \min 29 s \mathrm{a} \\
9 \min 42 \mathrm{~s}\end{array}$ & $\begin{array}{l}\text { Vocês estão parados. Mas, } \\
\text { em relação a quem tá de } \\
\text { fora, vai ver que [inaudível] } \\
\text { está em movimento. Vocês } \\
\text { estão em movimento. E o } \\
\text { outro, não está em } \\
\text { movimento. }\end{array}$ & $\begin{array}{l}\text { Estagiária Leila vai para } \\
\text { próximo da TV e aponta } \\
\text { desenho do ônibus e em } \\
\text { seguida retorna ao centro da } \\
\text { classe à frente. }\end{array}$ \\
\hline 53 & $\begin{array}{l}\text { Estagiária } \\
\text { Leila }\end{array}$ & $\begin{array}{l}9 \min 42 s \mathrm{a} \\
9 \min 45 \mathrm{~s}\end{array}$ & $\begin{array}{l}\text { Então, pensem nisso. } \\
\text { Depende. }\end{array}$ & $\begin{array}{l}\text { Estagiária Leila começa } \\
\text { passar entre carteiras e abre }\end{array}$ \\
\hline
\end{tabular}




\begin{tabular}{|c|c|c|c|c|}
\hline & & & & $\begin{array}{l}\text { um sorriso, fazendo } \\
\text { entonação mais forte ao final } \\
\text { da frase. }\end{array}$ \\
\hline 54 & $\begin{array}{l}\text { Estagiária } \\
\text { Leila }\end{array}$ & $\begin{array}{l}9 \min 45 s \mathrm{a} \\
9 \min 49 \mathrm{~s}\end{array}$ & $\begin{array}{l}\text { Se alguém perguntar para } \\
\text { você. Você fala(sic): Você } \\
\text { está parado? }\end{array}$ & $\begin{array}{l}\text { Ergue mão esquerda à altura } \\
\text { da cabeça e a joga para } \\
\text { frente. }\end{array}$ \\
\hline 55 & $\begin{array}{l}\text { Estagiária } \\
\text { Leila }\end{array}$ & $\begin{array}{l}9 \min 50 \mathrm{~s} a \\
9 \min 54 \mathrm{~s}\end{array}$ & $\begin{array}{l}\text { Depende! Com relação ao } \\
\text { quê? }\end{array}$ & $\begin{array}{l}\text { Estagiária volta de costas } \\
\text { para a lousa, dando passos } \\
\text { lentos para trás. E realiza } \\
\text { balanços rápidos com a } \\
\text { cabeça na direção vertical. }\end{array}$ \\
\hline 56 & $\begin{array}{l}\text { Estagiária } \\
\text { Leila }\end{array}$ & $\begin{array}{c}9 \min 54 s \mathrm{a} \\
9 \min 58 \mathrm{~s}\end{array}$ & $\begin{array}{l}\text { Daí vão dizer: Uh! Ele é } \\
\text { louco? Daí você fala: Não! }\end{array}$ & $\begin{array}{l}\text { Abre a mão direita aberta à } \\
\text { frente do corpo e em seguida } \\
\text { a fecha com o indicador } \\
\text { apontado para cima. }\end{array}$ \\
\hline 57 & $\begin{array}{l}\text { Estagiária } \\
\text { Leila }\end{array}$ & $\begin{array}{l}9 \min 58 \mathrm{~s} a \\
10 \min 01 \mathrm{~s}\end{array}$ & De acordo com o Newton... & $\begin{array}{l}\text { Vira o rosto na direção da TV } \\
\text { e aponta para a mesma e } \\
\text { retorna rapidamente o rosto } \\
\text { para os alunos enquanto } \\
\text { aponta para a TV. }\end{array}$ \\
\hline 58 & $\begin{array}{l}\text { Estagiária } \\
\text { Leila }\end{array}$ & $\begin{array}{c}\text { 10min01s } \\
\text { a } \\
10 \mathrm{~min} 06 \mathrm{~s}\end{array}$ & $\begin{array}{l}\text { Que a inércia... então o } \\
\text { corpo tende a permanecer } \\
\text { em repouso. A menos } \\
\text { que? }\end{array}$ & $\begin{array}{l}\text { Move os dois braços como } \\
\text { fazendo círculos ao lado do } \\
\text { corpo e começa a se mover } \\
\text { entre as carteiras e para } \\
\text { bruscamente e abre os } \\
\text { braços para o lado do corpo } \\
\text { a meia altura e dá paço para } \\
\text { trás, voltando para frente da } \\
\text { classe. }\end{array}$ \\
\hline 59 & $\begin{array}{l}\text { Estagiária } \\
\text { Leila }\end{array}$ & $\begin{array}{c}10 \min 08 \mathrm{~s} \\
\mathrm{a} \\
10 \mathrm{~min} 15 \mathrm{~s}\end{array}$ & $\begin{array}{l}\text { Alguma ação externa... } \\
\text { faça... com que você... } \\
\text { movimente, saia desse } \\
\text { repouso. }\end{array}$ & \\
\hline 60 & $\begin{array}{l}\text { Estagiária } \\
\text { Leila }\end{array}$ & $\begin{array}{c}10 \min 15 \mathrm{~s} \\
\mathrm{a} \\
10 \mathrm{~min} 18 \mathrm{~s}\end{array}$ & $\begin{array}{l}\text { Que que aconteceu aqui } \\
\text { em baixo? }\end{array}$ & 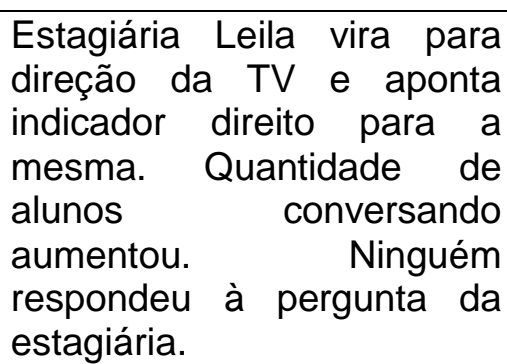 \\
\hline 61 & $\begin{array}{l}\text { Estagiária } \\
\text { Leila }\end{array}$ & $\begin{array}{c}10 \min 18 s \\
a \\
10 \min 25 s\end{array}$ & $\begin{array}{l}\text { O que que acontece? Tava } \\
\text { lá paradinha... }\end{array}$ & $\begin{array}{l}\text { Parte da classe está } \\
\text { conversando. } \\
\text { Estagiária Leila está à frente } \\
\text { da classe e próxima da TV. } \\
\text { Ergue bem alto o braço } \\
\text { direito por alguns segundos } \\
\text { e inicia movimento para o } \\
\text { outro lado da classe e se } \\
\text { coloca entre as carteiras das } \\
\text { duas fileiras centrais. }\end{array}$ \\
\hline
\end{tabular}




\begin{tabular}{|c|c|c|c|c|}
\hline 62 & $\begin{array}{c}\text { Estagiária } \\
\text { Leila }\end{array}$ & $\begin{array}{c}10 \min 29 s \\
a \\
10 \min 34 s\end{array}$ & $\begin{array}{l}\text { O que acontece com você } \\
\text { quando você quando você } \\
\text { está [inaudível], breca? }\end{array}$ & $\begin{array}{l}\text { Estagiária começa a andar } \\
\text { entre as carteiras em direção } \\
\text { ao fundo da sala. Está com } \\
\text { sorriso fixo no rosto. }\end{array}$ \\
\hline 63 & $\begin{array}{c}\text { Estagiária } \\
\text { Leila }\end{array}$ & $\begin{array}{c}10 \min 36 s \\
a \\
10 \min 38 s\end{array}$ & Que que acontece? & $\begin{array}{l}\text { Estagiária está chegando ao } \\
\text { fundo da classe. Ergue a } \\
\text { cabeça para cima e para } \\
\text { baixo várias vezes em } \\
\text { direção variadas, como se } \\
\text { esperasse respostas dos } \\
\text { alunos. }\end{array}$ \\
\hline 64 & $\begin{array}{c}\text { Estagiária } \\
\text { Leila }\end{array}$ & 10min43s & \multicolumn{2}{|c|}{$\begin{array}{l}\text { Estagiária Leila chega ao fundo da classe enquanto estava } \\
\text { questionando os alunos. A partir desse momento, até } \\
10 \text { min58s vários alunos começam a responder. No instante } \\
11 \text { min00s estagiária começa a caminhar para frente da } \\
\text { classe enquanto vai complementando resposta dos alunos } \\
\text { e chega próxima a TV e aponta para mesma e começa a } \\
\text { ler o texto que está na TV, sobre a lei da inércia (até } \\
11 \text { min53s) }\end{array}$} \\
\hline
\end{tabular}




\section{APÊNDICE H: INDICAÇÃO DO CLIMA EMOCIONAL DA CLASSE PELOS ALUNOS E POR PESSOAS EXTERNAS À AULA}

Nossa pesquisa utilizou o Clima Emocional da Aula como heurístico para identificar eventos de alteração emocional (Tobin e Ritchie, 2012; Bellocchi et al., 2013). Como uma forma de validarmos essa forma de medir o clima emocional da aula realizamos uma outra medida em uma turma que não faz parte da escola onde foi realizada a pesquisa. Mais precisamente, em uma aula numa turma de graduação em Física durante a qual os alunos estavam sinalizando o clima emocional com cartões codificados com notas de 1 a 4 (1-muito negativo; 2-negativo; 3-positivo; 4muito positivo), que os alunos apontavam para a câmera.

Ao som de um alarme que tocava a cada 3 minutos, os alunos atribuíam uma nota para o clima emocional que estavam sentindo naquele momento.

Essas placas são codificadas de forma que 0 aluno pode escolher sua nota pelo verso da placa, de forma que nem os demais alunos presentes podem ver a nota atribuída por cada um, nem os leigos que assistiram o vídeo posteriormente e deram suas notas para cada instante que os alunos atribuíram notas durante a aula.

A aula foi filmada e, por meio de um aplicativo de celular Plickers ${ }^{24}$ distribuído gratuitamente, apontado para o vídeo e captamos os valores atribuídos pelos alunos.

Em função de a bateria da filmadora da frente (da qual utilizaríamos a imagem para tomada dos $\mathrm{CE}$ ) ter acabado, tínhamos cerca de uma hora de filmagem, mas com momentos diferentes da aula.

Retiramos também um pequeno trecho em que, ou pelos alunos não terem voltado muito o cartão para a câmera ou porque a luz do teto estava muito próxima da câmera, não obtivemos muitas medidas de CE dos alunos.

Assim, escolhemos três trechos de filmagem de 12 minutos cada um e produzimos três vídeos separados que foram apresentados em três momentos diferentes para três grupos de pessoas leigas: o primeiro grupo de 8 pessoas assistiu aos três vídeos de 12 minutos em um monitor de TV em setembro de 2017 e atribuiu uma nota de 1 a 5 (como fizeram o grupo que havia pontuado sobre o CE da nossa investigação); o segundo grupo de 4 pessoas, em outubro de 2017, recebeu um link dos três vídeos postados no OneDrive e foram instruídos como fariam as atribuições

${ }^{24}$ Disponível em: https://www.plickers.com/cards 
das notas (de 1 a 5); o terceiro grupo de 7 pessoas, assistiu em janeiro de 2018 aos três vídeos em um monitor de TV.

A seguir, apresentamos os gráficos das médias do CE dos alunos dos três vídeos, dos valores atribuídos por eles mesmos durante a aula.
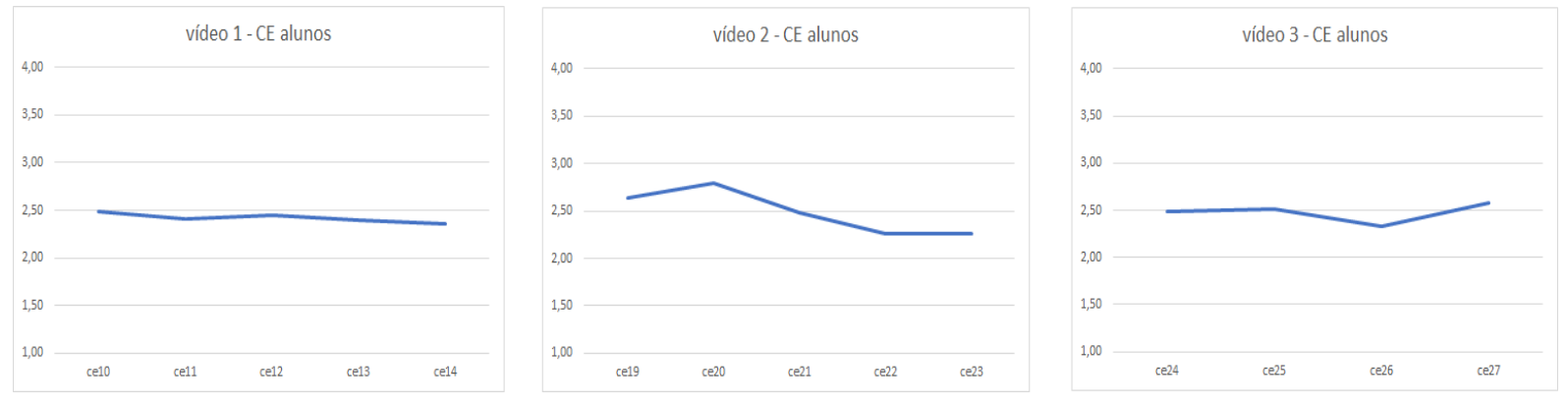

E as médias do CE atribuídos pelos leigos assistindo aos respectivos trechos da aula:

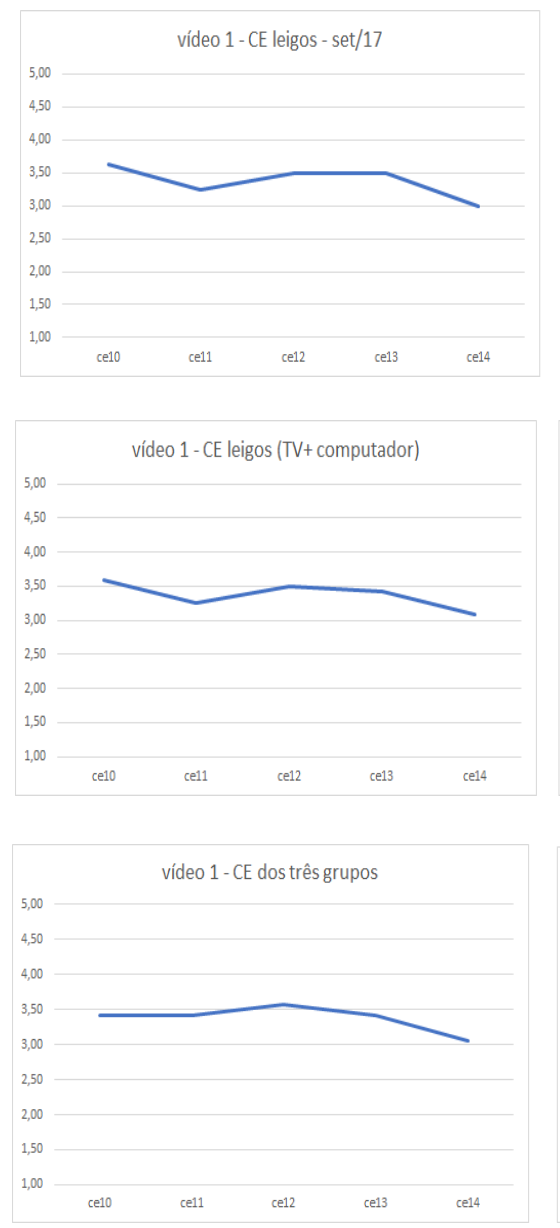

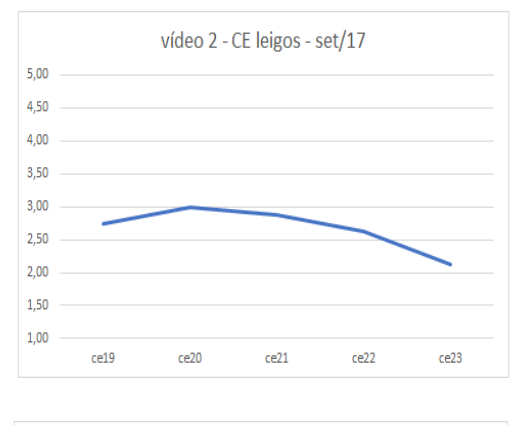

vídeo 2 - CE leigos (TV+ computador)

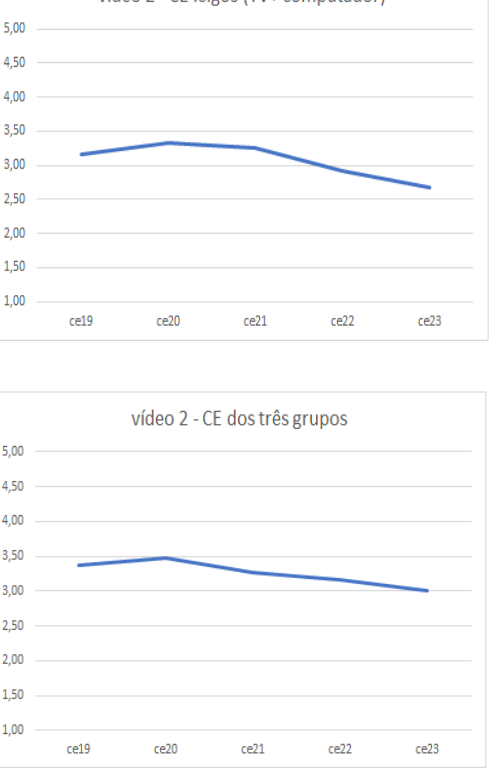

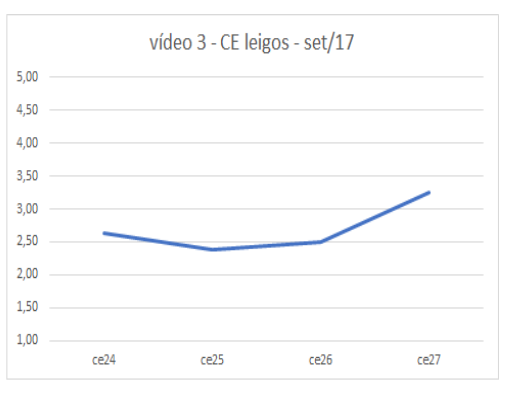

vídeo 3 - CE leigos (TV+ computador)

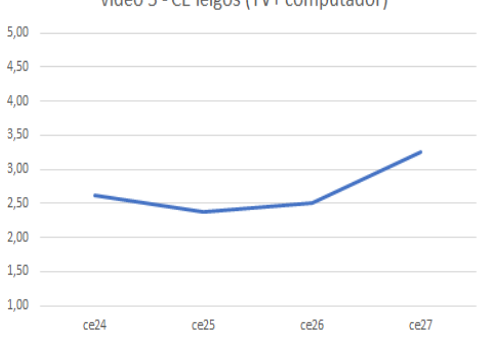

vídeo 3 - CE dos três grupos

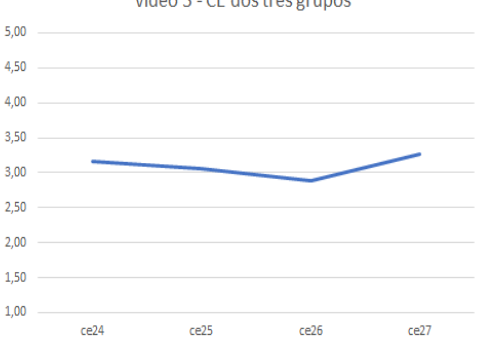

Dos gráficos obtidos podemos perceber que tanto para os alunos quanto para os leigos que avaliaram o CE, não há grandes alterações no CE que possa ser forte candidato a evento nesses trechos de aula. O que por si só já é um fator de 
concordância entre as formar de medir o CE, pois seria discrepante se houvessem momentos de grandes alterações no CE do ponto de vista dos alunos, mas que não houvesse para os leigos, ou vice-versa.

Vale observar que variações nas médias do CE da ordem de 0,5 ou menos são variações muito pequenas, uma vez que o CE está relacionado com muitos fatores e não estamos lidando com medidas exatas. Apesar de as médias parecerem indicar muito bem sobre o clima emocional. Algo análogo à velocidade média das partículas em um gás: podemos ter umas com o dobro da velocidade de outras, mas na média teremos um retrato fiel do estado térmico daquele gás.

No vídeo 1, as médias do CE dos alunos indicam uma fraca tendência de queda que chega a quase ser estável ao longo dos 12 minutos. $\mathrm{E}$ as médias do CE pelos leigos não apresenta discrepância com relação a esse padrão verificado.

Já no vídeo 2, as médias do CE dos alunos apresentaram uma leve tendência de aumento até a segunda medida, que foi seguida por uma queda ao longo do resto do vídeo. Comportamento parecido também ocorreu com as médias do CE pelos leigos, tanto quando tomamos os grupos separadamente quanto quando juntamos as medidas dos três grupos de leigos.

No vídeo 3, as médias do CE dos alunos permaneceram praticamente estáveis até a segunda medida do CE, enquanto a dos leigos apresentou uma leve queda, mas a diferença entre os dois foi muito pequena para considerarmos discrepantes. Por outro lado, no final do vídeo a média do CE dos alunos mostra uma nítida tendência de subida, fato igualmente presente no gráfico das médias do CE apontadas pelos leigos.

Assim, para os propósitos de utilizar as medidas do CE para construir o gráfico das médias e servir como heurístico na busca de eventos, as medidas do CE por leigos assistindo ao vídeo das aulas se mostra plausível, e pertinente para ser utilizado. 